\title{
The Tiguas: Pueblo Indians of Texas
}

Text \& Photography by Bill Wright

Texas
Western
Press

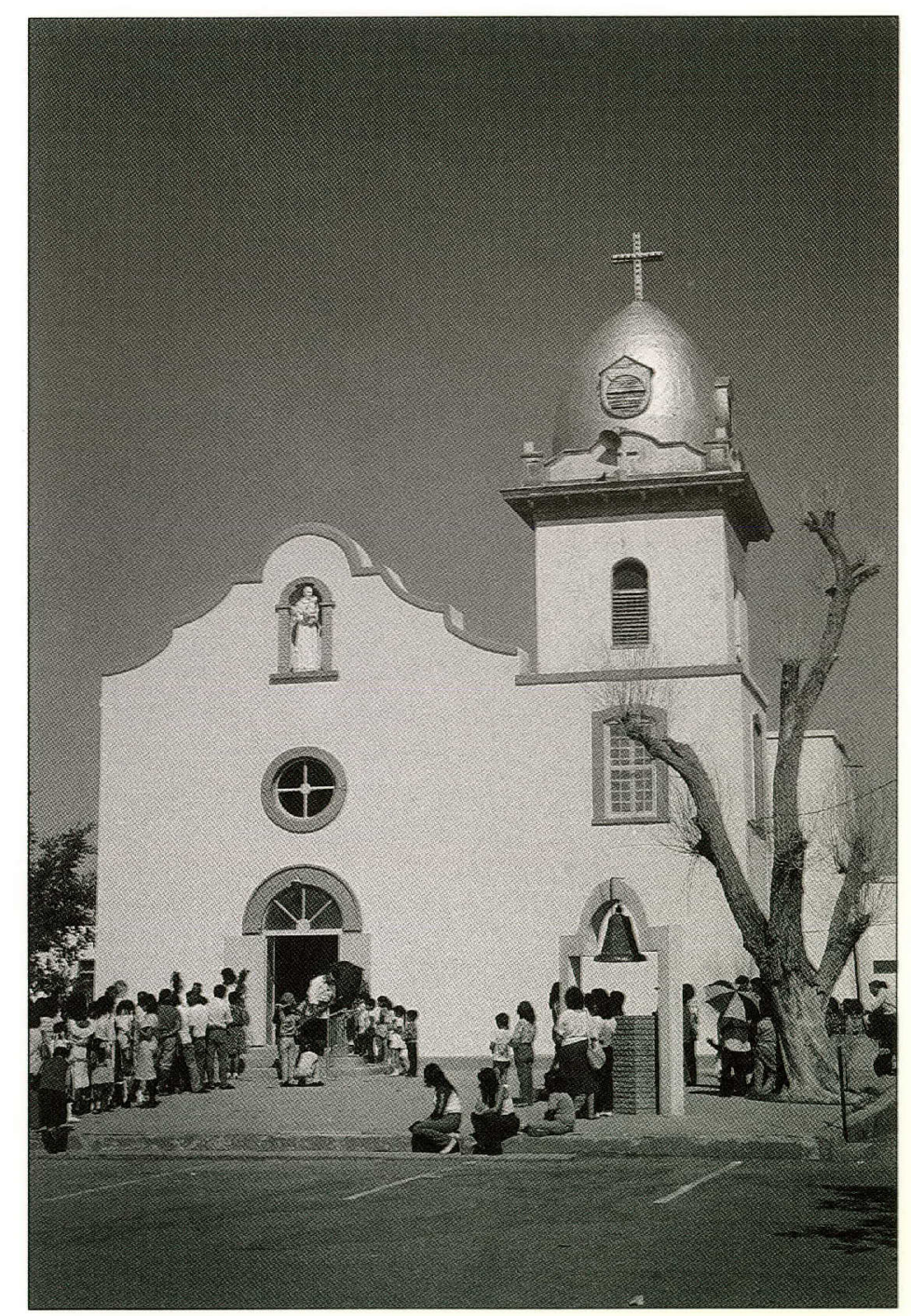


Copyright $(1993$ by Texas Western Press

The University of Texas at El Paso

El Paso, Texas 79968-0633

All rights reserved. No part of this book may be used in any manner without written permission from Texas Western Press, except in the case of brief quotations employed in reviews and similar critical works.

\section{First Edition}

Library of Congress Catalog Card No. 92-062200

ISBN 0-87404-229-1

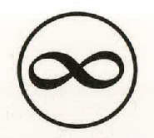

All Texas Western Press books are printed on acid-free paper, meeting the guidelines for permanence and durability of the Committee on Production Guidelines for Book Longevity of the Council on Library Resources. 
To the Tigua Indians of Ysleta del Sur

Masked figures represent Abuelos (grandfathers) ca. 1912 (Courtesy: Arizona State Museum, University of Arizona) ${ }^{l}$

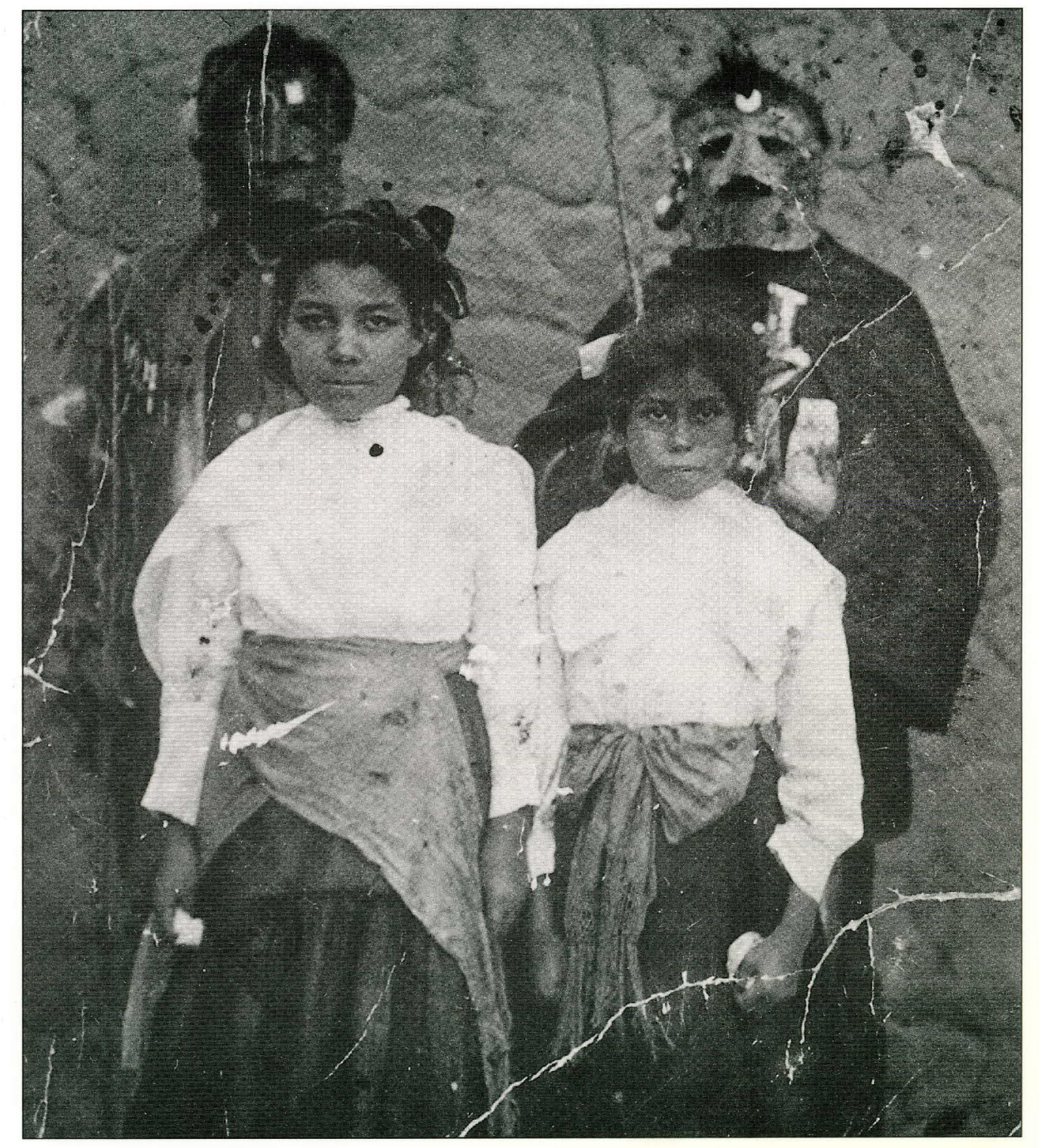




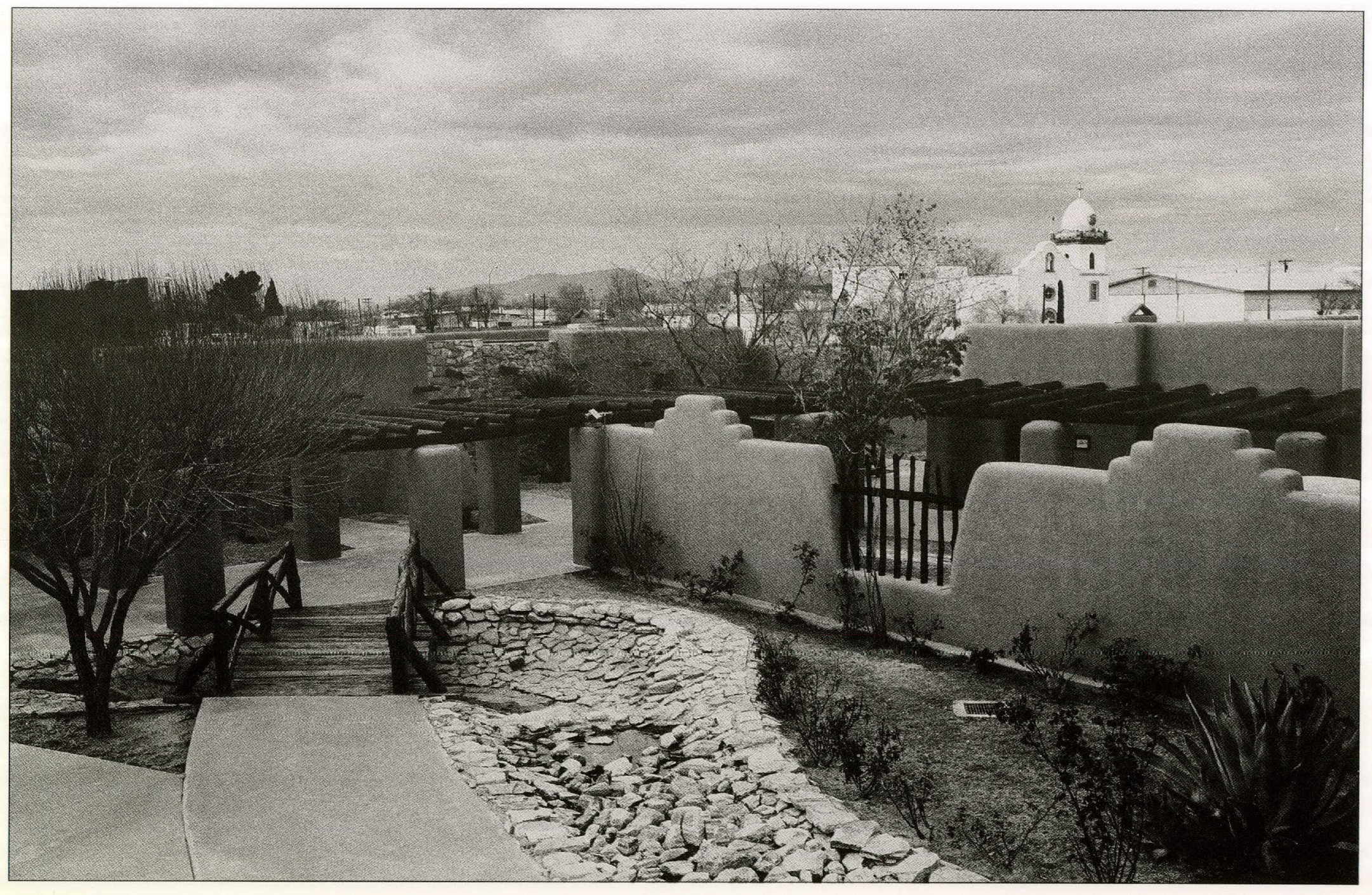




\section{Emergence:A Tigua tribal myth}

The Emergence myth has many varieties, many pueblos, each having their own variety. It is all one concept, one story. Emergence through the soft world, the wet world. All of these worlds had colors. There were animals that helped us get through these worlds; I believe it was a badger that poked a hole through one of the worlds so that we could get on to the next one. There was a yellow world where I believe it started, then came different colored worlds, and I think today, we are in the white world.

In the pueblo dances of New Mexico, the evergreen represents the spruce that our people used to climb to the top of the inner world and to get through the soft dirt into the next world, our present world. The badger pelts that you see hanging out of the men's kilts as they dance represent the animal that assisted us in getting through these worlds.

Danny Archuleta

Ysleta del Sur Pueblo 1992 

Contents

\begin{tabular}{lc} 
Preface & $\mathrm{xi}$ \\
\hline Foreword & $\mathrm{xv}$ \\
\hline History & 1 \\
\hline Beginnings, to 1540 & 3 \\
\hline The Spanish, 1590-1680 & 5 \\
\hline Rebellion, 1680-1836 & 9 \\
\hline The Americans, 1836-1993 & 15 \\
\hline The Place & 29 \\
\hline The People & 43 \\
\hline Ritual & 99 \\
\hline Interview With Tribal Leaders & 135 \\
\hline Tribal Officers of Ysleta del Sur, 1680-1993 & 145 \\
\hline Gourd, (a poem by Leslie Ullman) & 153 \\
\hline Notes on Text & 155 \\
\hline Notes on Historic Photographs & 159
\end{tabular}




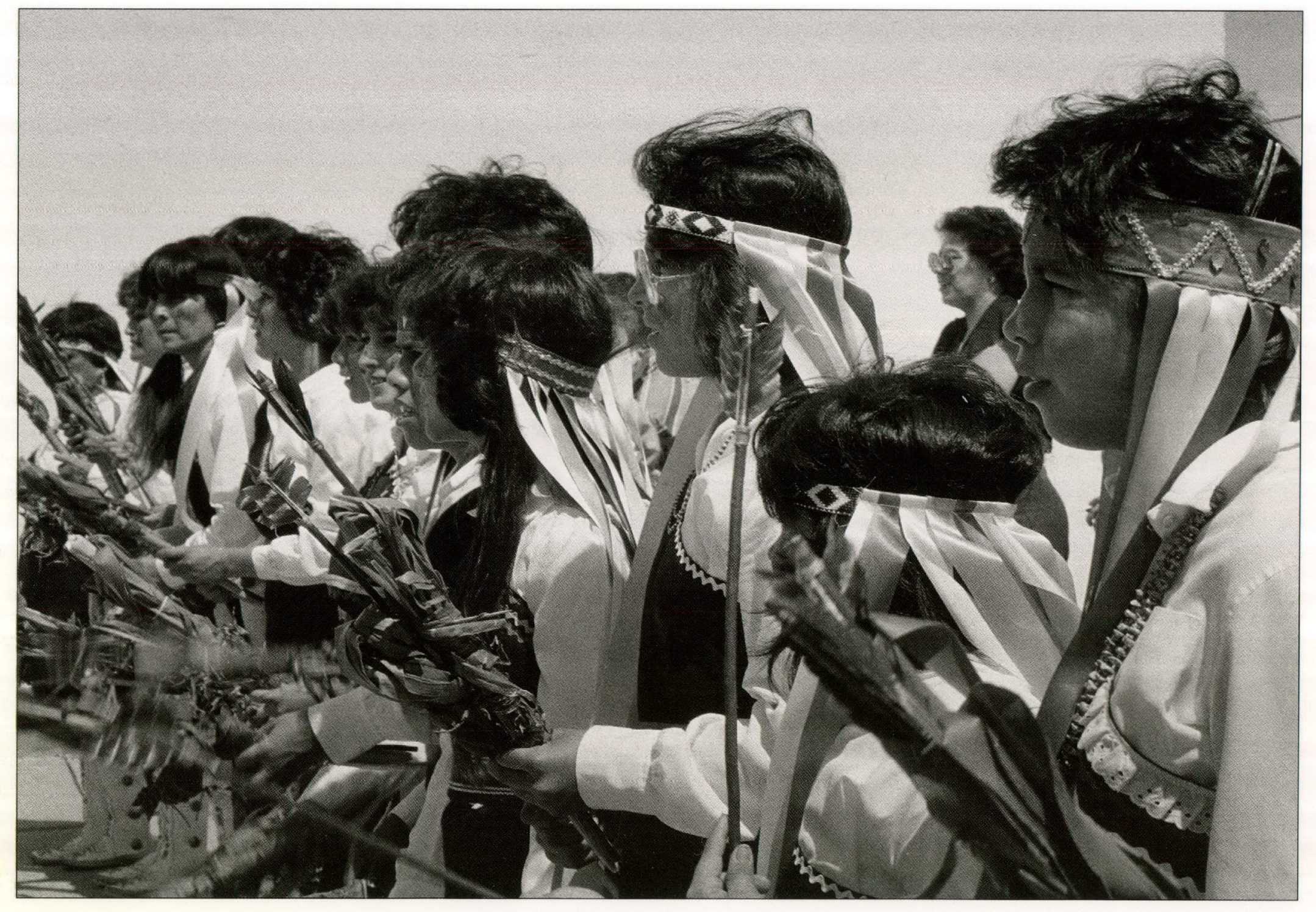


High above the Atlantic on a flight from Kenya where my wife and I had been photographing the Maasai, I wondered why I had gone so far afield to pursue my interest in aboriginal people. Was it the drama of foreign lands and exotic subjects? Why had I not trained my camera and focused my investigations on home folks...those descendants of the first Americans who crossed the land bridge of Beringia and who came to be called "Indians" by mistake.

On that flight I resolved to meet my own countrymen, Native Americans whose ancestors were the first ethnic group to immigrate to the new world. This is how the Tigua project began. In 1986, my log records the first visit to their Ysleta del Sur pueblo and since then, many photographs and tape recordings later, I find that I have learned less than I had hoped, but established friendships far beyond my expectations. If it had not been for the warm acceptance given me by the Tigua people of Ysleta, this book could not have been photographed and written.

Miguel Pedraza Jr., gave me initial permission to work in the pueblo. I will always regret not being able to photograph and interview his father who was ill when I arrived and did not recover. He was wise in the ways of his people and had much to share. Cacique Trinidad Granillo, the spiritual leader of the tribe, welcomed me, and his acceptance was crucial. When he died in 1989, I felt the same sense of loss as I would feel when a wise man of my own community passed into history. His successor, Cacique Enrique Paiz, gave me the same welcome and told me the story of the gourds from which the guajes are made that the dancers shake to repli- 
fields in ages past. I have also been warmly received by the present governor, Julian Granillo, who has assisted me in every way possible.

I would like to thank Ray Apodaca, governor 1990, for his articulate overview of the position of Native Americans in today's culture and their struggle to maintain their identity against the continuing encroachment of western culture.

Johnny Hisa, his wife Rosemary, his daughter and son, have been special friends. Johnny, a man respected by all of the tribe for his intimate knowledge of ritual and tradition, shared with me all that was public information. Together we mourned the death of his son who died during the time I was working with the tribe. Rosemary spent time with me on every occasion I visited the pueblo. Although not a tribal member by blood, she was every bit a member by "heart," and her dedication to the Tigua cultural traditions was unquestioned and always supportive. Priscilla allowed me to photograph her wedding, and I watched Patrick grow from a boy to a fine young man in these past years.

Eva Candelaria helped me find the historic photographs that were necessary for historical context and her family members will always be friends. I cannot say enough about Danny Archuleta, the former education coordinator for the tribe. His sensitivity to tradition, his loyalty to the tribe, and the pain of his personal journey, he has shared with me. Through these years of association, our friendship has become a bond that will never break. How I appreciate Leo Garcia! He took me in as a stranger, fed me in his home, and took me to his church. My interviews with him were minisermons that illuminated my vision and strengthened my own commitments. His son, Kelo, exemplifies all that is good in a young man who lives the spiritual conviction of his life.

There were many others: Joe Sierra, Herminia Silvas, the beautiful Sylvia Apodaca and Rosamaria Silvas...Manny Silvas who told me the stories of the pots and jewelry...Lisa Soto who, beautiful as her image in the book reveals, responded as a teenager would anywhere in the world. And of course, Ramona Paiz. She remains the oldest Tigua at 92, and tolerating my admiration, told me the secret of her agelessness was chopping her own firewood, drawing her own water from the well, and living the simple life.

There were many others who were supportive from outside the tribe: Pat Farr from the University of Texas at El Paso, who shared with me many sources; Nicholas Houser, the anthropologist who first came to learn from the Tiguas and who gave me unlimited access to his materials, and most importantly, who became a good and trusted friend. Tom Diamond, attorney and champion of the rights of Tigua people, was always available, and shared his researches into the Tigua's history and claim to their historic lands.

Archaeologist Rex Gerald provided the comprehensive timeline which I use as the basis of the Tigua chronology, and I wish he could be with us today to receive the recognition he earned with his work on the earliest missions of Texas. The Rev. Ernest J. Burrus, S.J., was an inspiration. His acute and scholarly mind and his knowledge of the early church in southwestern America gave me perspective and moderated my antipathy toward the Spanish. Margaret Blanco shared the work of her father, Cleofas Calleros, who 
was a historian and honorary member of the tribe. El Pasoan Cynthia Farah loaned me valuable research material from her extensive collection. Archaeologists Myles Miller and Debbie Martin assisted with a list of the tribal officers and other information.

I am grateful for the painful introspection caused by my friend and mentor, Tom Southall, of the Amon Carter Museum, who forced me to look beyond the image and who gave me support at every turn; to Anne Tucker of the Museum of Fine Arts in Houston, who told me to quit researching and find a publisher; and to Jean Caslin at the Houston Center for Photography, who spent an evening asking why and making me give a reason. Roy Flukinger, curator, writer, photographer, and anonymous humorist, has guided a legion of documentary photographers into the field and into print. He has been my constant supporter and when the path seemed darkest, he was always there with encouragement.

Hardin-Simmons University Professor Delores Washburn helped with the initial editing of the text and exposed my lack of punctuation skills. Professor Lawrence Clayton prodded me forward when I found the hill of information before me so difficult to climb. I am indebted to Marlene Cohen for exhibiting the photographs in Houston and for the loyal support of Frank and Suzanne Calhoun. Nancy Hamilton, my editor, provided valuable research and additional insight into the history of the tribe and region.

I am deeply thankful for the professionals who took the time to review the drafts of the manuscript and offer their corrections: Ron Tyler with the Texas Historical Association;
Dan Gelo, University of Texas at San Antonio; Leslie Burns and David Haynes of the Institute of Texan Cultures in San Antonio. Archaeologists Curtis Tunnel of the Texas Historical Commission and Douglas Schwartz of the School of American Research in Santa Fe offered important advice on Native American prehistory. Professor Ted Jojola of the University of New Mexico gave me important references and valuable time. Any errors of fact or inference that remain are certainly my responsibility, not theirs.

Although there are many others, I must give special thanks to Pat Jarrett, Beverly Short, and Julie Klump. They are the assistants who kept me organized to the extent possible, who suffered with me my disappointments and shared with me the joys of research, and who spent many lonely hours with my impossible dictation. Finally, my thanks to my loving wife, Alice, who has always been there when I needed her the most. To all of you I will always be grateful.

Bill Wright 


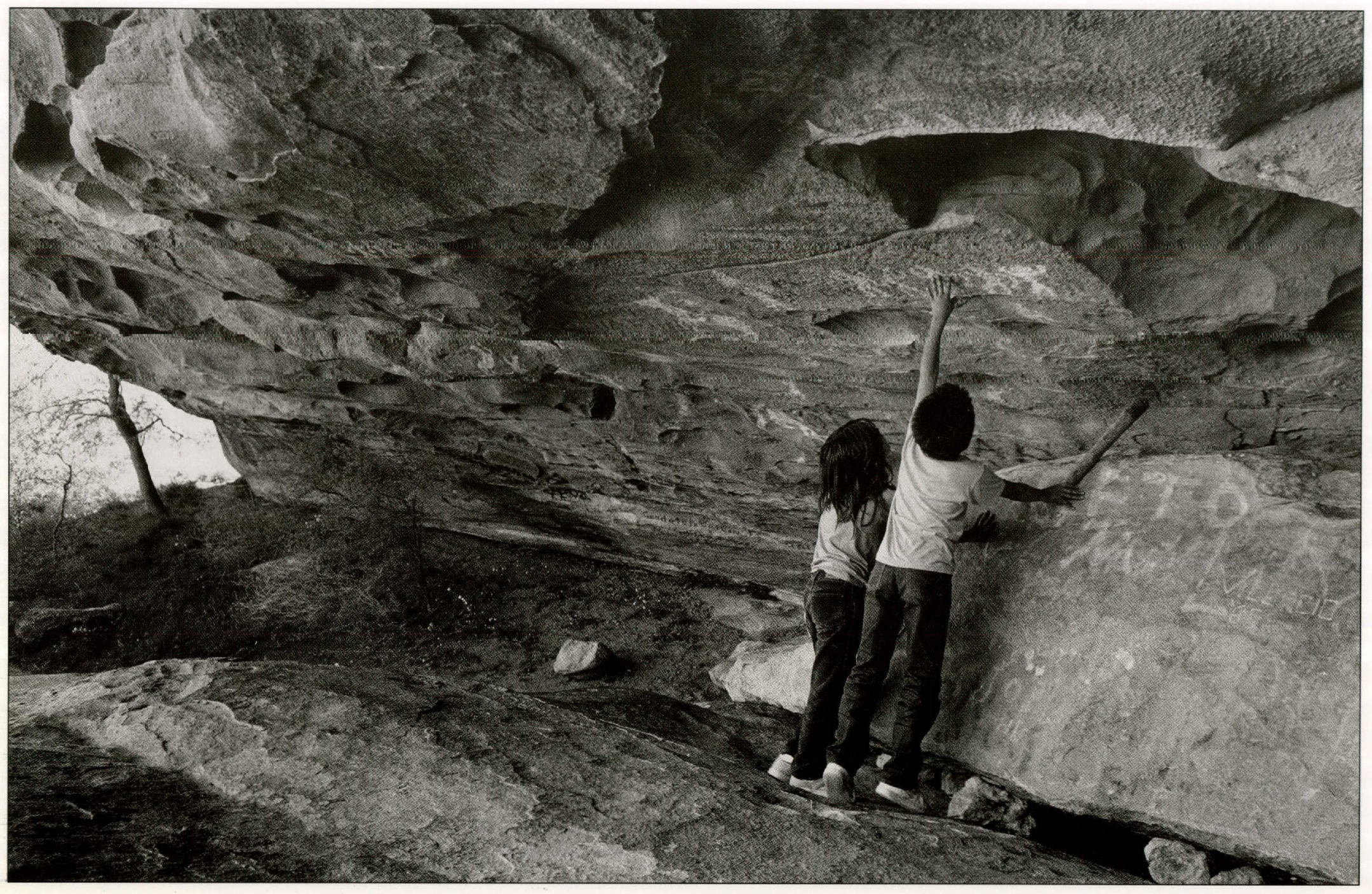


Patrick and Nancy Hisa at Hueco Tanks.
Since the 1680s, when they moved to El Paso del Norte from Isleta Pueblo, the Tigua Indians have lived at the cultural crossroads. Never passive spectators of the traffic around them, the Tiguas accommodated other Puebloan refugees, fought Apaches, and farmed in uneasy coexistence with Hispanic and Anglo colonists. They did, however, grow less and less visible as Indians over the years as they sought to make a living and avoid prejudice, and around 1900 one anthropologist reported dismissively that they had become "Mexicanized." Though the Tiguas proved their aboriginal identity to the federal government and thus secured recognition as an Indian tribe in 1968, there are lingering sentiments that the El Paso Pueblos are simply Hispanics living a lie for the sake of entitlements.

The photos assembled here provide impressive evidence of cultural continuity in the face of such notions. Pictures of the old pueblo at Ysleta show that the architecture there was for some time indistinguishable from that of the New

Mexican villages, and the image of Nestora Piarote with a jar before the adobe buildings is an icon of Pueblo Indian womanhood. The traditional (though modified) government, represented by numerous photos of tribal leaders, has been in continuous operation since before the conquest. A drum collected by the Dutch anthropologist H.F.C. Ten Kate in 1882 appears identical in construction to the main ceremonial drum used today as well as others preserved by Tigua families: these are Puebloan in style, made from a hollowed log with heads on both ends and beat with a relatively short, heavy stick. The large gourd rattles are also still used. One can see that the beehive ovens called hornos now fired to bake Pueblo bread at the tourist center were present around the old pueblo and in the yards of barrio houses. Older Ysletans remember the horno as the obvious sign of an Indian home.

Hunting scenes from Hueco Tanks are remindful that the Tiguas perpetuated ancient patterns of land use at these granite outcrops and in the surrounding desert basin. Rabbits were flushed out of the mesquite tangles in the sandy places, where every creature leaves a trail. (Tomas Silvas remembers that infrequent snow squalls were welcomed because it was even easier to track rabbits in the snow.) Deer hunting was also important, as was a technique for planting corn in the barely perceptible washes that channel rainwater and store moisture below ground level when the flow ceases. Mesquite wood was gathered as the main kind of fuel, and a whole pharmacy of herbal medicines was collected in the desert. These methods were employed by Indians in the region as early as 11,000 years ago, and some Tiguas continued them in this century. It is notable that the Hueco Tanks photos are family portraits, because hunting, gathering, and dry farming were activities centered around, and taught within, the family. The people portrayed here can find the names of their immediate ancestors painted on the rocks of the Tanks amid the pictographic signatures of more ancient hunters.

A wagon once used on hunting trips molders today in the shade beside matriarch Ramona Paiz's adobe house. But even with such tacit reminders of traditional lifeways, the Tiguas make no apology for the elements of Hispanic and Anglo culture they have adopted. Most are bilingual in 
Spanish and English. The baking of wheat bread was introduced to the Tiguas by the Spanish friars even before they migrated to Ysleta, and their modern home cooking style is essentially northern Mexican. Bill Wright's excellent portrait of Priscilla Hisa's wedding shows the Mexican truelove rope or lazo as well as a blanket evoking Indian tradition. Tigua religion is a comfortable blend of Catholicism and native belief; the Indians pray at mass in Spanish and honor the grandfather spirits with tobacco offerings, and their penitentes are lashed with willow boughs, aboriginal symbols of water and life. Ceremonies are regulated according to the church calendar.

Much attention has been given by photographers to the annual feast day celebration for the tribal patron St. Anthony, which is fitting, since this ritual has always been the centerpiece of Tigua cultural life in Texas. Like all effective public rituals, the 13 June feast is an opportunity for participants to express who they are and who they wish to be. Distinct elements of Tigua culture are restudied, refurbished, and displayed for the whole world to see. The ritual promotes a sense of well-being among the dancers, their tribal supporters, and even outsiders; as tribal war captain Marty Silvas put it, this is the one time of year when everyone sets aside business concerns and personal differences and pulls together. The preparatory Walk of the Saints on 4 June is especially important in forging community. The Tiguas walk the streets of Ysleta collecting canned goods and small cash donations in exchange for the brief visit with the saint's statue. Non-Indian residents are happy to show their devotion to the saint and get acquainted with the Indians, and they appreciate receiving an invitation to the free dinner on the feast day. By collecting from non-Indian households and then offering to feed them, the Tiguas ingeniously involve their neighbors in an Indian-managed cycle of redistribution. In this way, the Tiguas assert all at once that they are conscientious members of the larger Ysleta community and a people apart.

Since tribal recognition in 1968, the Tiguas have made a special effort to revive the Indian elements in their culture. This movement was initiated by the Texas Indian Commission to boost tourism and has since gained its own momentum. Sometimes the Tiguas have looked to other Indian communities for ideas. There is a nationwide network of intertribal relations which fosters cultural sharing and revival; Tigua leaders have become involved in it as they travel to administrative conferences. Plains Indian customs dominate in this intertribal milieu - the feathered war bonnet and the intense and colorful Fancy War Dance are appealing to many Indians outside the plains and they suit the expectations of non-Indians raised on John Wayne movies and the like. The Ysleta Indians were also exposed to Plains culture during a 1980s visit from the Kiowas (commemorating a gunfight involving the two tribes) and, in fact, the Tiguas have always been influenced by Plains culture, as Plains-Pueblo trade connections have existed since prehistoric times. But in recent years, sensitive to their own heritage and the criticisms of cultural purists, the Tiguas have gone out of their way to avoid Plains customs in favor of perceived Puebloan ones. Artisans from Isleta, New Mexico, have taught the Tiguas pottery techniques and the 
young people study Pueblo singing, dance, and costuming. The Tiwa language, for all practical purposes dead in Texas, is now being taught to Tigua children in area public schools. All cultures are continually reinterpreting themselves, so there is nothing absolutely artificial about the Tigua renaissance. Former tribal governor Ray Apodaca is fond of saying that "there is no such thing as a pure culture, unless it's a culture that no longer exists."

Like most Indian people, the Tiguas have had to be careful in representing themselves to outsiders, sometimes playing up their Indian identity, but often hiding it. Long-time tribal attorney and advocate Tom Diamond has explained that the Tiguas were conditioned into reticence by decades of discrimination from Hispanics and Anglos. Some members of the present generation recall being mocked during childhood by their non-Indian classmates after they were seen dancing in their traditional outfits. At the same time, it is evident from photos of Tiguas wearing their regalia outside of tribal ceremonies that being Indian was occasionally advantageous. The balancing act is even more apparent when the photos in this volume are considered collectively. For example, a wonderful contrast is provided by Dr. Love's mobile midwives and the Centennial-bound bus-riding Indians. One can study the pictures, paying attention to the subjects' dress and poses, and gain a sense of the range of self-images the Tiguas have had to project.

It is clear that the Indians understand the potential of photography in shaping their public image. Newspaper stories that highlighted the Tigua fight for recognition in the 1950s and 1960s featured memorable photos, such as one of the cacique with the rooster which symbolized his traditional office. In surrendering only certain pictures for reproduction in this volume, the Tiguas have actively helped to influence the view of outsiders. Relatedly, the Tiguas currently ban the photographing of the drum Juanchiro and certain other ritual objects. Such taboos are said to be "traditional," but that does not mean the restrictions have been enforced uniformly over time, for photos of some of the tabooed items already exist, and indeed there is disagreement today among tribe members about the bans. A conservative Tigua might feel that it is the act of revealing a tabooed object, rather than the photo that results, which is harmful. Ironically, the prohibition of a photo becomes the ultimate evidence of Indian conservatism.

Photos are also used by the Tiguas to trace genealogies (an important means of qualifying for tribal membership and entitlements) and to augment their oral history. Today, the young people particularly show a hunger for local knowledge. The present volume will serve them as a comprehensive reference, covering historical and ethnographic details as well as contemporary life. They will also no doubt value the book as an artistic work that mirrors the beauty of their culture.

Whatever use the Tiguas make of this work, it will automatically become part of a five-hundred-year-old tradition of pictorial documentation of American Indians which includes everything from early painting and engravings to picture postcards and television ads. In other words, it is an artifact of non-Indian culture, and it must be evaluated as such. Bill Wright's own photos are technically superb - 
lighting, composition, and print quality are all outstanding. His shots are sympathetic, though not maudlin, and in many cases he creates a sense of intimacy between the viewer and subjects which is absent from anyone else's Tigua photos. Bill's own pictures bespeak his close association with a number of tribe members and his skill as a field researcher; anyone who has done fieldwork knows that the lending of a cherished family picture is the ultimate statement of trust. The shots collected from Tigua families and archives are not only important as a historical extension to Bill's own work, though he has done scholars an important service in searching them out. In the variety of points of view they present romantic, detached, clinical - they work with Bill's images to reveal all the kinds of interactions that Indians have had with each other and with non-Indians. This is an unusual accomplishment for a single pictorial work in the nonIndian tradition.

Like most good things that have happened for the Tiguas, Bill Wright's contribution is long overdue, but it is not too late. It will prove to be timeless. There is always more traffic at the cultural crossroads.

Daniel J. Gelo

Assistant Professor of Anthropology

University of Texas at San Antonio 


\section{History}

BEGINNINGS, TO 1540

THE SPANISH, 1590-1680

REBELLION, 1680-1836

THE AMERICANS, 1836-1993 

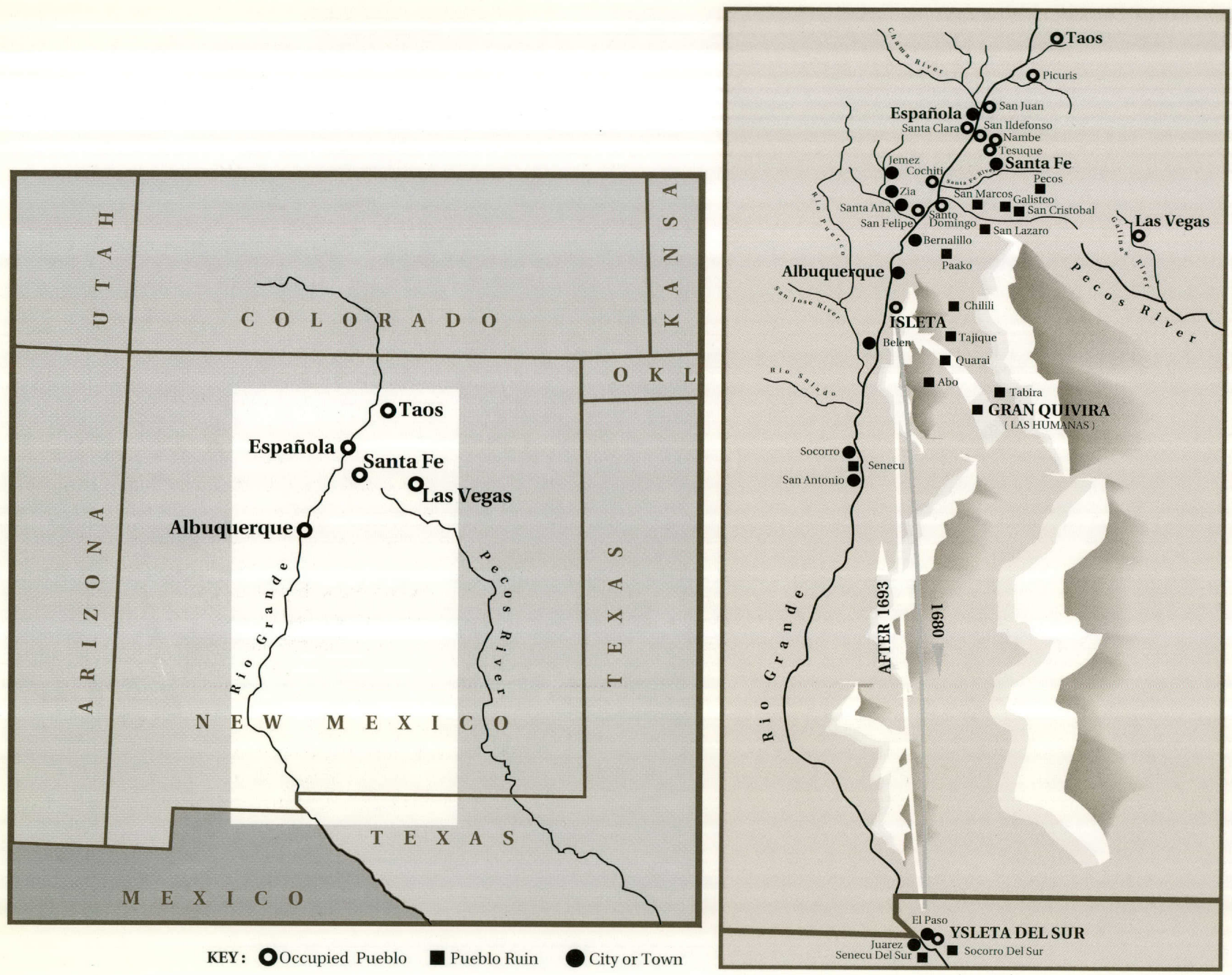

SCALE \begin{tabular}{lllll}
0 & 5 & 10 & 20 & 30 \\
\hline
\end{tabular} 


\section{Beginnings, to 1540}

On 17 September 1540, the Indians of the Tiwa-speaking villages near present-day Albuquerque awoke to startling news from their scouts: The long-awaited meeting with the tall, strange men from the south was at hand.

For years they had listened to stories of the disaster befalling their trading partners in the Valley of Mexico. Then around 1536, their traders returned from the land of the Jumanos speaking of a tall, bearded, light-skinned man and his black companion who healed the sick while traveling westward toward Mexico through what is now Texas. The meeting between the traders of the north, and Álvar Núñez Cabeza de Vaca and Esteban, a black man from Morocco, ${ }^{1}$ was the first recorded encounter between the people of the pueblos and the "Old World."

While the written history of the Tiguas begins with this encounter, noted in Cabeza de Vaca's journal, oral tradition and archaeological evidence push the story of the Tiguas and all Native Americans back to the day when the land stretching from the Arctic to the windswept fjords of Tierra del Fuego was populated only by plants and animals. Archaeologists now believe the first inhabitants of the Americas came across a land bridge connecting Siberia and Alaska sometime between 75,000 and 12,000 years ago. Called Beringia, this land bridge was exposed on and off during the Pleistocene, a cold period when much of the earth's water was held in glacial ice and sea level was lower than today.
The newcomers migrated south through Alaska and beyond. They hunted large animals like the wooly mammoth and mastodon, many of which are now extinct, and left their spearpoints as stone calling cards, announcing themselves to modern researchers. Yet details of their movements are still controversial. The time of arrival has not been set, and some evidence suggests multiple migrations from Asia over thousands of years. Passage south was made either inland through an ice-free corridor nestled between the great ice sheets of the Rocky Mountains and the eastern glaciers, or along the coastline in primitive boats. It seems that succeeding generations spread quickly throughout the northern continent before continuing southward, perhaps arriving at the tip of South America by 8000 B.C. All we really know is that the ancestors of the Tiguas came to the "New World" from Asia sometime in the last 75,000 years, with the earliest undisputed evidence of human occupation - the characteristic fluted points of the Clovis culture - dating from about 12,000 B.C.

By 11,000 B.C. the glaciers began their most recent recession. The environment changed dramatically, many of the large animals disappeared, and the Indians were forced to seek new sources of food and new strategies for survival. They began to rely on small game and gather more plants. Plant gathering gradually led to cultivation among some groups. Indians of south central Mexico were the first to develop agriculture in the Americas, and they apparently 
introduced the science to peoples of the American Southwest. $^{2}$ The southwesterners committed to a settled life as farmers in the desert, building irrigation canals and living in multi-story houses for greater protection. Some of these early apartments still stand. The people of an intermediate southwestern culture that archaeologists call Anasazi,

known from the ruins at Chaco Canyon, New Mexico, and

similar sites, are generally thought to be the ancestors of the Tiguas and other modern Pueblo Indians. ${ }^{3}$ 


\section{The Spanish, 1590-1680}

The meeting of Francisco Vásquez de Coronado's men and the Tigua people had its genesis in the political intrigues of Spain at the end of the fifteenth century. Emboldened by their victory over the Moorish invaders, the royalty of Spain sought to deliver the Christian message to the heathen wherever they might be found. And there was always the need for gold and silver, spices, and other trade goods to defray the costs of the long war and the appetites of the ruling class. The proposal of Columbus to mount an expedition to India finally fell on receptive ears, and his small expedition sailed westward and touched the shores of a land undreamed of by the Europeans of his time.

When Columbus returned from his voyage, he expressed no surprise at encountering people he called "Indians" in the islands of the Caribbean, because he thought he had landed in India, the object of his journey.

He was soon followed by other adventurers and their religious partners, whose first conquests in the New World, both political and theological, were the rich empires of the Aztecs and Incas in Mexico and South America. In time, the legend of golden Cíbola and its riches drew the explorers beyond the settled areas in the Valley of Mexico and north to an encounter with the Tiguas. In 1539 Viceroy Mendoza of Mexico, unable to withstand the lure of the fabled city, authorized an expedition led by Coronado. Prior to this expedition Fray Marcos de Niza, guided by Esteban, previously had journeyed to the edge of the Pueblo country, where they discovered the Zuni Pueblos.
On 17 September 1540 members of the Coronado expedition entered what is now New Mexico and encountered the scattered villages of the Tiguas, which expedition member Pedro de Castañeda, called the province of Tiguex:

Tiguex is a province of twelve pueblos, on the banks of a large and mighty river. Some pueblos are on one bank, some on the other. It is a spacious valley two leagues wide.... They are governed by the counsel of their elders. They build their pueblo houses in common. The women mix the plaster and erect the walls; the men bring the timbers and set them in place. They have no lime, but they mix a mortar made with charcoal ash and dirt, which is almost as good as if it were made with lime. For although the houses are four stories high, their walls are built only half a yard thick....

The unmarried young men serve the pueblo in general. They bring the firewood that is needed and stack it up in the patios of the pueblos, from where the women take it to their homes. These young men live in the estufas, which are located in the patios of the pueblo. They are built underground, either square or round, with pine columns....The floors are paved with large smooth slabs like the baths in Europe. The houses are for the women, the estufas for the men.... In one year they harvest enough for seven years.

Additional reports concerning the Tiguas said they "ate corn, beans and melons, used skins of animals for clothes and made long robes of feathers and cotton." 
Needing food and rest, Coronado's forces camped among the Tiguas, who were initially hospitable. The Spanish, however, soon began to demand more food and supplies than the Indians could reasonably furnish. Relations became strained, and the Spanish resorted to force. When a Spanish soldier raped a Tigua woman, the Indians revolted and a fight ensued. Overwhelmed by the superior force of the Spanish, the Indians surrendered; but upon hearing that some of their number had been burned at the stake in punishment, the Indians rose up again and suffered more than a hundred fatalities.

In the spring of 1541, Coronado left the Tigua villages and traveled eastward in his search for Cíbola. Disappointed, he returned and spent another winter near the villages, now deserted by the Indians, who had withdrawn to the mountains, remembering their costly experience with the Spanish the winter before.

After the departure of Coronado, other expeditions visited the area of the Pueblos and reported the condition of the Indians. In 1581, for example, Hernán Gallegos, notary of the Chamuscado-Rodríguez expedition, described his experience among the Tiguas:

We encountered the settlement where the inhabitants gave us much corn. They showed us many ollas and other earthen ware containers, richly painted and brought quantities of calabashes and beans for us to eat. We took a little so that they should not think we were greedy nor yet receive the impression that we didn't want it; among themselves they consider it dis paraging if one does not accept what is offered. One must take what they give, but after taking it, may throw it away wherever he wishes. Should one throw it to the ground, they will not pick it up though they may be something that they could utilize. On the contrary, they would sooner let the thing rot where it was discarded. This is their practice. Thus, since we understood their custom we took something of what they gave us. Moreover, we did this to get them in the habit of giving freely without being asked. Accordingly, they all brought what they could, the supply of corn, tortillas, corn-flour gruel, calabashes and beans which they brought and such was that enough was left over every day to feed five hundred men. ...The women make tortillas similar to those of New Spain, and tortillas of ground beans too.

Gallegos described the architecture of the pueblos with special insight. He was not content to describe simply the surface appearance of the structures; he delved into the process of construction and the reasons behind it:

In these pueblos, there are also houses of three and fou stories, similar to the ones we had seen before; but the farther one goes into the interior, the larger are the pueblos and the houses and the more numerous the people.

The way they build their houses, which are in blocks, is as follows: They burn the clay, build narrow walls and make adobes for the doorways. The lumber used is pine or willow; and many rounded beams, ten and twelve feet long, are built into the houses. The natives have ladders by means of which they climb into their quarters. These are movable wooden ladders, for when the Indians retire at night, they pull them up to protect themselves against enemies, since they are at war with one another ${ }^{6}$ 
His observations regarding the clothing have been confirmed by other travelers:

These people, like the others, wear clothing. I have decided to describe their attire here because, for barbarians, it is the best that has been found. It is as follows: The men cut their hair short and leave on top, I mean on the crown of their heads, a sort of skull cap formed by their own hair, while others wear their hair long, to the shoulders, as the Indians of New Spain formerly did.

Some adorn themselves with pieces of colored cotton cloth, $3 / 4$ of a vara in length and $2 / 3$ in width, with which they cover their privy parts. Over this they wear, fastened at the shoulders, a blanket of the same material decorated with many figures and colors, which reaches to their knees like the clothes of the Mexicans. Some, in fact most, wear cotton shirts hand-painted and embroidered, that are very pleasing. They use shoes.

Below the waist the women wore cotton skirts, colored and embroidered; and above, a blanket of the same material, figured and adorned like those used by the men. They were adjusted after the fashion of Jewish women, and gird it with embroidered cotton sashes adorned with tassels. They combed their hair, which is worn long.?

Gallegos was also a careful observer of the people and their habits and recorded the most complete description of Tigua domestic life:
These people are handsome and fair skinned. They are very industrious. Only the men attend to the work in the cornfields. The day hardly breaks before they go about with hoes in their hands. The women busy themselves only in the preparation of food, and in making and painting their pottery and chibubites, a pan in which they prepare their bread. These vessels are so excellent and delicate, that the process of manufacture is worth watching; for they equal, and even surpass, the pottery made in Portugal.

The women also make earthen jars for carrying and storing water. These are very large, and are covered with lids of the same material. There are millstones on which the natives grind their corn and other foods. These are similar to the millstones in New Spain except that they are stationary; and the women, if they have daughters, make them do the grinding.

These Indians are very clean people. The men bear burdens, but not the women. The matter of carrying loads, sleeping, eating and sitting is the same of the Mexicans, for both men and women, except that they carry water in a different way. For this, the Indians make and place on their heads a cushion of palm leaves, similar to those used in Old Castile, on top of which they place and carry the water jar. It is all very interesting.

The women part their hair in Spanish style. Some have light hair, which is surprising. The girls do not leave their rooms except when permitted by their parents. They are very obedient. They marry early; judging by what we saw, the woman are given husbands when seventeen years of age. A man has one 
wife and no more. The woman are the ones who spin, sew weave and paint. Some of the women, like the men, bathe frequently. Their baths are as good as those in New Spain....

Their language is very easy to learn. They are the most domestic and industrious people and the best craftsmen found in New Spain. Had we brought along interpreters, some of the natives would have become Christians, because they are very intelligent people and willing to serve.

In 1598 the Indians of New Mexico encountered the expedition that would change their lives forever, for the viceroy of Mexico had given Don Juan de Oñate permission to colonize the northern boundaries of the empire, now the states of Texas and New Mexico. On 24 August 1596, Oñate with 130 men and their families set out, reaching the Rio Grande on 20 April 1598. His party was so exhausted by the rigorous crossing of the Chihuahuan Desert, and grateful that they survived, that a sermon was delivered and a play performed amid general rejoicing. Thus, Oñate may have offered the first "Thanksgiving" and performed the first dramatic production in what is now Texas. ${ }^{9}$ The Indians, however, had little reason to be thankful, for on 30 April, near El Paso, Governor Oñate pronounced his possession of all of New Mexico and Texas for the Spanish King. Continuing on 4 May, he and his party forded the Rio Grande and named the crossing El Paso del Rio del Norte. Rested and nourished, they traveled north, well received by the Indians they encountered. The padres communicated the Catholic faith to the natives as they traveled, and Oñate established Spanish rule over the people. He promulgated the Spanish colonial form of government, causing the Indians to elect a governor and other officers to manage their internal affairs. ${ }^{10}$

Any who resisted the opportunity to serve the Spanish were dealt with harshly. For example, when the inhabitants of Acoma resisted, the governor burned the pueblo and killed many Indians. For those who survived, Oñate imposed a fine of twenty years of forced service and amputated one foot. All females over the age of twelve were also forced into service.

In 1610 Governor Oñate placed his capital in Santa Fe. During the following seven years, the Spanish established eleven missions in New Mexico, and the population of Spanish settlers continued to grow. 


\section{Rebellion, 1680-1836}

Jacal structures similar to those constructed by Tigua Indians after their relocation to Ysleta del Sur in 1680.

(Courtesy: Rio Grande Historical Collections, New Mexico State University Library. $)^{2}$

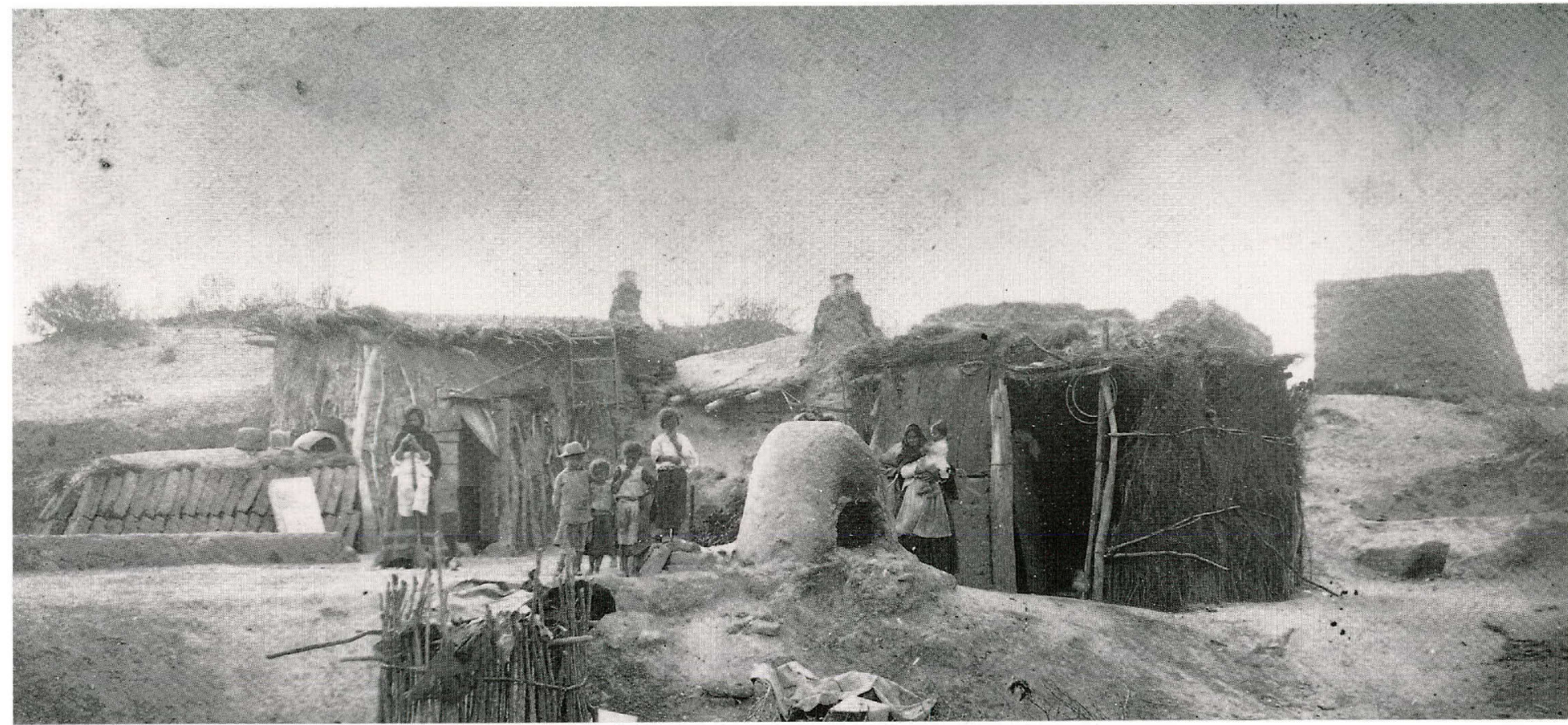

The Spanish occupation produced many immediate changes in the lives of the Indians. While introduced food crops and domesticated animals made their lives easier, smallpox and other contagious illnesses from Europe wiped out thousands, destroying families and whole villages. The Indians adopted the Spanish language and political organization in the pueblos without much resistance. Their spiritual life was slow to change, however; even with severe punishment for backsliding, the Indians continued to worship their traditional gods and spirits, conducting their rituals in secret. Traditional religion was not a casual thing it pervaded the Indians' lives and affected all their actions; thus, attempts by the Spanish friars to eradicate their native beliefs were thoroughly disruptive. Traditional medicine men agitated their people against the padres and bided their time. Another problem was the imposition of a tax collection system called encomienda, along with a forced labor program known as repartimiento. These economic obligations made the Indians virtual slaves. The excessive work demanded by the Spanish left the Indians little time to tend their own fields and so multiplied their suffering.

The Spanish were preoccupied with their own arguments.

Civil and religious authorities constantly bickered over control of the Indians and their work. The conflict grew so 
fervent that when Governor Diego Dionisio de Peñalosa challenged the Franciscans on the issue, they threatened to leave the area. Peñalosa was eventually tried and fined by agents of the Inquisition.

Added to these general troubles was an extensive drought which caused the neighboring Apaches to increase their raiding on the pueblos. Apache attacks became so prevalent that the Salinas pueblos east of the Manzano Mountains were abandoned; the inhabitants migrated westward, some joining the Isleta Tiguas, who spoke the same language. ${ }^{11}$

Since the Pueblos had grown dependent on Spanish protection, they tolerated religious persecution and forced labor until 1680, when they felt strong enough to drive the Spanish out and defend themselves against native raiders. At this point, according to a Spanish census, the Indian population was estimated at 35,000 Christianized natives and an undesignated number of others. There were 2,800 lay Spaniards and 32 Franciscan priests in the area.

On 15 August 1680, the Indians attacked Santa Fe. The Spanish defenders held off the attackers for five days, but on 20 August, the Spanish slipped through the Indian forces and retreated south to Isleta, where other settlers were thought to be gathered. Meanwhile, the southern Spanish thought the Santa Fe contingent lost and began a retreat south toward El Paso del Norte (present Ciudad Juárez; at this time the modern Texas city of El Paso did not exist). Upon finding the Isleta pueblo abandoned, the northern group continued south where they joined the others, along with 317 friendly Tiguas from Isleta, and continuing on, established a temporary settlement in the area of present $\mathrm{El}$ Paso. El Paso del Norte already had a Spanish presence with the Mission of Nuestra Señora de Guadalupe serving the Manso Indians. The Tiguas and two groups of Piros from Socorro and Senecu, New Mexico, were settled in temporary quarters nearby, and the Spanish governor, Antonio de Otermín, began to plan a counterattack.

In 1681 the Spanish force started north in an attempt to recover the pueblos. Governor Otermín's records count 146 in military service and in addition 112 Indians, including 30 Christian Tiguas, under their war captain, Bartolomé Pique. Otermín's attempt was unsuccessful, and by 11 February 1682 the Spaniards had been forced back "with many horses killed and morale shattered...." Historian Vina Walz describes the action:

On the 20th of December 1681, the force sent forward by Otermín returned with pessimistic news, the Tigua pueblo of Isleta had been taken without a shot, but the Indians began to mass and the Spanish feared attack. Eventually it was decided to return to Isleta to incorporate the Christian Indians in the column, burn the pueblo and return to El Paso. Since many of the 500 Isletians, who had originally yielded to the Spanish had escaped to join the rebels, thus being doubly apostate, there were only 385 to be brought back to El Paso. Only 305 of the 385 Tiguas who were captured by Otermín, at Isleta, New Mexico in 1682, were still with the Spaniards when a count was taken shortly before the returning army reached El Paso del Norte. ${ }^{12}$

The defeat of the Spanish forces caused Otermín to reconsider the temporary status of the encampment at $\mathrm{El}$ Paso del Norte. He notified the viceroy on 11 February 1682 
that the settlement would become permanent. The Tigua Indians who returned with him after the abortive attempt at recapture were settled with the Tiguas who had come with the retreat in 1680. Archaeologists are uncertain of this first settlement's location; since the settlements proved to be vulnerable to attack, many were moved closer to the old Mission of Guadalupe in the spring of 1684 for defense.

Between 1681 and 1691 the Spanish erected the original Ysleta mission to serve the Tigua Indian population. Other missions were established at Socorro and Senecu to serve other refugees from the Piro Pueblos of the same name near modern day Socorro, New Mexico (the southern neighbors of the Tiguas). The census of 11 November 1684 records that the pueblo of Corpus Christi de la Isleta had 21 families and 188 persons. A devastating flood swept much of the mission structure away in 1740, but it was rebuilt between 1740 and 1744. The present mission stands on the original foundation and incorporates some of the original wall. Since the meandering of the Rio Grande now places this structure in Texas, the establishment of this mission marks the true beginnings of the state.

The period between the Spanish retreat to El Paso del Norte and the reconquest in 1693 was peaceful for neither the settlers nor the Indians of the pueblos. There were constant threats of revolt from the Mansos and other tribes near El Paso del Norte, and the pueblos of New Mexico had troubles of their own. Bickering between the pueblos and attacks by Apaches, coupled with drought and general disorganization following the departure of the Spanish, made life strained and uncertain. Because of desertions, starvation, and disease, the Tigua population was probably reduced by half. ${ }^{13}$

In 1691 Diego de Vargas became the Spanish governor. Almost immediately there was more conflict with the religious authorities over land. In 1692 the Piro Indians of Socorro asked the governor to order the Ysleta Indians not to encroach upon their land. ${ }^{14}$ This request came in the midst of a power play by Fray Joachín de Hinojosa, who attempted to force Governor Vargas to give the church civil as well as spiritual authority over the Indians and, specifically, to give the church title to the Indian lands to hold in trust for them. In May 1692 the governor did give the church the lands it was devoting to its own use, but refused to grant the church any other civil jurisdiction over the Indians. As a result of this action, the schism between the priest and the governor grew wider and culminated in the governor's revoking the previous grants to the church of the mission property.

The mission for the Tiguas was renamed Mission of Corpus Christi de los Tihuas de Ysleta. According to anthropologist Nicholas Houser, the Vargas grant, even though later revoked, may be the oldest recorded land transaction in the United States.

In 1693 Governor Vargas succeeded in reconquering the pueblos of the north, and the Indians' short period of independence came to an end. After recapturing the pueblos, the Spanish demonstrated that they had learned one lesson: they eliminated the hated practice of encomienda. In many pueblos, they also permitted the Indians to continue their native ceremonial dances and religious practices in addition to those of their new Catholic faith. Thus, the Tigua leadership of Ysleta remained friendly with the Spanish, perhaps from necessity, and the Tigua governor assisted in 
apprising the settlers of possible trouble. Indeed, the Tigua braves proved so effective as fighters that the Spanish commanders utilized their services at every opportunity.

After a period of years, the old Isleta pueblo near Albuquerque was reinhabited by a portion of the Tiguas who had fled to El Paso del Norte and to other areas. The mission was given the name San Agustín. ${ }^{15}$ The Tiguas who remained in El Paso del Norte and settled at Ysleta continued to assist the Spanish and established fertile farms of corn and vineyards of grapes, which amazed travelers to the area.

A map of Kino's drawn in 1724 from an earlier 1710 version shows Ysleta, Senecu, and Socorro all south of the Rio Grande. ${ }^{16}$

Reports from various travelers indicate that the river continued to change course, the villages often being reported on what is now the Mexican side of the river. By 1713 the property allocated to the Indians was enlarged by a royal order to one league in each cardinal direction from the door of the church. When Brigadier General Don Pedro de Rivera visited Ysleta, it, Senecu, Socorro, and San Lorenzo were all on the north bank that is the American side today. The general was impressed by the productivity and attractiveness of the region:

There is a spacious valley dotted with farms, where they plant wheat, corn, beans and all kinds of vegetables as well as a quantity of vineyards which yield fruit of superior quality to that of Parras. The natural fertility of the land is improved by the number of irrigation ditches, which carry water from the said Rio del Norte making the farms independent of droughts. ${ }^{17}$

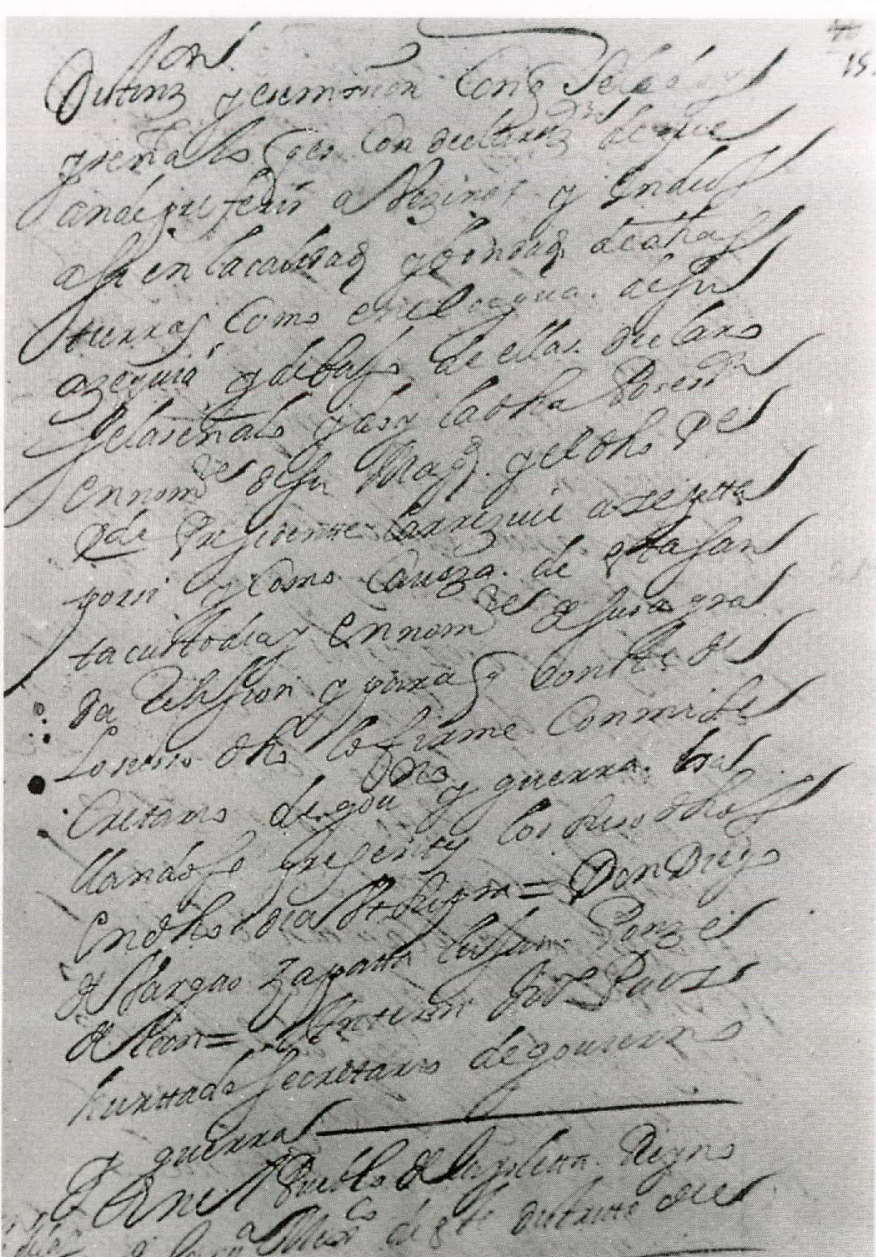

Reproduction of a page from the three hundred-year-old Ysleta Mission "grant" giving the possession of the church, convent, and garden to the Franciscans by the governor of New Mexico, Don Diego de Vargas Zapata Luján Ponce de León dated 19 May 1692.

(Courtesy: Archivo General de la Nación (Mexico City) Historia 37:5.33 
Nestora Piarote standing before Alderete-Candelaria House which has been restored and serves as the

Wyngs Restaurant at the Tigua Indian Tribal Headquarters. (Courtesy: Otis A. Aultman Collection, El Paso Public Library. $)^{4}$

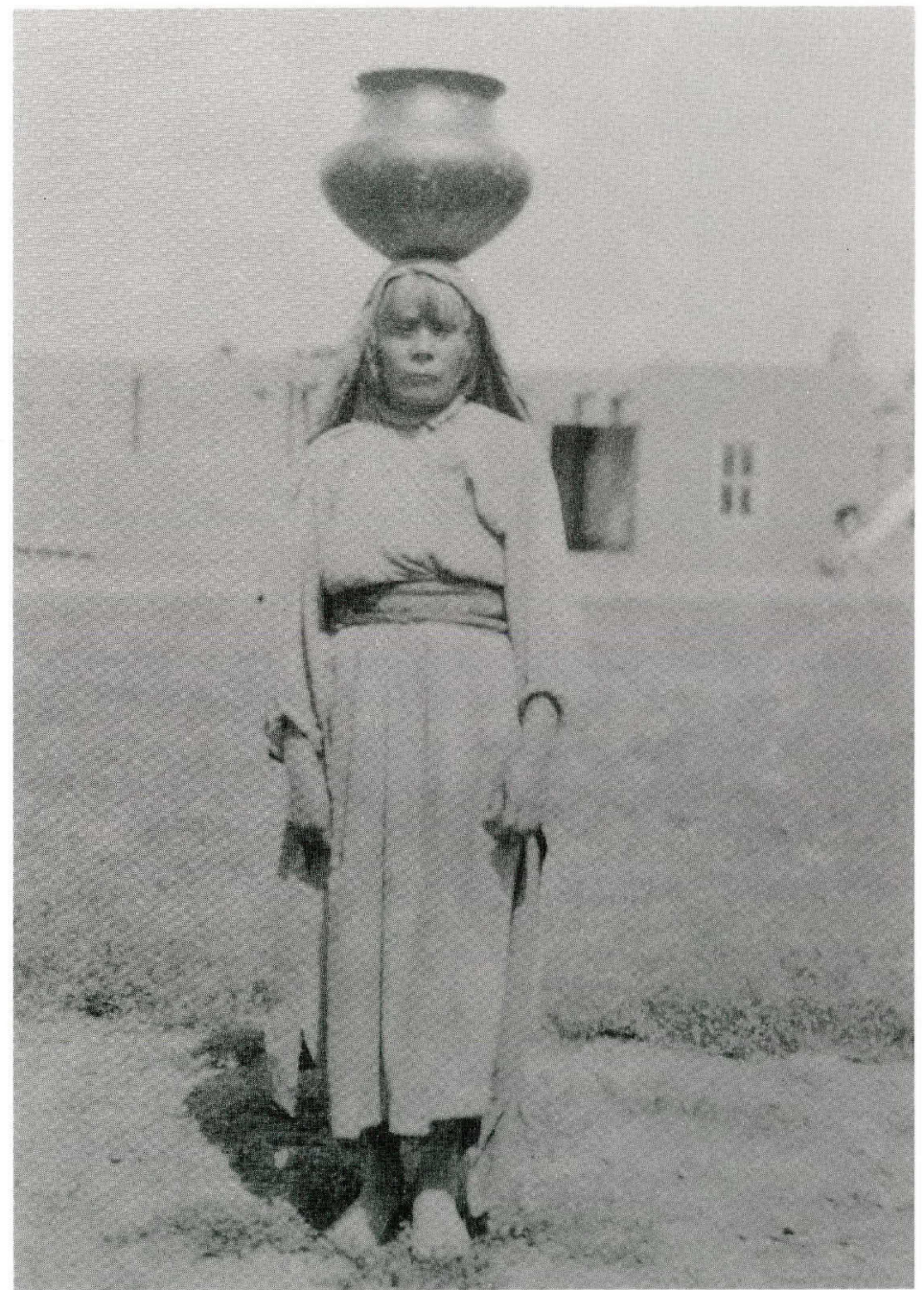

The population of the Tigua tribe at Ysleta was recorded during the census of 1749, showing Ysleta with fifty-four Spanish, five hundred Tiguas, and Mariano López as the resident padre. The Tiguas applied themselves to the cultivation of the land under the protection of the Spanish and continued to serve the padres in various capacities. Fray Manuel San Juan Nepomuceno y Trigro, in a letter dated 1754, describes the cultivation practices:

The Indians of San Antonio de Ysleta have their gardens adorned with beautiful grape vines, peach trees, apple trees, and good vegetables and the garden of the convent imitates them in providing delight to the eyes and satisfaction to the taste. All the cultivation is due to the annual presence of a gardener, provided by the sons [of the mission], who come to the convent every week with the boys needed for the daily cleansing of the cells; they also provide the other workers- a bell ringer, porter, cook, two sacristans, and the Indian women needed to grind the wheat.

Since they pay no obligations, they are prompt and willing to do all things. ${ }^{18}$

Satisfactory conditions continued for the Spanish settlers and the Indians. Bishop Pedro Tamarón visited El Paso in 1760. He described the effective farming capability of the

Tiguas and the problems with the river:

This ditch is subdivided into others which run through broad plains irrigating them. By this means, they maintain a 
large number of vineyards from which they make superb wines. Even better than those from Barras and also brandy, but not as much.

They grow wheat, maize, and other grains as well as fruit trees, apples, pears, peaches, and figs. It's a delightful country in the summer.

This settlement suffers a great deal of trouble caused by the river. Every year the freshet carries away the conduit they make to drain it of its waters. The flood season lasts the months of May, June, and July. ${ }^{19}$

With the settled conditions that prevailed, the Tiguas began to prosper. The census of 1788 lists a population of 773 persons from 166 families. Historian Dr. W. H.

Timmons describes the Spanish Census:

Tigua names were listed for the first time in the El Paso area in the Spanish census of 1784, and again in the census of 1787 . According to Professor Rick Hendricks' research, there were 63 Tigua families, or 195 persons, in the 1787 census, indicating a significant decline in the Tigua population and in the size of the Tigua family. Thus, H. H. Bancroft's reference in his North Mexican States and Texas (I:658, n. 42) to a terrible epidemic in 1784-1785 that took 1,200 lives in the El Paso area, most of which were probably Indians, is worthy of note. In the Spanish census for Ysleta in 1790, 22 families, or 115 persons are designated “español"; 18 families, or 87 persons, are labeled "mestizo"; and 55 families, or 191 persons, are listed as Tiguas, for a total of 95 families, or 391 persons, residing in the Ysleta pueblo. ${ }^{20}$
Even though the climate was generally favorable and relations with the Spanish tolerable, there were still the warring Apaches to contend with, but the Tiguas continued to assist the Spanish. After the Mexican Revolution of 18101821, they became citizens of Mexico. The new status as Mexican citizens had little effect on the life of the Tiguas, nor did the 1836 Texas Revolution. More important was the continued changing of the Rio Grande channel. Ysleta became an island in 1831 or 1832, then in 1849 the river shifted to the south, again placing Ysleta and the other settlements on the side of the future United States.

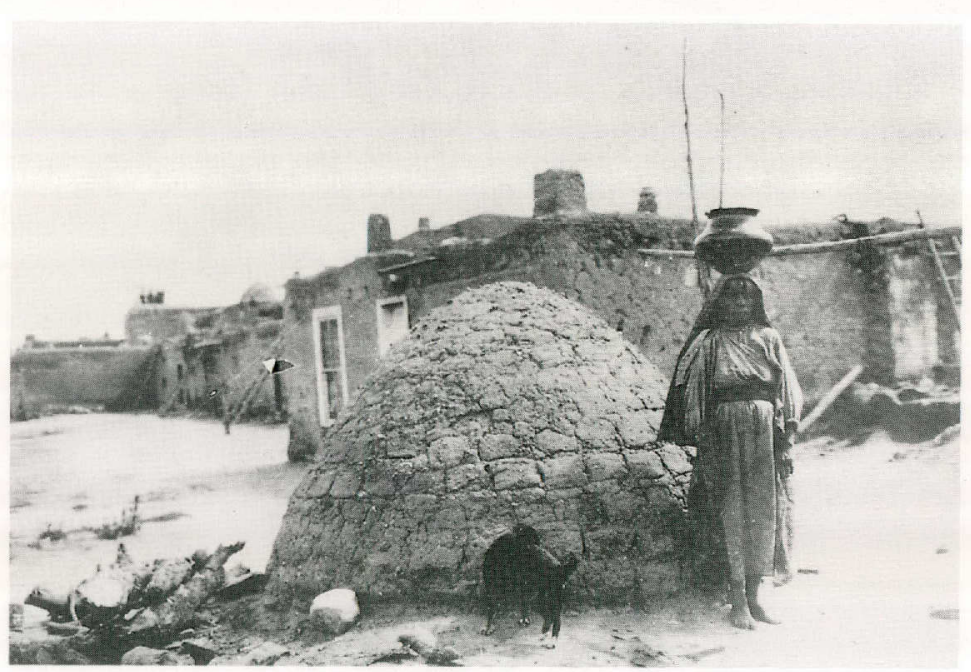

Nestora Piarote standing before horno in Old Pueblo, Ysleta del Sur. ca. 1870. (Courtesy: Otis A. Aultman Collection, El Paso Public Library. $)^{5}$ 
Juana Márquez, daughter

of the Tigua Cacique,

Domingo Márquez, married Ben Dowell, the first mayor of El Paso, in 1852.

(Courtesy: Robert Phillips.) ${ }^{7}$
Wenceslao Granillo,

Tigua scout for the U. S. Cavalry. Ca. 1880. (Courtesy: Miguel Pedraza.) ${ }^{6}$
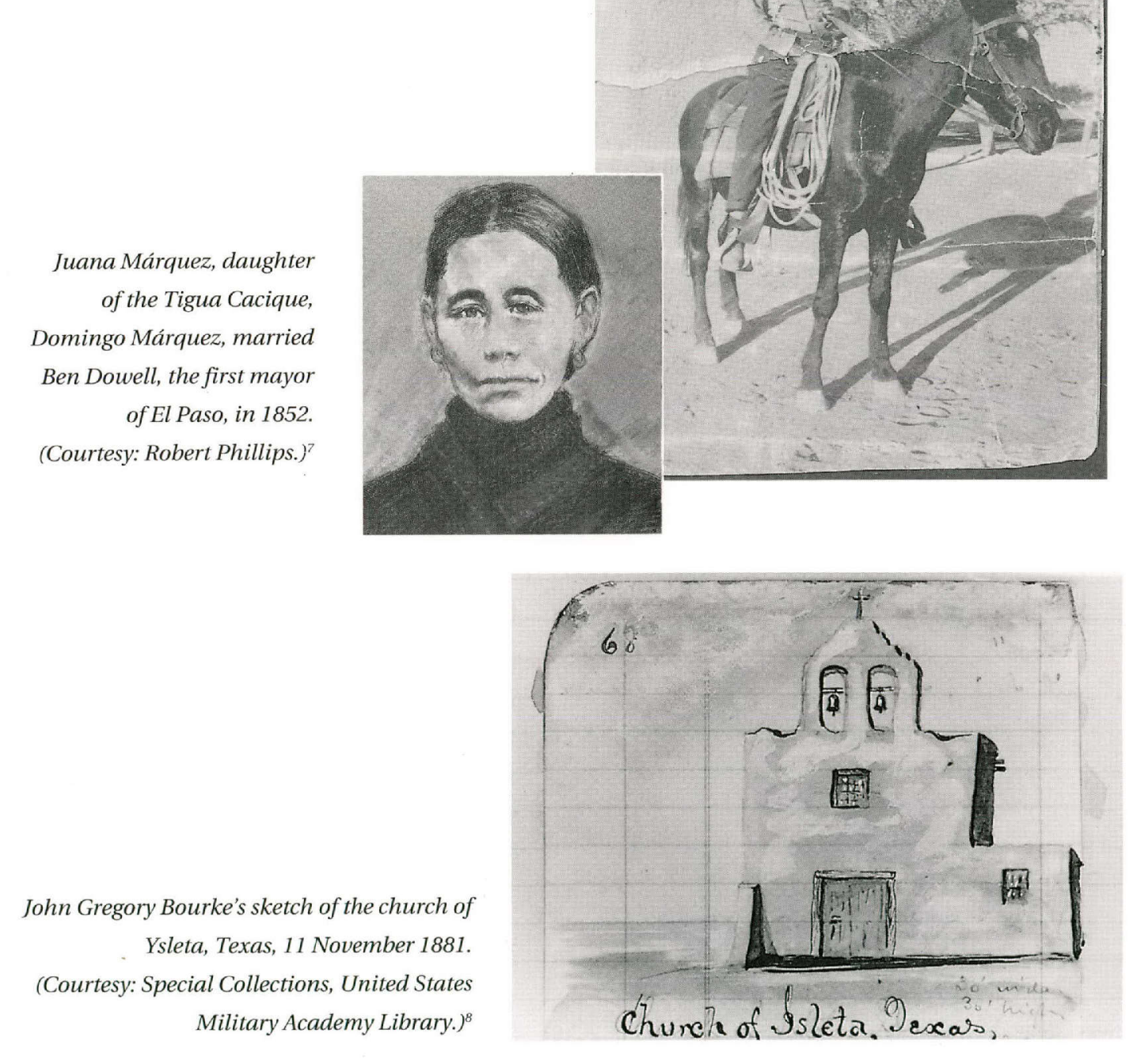

\section{TheAmericans, 1836-1993}

Texas joined the Union in 1845 with uncertain western boundaries. The 1848 Treaty of Guadalupe Hidalgo fixed the U.S.- Mexico boundary in the middle of the Rio Grande channel, and the Organic Act of 1850 set the present limits of Texas and New Mexico, making Ysleta, along with the entire Trans-Pecos region, part of Texas. But a decade later Ysleta lay in the Confederacy, with unfortunate consequences for the Tiguas, since it was during the Civil War that Congress addressed the status of the Rio Grande Pueblos. President Abraham Lincoln invited the tribal governors from New Mexico Territory to Washington and presented them with canes (symbols of authority) and official documents, and ultimately granted them land patents. Because they lived in a Confederate state, the Tiguas were not included, and thus failed to gain a reservation.

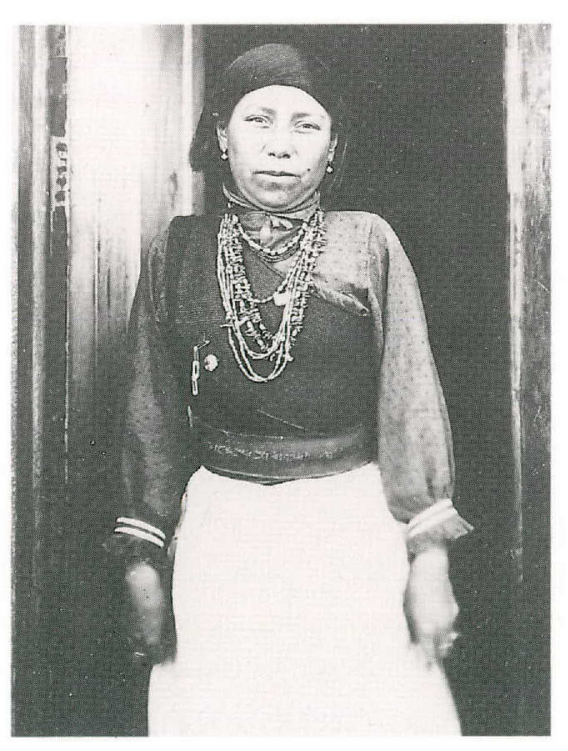

Rufina Durán, wife of former cacique José María Durán.

(Courtesy: Otis A. Aultman Collection, El Paso Public Library. $)^{9}$ 
The Tiguas lost some of their lands under Spanish and Mexican rule, but the final blow came in 1871 when unscrupulous Anglo speculators talked the Texas Legislature into enacting a law incorporating the city of Ysleta. It was no accident that the city boundaries coincided with the original Ysleta grant given to the Indians by the Spanish and theretofore recognized by the State of Texas under the Relinquishment Act of 1854 . The newly created city was the largest in the state in land area, containing thirty-six square miles. It had the power to deed tracts to non-Indians without compensating the Tiguas, and it imposed taxes that the Indians could not pay as an excuse to confiscate their property. In 1874 , the incorporation was found to be illegal under the state constitution, and the city was dissolved. Land transactions that occurred during the interim were not revoked, however, and the Indians were effectively removed from possession of their grant and aboriginal holdings. ${ }^{21}$

Another crisis adversely affected the Tiguas in 1877. For years the Indians had secured salt from isolated dry lakes near the Guadalupe Mountains to preserve their food, to use for seasoning, and to trade for other merchandise. Judge Charles Howard, a local speculator, a scheming priest named Antonio Borajo, and others attempted to secure control of the salt flats and deny the Indians access to them. War broke out and Howard was killed, but the Indians ultimately were cut off from the flats by the Anglo settlers in El Paso. ${ }^{22}$

Problems with the Apaches continued. Several Tiguas were recruited as scouts for the Texas Ranger unit headquartered at Ysleta under Captain George W. Baylor. Tiguas also scouted for the Tenth U.S. Cavalry. Simon Olguín and four other Tiguas were with Second Lieutenant Stephen Crosby Mills' detachment when it was attacked by a small party of Apaches that had escaped the destruction of Victorio's band. Against Olguín's advice, the detachment camped for the night at Paso Viejo; in the morning, as

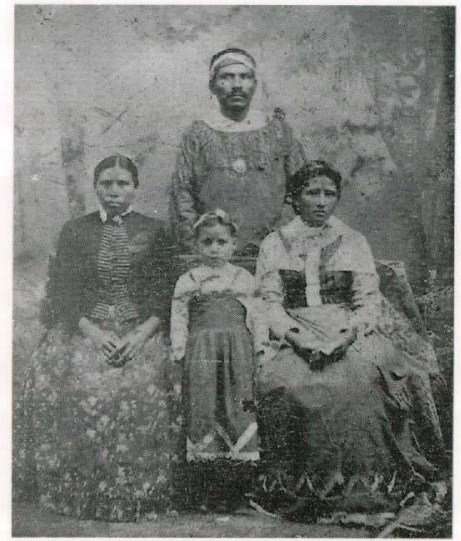

Pabla Márquez Gonzales seated on left; child is Delfina Gonzales. Others are unidentified. Tintype ca. 1892. (Courtesy: Rose Hernandez.) the unit was preparing to mount, the Apaches struck.

Olguín and several regulars were killed in the first round of fire. The soldiers fled but the Tiguas took the rocks and eventually drove off the attackers and recovered their dead. ${ }^{23}$

For the most part, the Tiguas continued to live with little change in their daily lives. They farmed and hunted, blending into the resident Hispanic population. In 1881, John G. Bourke, a pioneer ethnologist with the United States Army, described a Tigua household:

I saw a shield, bows, arrows, guns, and a bundle of eagle feathers and a pair of wooden spurs, hanging from the rafters. But beyond these, nothing whatever to lead me to suspect I wasn't in the house of an humble and industrious family of Mexicans. ${ }^{24}$ 


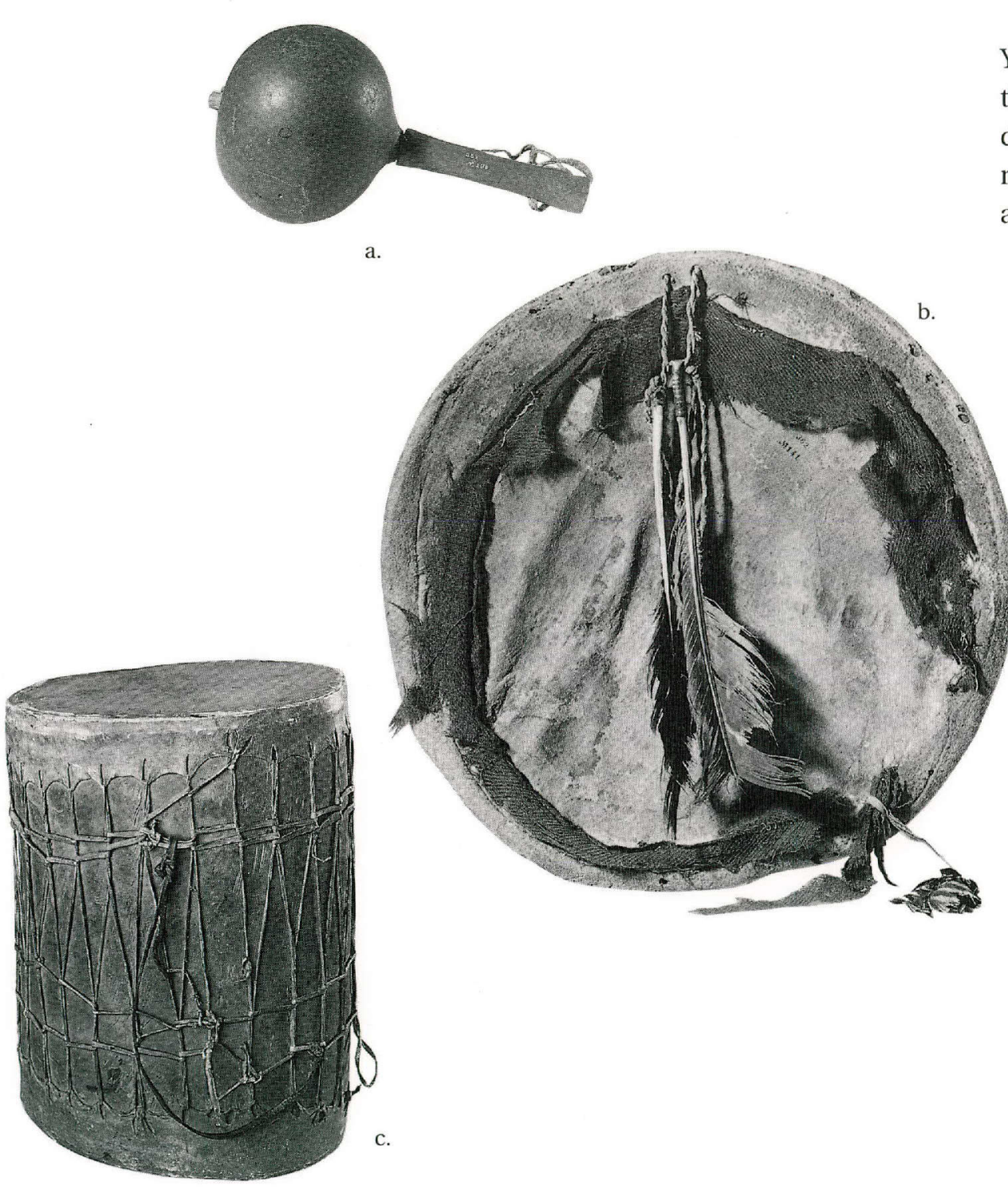

Dr. H. F. C. Ten Kate, a Dutch anthropologist, visited Ysleta the following year. He recorded that the governor of the tribe at the time was José María Durán and that the tribal dancers decorated their faces with red paint. Ten Kate returned to Holland with artifacts of the tribe and wrote an account of his experiences. ${ }^{25}$

a. Gourd rattle (guaje) acquired by Dutch ethnologist H. F. C. Ten Kate during his expedition to the American Southwest in 1882.

(Courtesy: Rijksmuseum voor Volkenkunde, Leiden, Netherlands. $)^{n}$

b. Tigua shield (gwijer).

(Courtesy: Rijksmuseum voor Volkenkunde, Leiden, Netherlands. $)^{12}$

c. Tigua drum (pohojeth).

(Courtesy: Rijksmuseum voor Volkenkunde, Leiden, Netherlands. (23 $^{23}$

d. Tigua moccasins made of deer or antelope skin.

Courtesy: Rijksmuseum voor Volkenkunde, Leiden, Netherlands. $)^{\text {td }}$

d.

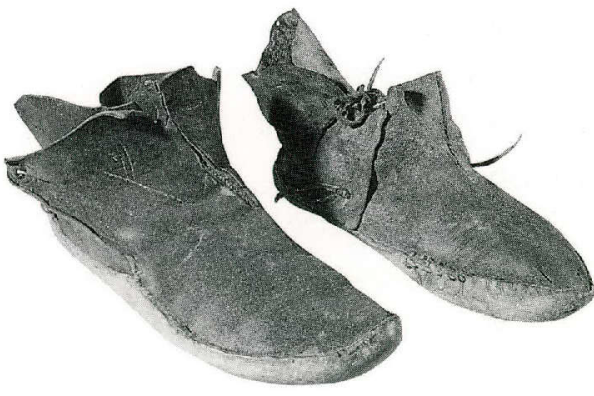


The Tiguas at Ysleta continued to live in close communion with their Hispanic neighbors. When social disturbances threatened to disrupt their traditional ceremonies, some members of the tribe migrated to the Mesilla Valley and established a Tigua presence there. Today, many members of the tribe recognize relatives among the Indian population of Tortugas and until recently, joined with them in conducting the traditional rabbit hunt. ${ }^{26}$ Other groups may have moved to Zaragosa,

Mexico. $^{27}$

By 1890 , the mission administration was changed again. The Rev. Paul Baudrillard, a French priest, displeased the Indians, who chased him from the mission. They seized the sacred vessels and sold them to a Juárez jeweler, but the vessels were later recovered. Bishop Edward J. Dunne of Dallas secured the services of the Jesuits in 1894, satisfying the Tiguas. ${ }^{28}$

At the beginning of the twentieth century, the modern world began to encroach upon the historic Tigua culture. Prior to this time, the Indians generally kept to themselves, practiced their traditional customs, and seldom intermarried with the local Hispanic population. Perhaps sensing that it was time to define themselves, in 1895 they adopted a

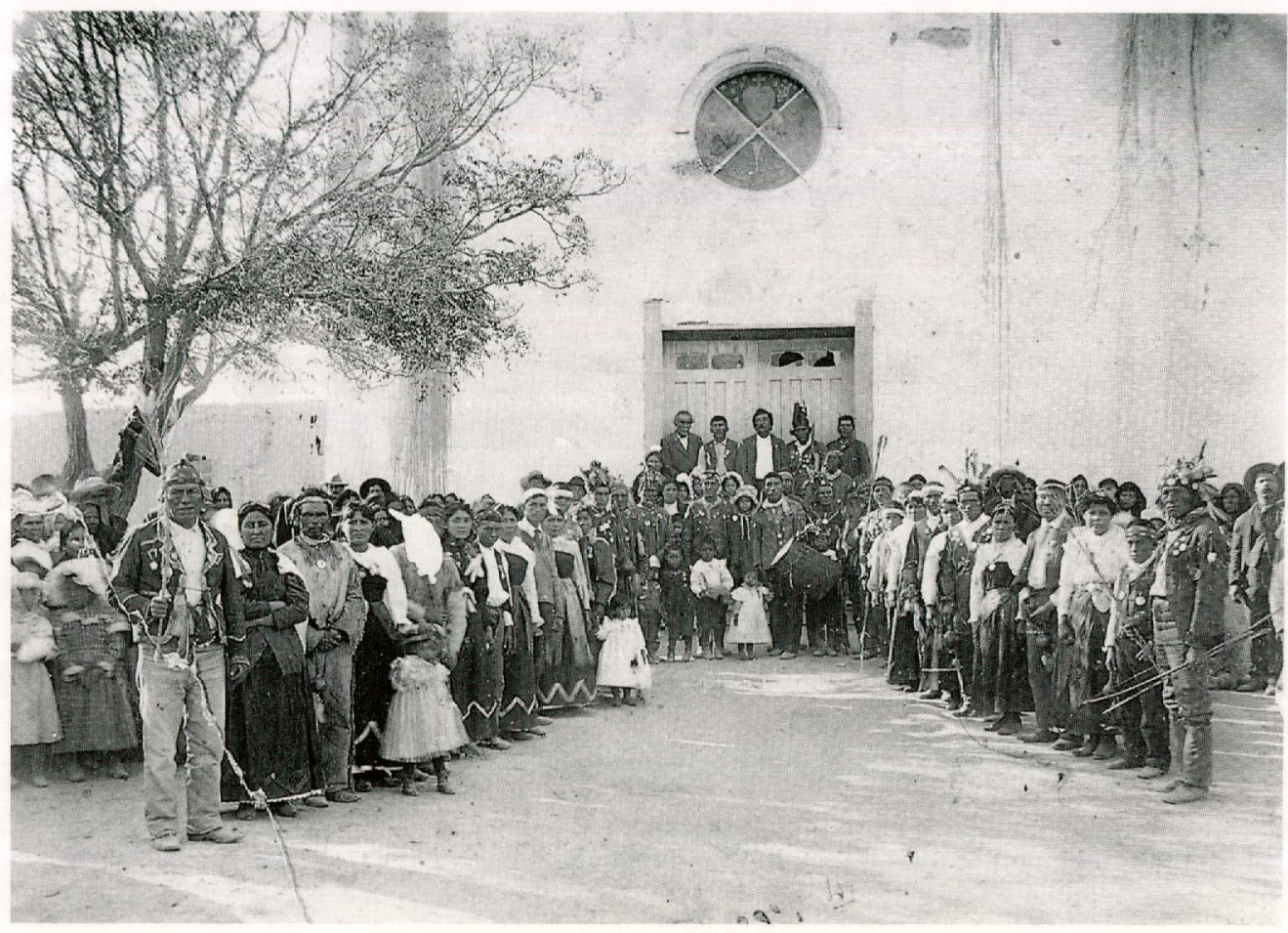

constitution that spelled out the tribal organization and explained the duties of tribal officers. They had the document sealed and signed by a notary.

In 1907, anthropologist J. W. Fewkes made note of the condition of the tribe, reporting that the Indian houses, arranged around a central plaza, were constructed of vertically placed wooden branches chinked with mud, as in the early day jacales. Claiming to have seen the aforementioned constitution, he listed the officers of the tribe and
Celebrants at the Feast Day of St. Anthony in front of the old Ysleta del Sur church.

13 June ca. 1898.

Courtesy: Arizona State Museum University of Arizona. $)^{15}$ 
Cacique Mariano Colmenero and a Texas Ranger at the dedicatory ceremonies of Elephant Butte Dam in 1916. Courtesy: Institute of Texan Cultures.) $)^{16}$

Tigua Indian Alfredo Holquin in WW I army uniform. (Courtesy: David Sinclair.) $)^{17}$
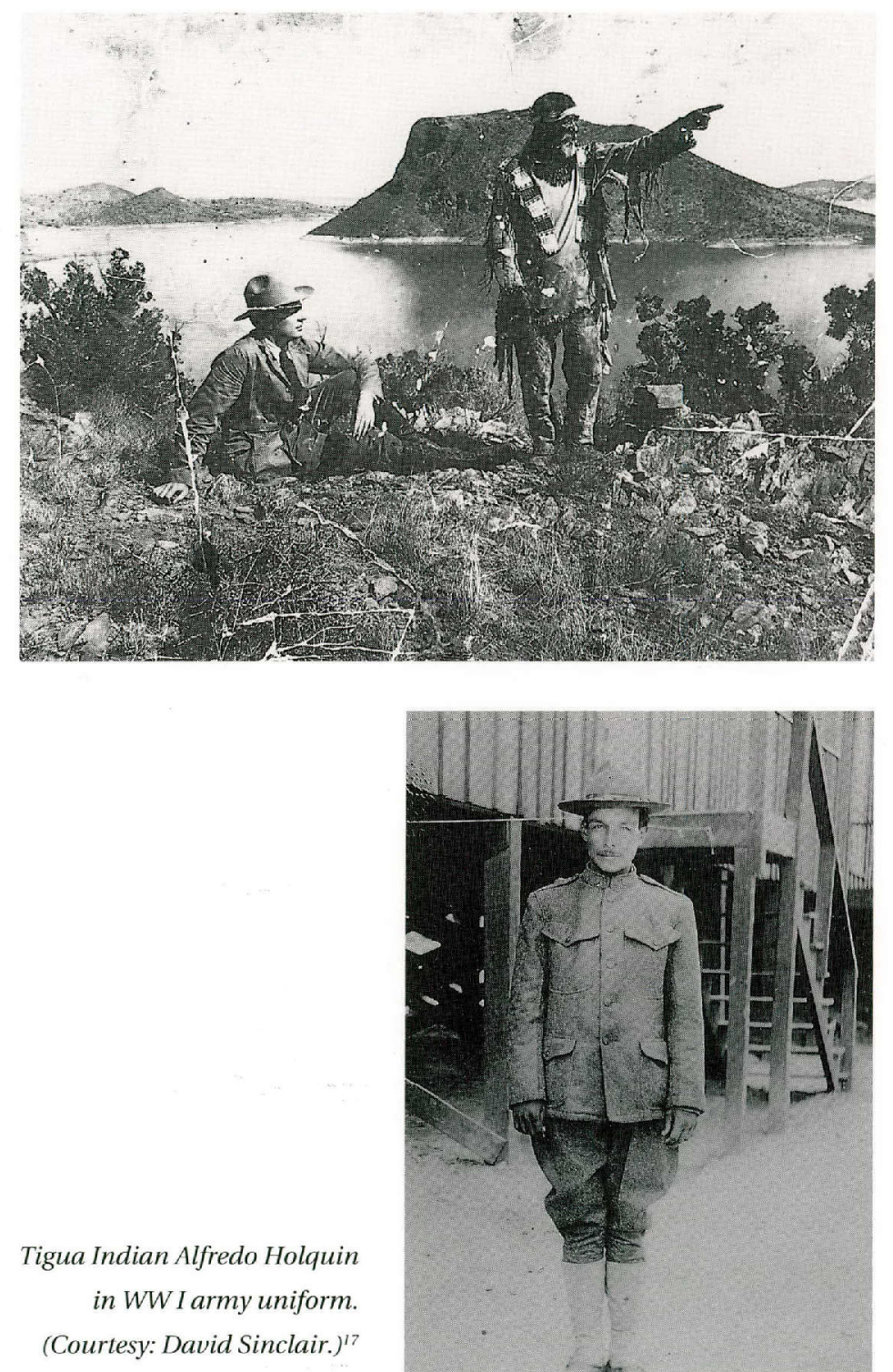

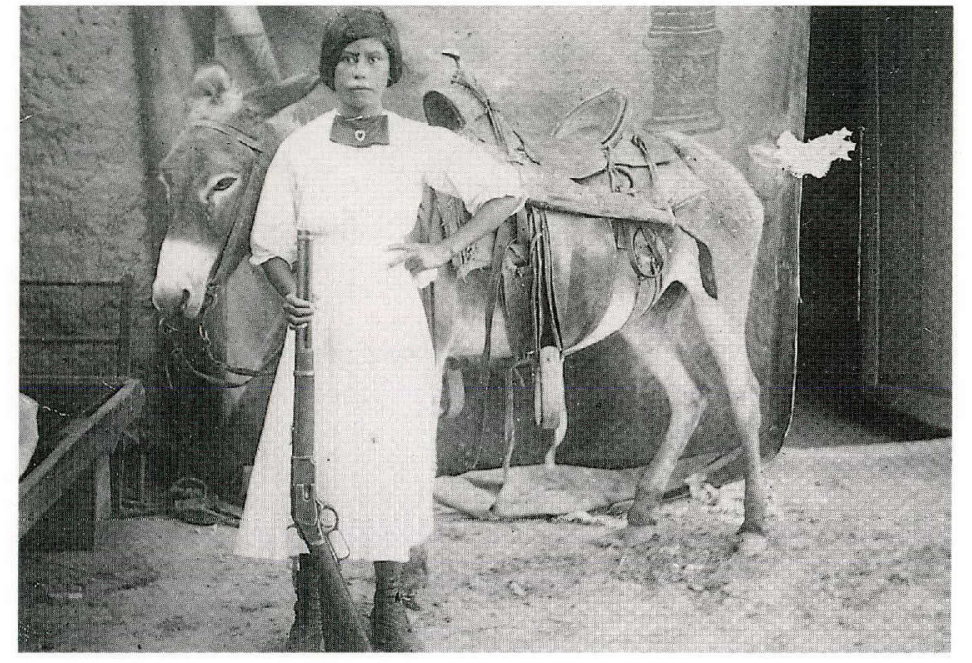

Ramona Paiz standing before the donkey of her uncle,

Chief Mariano Colmenero, with his Winchester rifle.

(Courtesy: Arizona State Museum, University of Arizona. $)^{18}$ 


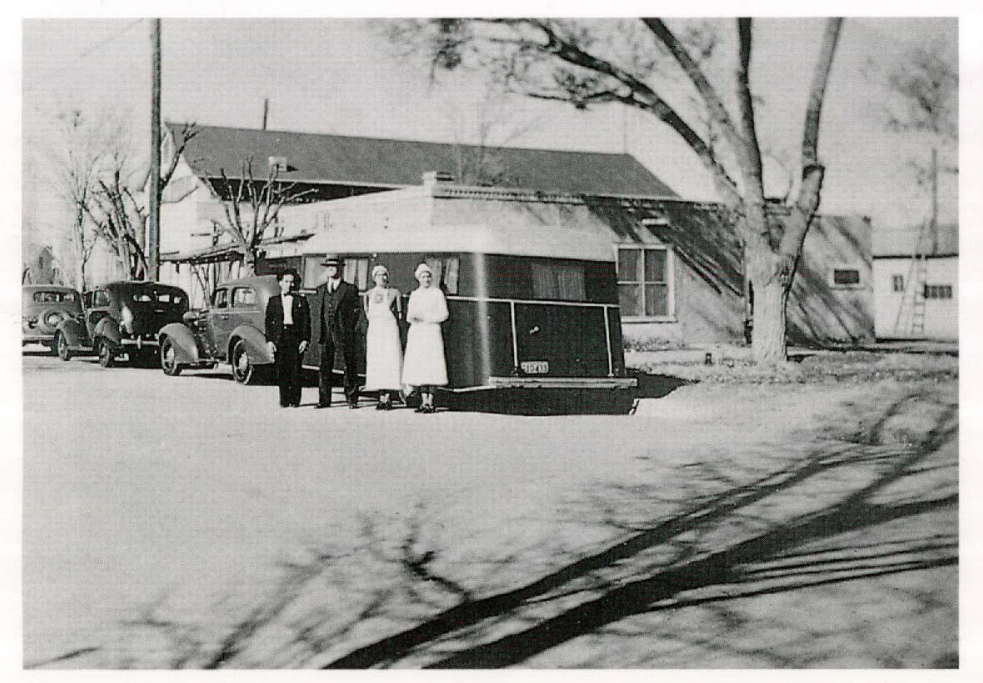

Dr. Gerome D. Love and his mobile maternity clinic.

From the left are Manny Rodela (Dr. Love's driver and a Tigua Indian), Dr. Love, Mrs. Isabel Lopez, and assistant Aurora Rodela. (Courtesy: Manny Rodela) ${ }^{19}$

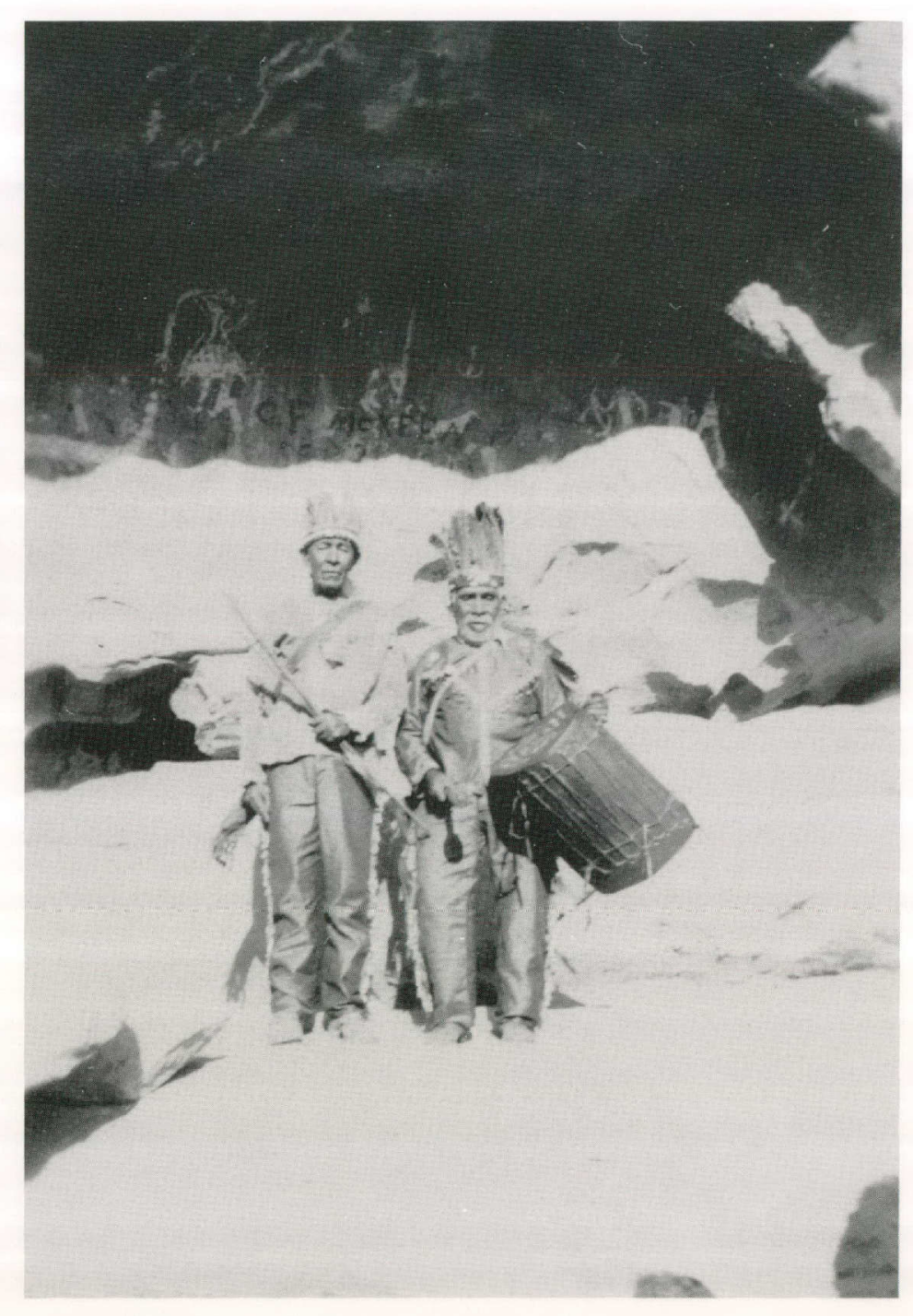

The former Cacique Damacio Colmenero (left) and Sebastión Durán at Hueco Tanks. The drum is called Juanchiro or "one that speaks with great thunder." (Courtesy: Rosemary Hisa.) ${ }^{20}$ 
Bus delivering Tigua Indians to the Third Annual National Folk Festival Program. Texas Centennial Exposition in Dallas, Texas, 14-21 June 1936. (Courtesy: Institute of Texan Cultures. $)^{22}$

Manuel Ortega, cacique, at Dallas exposition prior to 1930. (Courtesy: Arizona State Museum,

University of Arizona. $)^{21}$

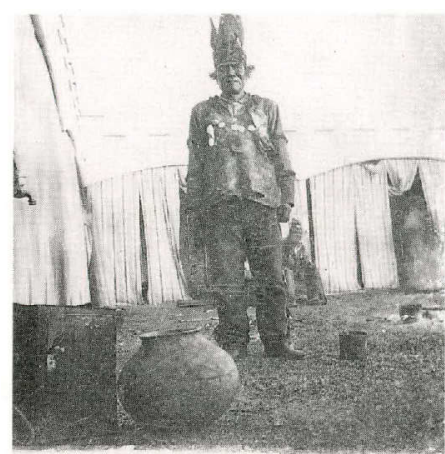

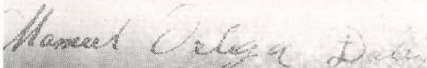

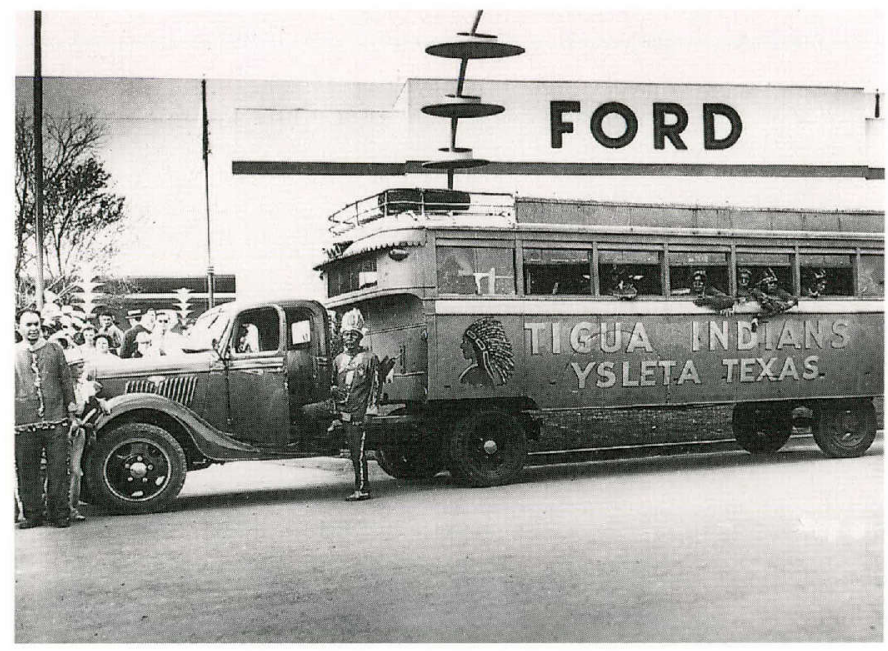

President and Mrs. Franklin D. Roosevelt being invested with the titles of cacique and squaw of the Tigua Indians, by Adelantado Cleofas Calleros and Cacique Damasio Colmenero at the Cotton Bowl in Dallas, 12 June 1936. (Courtesy: Institute of Texan Cultures.) ${ }^{23}$ described their responsibilities. The mission church that Fewkes described burned the night of 14 May 1907. Old accounts cite chemicals used to eliminate bats as the source of the fire. ${ }^{29}$ The church was rebuilt in its present form by 15 May 1908.

Finally, in 1924 something good happened for the Tiguas; they, along with all Indians, were made citizens of the United States by an act of Congress and were given the right to vote.

During the 1936 Texas Centennial, eighty-seven-year-old Damasio Colmenero, the Tigua chief, made President Franklin D. Roosevelt an honorary chief. The act symbolized friendship between two heads of state. ${ }^{30}$

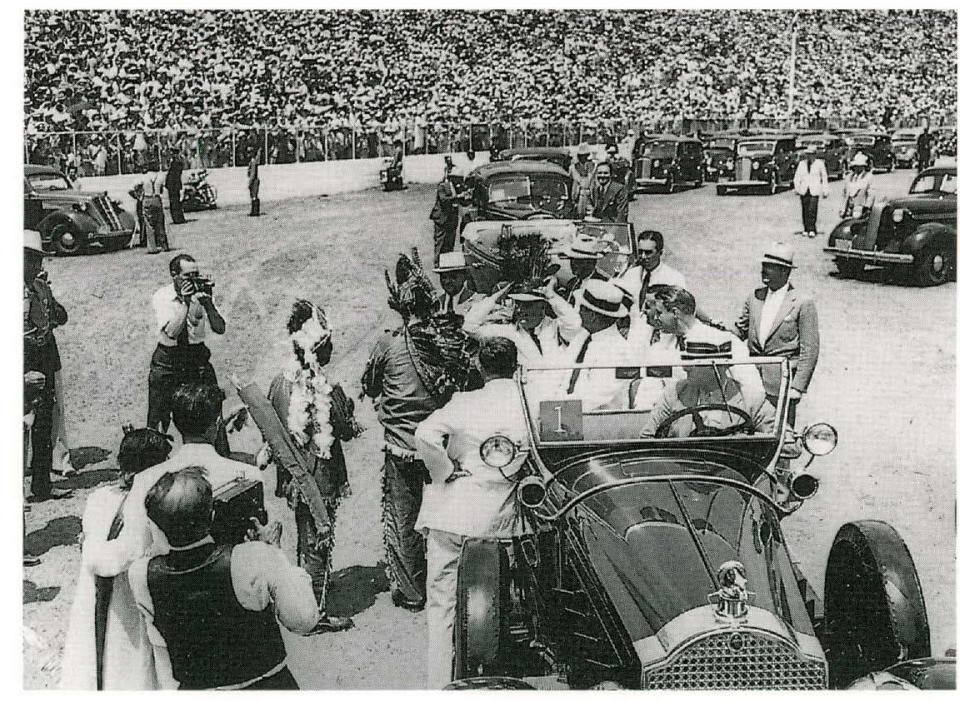




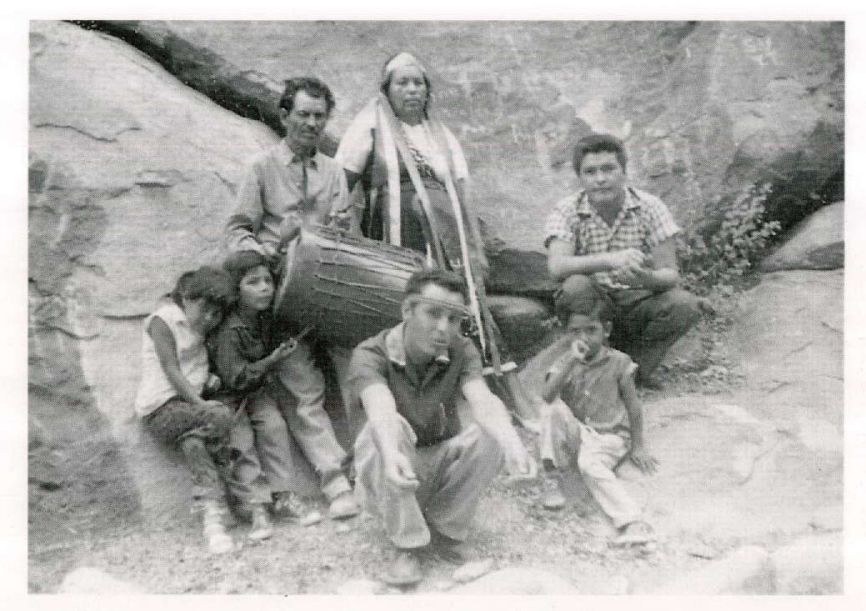

Tigua Indians at Hueco Tanks with pictographs in July 1959.

Ramon Silvas (front) and Joe Sierra (front right).

(Courtesy: Rosemary Silvas. ${ }^{24}$

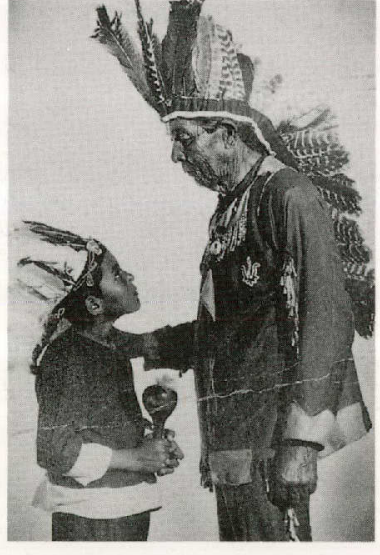

Cacique Damasio Colmenero and his grandson, Santiago Valdez, Ysleta, 16 May 1941. (Courtesy: Miguel Pedraza.) ${ }^{25}$

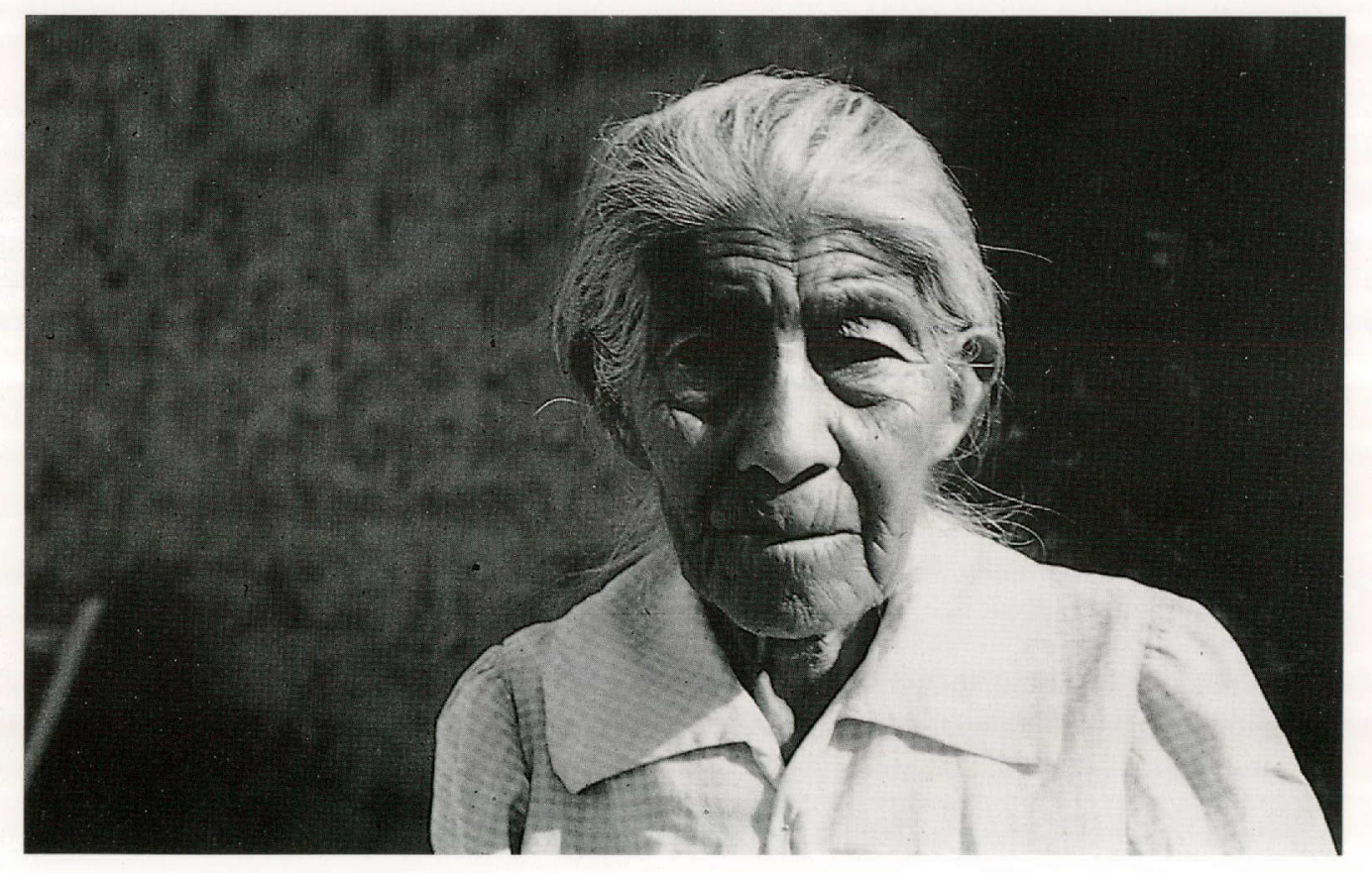

Juanita Padilla, a Tigua Indian

with some Piro ancestry.

Photograph taken in 1966.

(Courtesy: Nicholas Houser. $)^{26}$ 
Trinidad Granillo's house in the Old Pueblo on Palla Street. Fiestas were held in the courtyard, and in 1967 the first meeting was held here in the campaign to establish official recognition for the Tigua Tribe. (Courtesy: Tom Diamond.) ${ }^{27}$

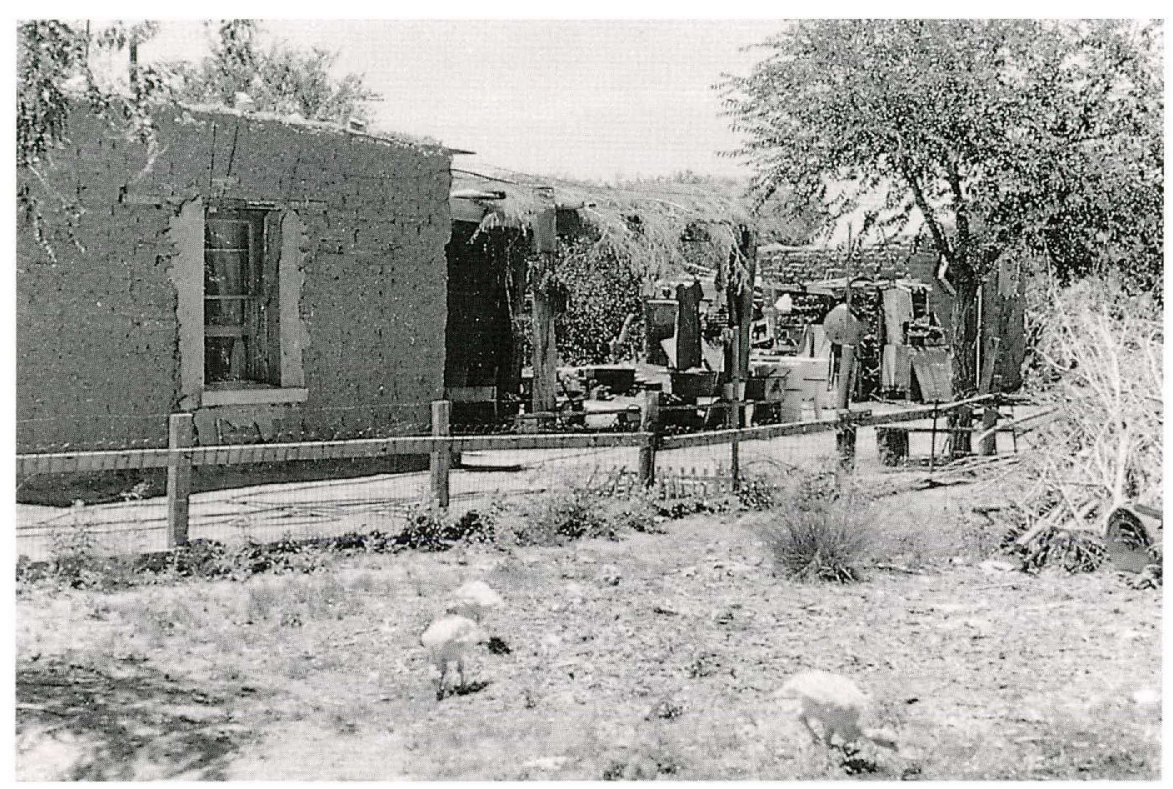

Herminia Silvas and former governor Pablo Silvas on Horizon Mountain near Hueco Tanks ca. 1969. (Courtesy: Herminia Silvas.) ${ }^{28}$

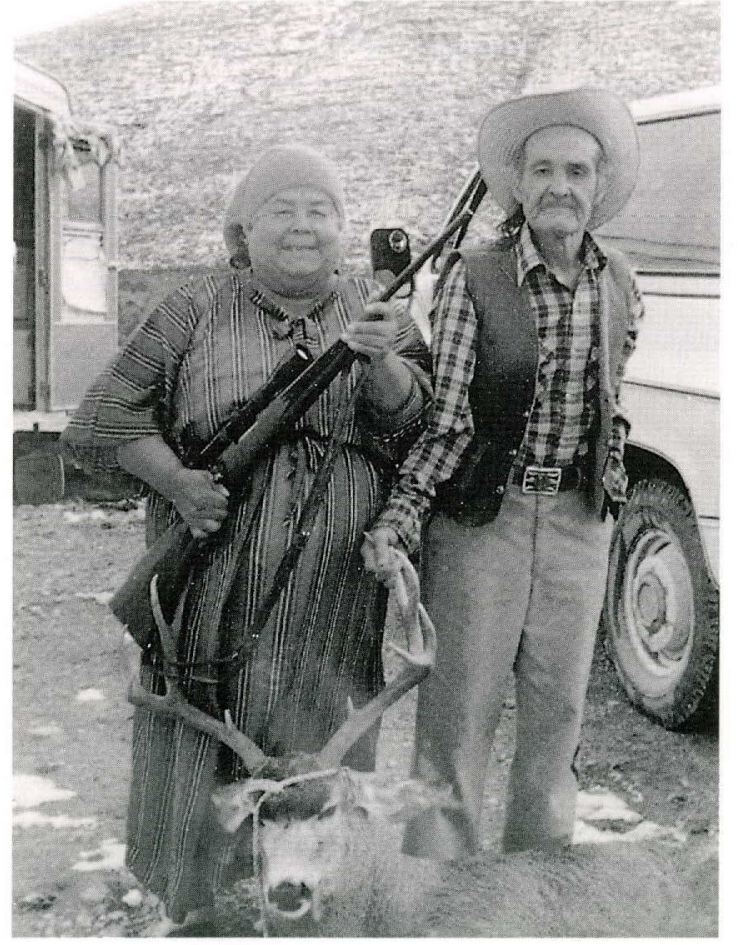


The fortunes of the tribe continued to improve. In 1965, the 59th Texas State Legislature established a Commission for Indian Affairs consisting of three members, appointed by the governor with the advice and consent of the Senate. Following this action, on 23 November 1966, with help from attorney Tom Diamond and anthropologist Nicholas Houser, the Texas State Historical Survey Committee passed a resolution recognizing the Tiguas as a tribe, and the Texas Legislature passed two bills in 1967 placing the Tigua Indian Tribe under state care. The first superintendent for the Tigua Tribe appointed by the Texas Commission for Indian Affairs was Alton L. Griffin.
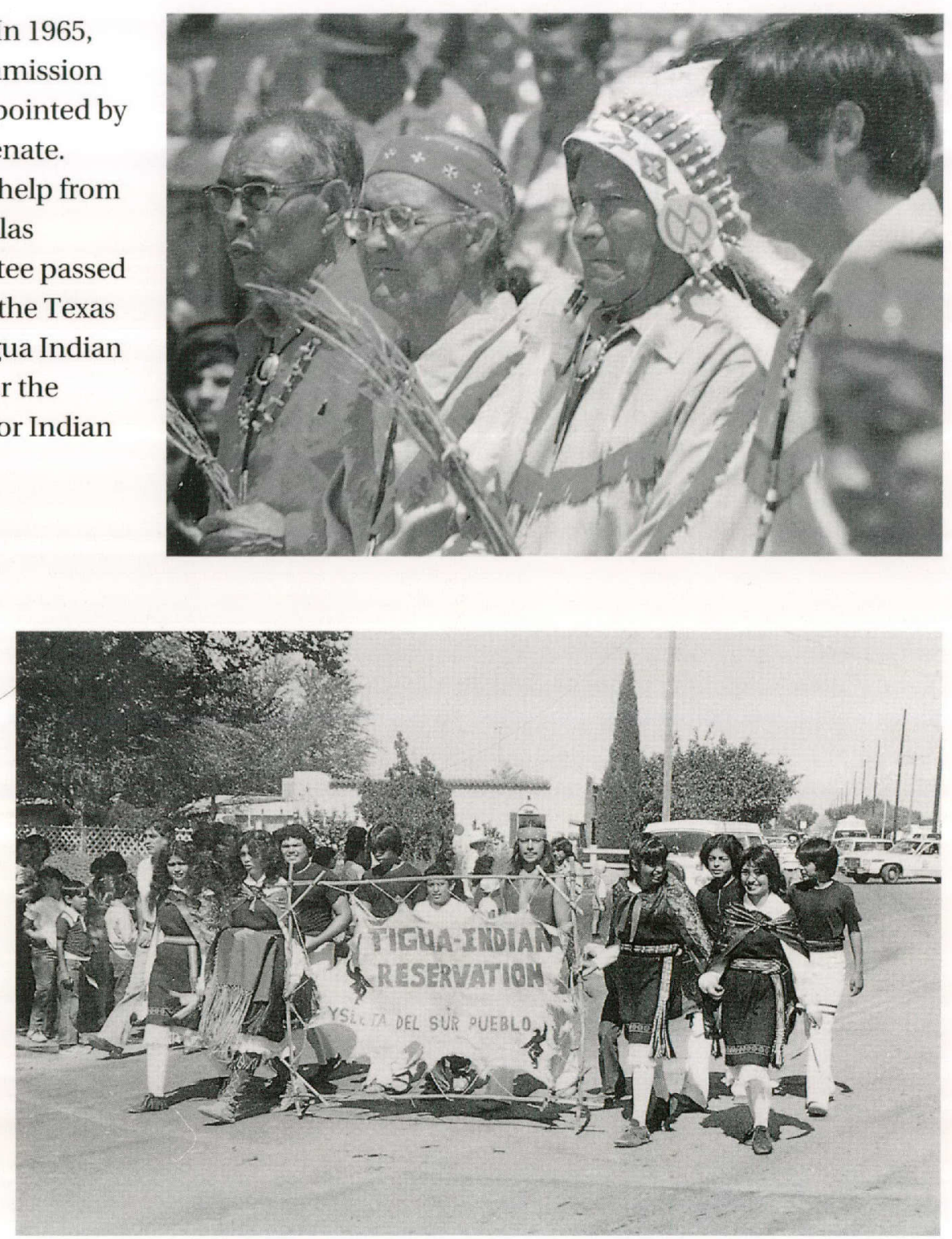

Bicentennial celebration in Dallas, 3July 1968. From the left are Governor Miguel Pedraza, Sr., Lieutenant Governor Pablo Silvas, Sr., Cacique José Granillo, Alguacil Joe Sierra, and Antonia Zavala. (Courtesy: Leonard G. Garcia.) ${ }^{29}$

Youth group from the Tigua Cultural Center participating in the El Paso Sun Carnival Parade, ca. 1980. (Courtesy: Tigua Pueblo Administration. ${ }^{30}$ 
George Candelaria, Estella Gomez, and others baking bread at the Tigua Visitors' Center, ca. 1983.

(Courtesy: Ysleta Pueblo Administration. $)^{31}$

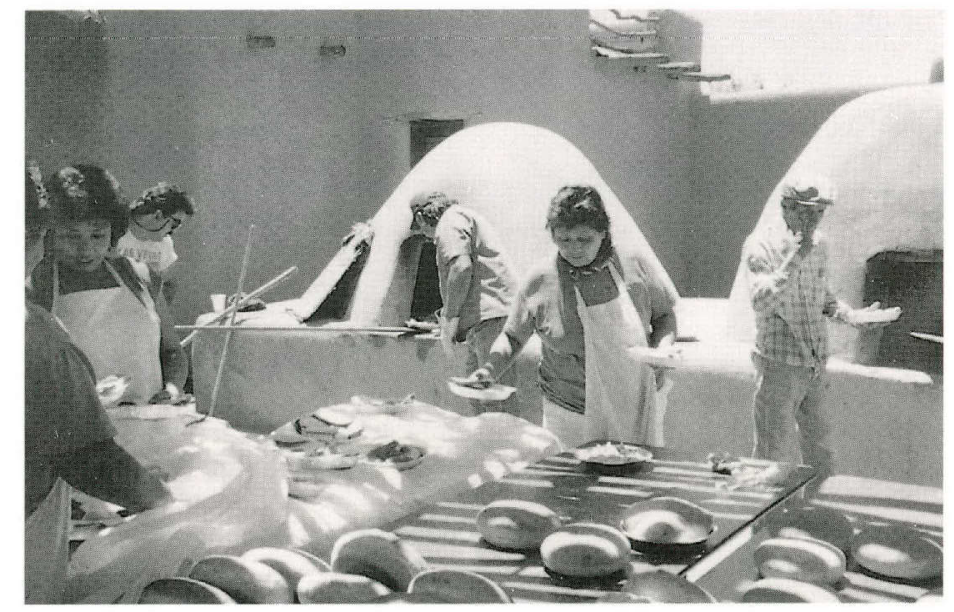

But it remained for President Lyndon Johnson to make official what the Tiguas had known for hundreds of years. On 12 April 1968, Public Law 90-287 was signed by President Johnson, stating that "the Indians now living in El Paso County, Texas, who are descendants of the Tiwa Indians of the Ysleta (Isleta) del Sur Pueblo, settling in Texas at Ysleta in 1682, shall from and after the ratification of this act be known and designated as the Tiwa Indians of Ysleta, Texas...." The bill, sponsored by Congressman Richard C. White, also transferred the Tiguas to the jurisdiction of the State of Texas.

Tribal members preparing to roast a pig for the community meal given by the tribal governor in 1990. (Courtesy: Ray Apodaca. $)^{32}$

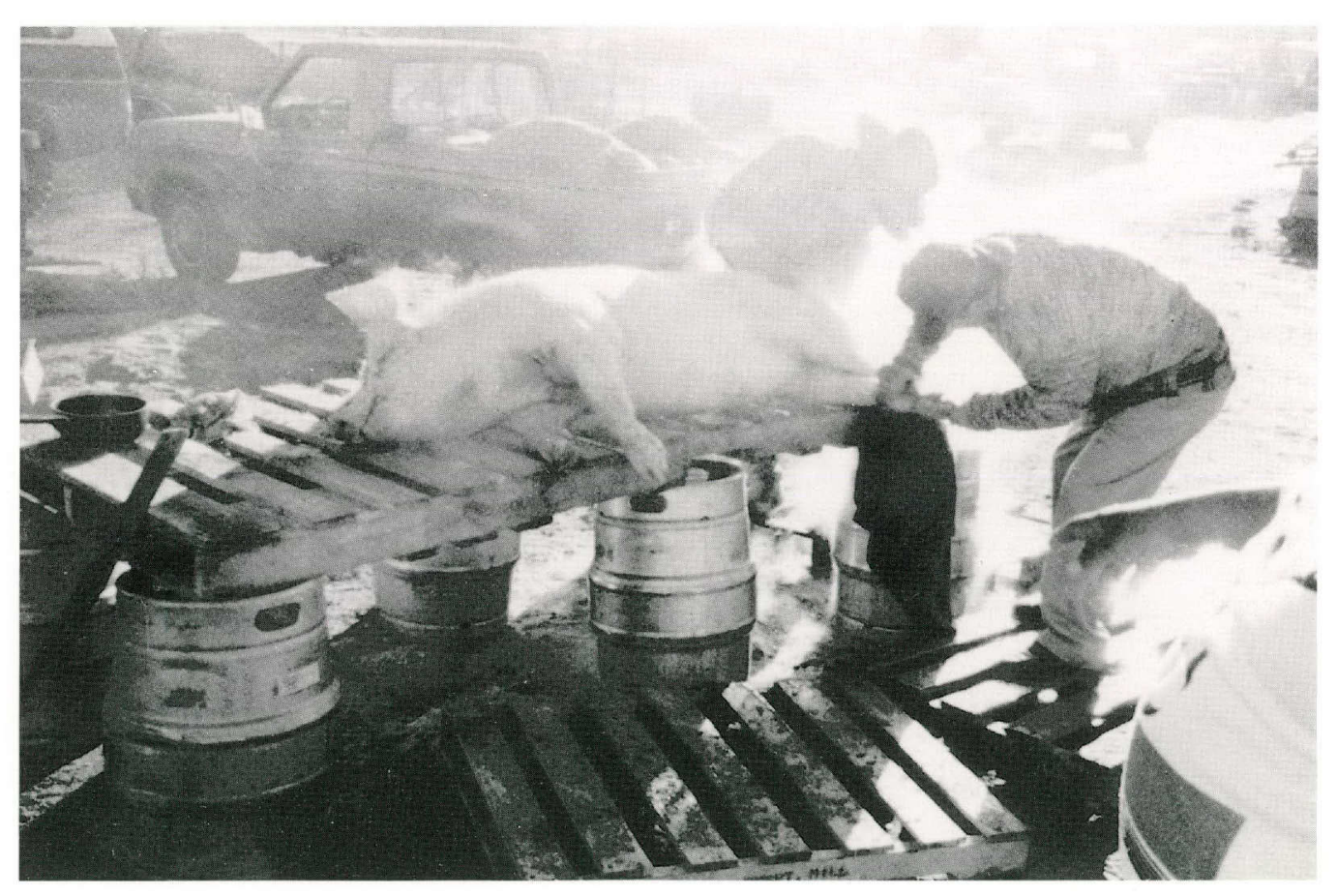


The Texas Legislature appropriated funds for a tribal administrator, a small parcel of land for a restaurant, a visitor center and administration building, and other services, but still the Tiguas had no extensive land holdings comparable to those of the New Mexico Pueblo Indians. With the assistance of attorney Tom Diamond of El Paso they initiated legal action to regain the Ysleta land grant, consisting of approximately thirty-six square miles in the valley below El Paso. The suit was still pending in 1992.

In 1989 the Texas Legislature terminated the Texas Commission for Indian Affairs, and Ray Apodaca, the executive director and a Tigua Tribe member, returned to $\mathrm{El}$ Paso. After state termination, the United States Government agreed to extend trust status to the tribe, and presently tribal matters are administered by the Bureau of Indian Affairs in Washington, D.C.

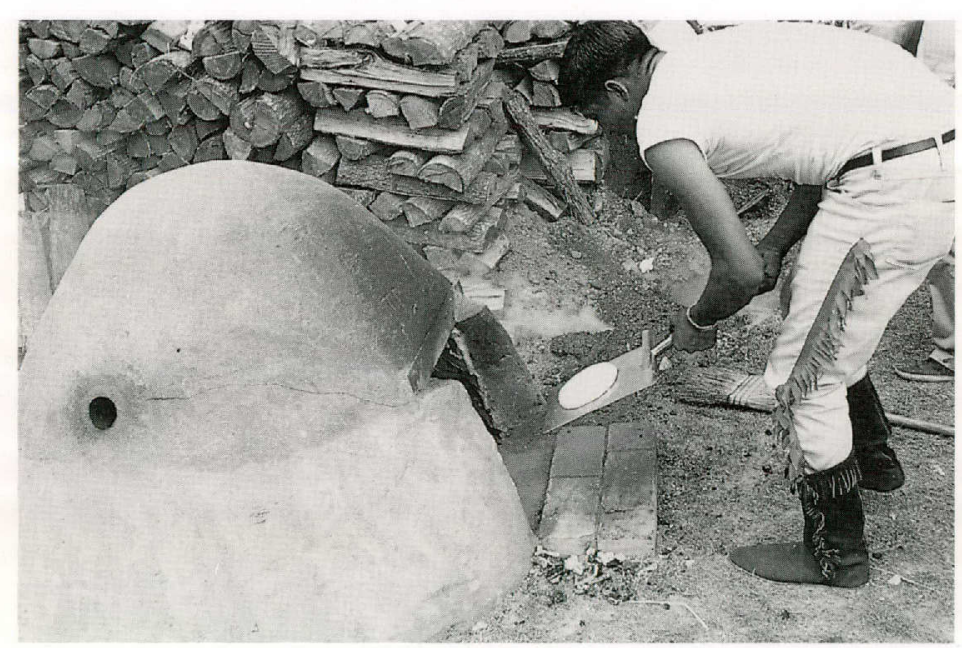

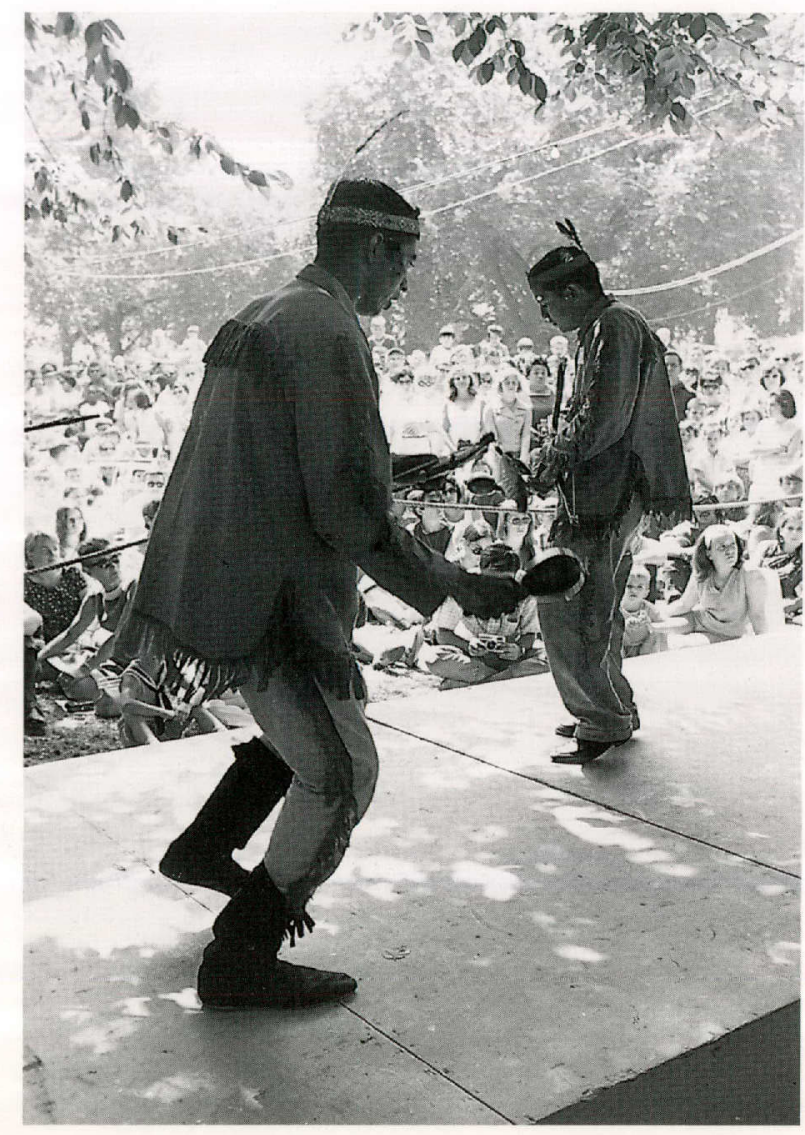

Donstration of Tigua dances at the 1968 Festival of American Folklife, Washington, D.C.

(Courtesy: Smithsonian Institution.) (33 $^{33}$

Demonstration of bread making at the

1968 Festival of American Folklife, Washington, D.C.

(Courtesy: Smithsonian Institution. (34 $^{34}$ 


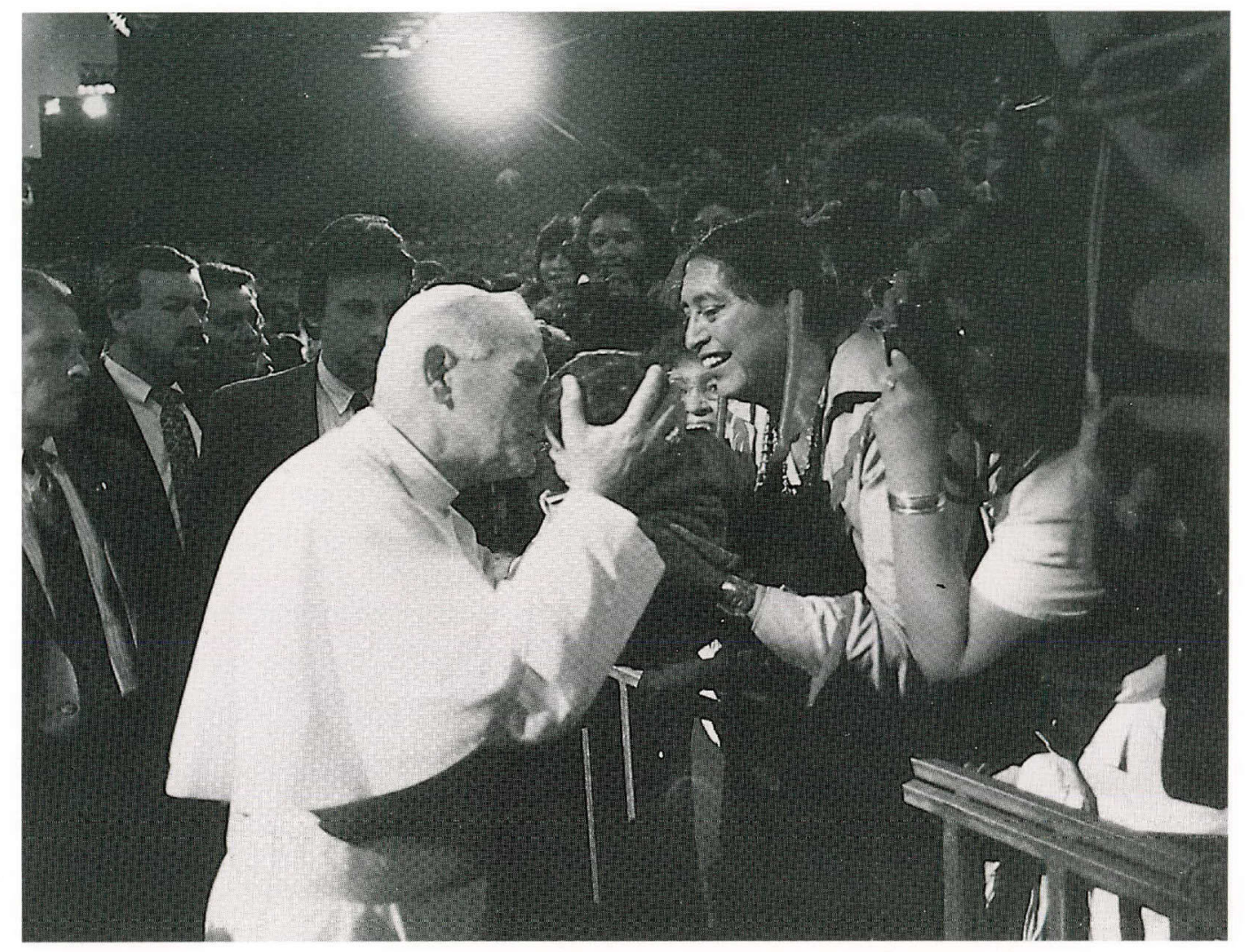

Joe Sierra with Indian boy meeting Pope John Paul II in

Phoenix, Arizona, in 1988.

This meeting involved representative tribal members

from throughout the United States.

(Courtesy: Joe Sierra.) ${ }^{35}$
Since their first encounter with the Spanish, the Tiguas have surmounted many obstacles to survive as a tribe. Other Pueblo groups - the Mansos and Piros were absorbed into the local population and disappeared as distinct cultures. The Sumas are no longer identifiable. But the Tiguas have remained; they have held fast to their cultural identity even though they have lost most of their language and intermarried with other Indians and Hispanics. Now intermarriage poses a formidable problem. Under the federal government's terms of trusteeship, persons must have a "blood quantum" of at least one-eighth Tigua ancestry to be carried on the tribal rolls. Because the tribe is so small, it is virtually impossible to marry within the tribe without marrying a cousin. Most of the young people reject this option and marry outside the tribe, ensuring that sooner or later the general blood quantum will be diluted below the statutory limit.

Will the rules change? Will the Tiguas renegotiate a lower blood quantum with the government? Will they continue their traditional rituals and distinct cultural practices regardless of federal designation? Somehow, they will survive. After all, three hundred years of intercultural relations have taught the Tiguas resiliency. They are not apt to forget what they have struggled to preserve. ${ }^{31}$

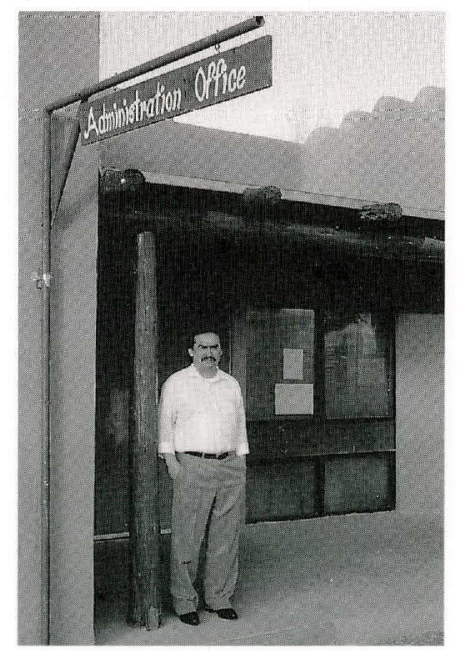

Governor Julian Granillo in front of Tigua administration office. He was elected in 1993 (Source: Bill Wright Photography Collection $)^{36}$ 



\section{ThePlace}

YSLETA DEL SUR PUEBLO

ELPASO, TEXAS 
The Ysleta del Sur Pueblo, home of the Texas Tiguas, is located in Ysleta, now a part of El Paso, Texas. The Tigua tribal members live throughout the area and the nation with some six hundred living in the HUD development on tribal lands near the Mission of Our Lady of Mount Carmel, the mission established for Indians by the Spanish after their journey to the area in 1680 .

The original habitations were of mud and the branches of trees....similar to jacal structures in use today. As the development of the area continued, the Indians became concentrated in an area that was known as the Barrio de los Indios to the Hispanic population surrounding them. Later, after the construction of the HUD housing, it was called the Old Pueblo.

In addition to the homes and the mission, the Tigua Tribe operates two modern restaurants and a visitor interpretation center with historical displays, craft sales, and demonstra-

tions. There is a regular schedule of social dances performed by tribal members during the summer tourist season.

Gran Quivira, according to oral tradition, was the ancestral home of the Tiguas of Ysleta del Sur. The pueblo was abandoned around 1675 due to encroachment by hostile Plains Indians. The Tiwa-speaking inhabitants of Gran Quivira, along with those of the other Salinas Valley Pueblos, migrated to Isleta Pueblo, near present-day Albuquerque, and to other locations along the Rio Grande and west of the mountains, some as far south as El Paso del Norte.
Because the Spanish made intensive efforts to Christianize these Gran Quivira Indians, some postulate that these peoples were more comfortable with the Spanish and less likely to revolt against the occupying forces than the older residents of Isleta, New Mexico, and constituted the majority of the group that accompanied the Spanish refugees to El Paso del Norte in 1680. Possibly they were also the group that remained in Ysleta del Sur after the reconquest of the pueblos by De Vargas. In 1718 Isleta, New Mexico, was reoccupied by the Tiguas who had dispersed during the revolt and by some who returned from Ysleta del Sur.

This is home to me, this is really home. Just by looking at the area, you know, I hear wind. I feel at peace, I feel like I am at one with nature, and nature is with me, side by side. I could stand there and squat, and mess with the pebbles, touch the rocks, walk around, look to the horizon, and feel comfortable. I feel at peace. I feel like there are spirits around, I feel like I could communicate with them, I feel like I am understood. It's almost like a security blanket. It is a good feeling.

To me, any place that I go that is a ruin, it is part of me and I am part of it, whether it is in Arizona, or New Mexico, whether it is out in South Dakota, there is a relationship. Being native, being able to relate to that sight... the ruin... the peace behind it, the understanding of the culture, the struggles. All of this old history says that this was our home, to me, Mother Earth, Mother Earth is home. This is all home. 


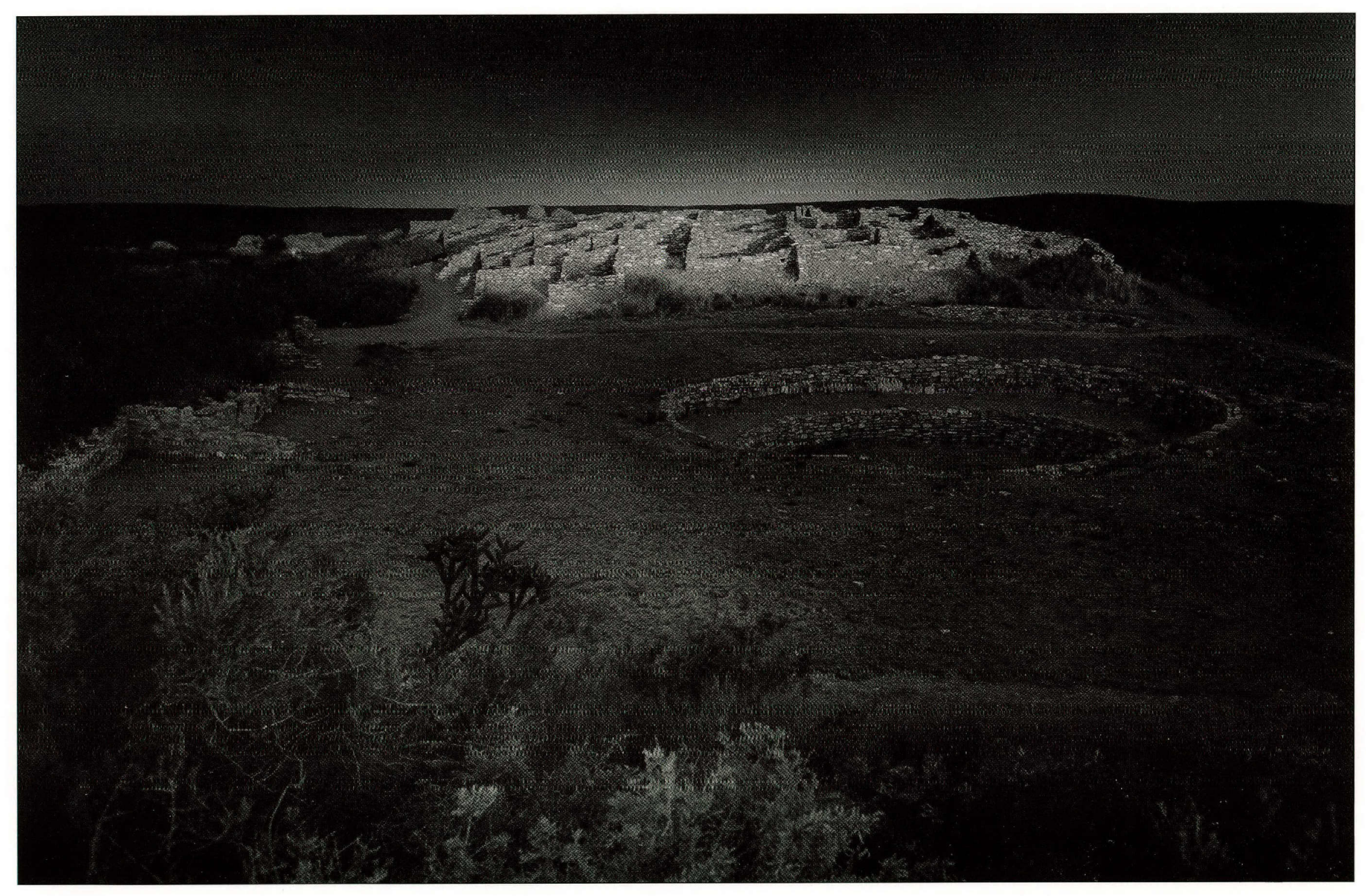


All of the Tigua do not live in the new pueblo because of a shortage of tribal housing. The nearby Old Pueblo, or Barrio de Los Indios, as it is called, is still the location of many tribal members' homes as well as the Tuhla, the sacred meeting house of the tribal council.

The guys here contribute to their own household, most of the men are like this. If something goes wrong, they get out there, they are real handymen. Most of the old homes that they live in, they built themselves. They are the ones, I would be willing to call them the backbone of the tribe, the men. Not taking away anything from the women, because they do have their own say so here and there. 


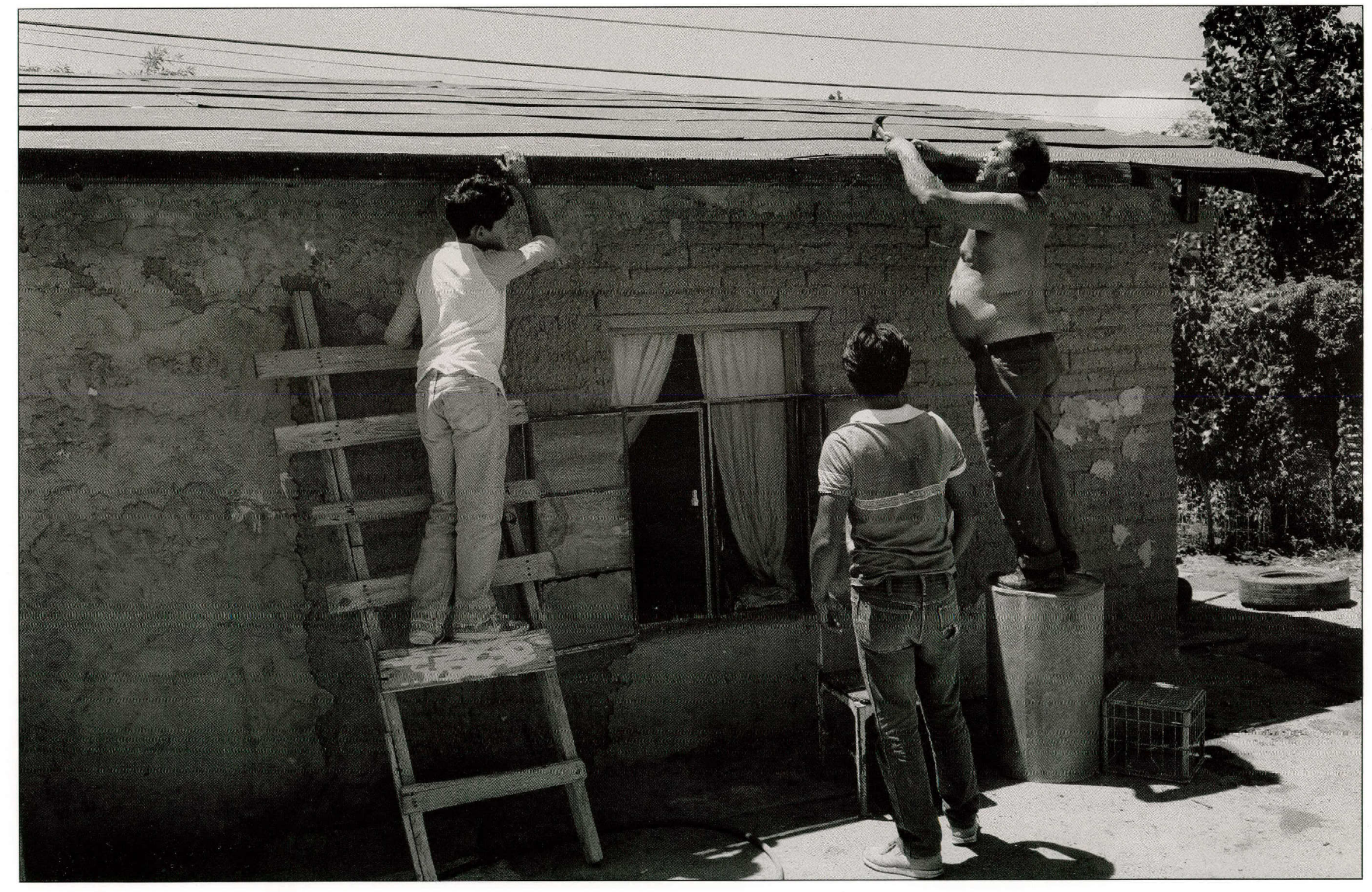


The present housing community has 113 homes, but that is not enough. My waiting list consists of over thirty families. Now, the problem is to find the land to build on.

Outside the HUD housing community, there are a lot of tribal members that are renting, or they have their own homes. The ones that own homes right now, and living in substandard condition, I am referring them to the HIP program, which is the Housing Improvement Program under the BIA. The way this program works is if they qualify, if they have all the qualifica tions that they need to meet for the program, then the HIP will either renovate their homes or even build them a new home.

Rosemary Hisa 


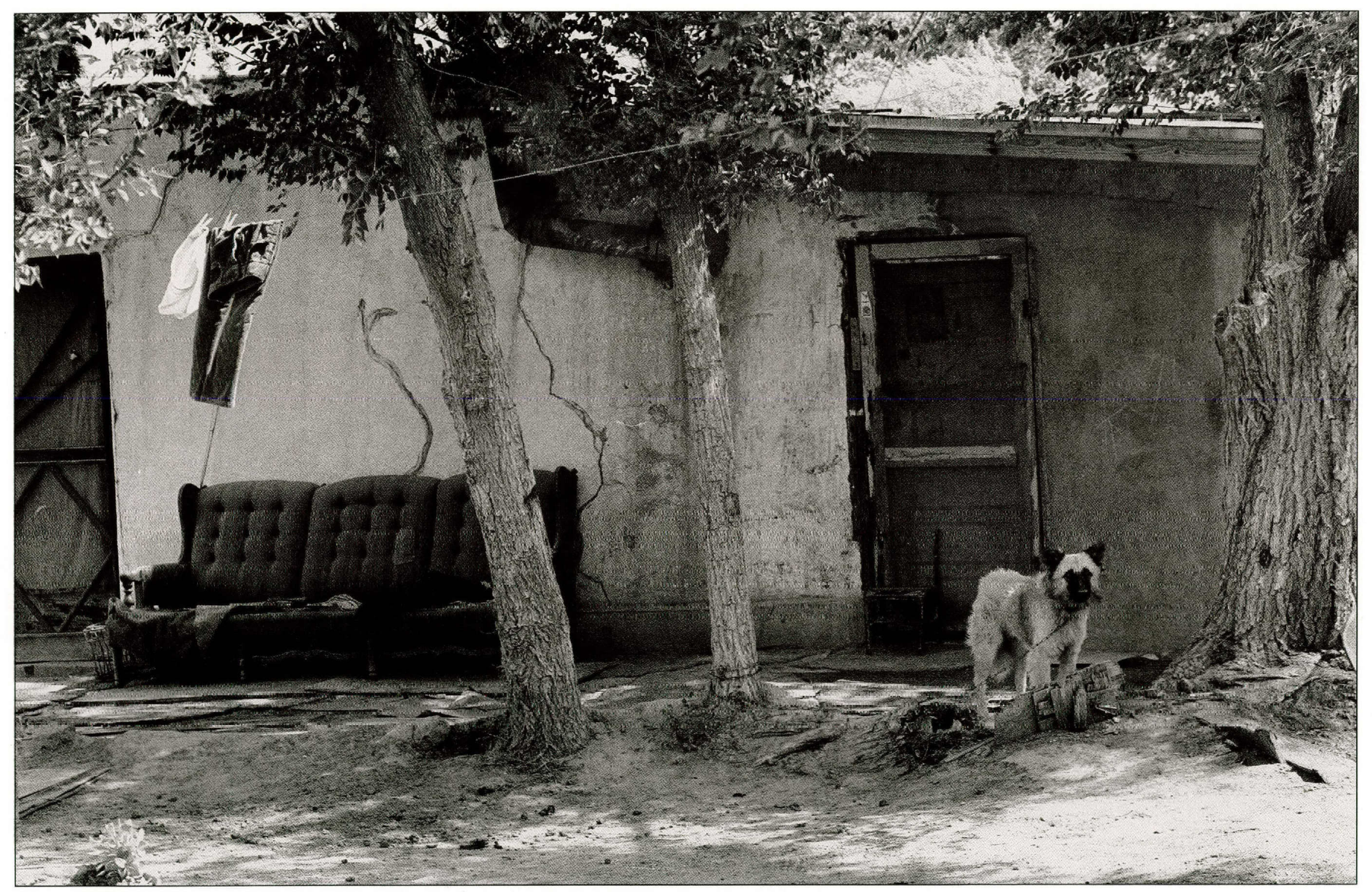


THE JOHNNY AND ROSEMARY

HISA RESIDENCE 


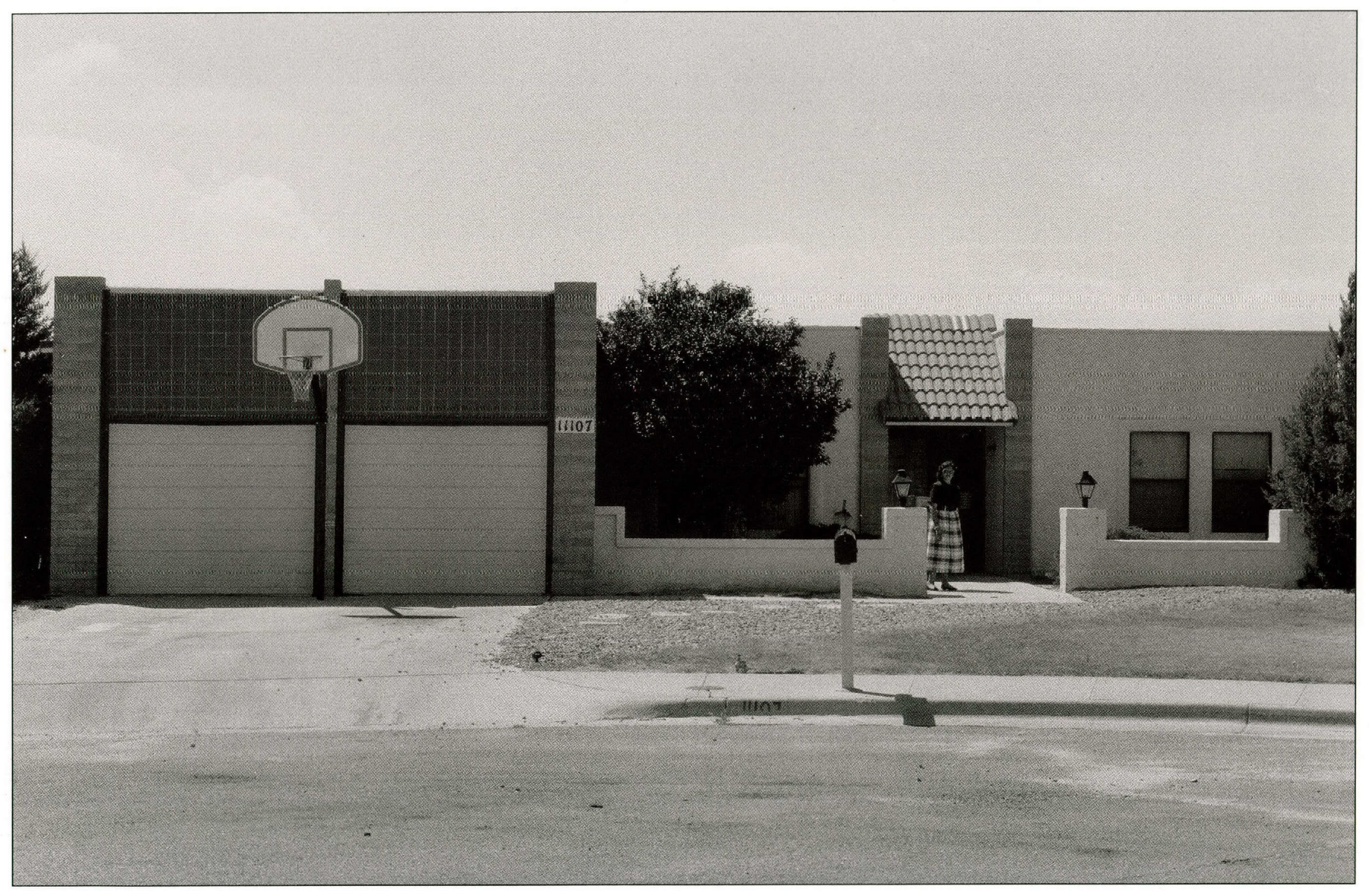


TIGUA VISITOR CENTER

Replica of kiva (above ground). 


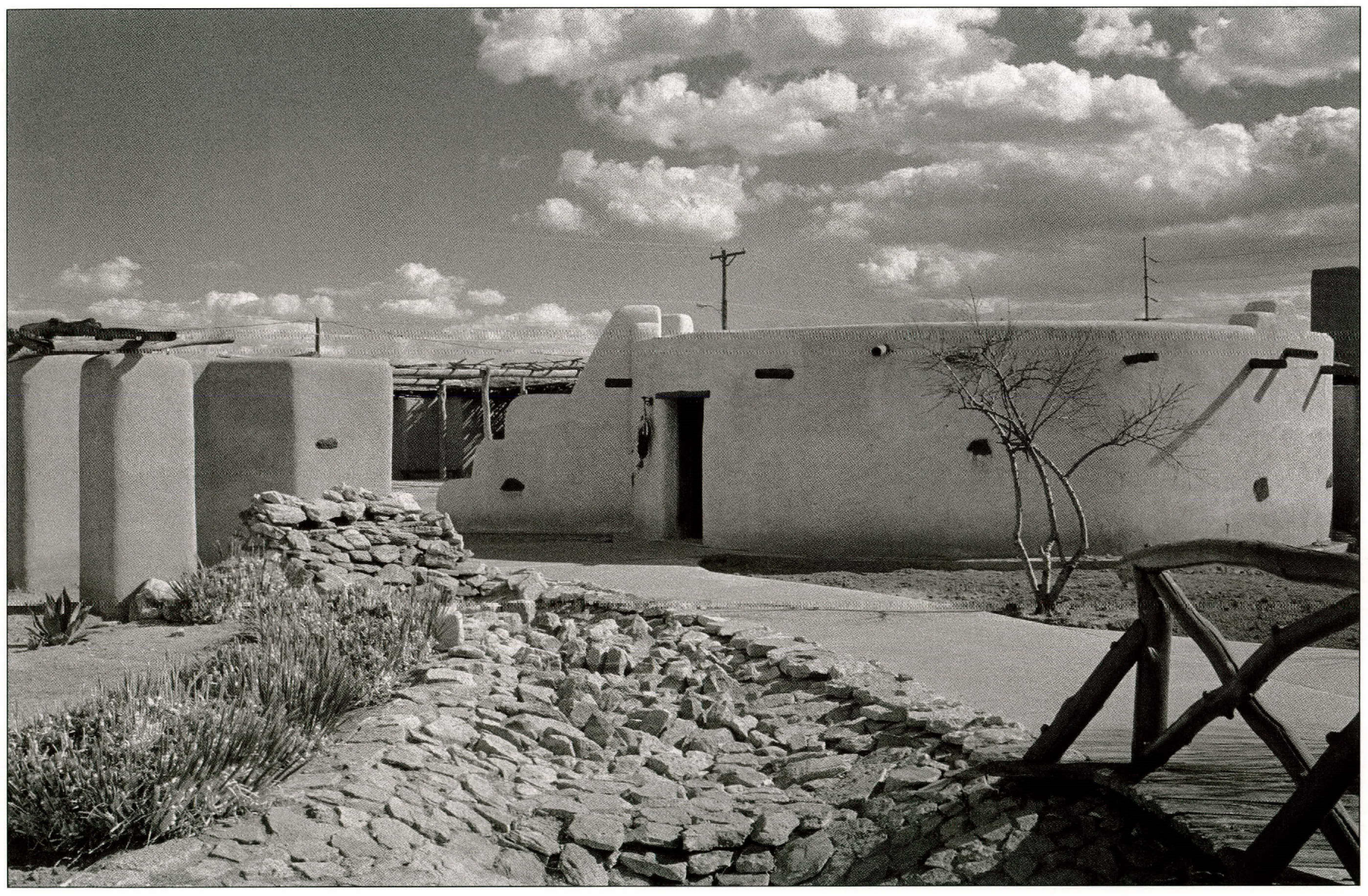


NELLIE LOPEZ DEMONSTRATING BREAD MAKING AT THE TIGUA VISITOR CENTER 


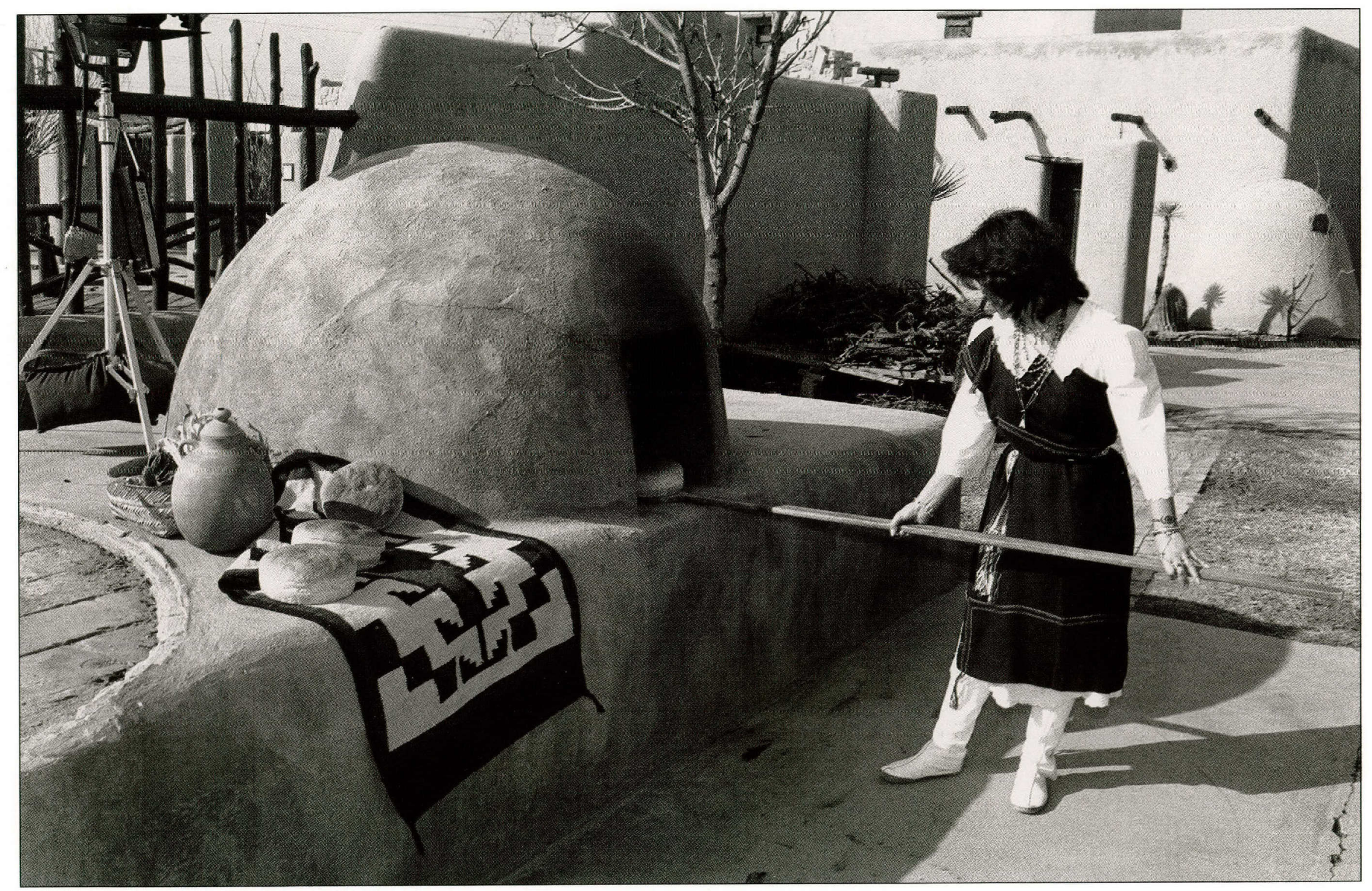





\section{The People}

PUEBLO INDIANS OFTEXAS 
The Ysletans, as they could be called...Tigua is the language... are the descendants of the Indians who accompanied the Spanish from Isleta, New Mexico, as they retreated to the El Paso area during the Pueblo Revolt of 1680 . Since that time, they have lived quietly, working at various jobs and continuing their tribal organization and family relationships.

TIGUA VISITOR CENTER COURTYARD

Replica of Pueblo Courtyard, built in 1972

For many years the Indians were regarded as Mexican by their Anglo neighbors, an impression cultivated by the Indians themselves because they were less discriminated against as Mexicans. They gained federal recognition as a tribe on 12 April 1968, when President Lyndon Johnson signed Public Law 90-287 which officially recognized the Tiguas as a legitimate tribe and transferred their administration to the State of Texas. Now under the trusteeship of the Bureau of Indian Affairs after many years of management by the Texas Commission for Indian Affairs, the tribe is rediscovering some of it's lost language and customs and attempting to preserve this heritage in the midst of an overwhelming western culture. 


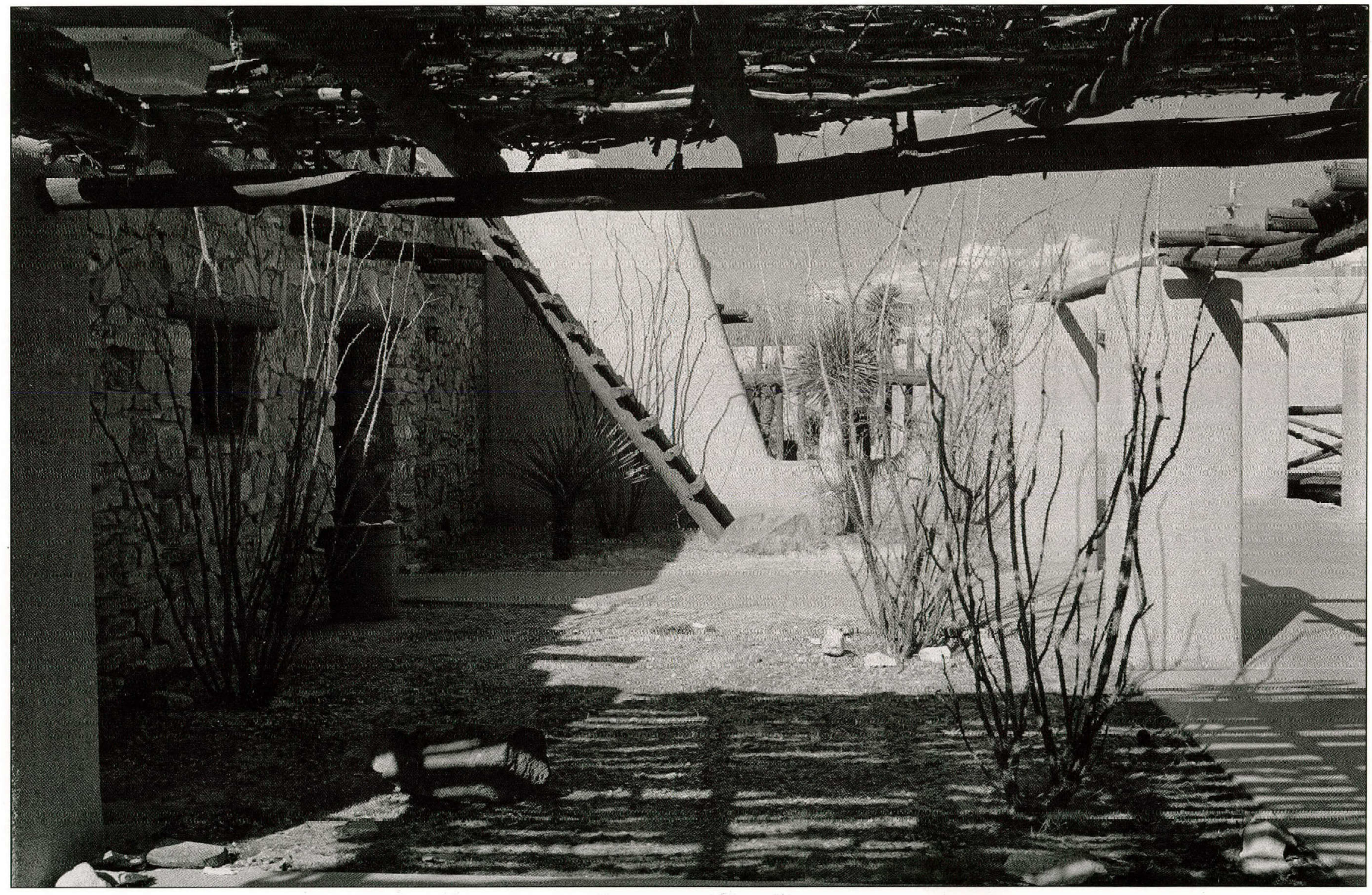


The Tigua Tribe is gradually providing homes for tribal members through a federal program. When Antonio Silvas, his wife, daughter-in-law, and grandchildren moved into their new home, he spoke about their feelings: "We can't believe this wonderful thing has happened to us. Before, we had nothing to leave our children. Now it is different."

Victoria Silvas said, "Every day I would pray to God that we would have a house. Our prayers are answered."

I see our Tigua families as having gone through a heck of a lot. Unlike my family, because we moved into the community about thirteen years ago, these families have been around this area all of this time. They have seen the pueblo develop and grow in administration and government, in economic development projects, such as our restaurants, but some of these families still struggle. When I first moved in, I noticed that a Tigua family was very much a family. There was bickering and arguments among various families, which I am pretty sure its the same throughout all Indian country, but the Tigua family is ver unique. For one, they have the traditional ways, plus at the same time, you have to fall into a certain "process" to be able to survive the city.
Oh, you should see the way the people's faces light up when they are awarded a home, their children are so happy. It is just a gratifying look. Even now, with the people that live here in the housing community, you can see their pride just by walking around the area, how well kept the houses are, knowing that they will be owners of those homes. I have had five people pay off their homes already.

The land is Indian Trust Land. Therefore, the land will never be owned by the individuals, it belongs to the tribe in general. But the home will be the individual's. 


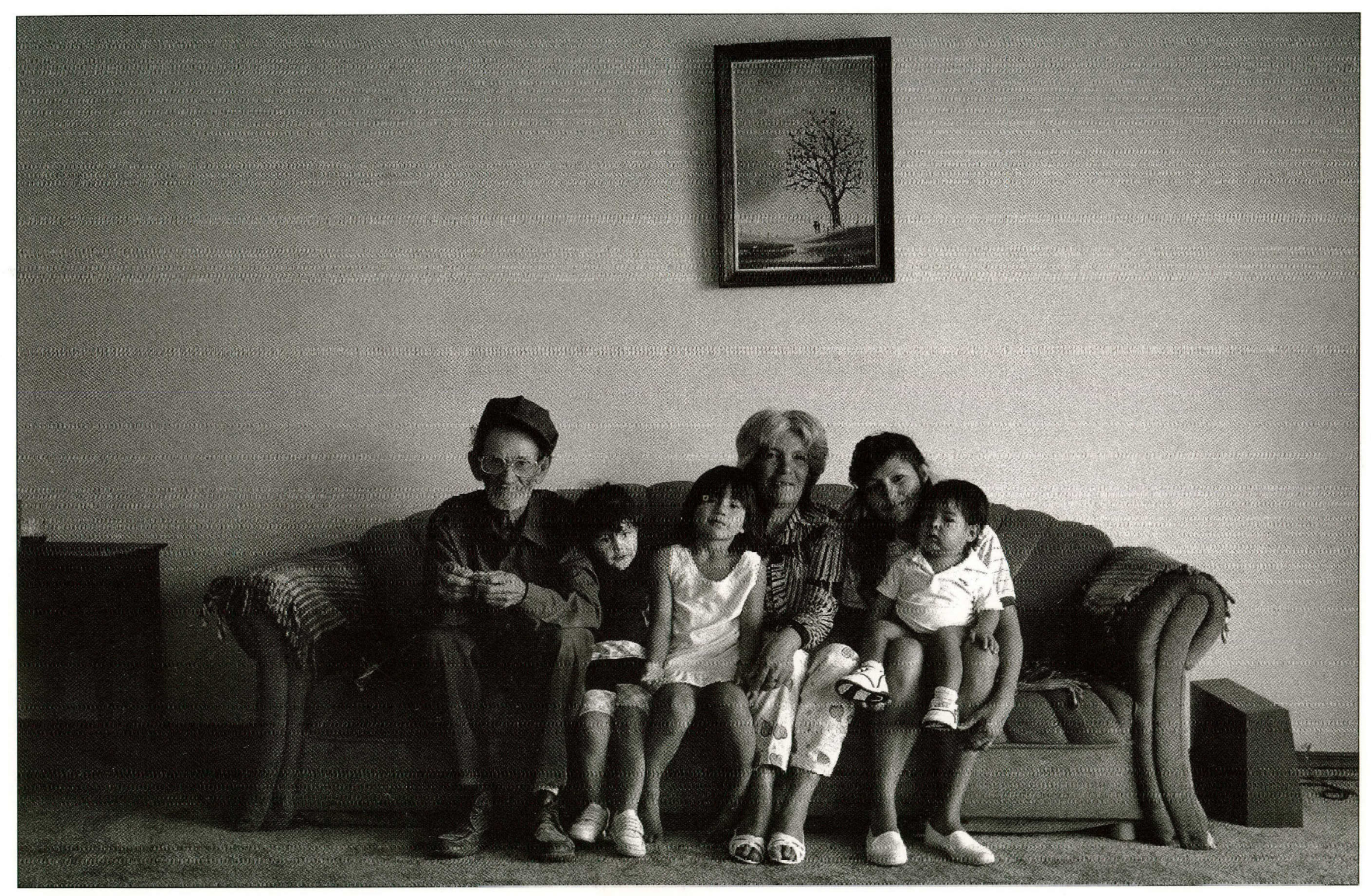


LISA SOTO IN HER BEDROOM 


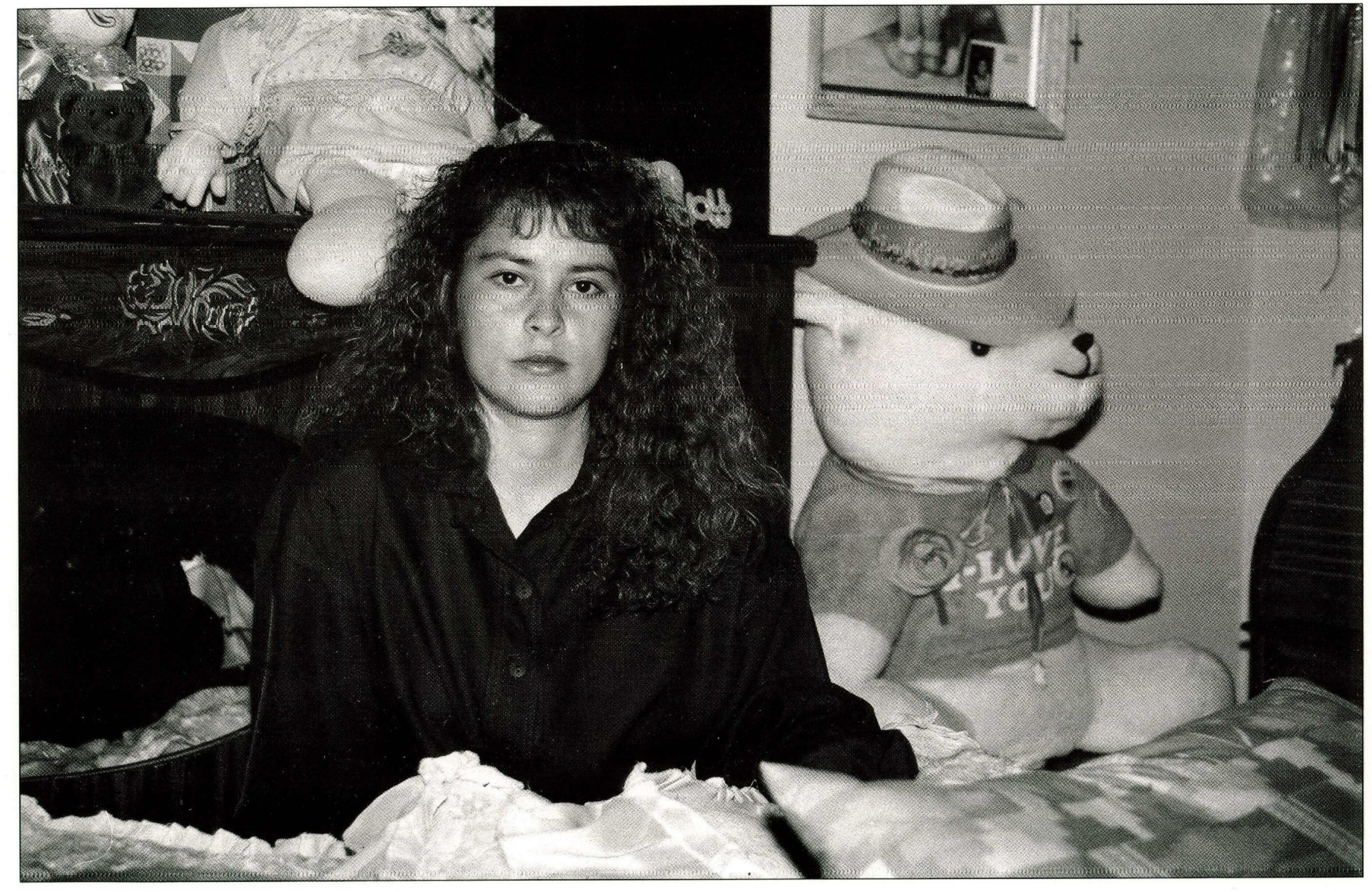


This is the old graveyard where the Indians were buried outside the fence of the Catholic cemetery. This is no longer the practice, but a few of the old graves remain. Leo has the discharge papers of his great-grandfather, citing him for years of faithful and effective service to the United States government.

Leo is a very wise man, he knows a lot. Here is a man who has to separate his Protestant Christian faith from the Indian belief. He can't mix them like the Catholics do, he has to go either or. It is almost like taking off one hat and putting on another. You know your boundaries, you know when to wear this hat and when not to, that is the way Leo is with the culture. I sat with him many times to talk about the songs, his ways, the old traditional ways. He is a very knowledgeable man. He knows a lot of things. I respect him. He is very focused.
LEO GARCIA BEFORE THE GRAVE OF HIS GREAT-GRANDFATHER WHO WAS A SCOUT FOR THE U. S. CAVALRY

Danny Archuleta 


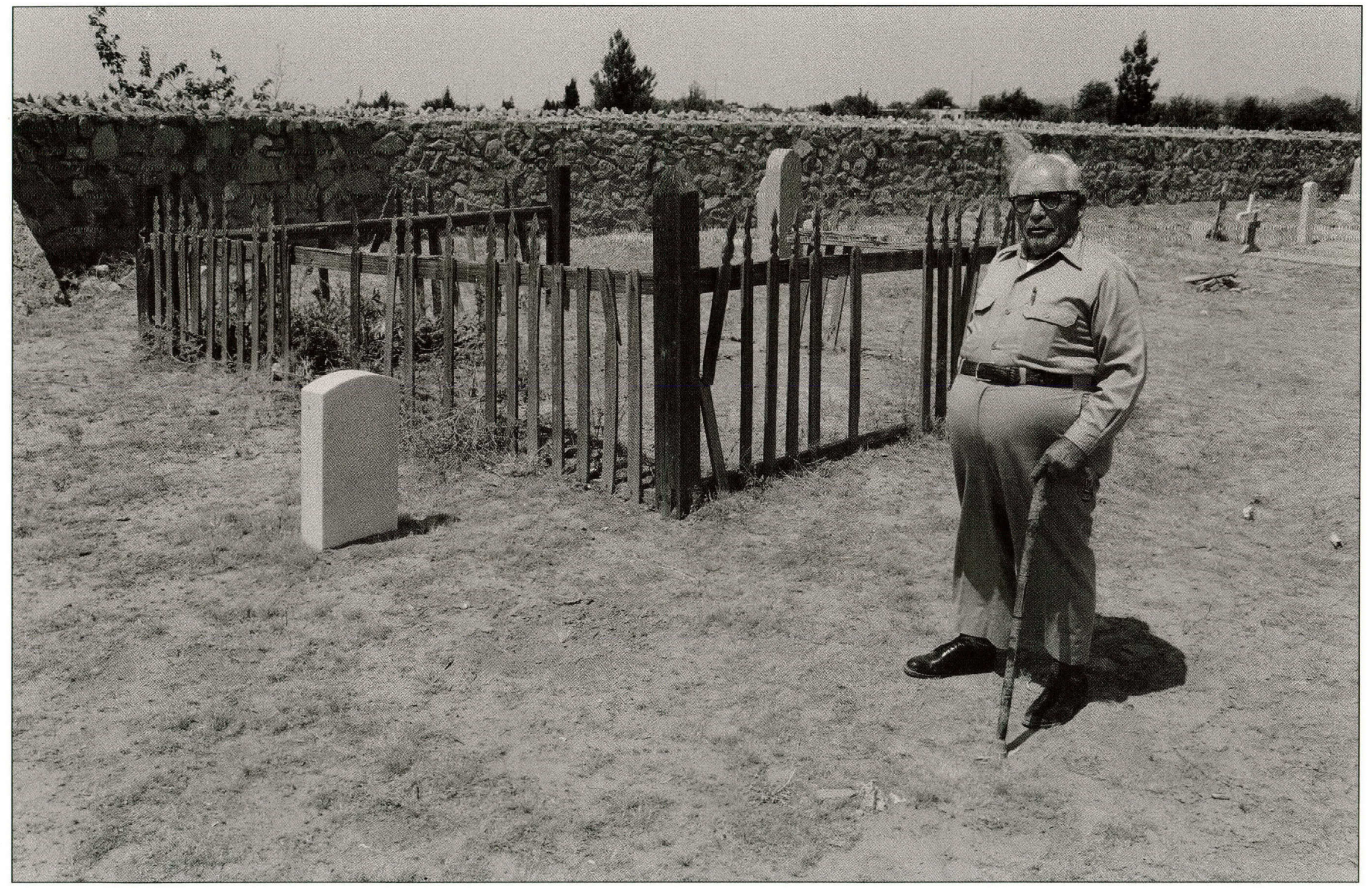


The location of the varas (willow branches) used in the whipping ceremony performed during the feast day of St. Anthony.

JOHNNY HISA AT THE RIO GRANDE 


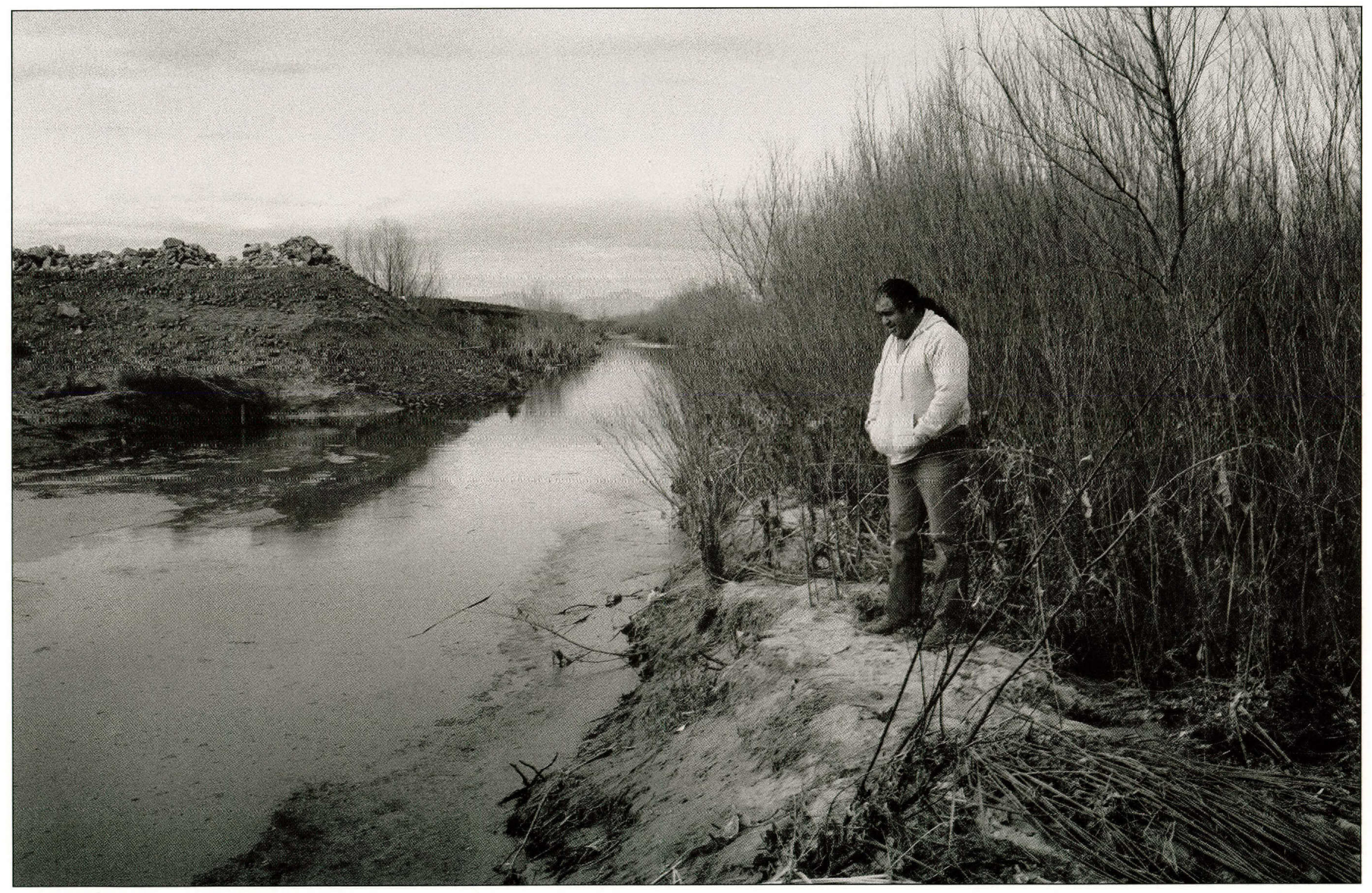


It's important that we maintain our bloodlines and relationships. The modern method is by last names coming from our father's side, but we are also a matrilineal society and maintain our relationships and identities through our mother's side. So the idea of maintaining the "Family Tree" is very important.

RAY APODACA,

GOVERNOR OF THE TIGUA TRIBE 1990-1992

Ray Apodaca 


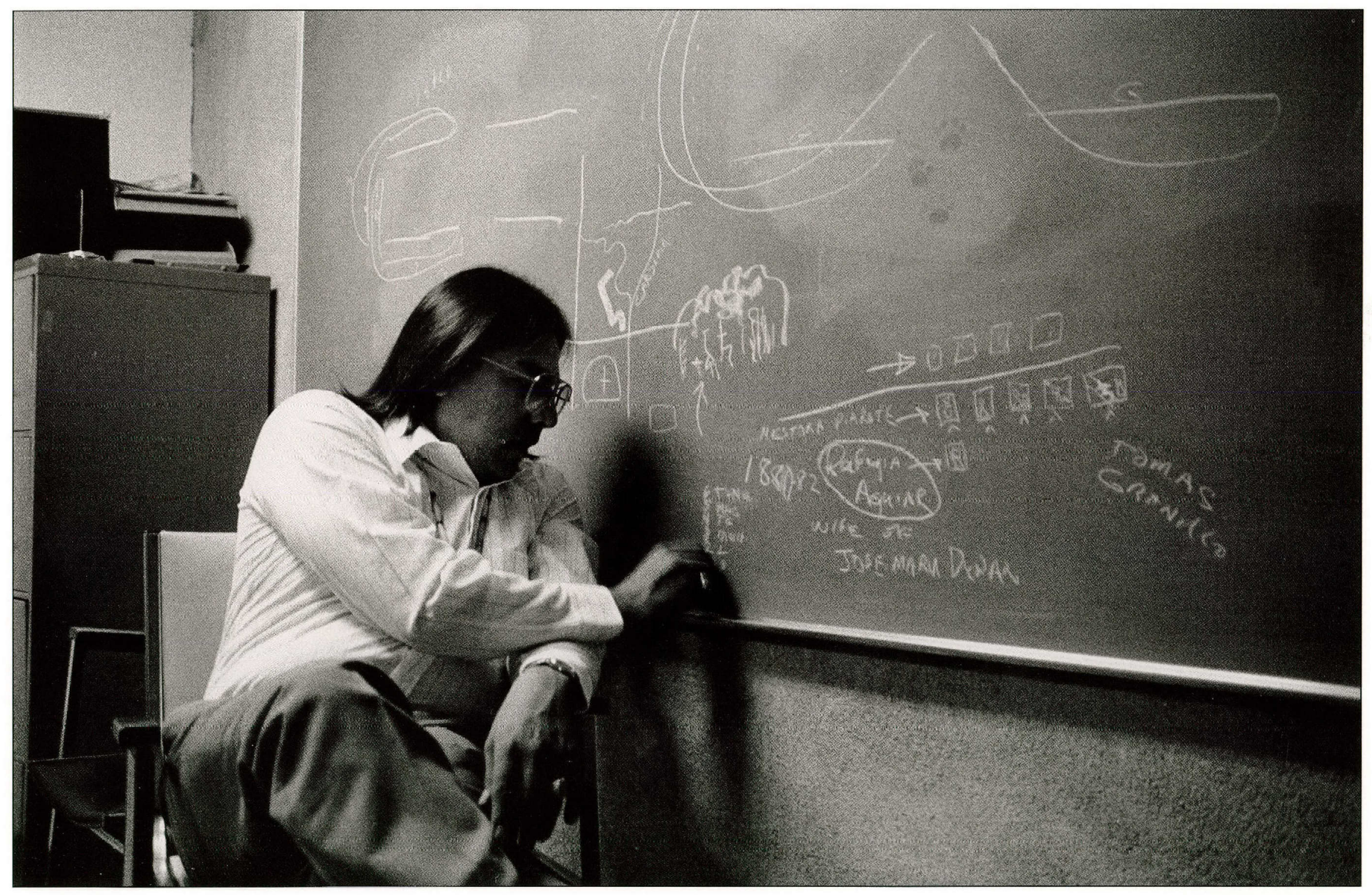


Three generations: grandmother, mother, and daughter. True Indian ladies. There are three generations we are looking at right there, sitting on the couch. Indian women...they have a way of getting things across to the community. Three generations of dancers right there, three ladies that can dance, and still dance.

Danny Archuleta 


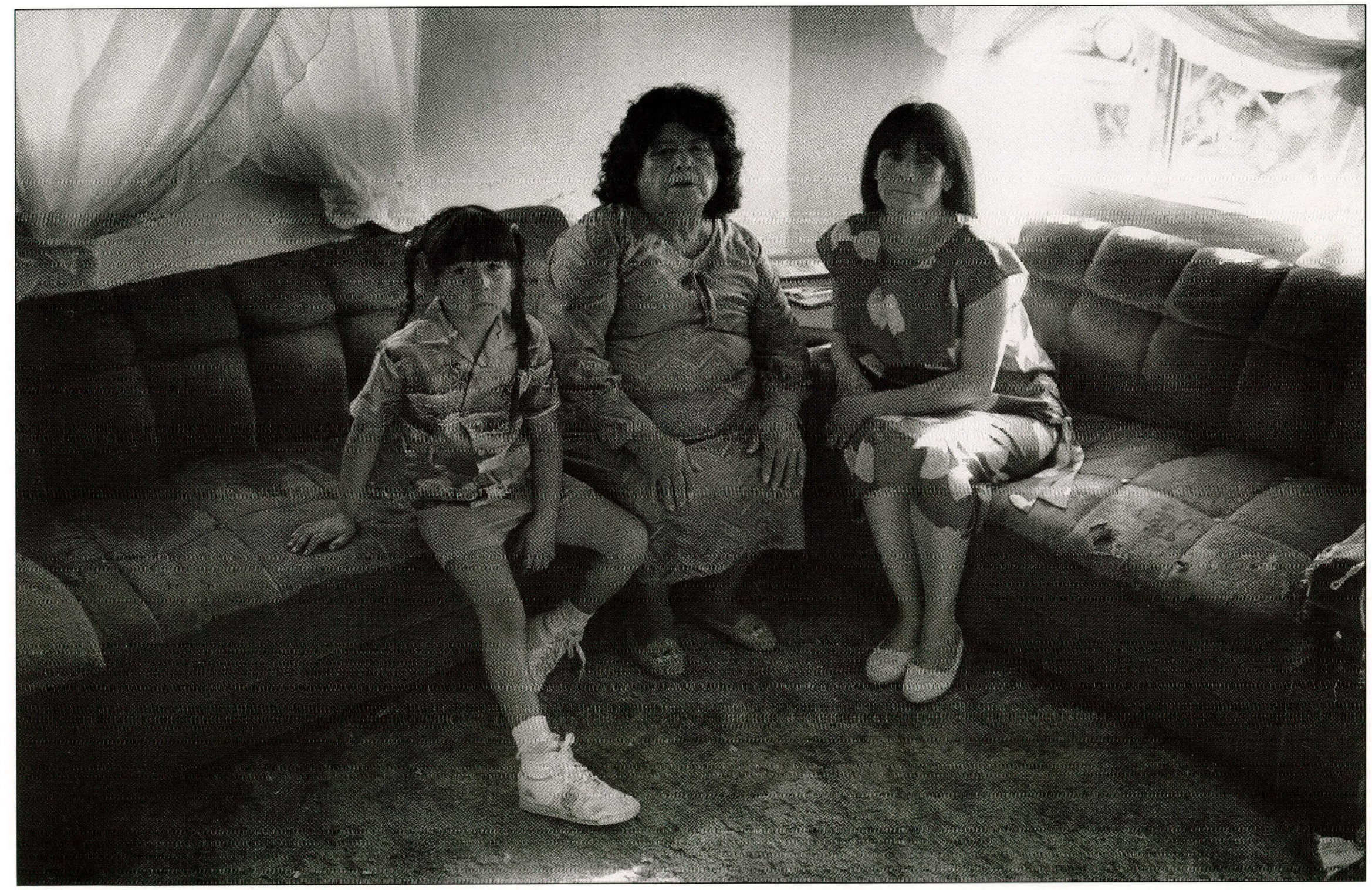


TRIBAL COUNCIL MEETING 


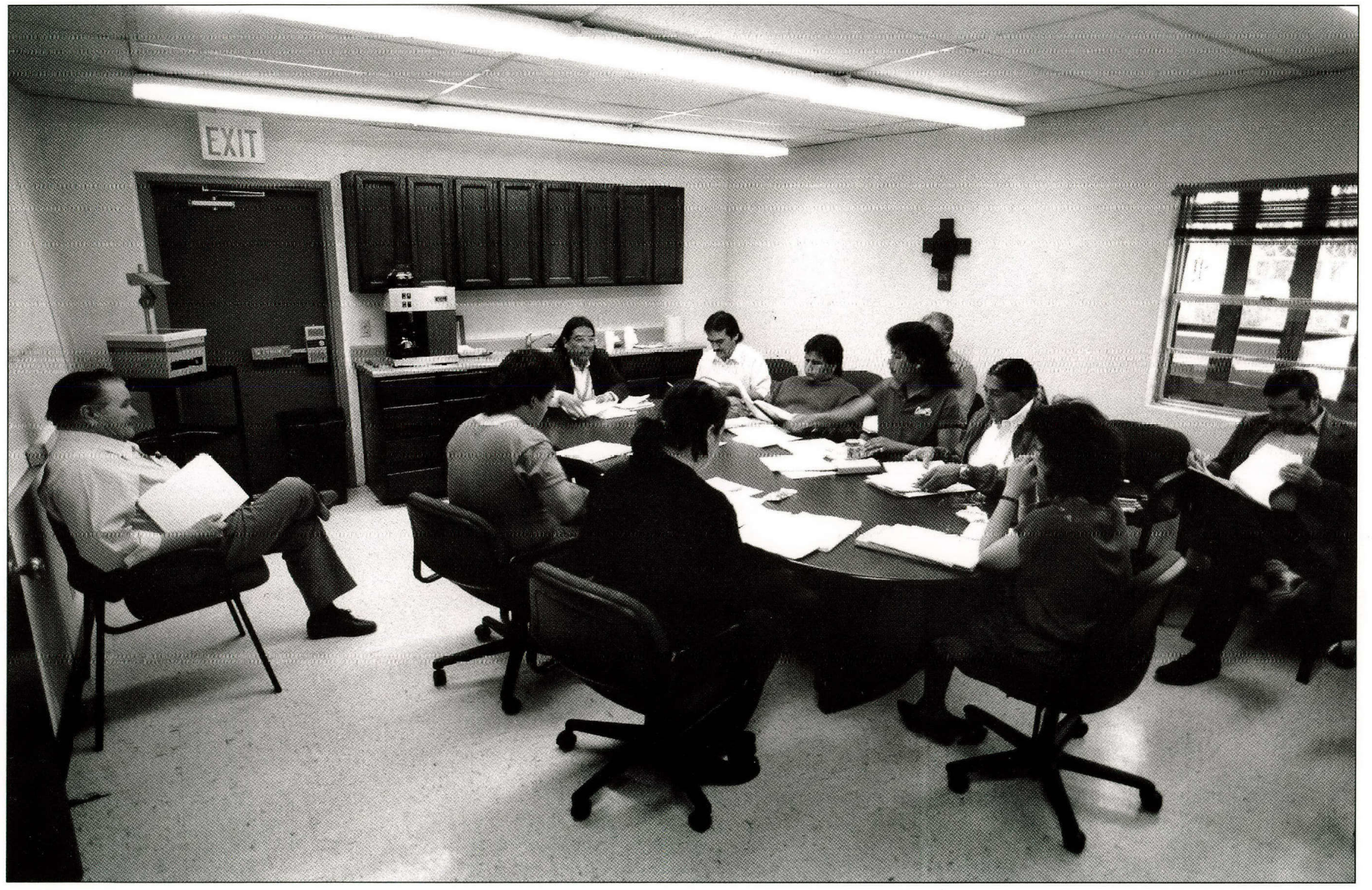


My family are just down-to-earth people. Everyday people. There is nothing complicated about either one of my parents.

My little brother at this moment is girl crazy. His grades are going down and we are pushing him. My goal in life is to get a degree in law or veterinary medicine. I intend to go into the cattle business. I like the outdoors, I am an outdoor person. I wanted to be an attorney, but I was told that if I became an attorney for any Indian tribe, I was going to be poor for the rest of my life, but I was going to enjoy what I was doing. I'm still debating that one.

Priscilla Hisa

I want to tell you something. Rosemary may not be Indian, but she has contributed much to the Indian families. I have much respect. She might not be Indian in blood, but she is full blood Indian when it comes to her heart. She has done more for our people then some of those Indian ladies that have lived all their lives in the community. 


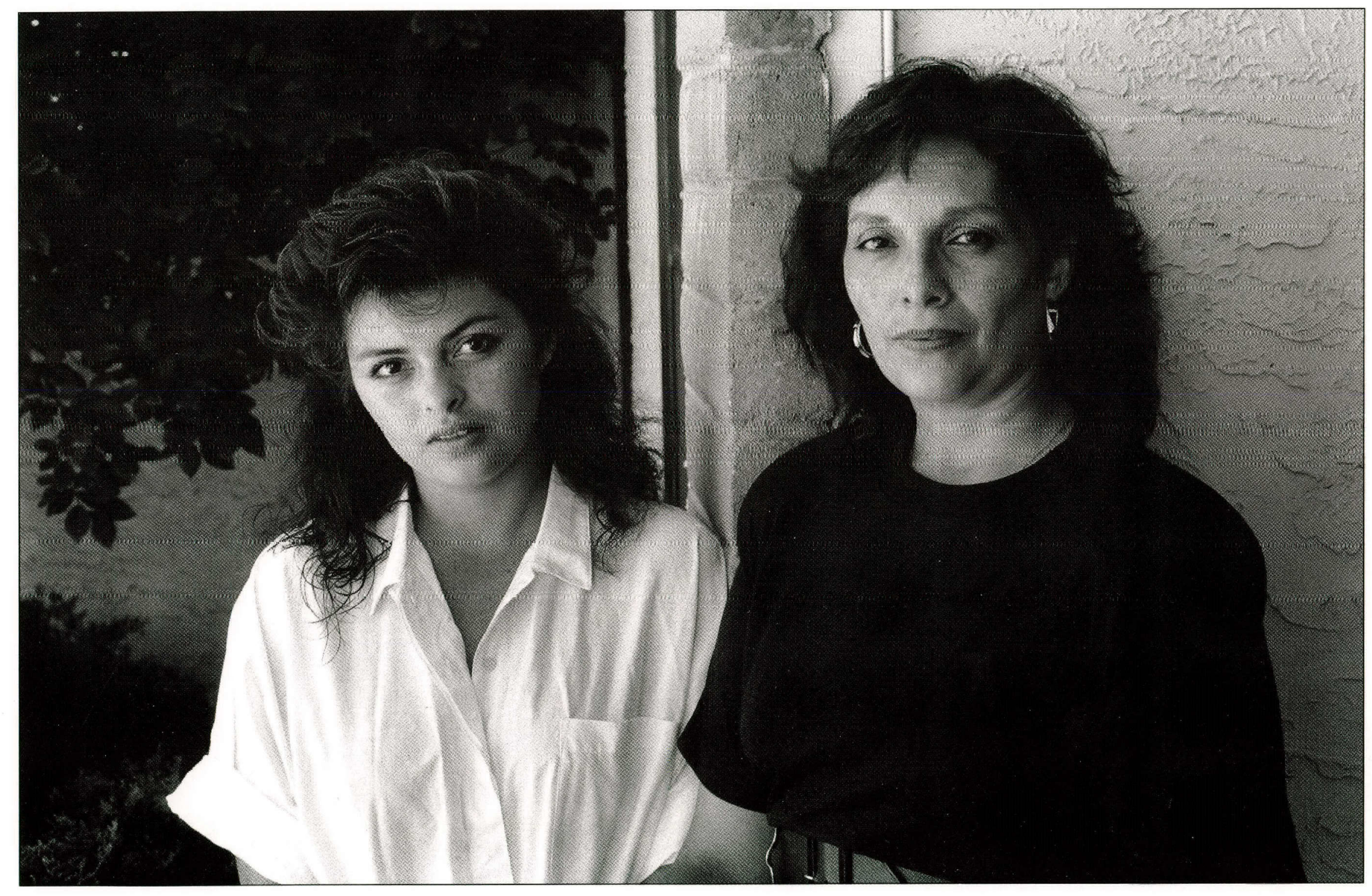


My Dad has lots of respect in the tribe. I want to be like him the way he makes lots of friends with different people. He's rea friendly till someone makes him mad!

My brother died because of drugs and stuff. There are problems with drugs and alcohol. I have friends that are in the reservation that tell me they want to be doctors, lawyers, and they are doing drugs and stuff like that. If I could say something to kids in the future, I would say not to get involved with trouble here in the tribe.

I would like to go to Notre Dame and become a coroner or a plastic surgeon. I think it's interesting the way they do facelifts and stuff!

Patrick Hisa

You see John here with his son, Patrick. John is a very strong individual. He is a very respected man in the community. He is very much for the people. I like these folks, I like them a lot. They make our reservation just go that much better. They find ways to make things work. They are such great folks, they are good. Patrick and Priscilla are just great, to have kids like that is just something else.
This year, Patrick was very proud because it was his first year to go into the election building, where the elections were held. He had never been there. Last year Patrick asked Johnny if he could go with him. Johnny said, "No, you are not ready." This year he said, "Well, you are ready." Also, this year he partook in a ceremony after all the dances are finished. He had never done this before. He couldn't really tell me in detail what happened because of my non-Indian status. But from stories that I hear, Johnny and my mother-in-law, I more or less know. To him that was an honor. He was very honored that Ray and the other tribal leaders took him and other youths with them.

Rosemary Hisa
PATRICK HISA AND HIS FATHER, JOHNNY

Danny Archuleta 


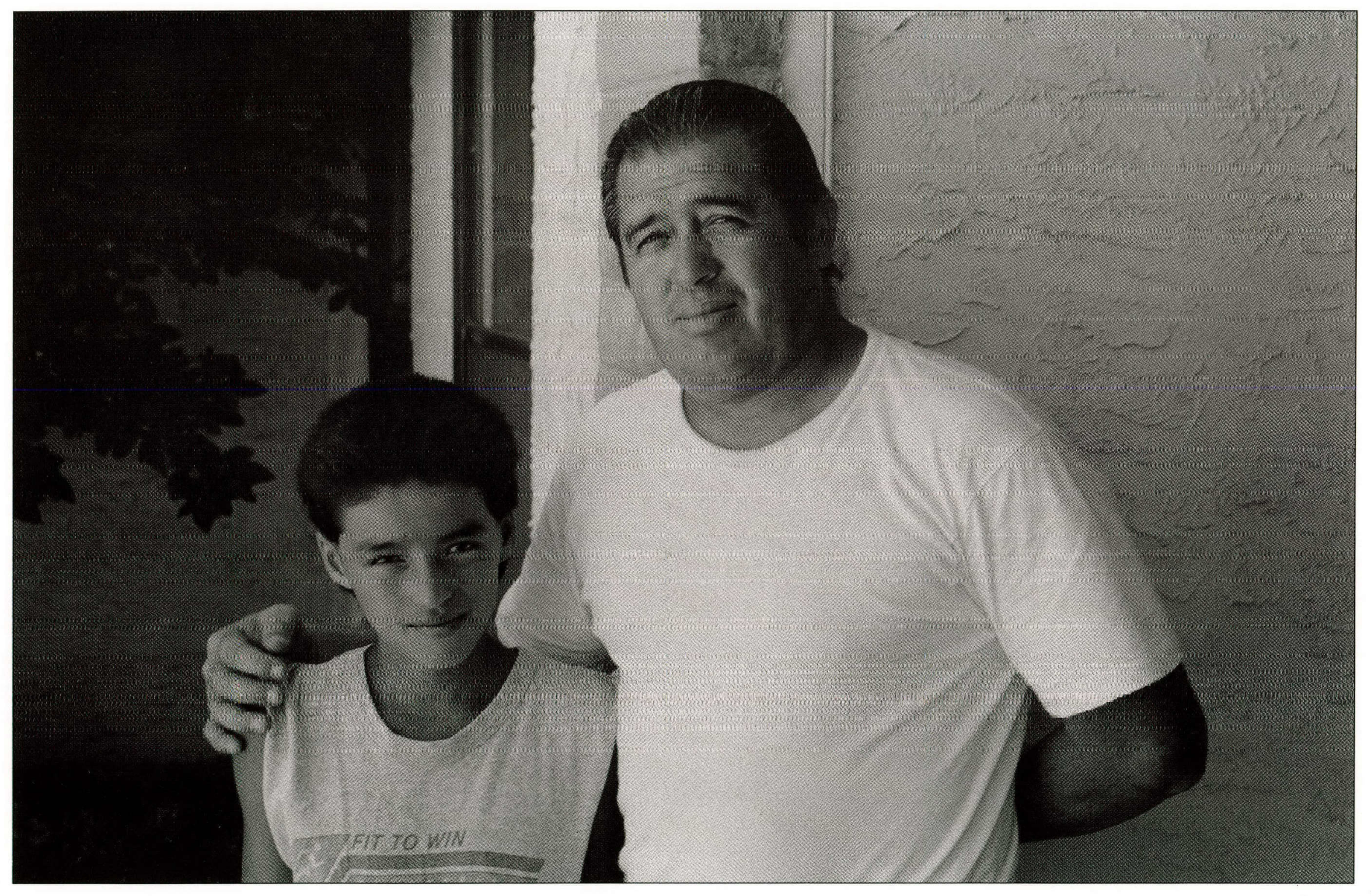


Ramona is the oldest woman in the tribe. She remembers the old days when she went hunting with the men and until recently, she lived in the Old Pueblo with only a wood

burning stove for cooking. Today she stays with relatives.

She was born in 1900

Here is a picture of my great-grandmother. Ramona Paiz. Her birthday is in November. I believe it is November 4, and she will be ninety-two. Ninety-two years old! She is something else. I think she is the oldest living elder of the pueblo.

Danny Archuleta 


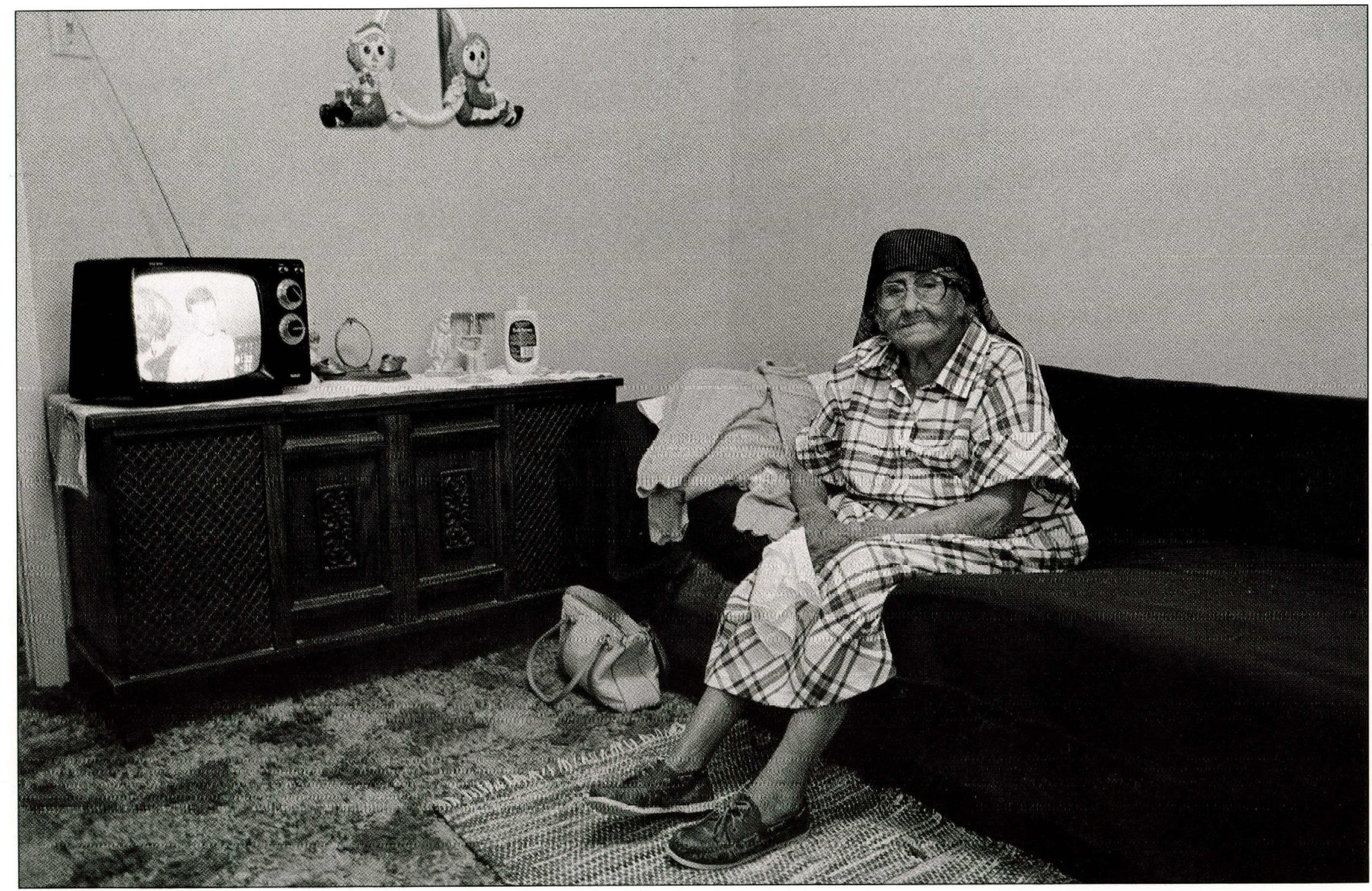


The shirt, probably buffalo skin (according to the University of Arizona), was hidden for years in a pigeon coop. It is tinted green, has hand beaded seams and is detailed with a round mirror and ribbons possibly from an old military medal.
DAMASIO COLMENERO'S TOLECO (WAR SHIRT) HELD BY MIGUEL PEDRAZA, JR. 


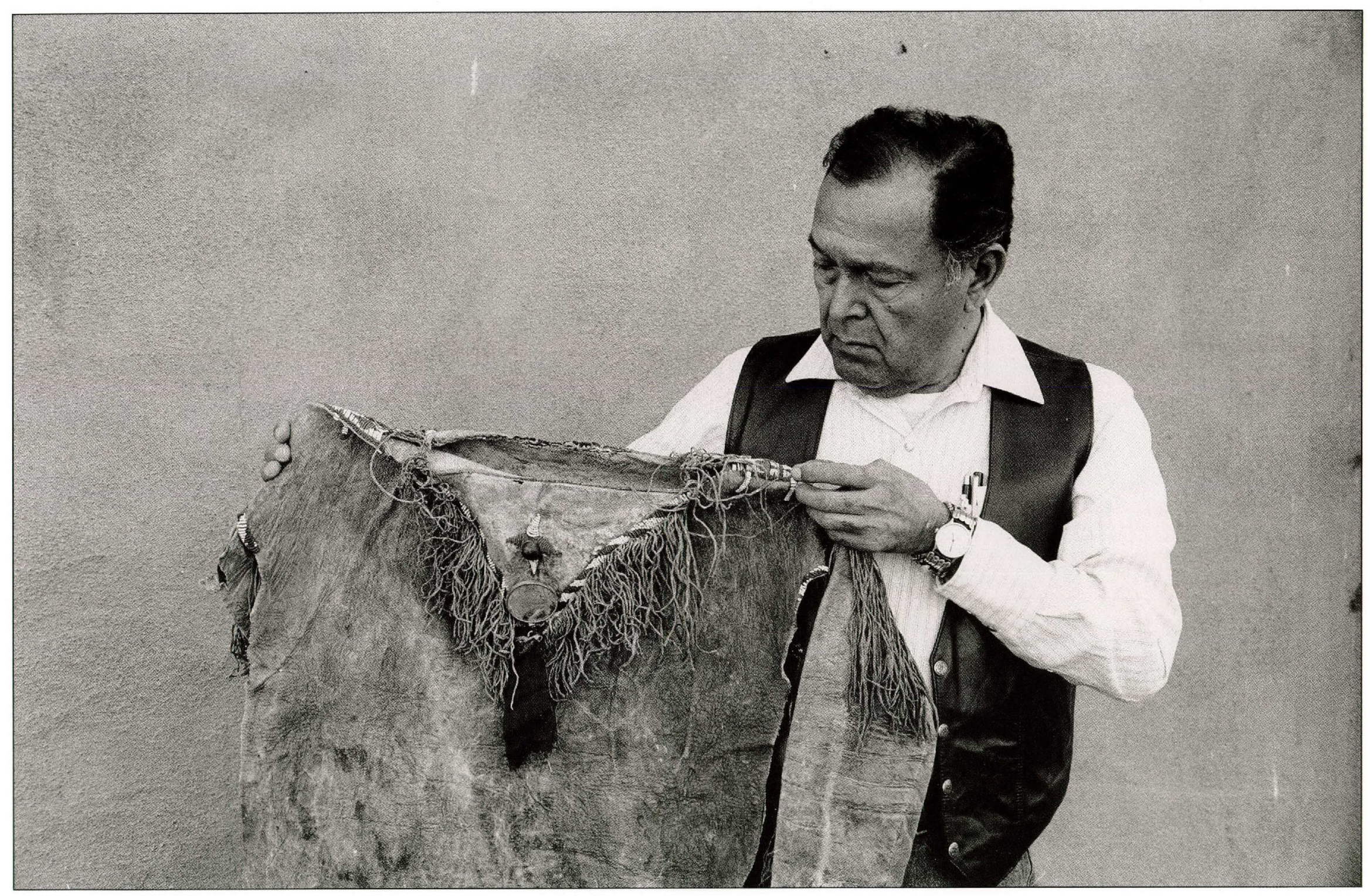


JUANA AND SEVERO ALVIDREZ HOLDING FRAMED PICTURE OF SAINT ANTHONY 


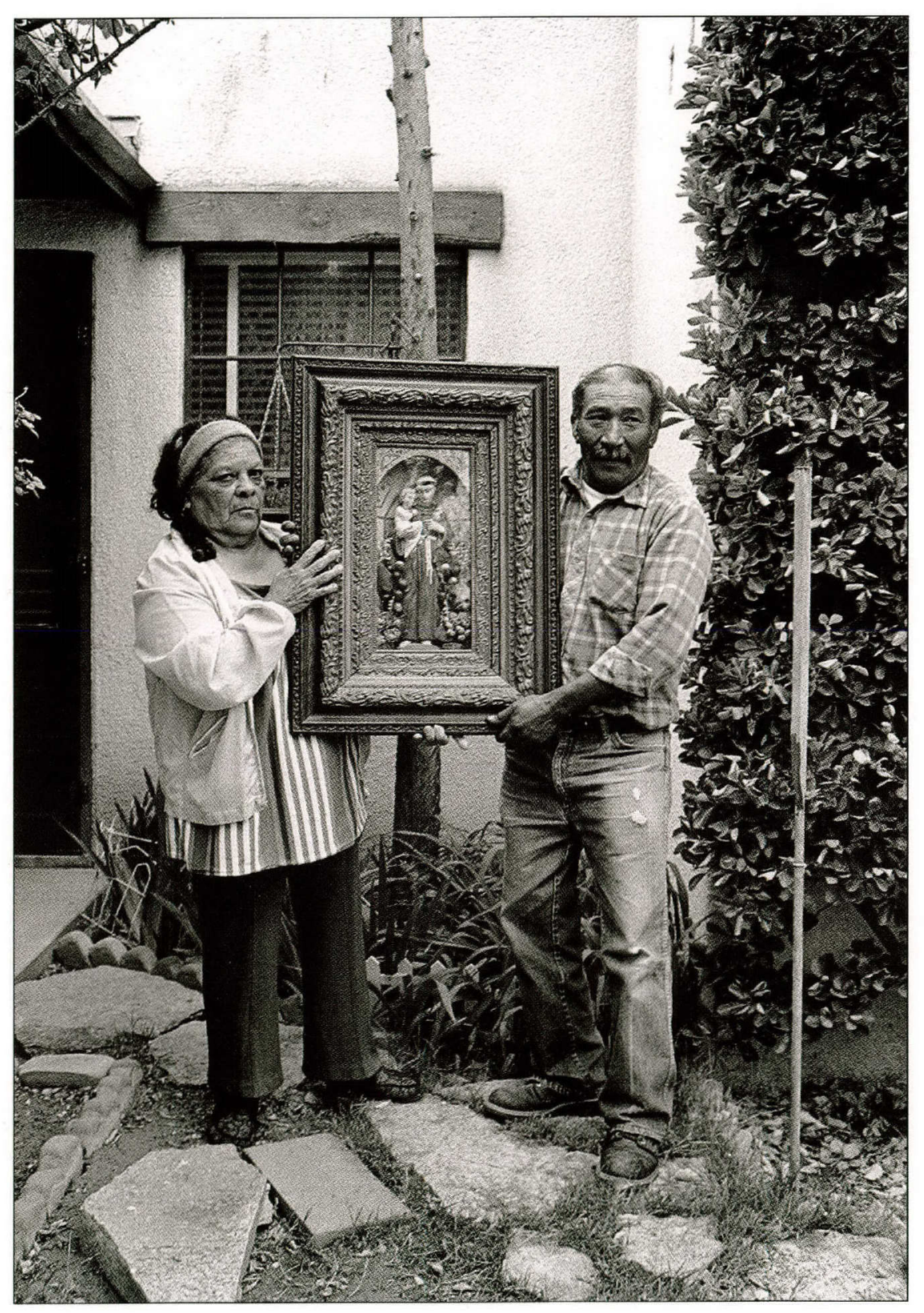


LAWRENCE LUIAN

IN HIS BEDROOM 


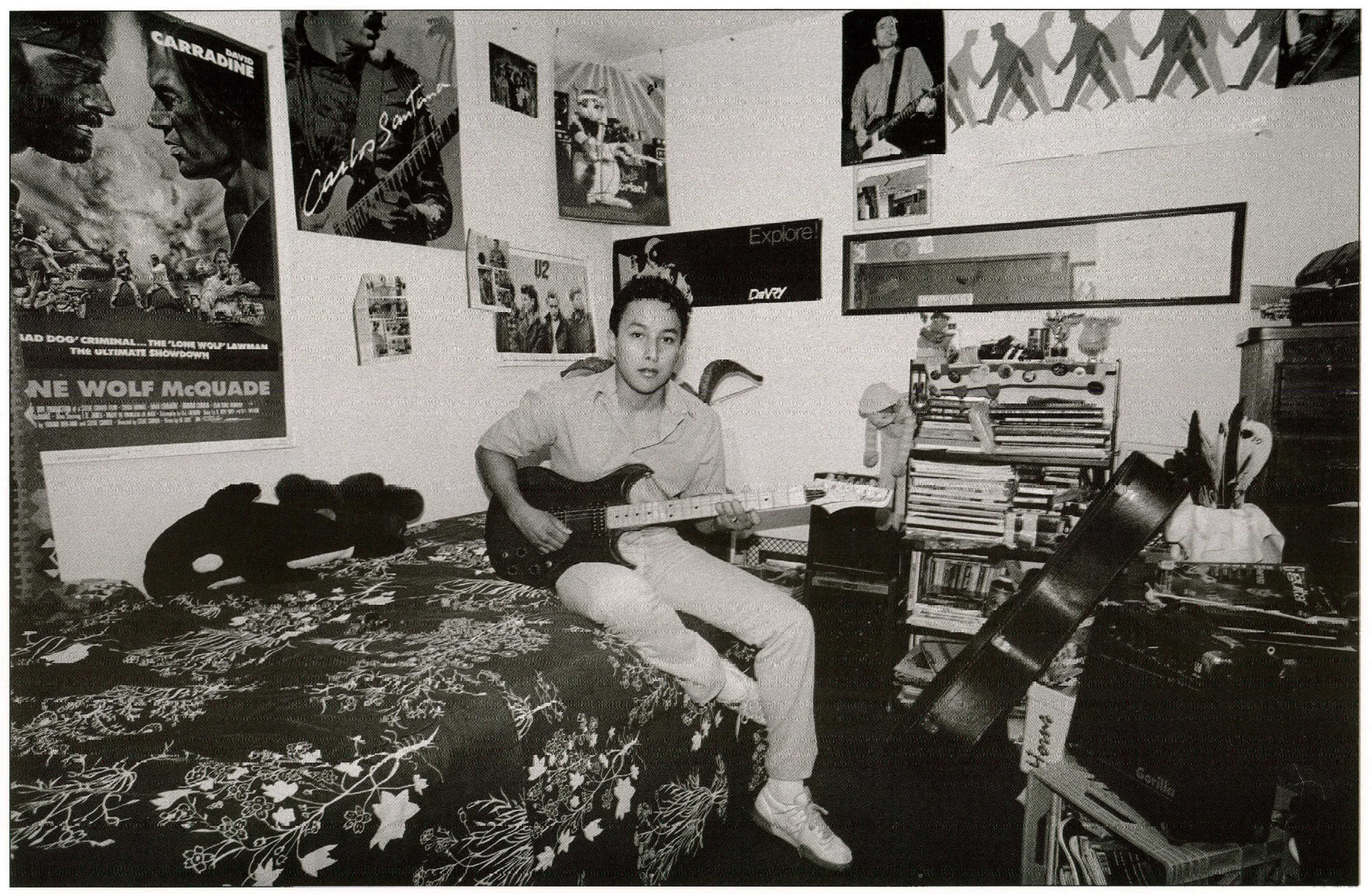


GRACE GOMEZ

PAINTING POTTERY 


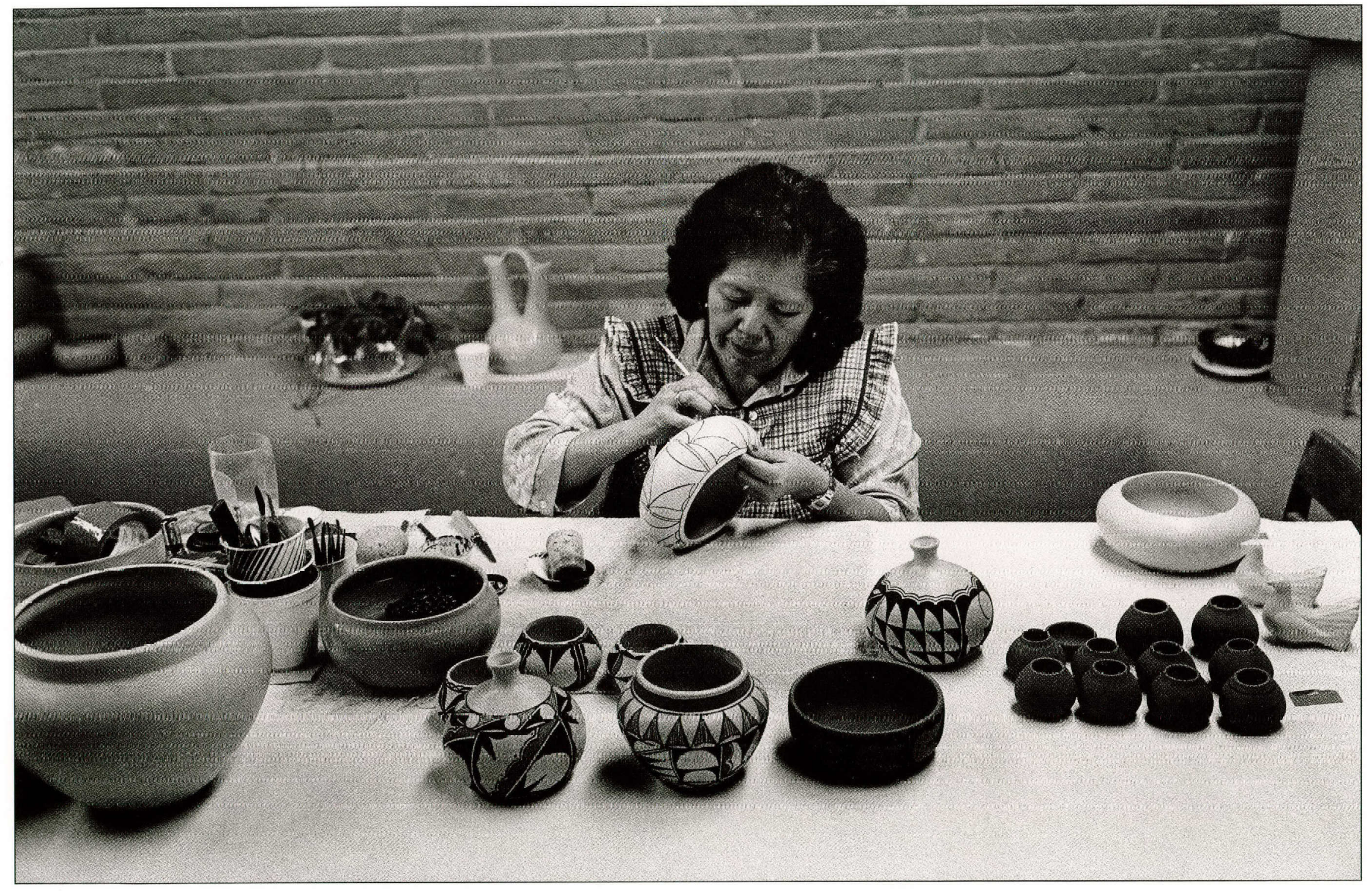


CARMEN BENAVIDEZ CALVERT AND HER BABY, NICHOLE MARIE 


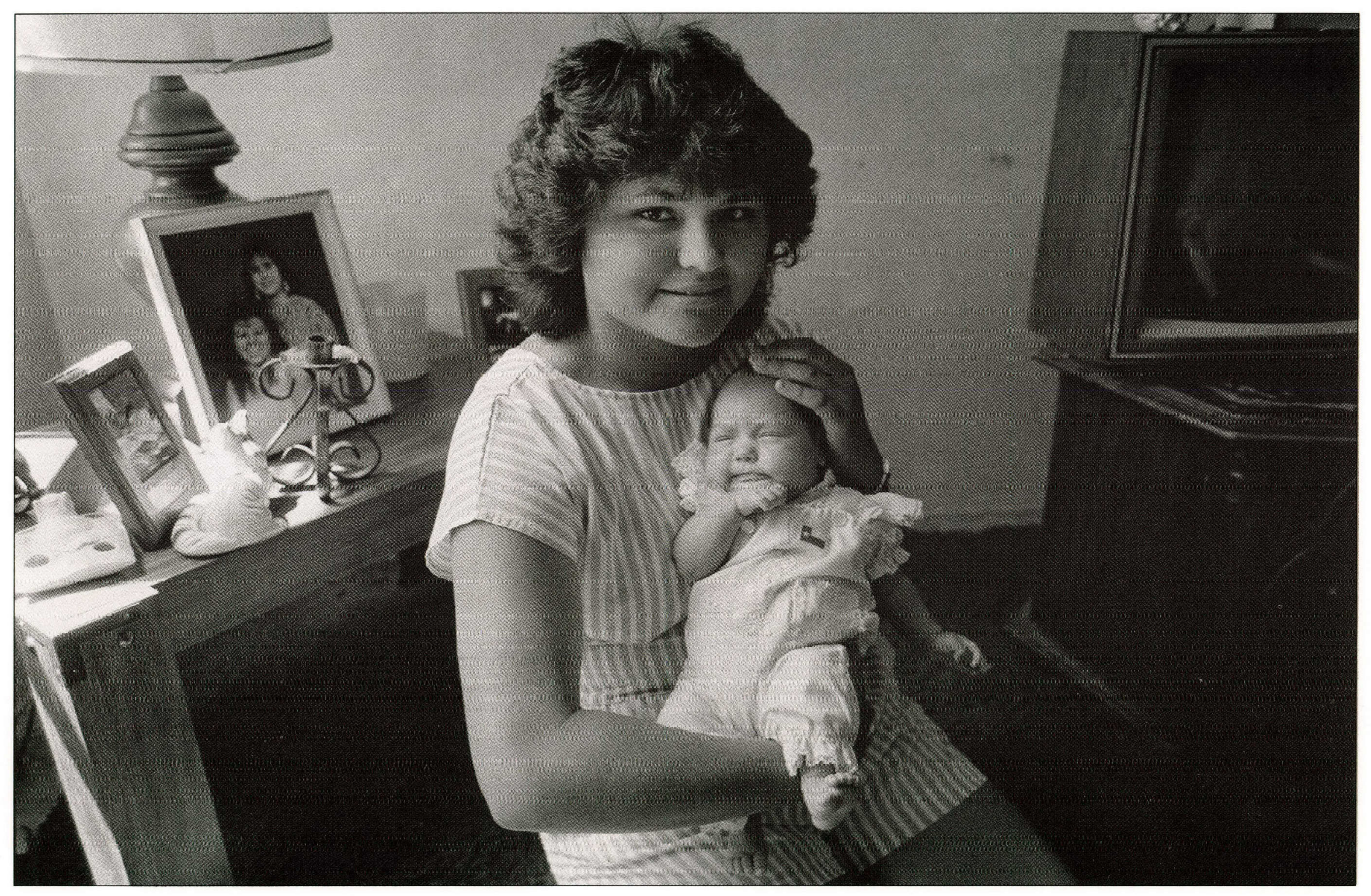


HISPANIC AND TIGUA CHILDREN

IN THE PLAYGROUND NEAR OUR LADY OF MT. CARMEL MISSION 


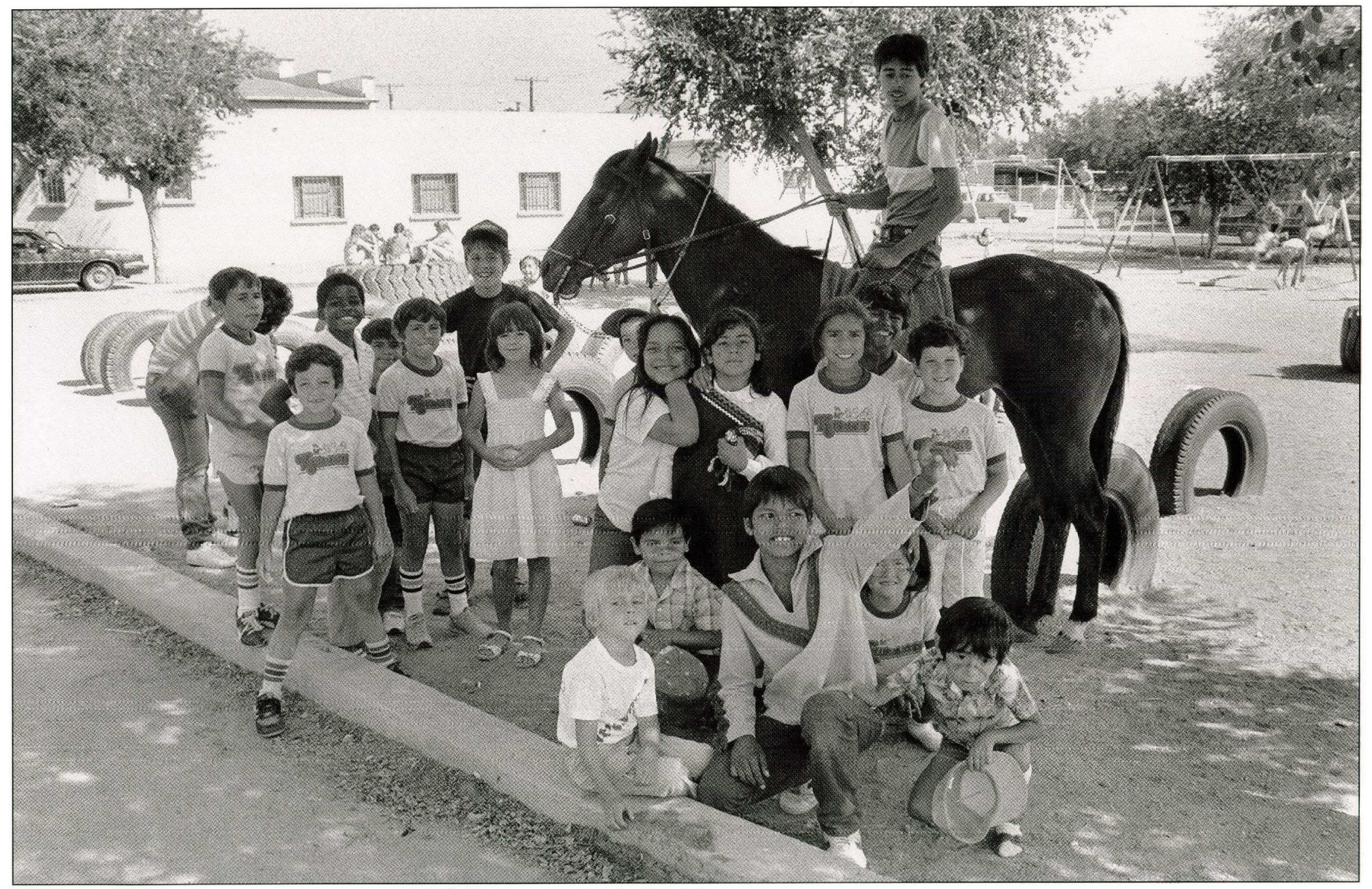


The children's teacher is Julie Soto. Julie says that today children are more aggressive because of the Ninja Turtle fad. She said her supervisor told her to be careful of permitting racist remarks among her class of mixed students. "Don't let anyone say: Just sit down like an Indian!"

This was my classroom, when I taught that Title 5 Indian education program. Boy, did I love those kids! They were just so much fun. Those kids are something else. They keep you on your toes. To share some of the traditional stories and tribal ways and lifestyle and what have you is always well worth the while. They would learn, respond, and react.

Danny Archuleta 


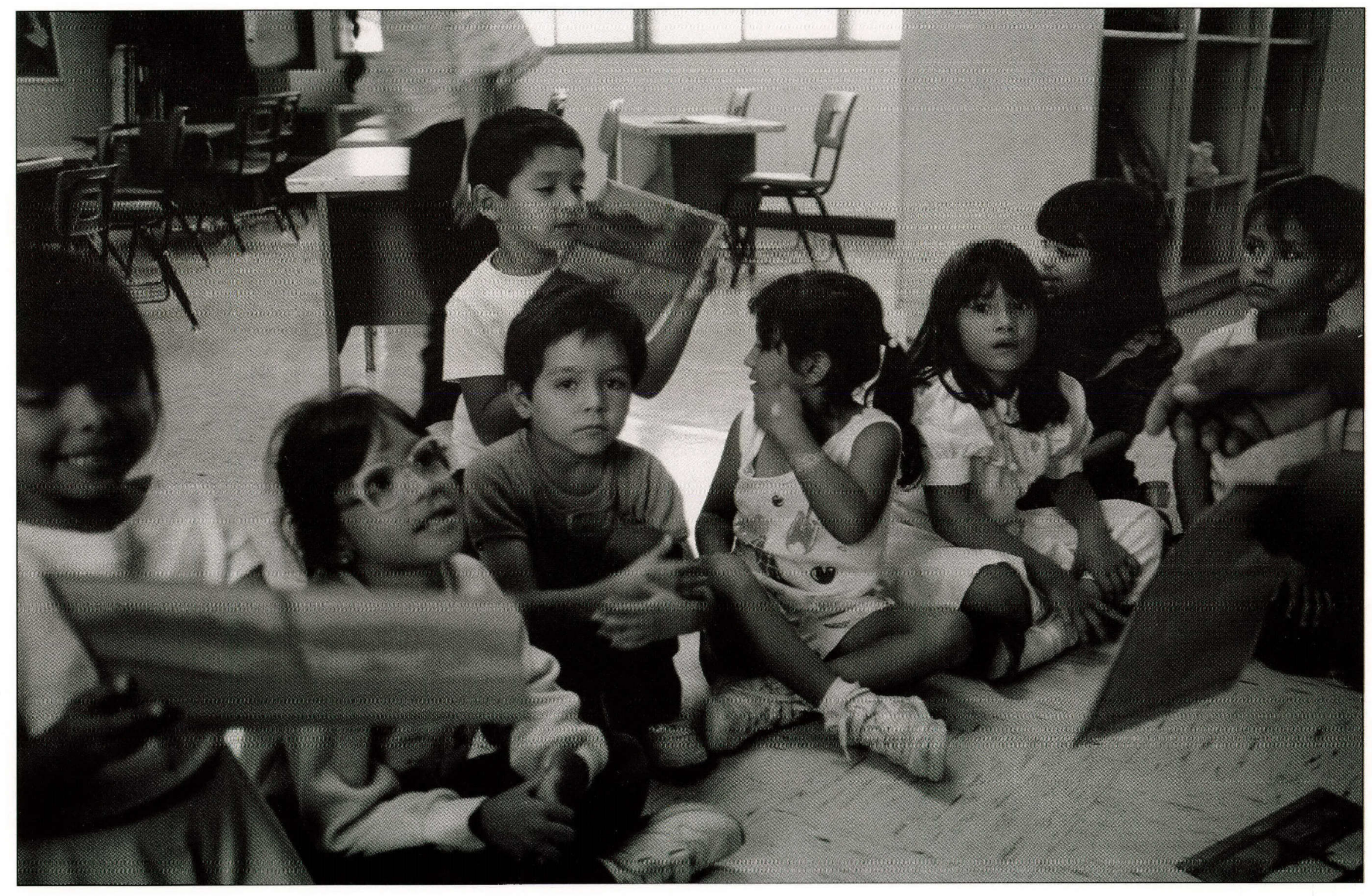


Many children are not being taught, because their parents don't realize the importance of it. They just don't see it as a vital part of their lives. They, themselves, have not been that close to the pueblo, therefore, they don't think that it is important for their children to be close to the pueblo. I know for instance, Joe Sierra, with his grandchildren and Johnny with his children.

I remember my mother-in-law with my children. She used to tell them that without their support, without them taking care of the pueblo, the pueblo would not exist. They would not be special. Since they were small, they have made them see how special it is, and how important it is to carry these traditions. The way my mother-in-law used to see it, when I first got married to Johnny, she told me how involved they were with the pueblo, and that she hoped that I would not interfere with that, or that I would not take Johnny away from doing that. Because to them that was a number one priority. She used to tell me that, if they didn't do that, the pueblo would just dissolve itself. It would have no meaning. They felt that it was very important to teach what their ancestors had taught them. For them to teach those same teachings to the young ones, their children. She would say that it was very important for them to find out where they came from and how they came to be here. Teaching the little ones what to do, even to start dancing at a very young age. I think that now, I see more young children getting involved than used to be. Also, you must understand that a lot of these people were not aware that they were Indians, or not aware of a lot of traditions and customs, because they went through a period where they were ridiculed and laughed at. My mother-in-law used to tell me that they went through very hard times. Some Indians would rather be recognized as a Mexican than be ridi- culed like the Indians are. A lot of them would not say they were Indians. In our family, Johnny keeps everyone informed about everything. Johnny gave his two brothers that live in California, a drum. When Johnny goes over there, they will chant with the drum. The kids, we have sent them recordings. Now their kids are doing it over there. Their grandfather, Johnny's brother, has a drum. When they go over, all of them just sit around him and he will start chanting on the drum. He puts the tapes on. Vince can now do it. He is so cute, because he tells his other cousins on his dad's side, his mom is the Indian. So he tells his family that he is a Texas Indian in California. Elena was saying that one time, they asked him "What do you mean by that?" He says, “Well, I'm an Indian from Texas, but I'm stuck here in California."
THE GRANDSONS OF

GEORGE ATTWOOD,

A TRIBAL MEMBER FROM

VICTORVILLE, CALIFORNIA 


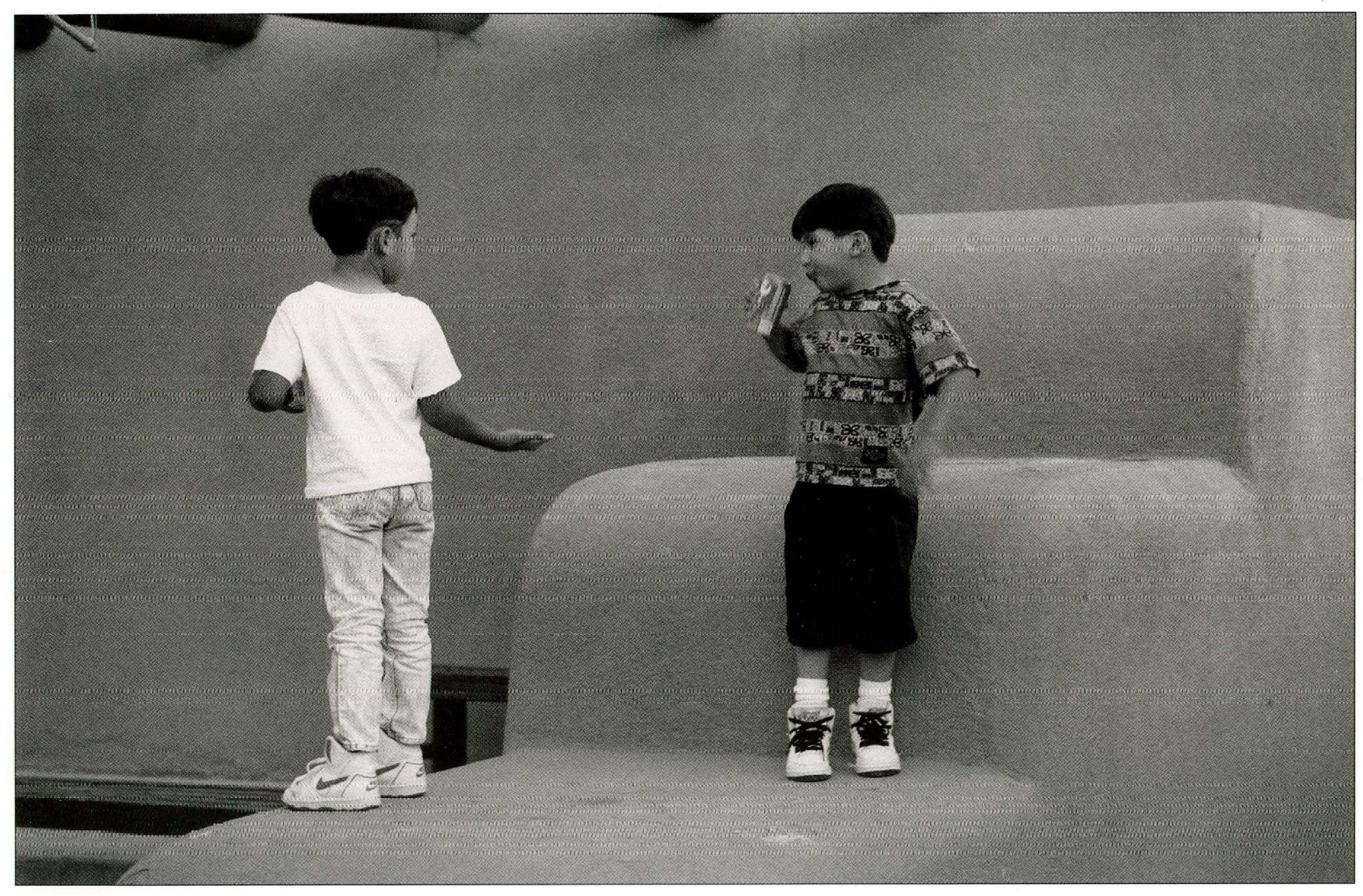


On the feast day after the morning dances and celebrations at the church, the celebrants walk to the Tigua Activity Center near the church, where a public meal is served without charge to the community. All are welcome regardless of tribal affiliation.

They are in charge of serving as stewards, the mayordomos. It is a heck of a responsibility. They are the ones that are in charge. Not just them, but whoever the stewards are, are making sure that all of the food is prepared.

LUIS AND MARY LOU SILVAS AND THEIR FAMILY AT THE TIGUA ARTS AND CRAFTS CENTER, PREPARING THE MEAL FOR THE ST. ANTHONY'S DAY FEAST

Danny Archuleta 


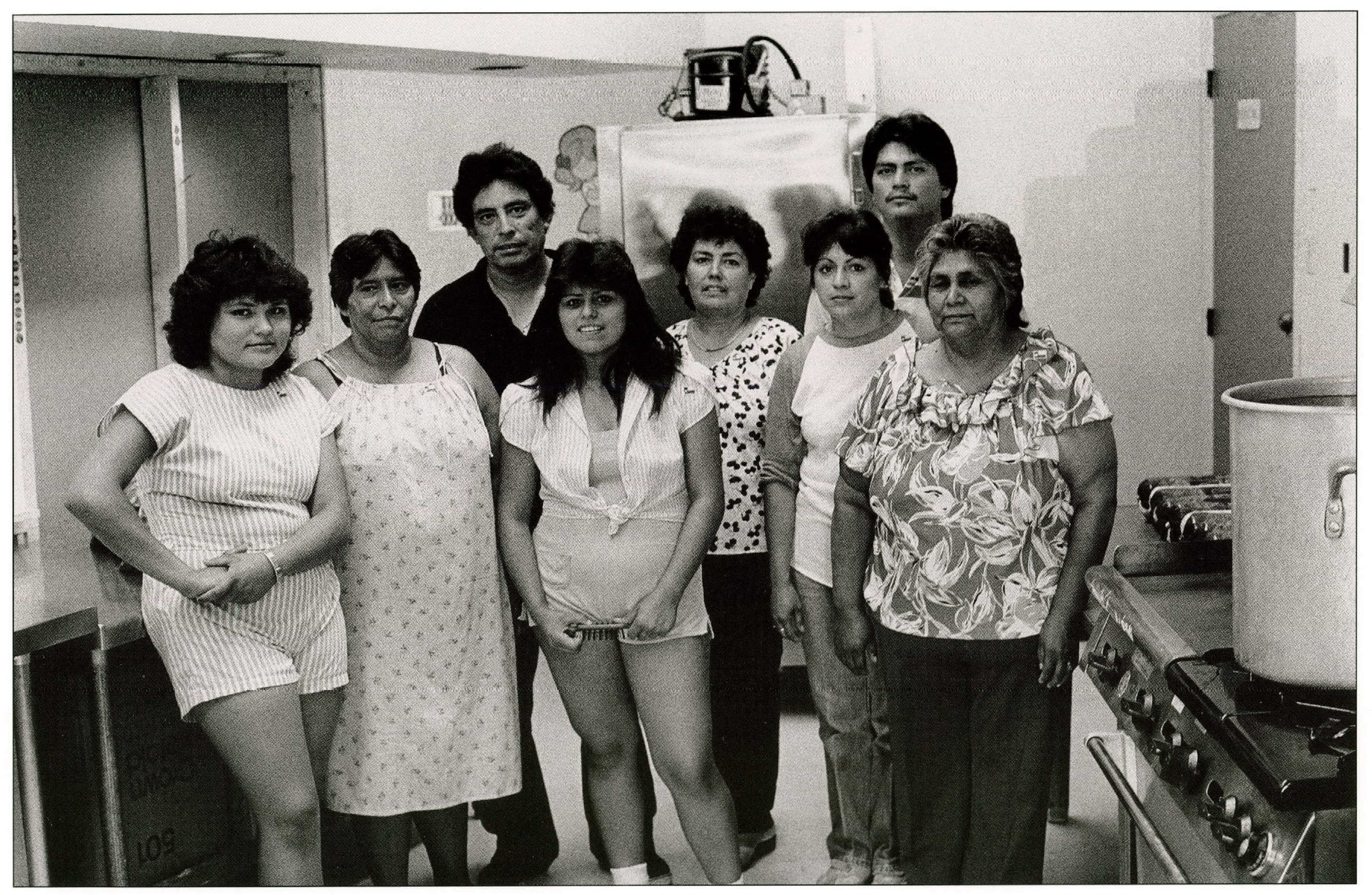


Priscilla prepares for her wedding. She feels sad about the future of the tribe.

Someday we are going to run out of blood. My blood quantum is one-eighth. The government says that after one-eighth, you are no longer a member of the tribe. Everybody my age is one-eighth, and we are the ones next in line to run the tribal government. After us, who is going to do it? The government has made us history....We helped them slash our own throat!

Priscilla Hisa 


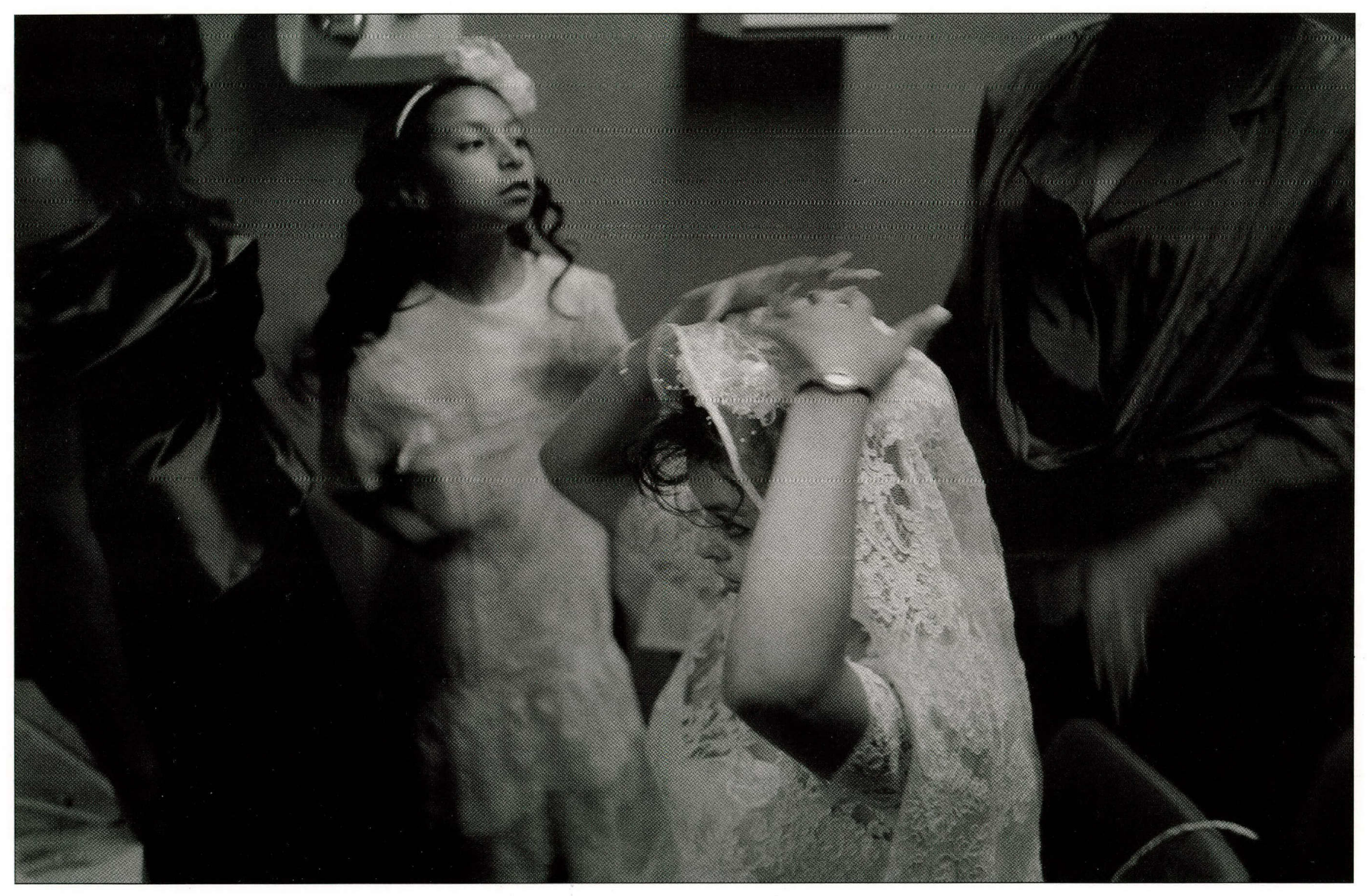


The service was conducted by the Catholic priest for the Catholic part of the service and by Ray Apodaca, the tribal governor, for the Native American part of the service.

What my husband is holding here is an Indian blanket. In the Mexican culture, you know they call it the laso. It is like this rope with a cross. It is kind of like a long rosary. But it is huge. You put it over both couples to unite them. What I am holding is a shawl. It was given to me by my uncles. It kind of stands as good luck and signifies you are now a part of his family, but remember you are one of us too.....My maid of honor, Charlene, is holding the rain sash. She is also holding the wedding basket. The rain sash and the wedding basket were gifts from Governor Apodaca. The rain sash works like the wedding rings do. You hold hands and they tie your hands together. Saying o.k., you have said your vows, you are now married. The wedding basket has eagle fluff in the center. That is given to every couple that is married. That is for good luck.
Back in the old days, what used to happen was that the bride would go and stay at her fiance's parents' house for a while. All she would do night and day was grind corn. Then she would present it to the mother. That happened for four days, signifying the four seasons. Then afterwards, his mother saves the cornmeal in little pottery jars. Towards the end, when the wedding basket is presented to the couple, I give his mom the four little vases full of cornmeal. She puts them like the sign of the cross going the four directions. Saying that she wishes us well and she wishes that we never go in hunger. It is kind of like praying. You know how they say that Native Americans pray to all directions. They pray to all things that are in those directions. So it is kind of similar to that. You can't see the wedding vase that the best man is holding. It is a little funny vase. It has a handle on top and two hands. Traditionally, you are supposed to drink out of that, saying that you are two individuals, but yet you have formed one family now. This is what all this signifies.
WEDDING OF PRISCILLA HISA AND FRANK LUEVANOS 8 JUNE, 1991 


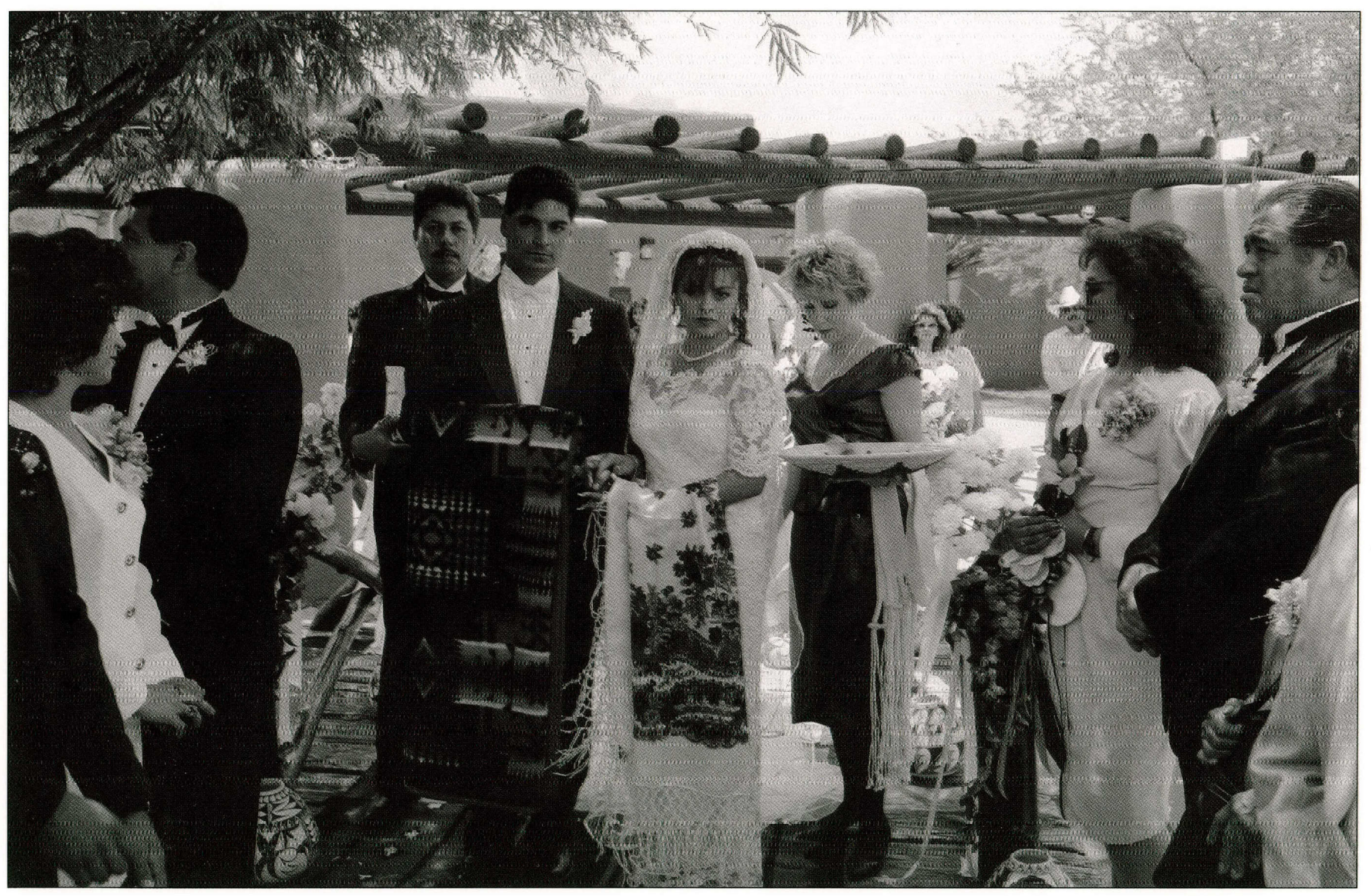


The cacique or religious leader of the tribe is elected by the tribal council and serves for life.

THE FORMER CACIQUE, TRINIDAD GRANILLO (1909-1989) 


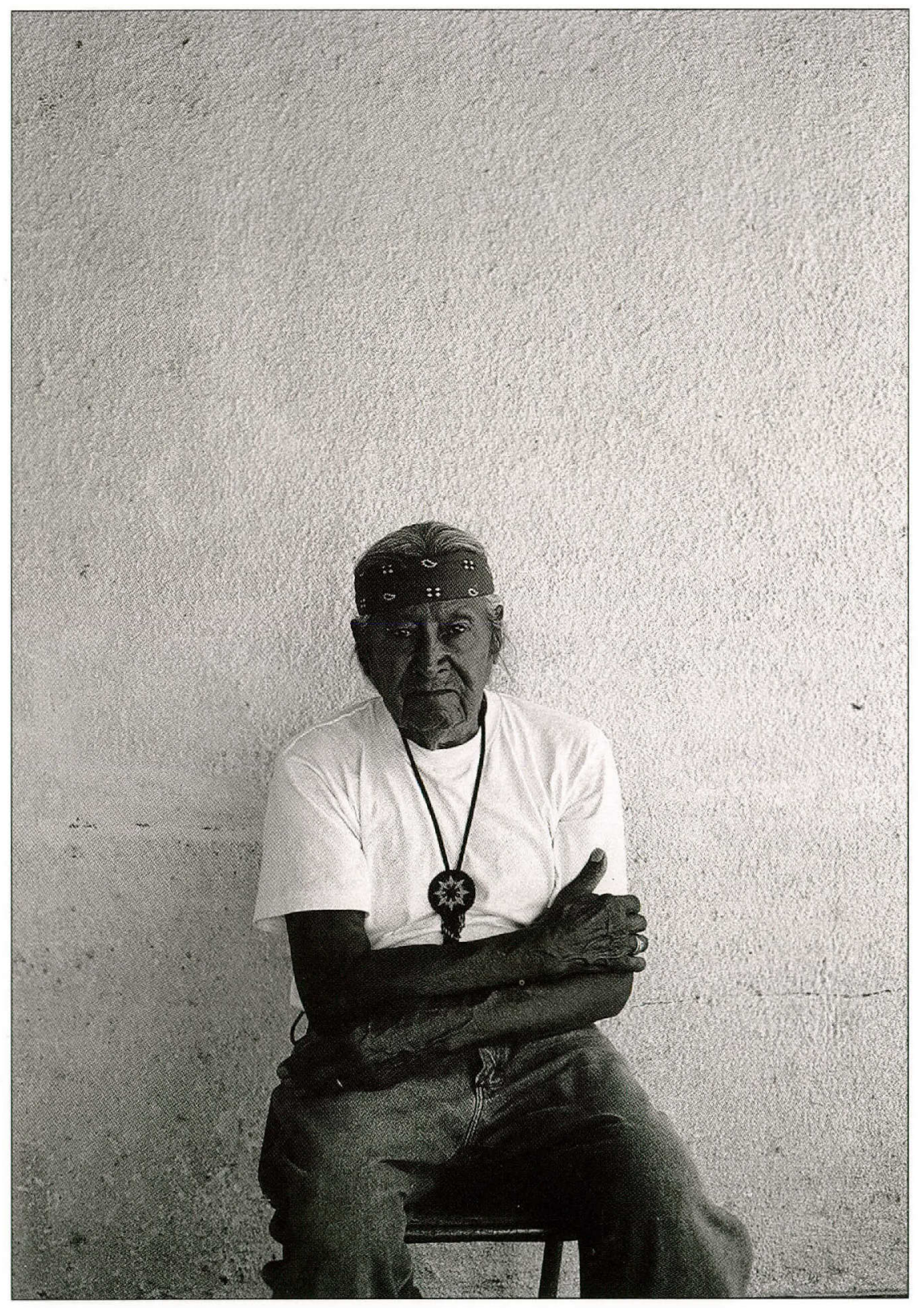


Herminia has taught many in the tribe how to make the Indian bread baked in the hornos (adobe ovens). "Who will bake the bread when you are old?" she was asked. "My daughter-in-law and my son are baking the bread now," she said. "But it is not quite as good. It is all in the hands. They mix the correct ingredients, but it is in the hands."

Herminia Silvas is holding the bread that she bakes. She is so proud. You know she is one heck of a bread baker. It reminds me of the year that $\mathrm{I}$ had the responsibility of preparing the food for the feast day. She just helped me out so much. We had to make so much bread, it is not even funny. But she just bakes bread and bakes bread, using those simple ingredients, salt, yeast, flour, lard, and water. Combining all these things together, she uses that old adobe oven, with the mesquite, and just bakes away. She is so proud. 


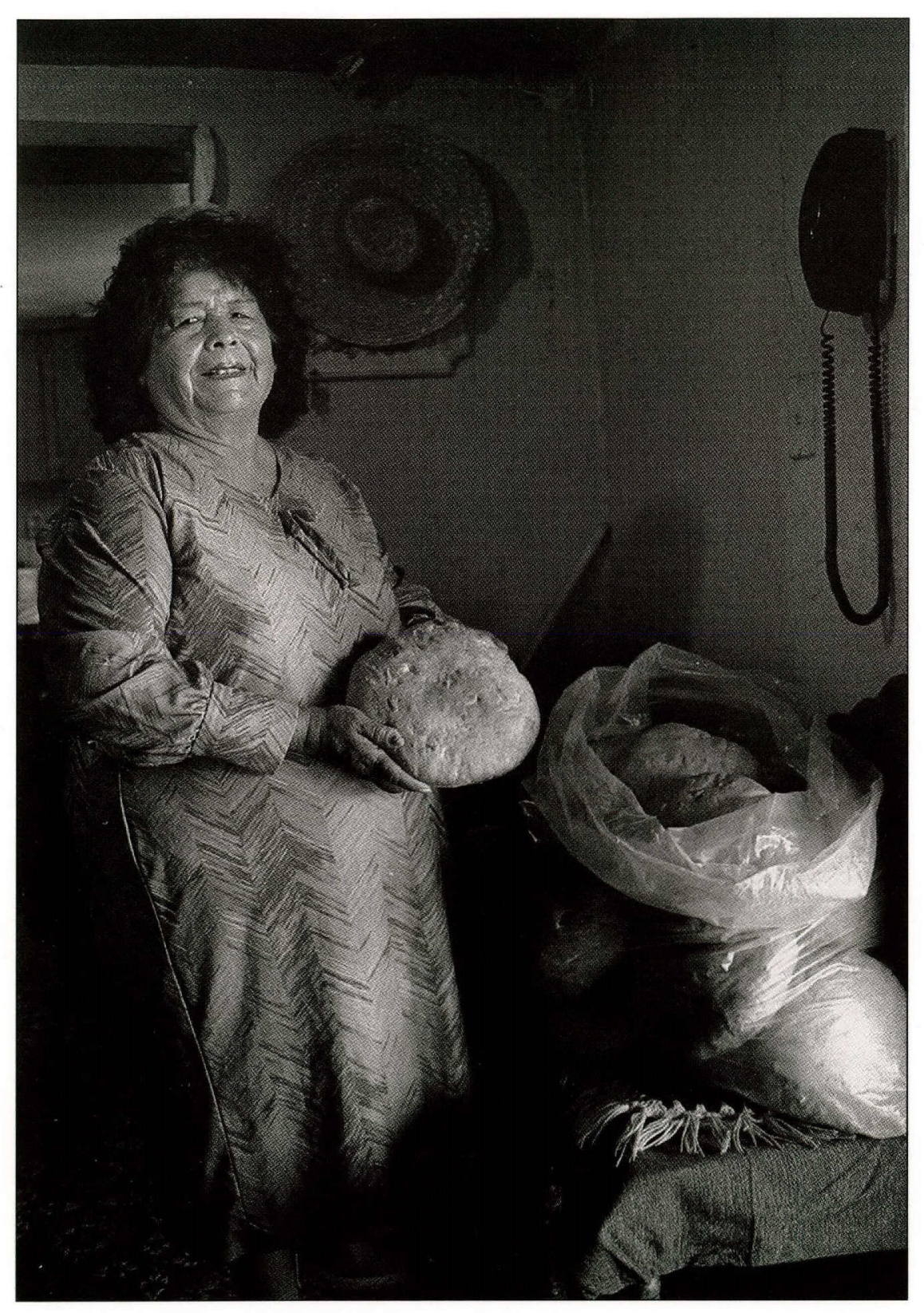


Rosie worked at the Sheriff's office of El Paso County

under the Job Training Partnership Act (JTPA) which was

started in 1984.

ROSIE GONZALES

IN SHERIFF'S OFFICE

EL PASO COUNTY 


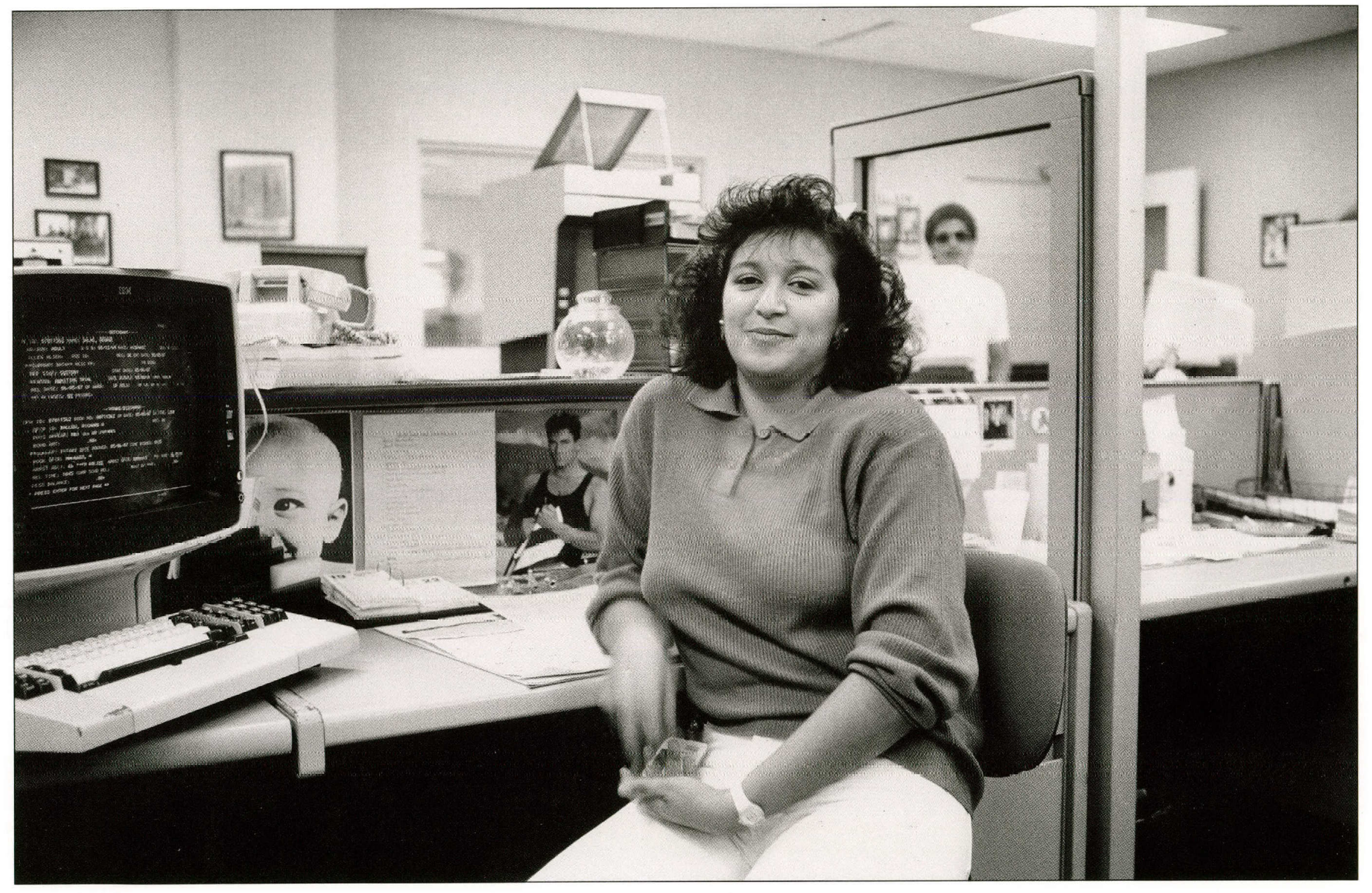


Under Title 4A, Native Americans are given on-the-job training with various goverment agencies. Juan was employed in this program, working for the Sheriff's office of El Paso County.

JUAN MALDONADO IN SHERIFF'S OFFICE EL PASO COUNTY 


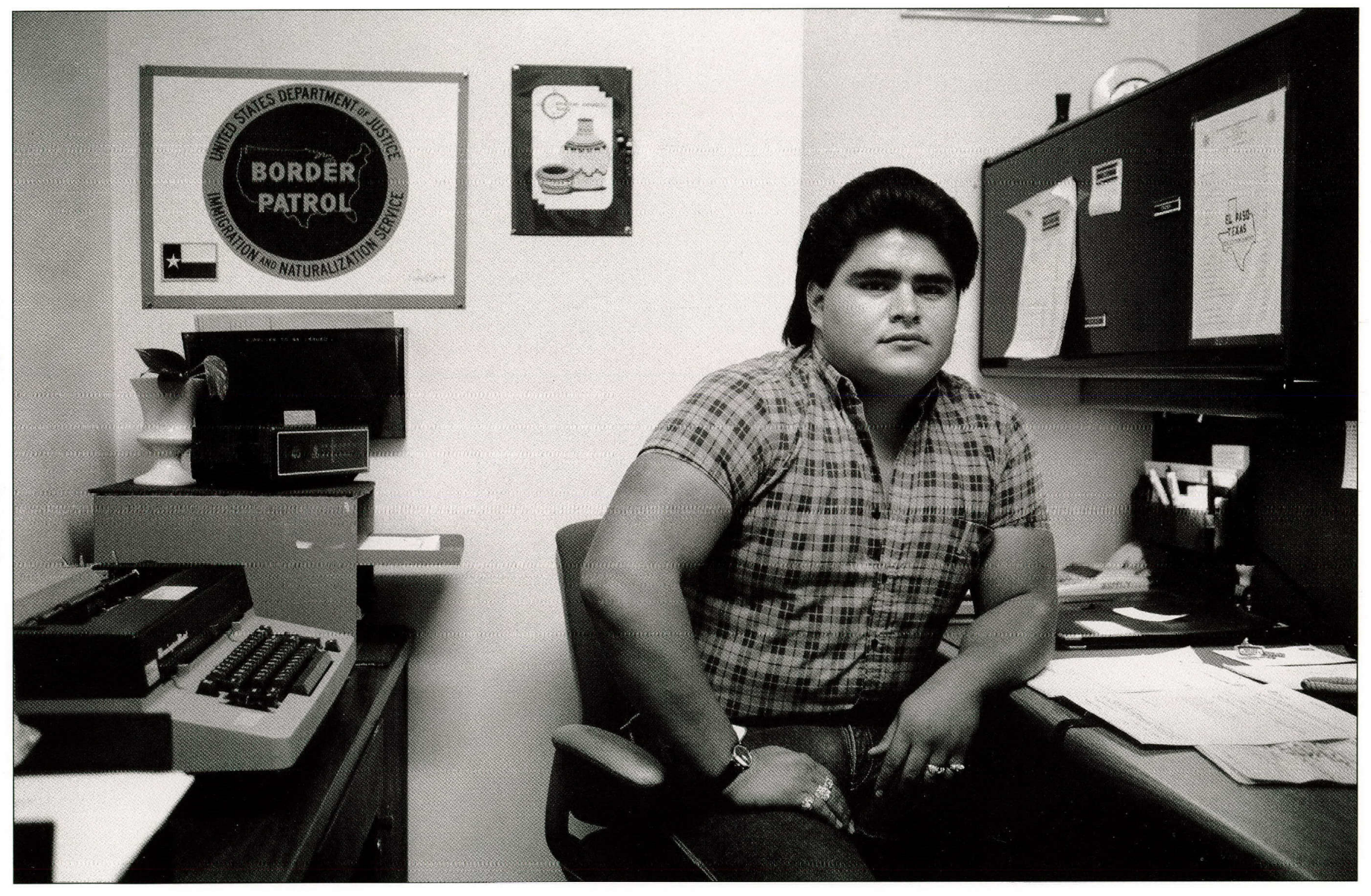


DANNY GONZALES AT

THE PASO PAK CHILI COMPANY 


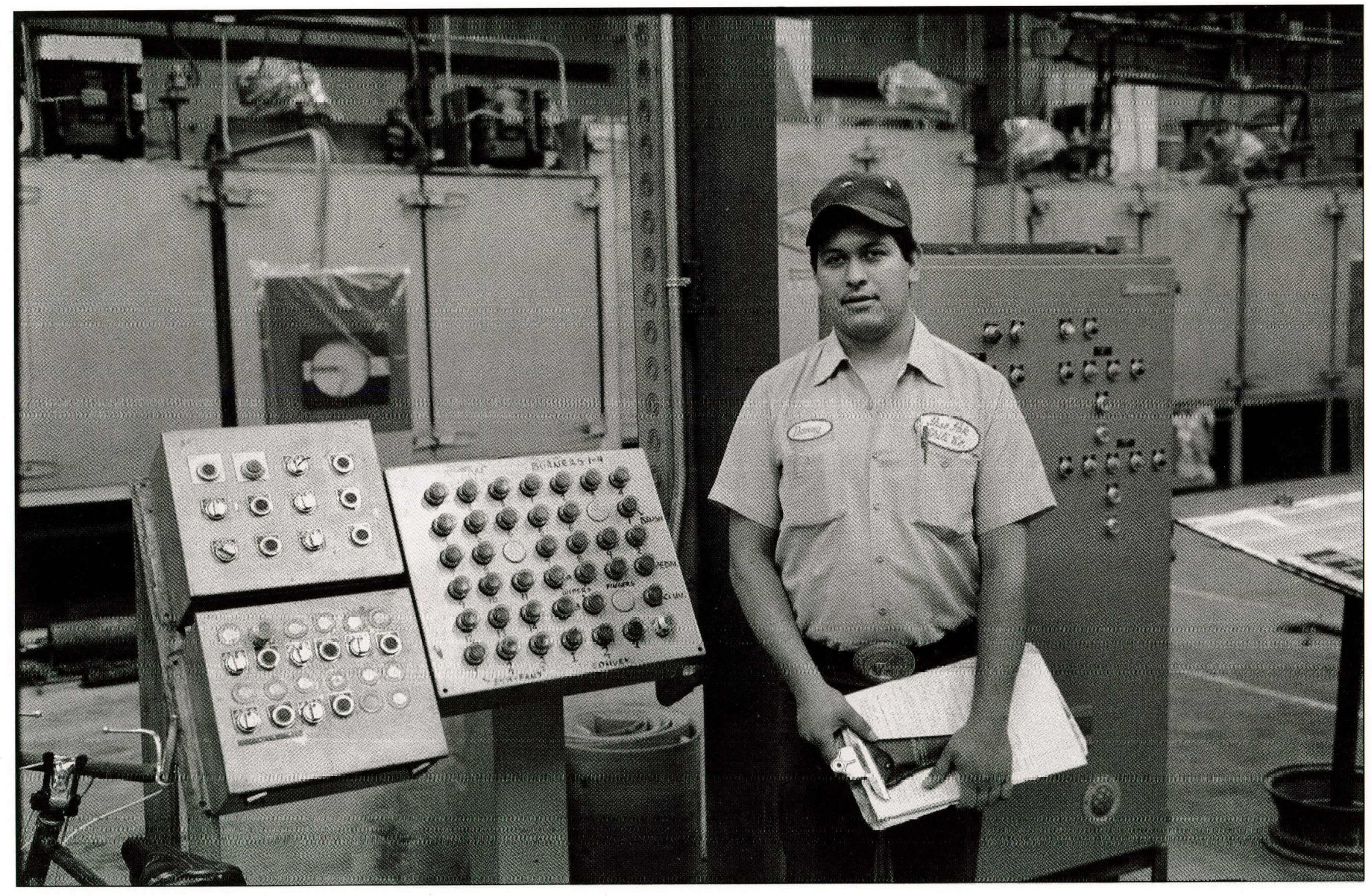




\section{CALENDAR OF TRADITIONAL OBSERVANCE DAYS (DANCES) FOR YSLETA DEL SUR PUEBLO}

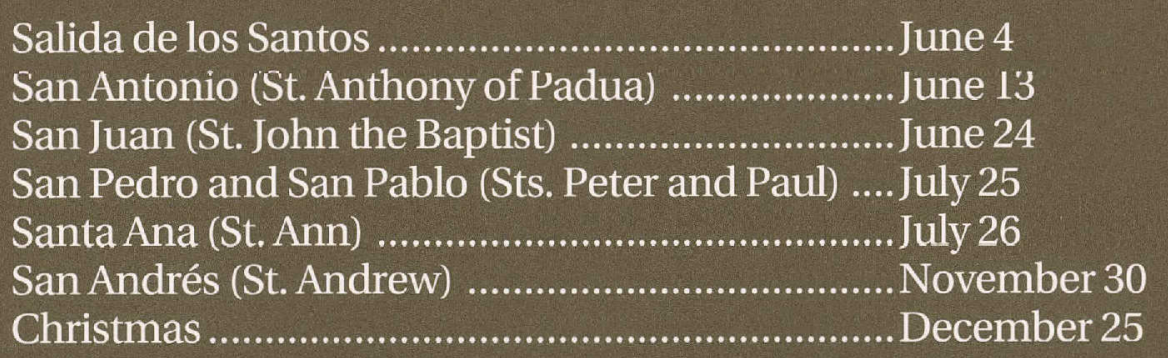

Two dances: first after Midnight Mass and

second Christmas Day afternoon

Inocentes (Holy Innocents)

January 1

Santos Reyes (Three Kings or Epiphany) January 6

\section{Ritual}


The Tiguas have a rich ceremonial life that has continued uninterrupted for hundreds of years. After the occupation by the Spanish, the native religion was integrated with Catholicism after many struggles with the Spanish, culminating in the Pueblo Revolt of 1680. After that time, the Indians were permitted to practice their historic rituals without harassment.

Much of the ritual is practiced in secret in the modern representation of the kiva, the tuhla. Non-tribal members are excluded from these observances but are permitted to observe the public performances which occur on the listed feast days. The principal feast day is 13 June, when the Tiguas celebrate their patron, St. Anthony. There is a mass, then a procession on St. Anthony's Day carrying the image of the saint to its place in the mission of Our Lady of Mt. Carmel, which was established by the Spanish after the revolt and their retreat to the El Paso area. This is followed by a ritual scourging with varas from the river, then dancing and a public feast.

Today, there is a movement by the Tiguas to rediscover those traditional practices which have been lost over time, strengthening their connection with the past as they maintain their identity in the modern world. 


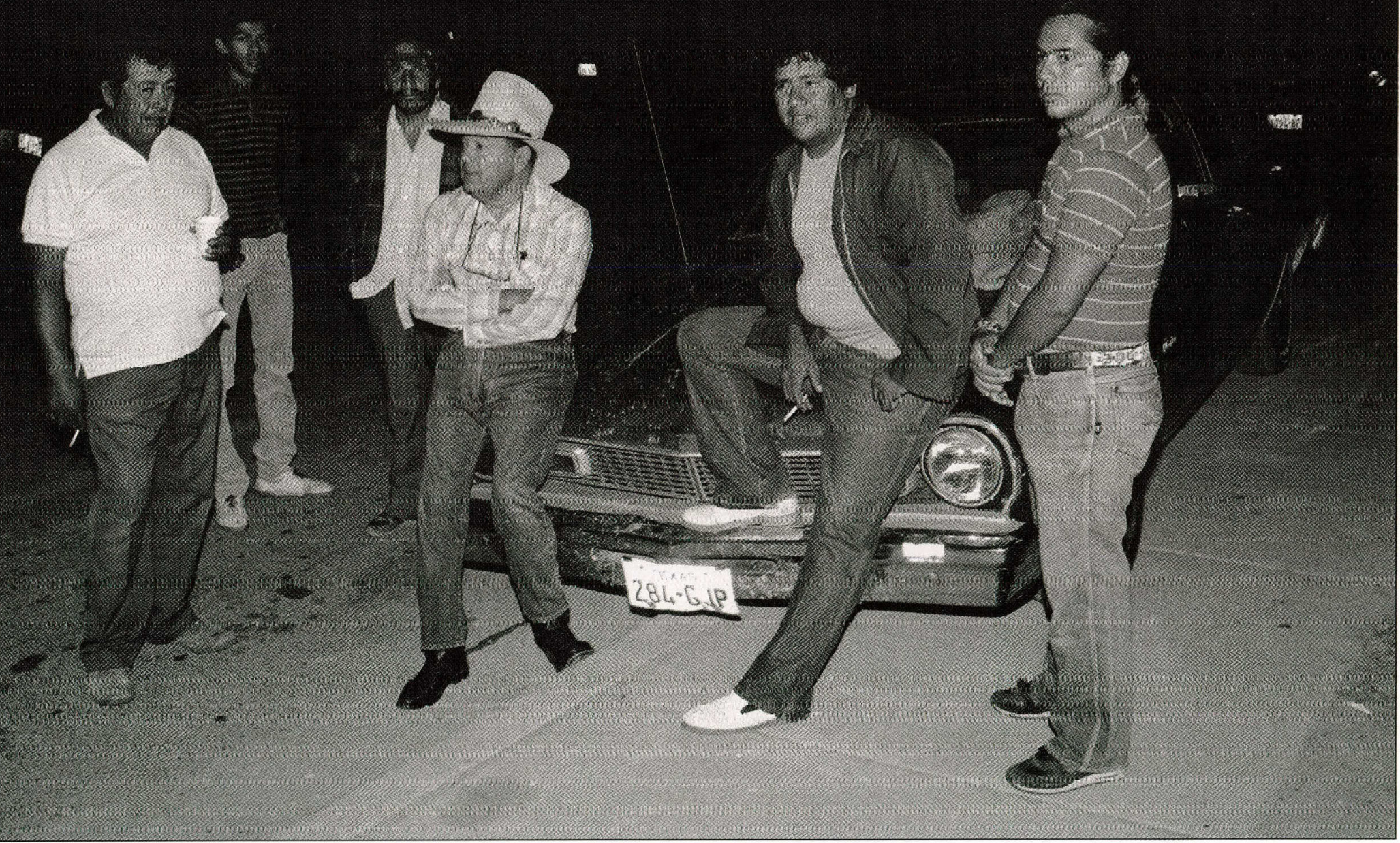


Prior to the feast day of Saint Anthony, members of the tribe gather at the home of the mayordomo to share a

breakfast and then disperse in the four cardinal directions, to secure donations for the public feast to be held in con junction with the celebration of St. Anthony.

Every year, no matter what day of the week it falls on, Sunday or Tuesday, June the fourth is part of the preparation for the feast day, the Feast of St. Anthony. Every June the fourth, members of our pueblo go off in four different directions from a street corner out in Ysleta, corner of Old County Road and Whitney Road. That was the corner from which our people always went off into the four different directions. I think in the old days, they had irrigation ditches from the four directions that would meet at that point. The people, our Indian people would get together at that corner. They still do today. They go off from that point as being the center, and they begin their June fourth donation seeking for the Feast of St. Anthony from that spot

Danny Archuleta
The former cacique, Trinidad Granillo (1909-1989), with members of the tribal council disperse to seek donations for the feast of Saint Anthony.

Trini Granillo, who was our past cacique and his war captain right behind him, Ponciano, the one with the bandana. Together, they work hand-in-hand to make sure that everything is carried out properly. Trini was a good leader. In his own way and in his own style. Very nonchalant, low key, but always got across what he needed to get done. Ponciano was a good war captain. He has a throat! Can this guy sing! He can sing. It takes a lot of commitment to be a war captain. You're the right hand man of the cacique. Your responsibility is making sure that the ceremonial activities are carried out the way they should be. By golly, you better do it. The cacique is the spiritual leader. If he is not in good heart, the community is not in good heart. This is on June fourth. They are getting ready. They are at that corner that I was talking about a little earlier, where they head out to the four directions. They are getting ready to start collecting food on that day. Seek those donations.
TRINIDAD GRANILLO AND TRIBAL COUNCIL MEMBERS 


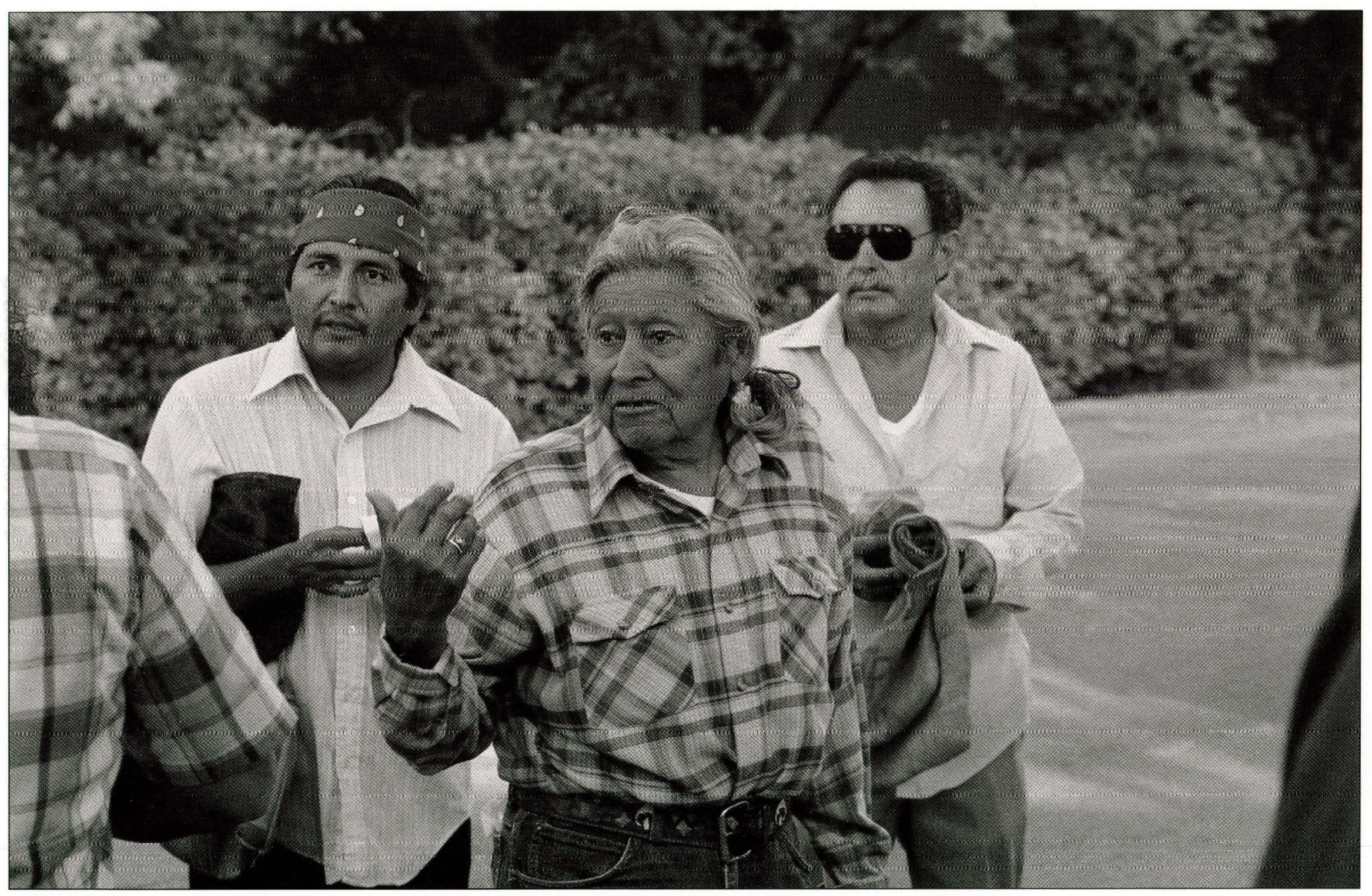


PROCESSION OF TRIBAL MEMBERS IN FORECOURT OF THE MISSION OF OUR LADY OF MT. CARMEL 


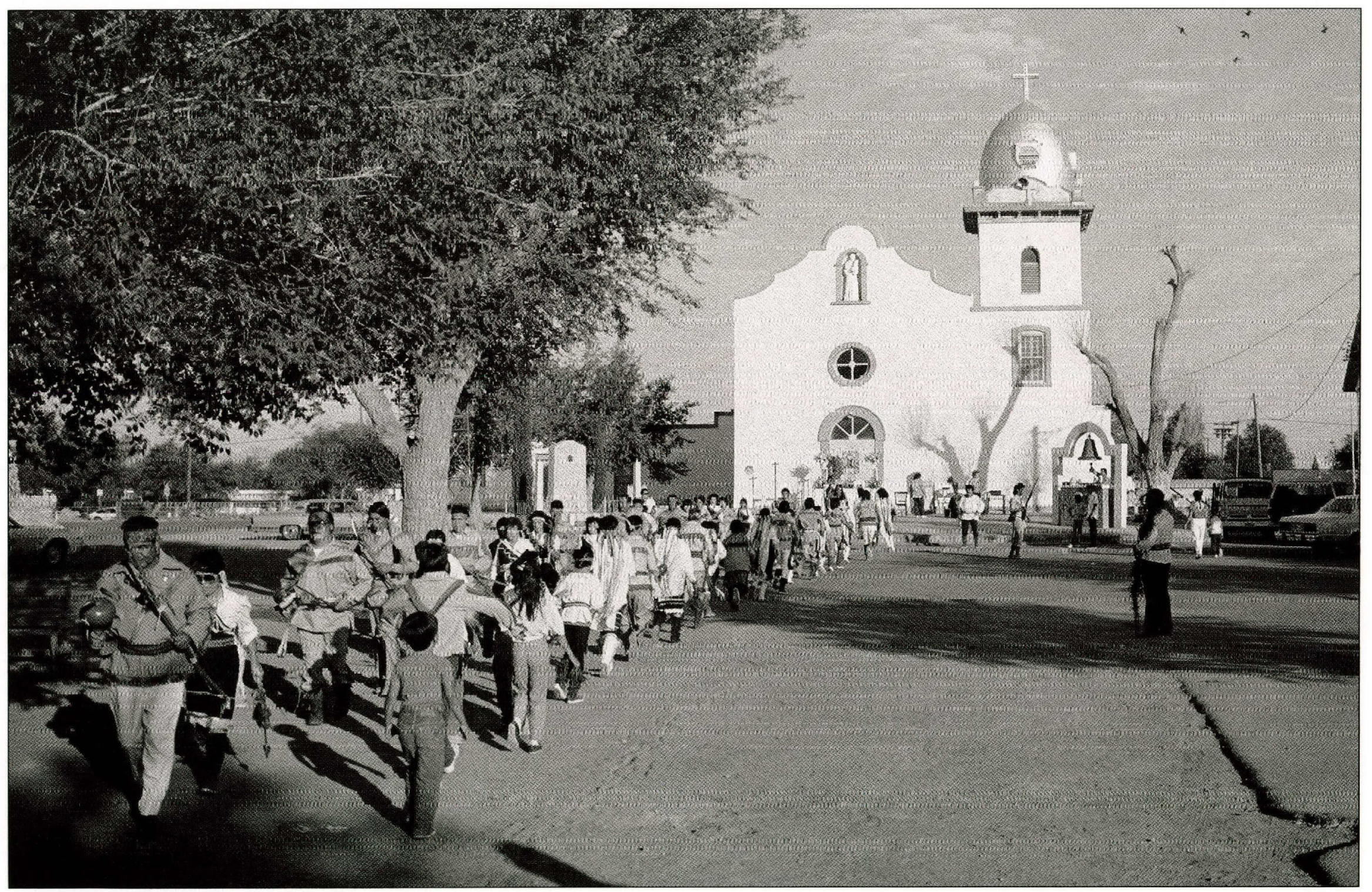


PROCESSION LEAD BY TWO PRIESTS 


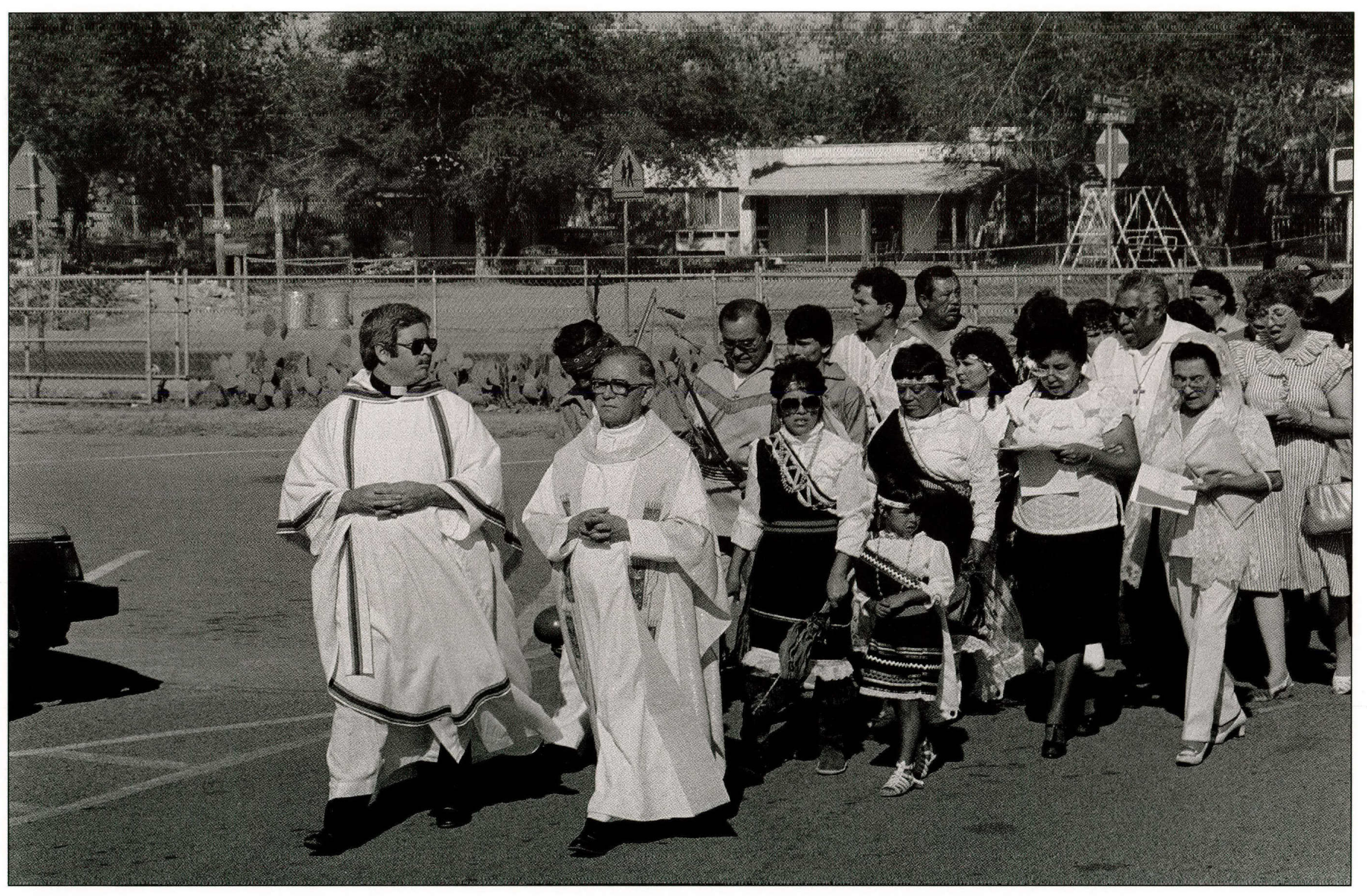


BONNIE AND VERO HOLGUIN (IN COSTUME) GETTING PHOTOGRAPH TAKEN IN FRONT OF THE MISSION OF OUR LADY OF MT. CARMEL 


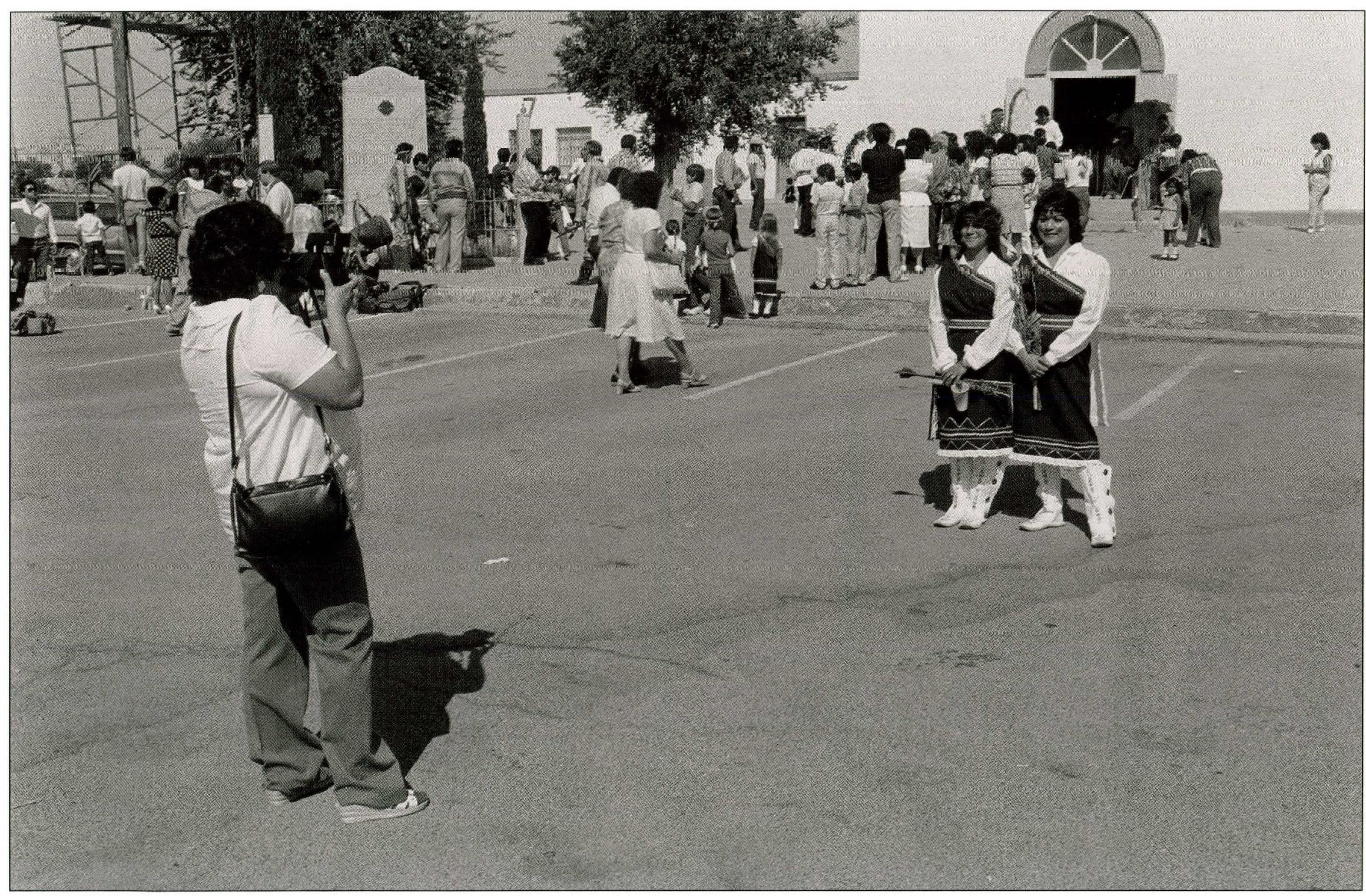


OMAR VILLANUEVA, JOSE ROBERTO LOPEZ, ZEPHORAH CANDELARLA, AND CELINA

CANDELARIA AT FEAST OF

ST. ANTHONY 


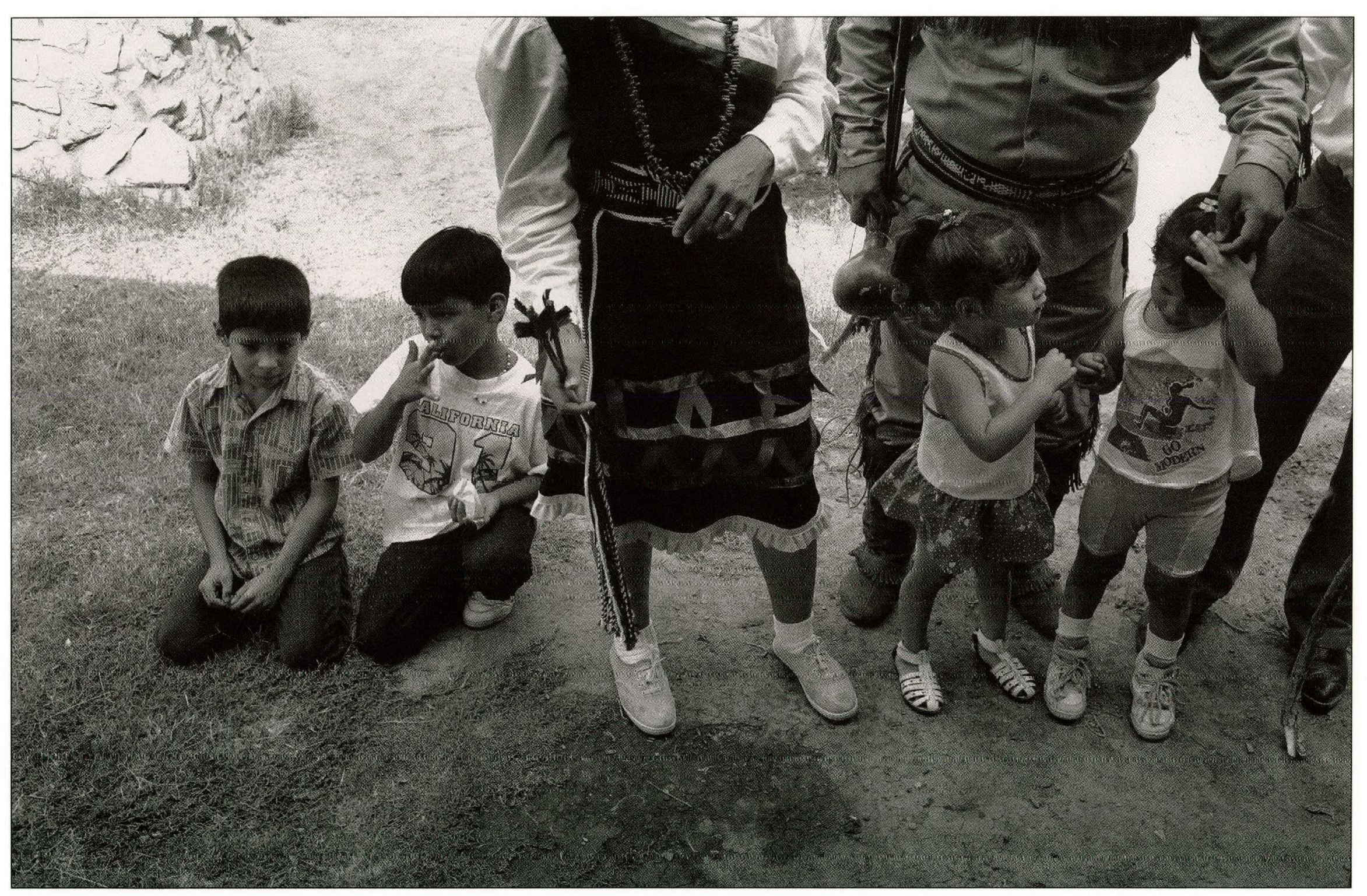


Each year the mayordomo of the tribe has the responsibility of decorating the image of the saint and preparing the public feast. It is a great honor and each family takes great pride in the decoration.

LUIS AND MARYLOU SILVAS

WITH THE IMAGE OF

ST. ANTHONY

IN THEIR LIVING ROOM 


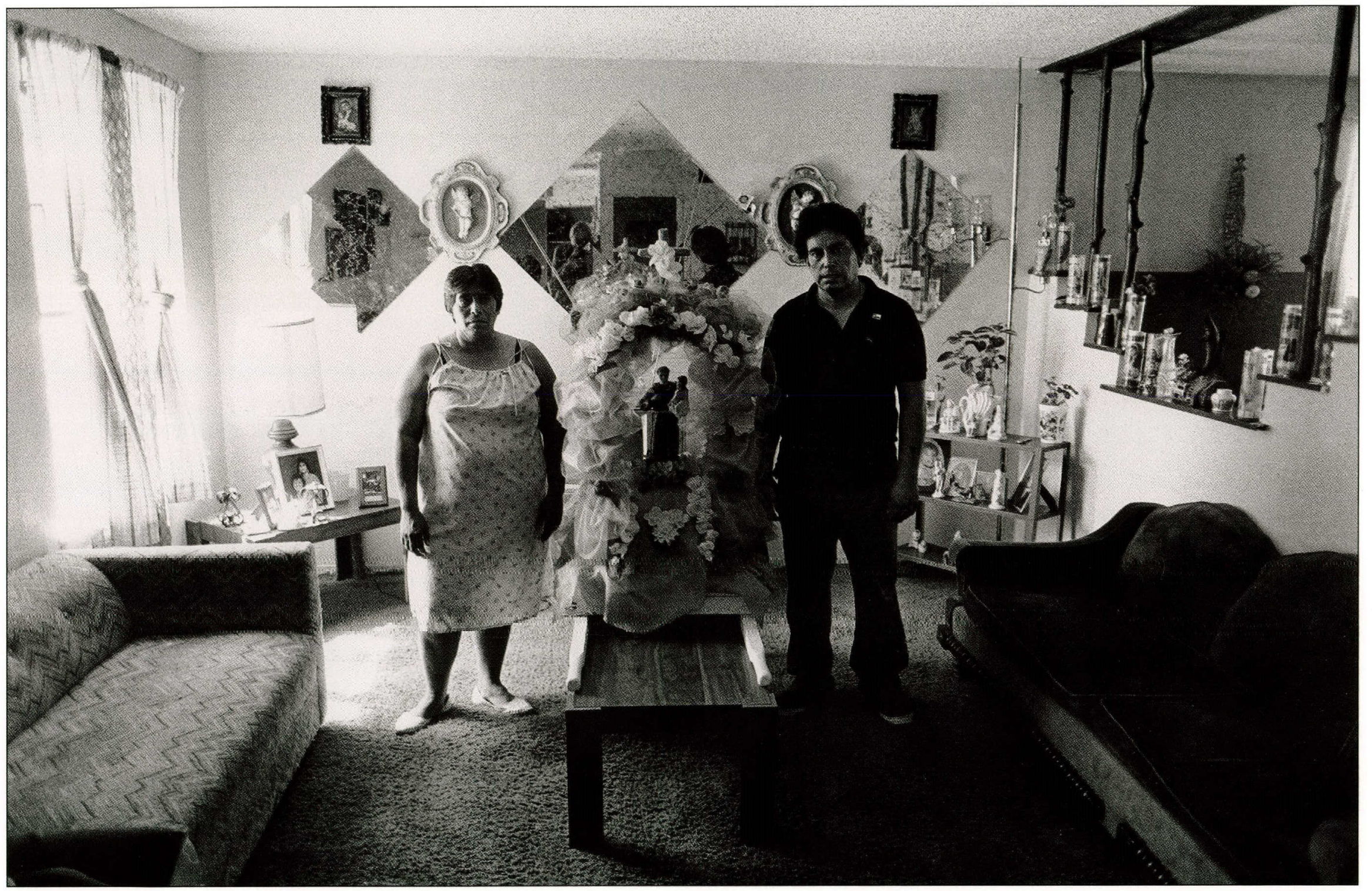


Not all members of the tribe participate in the tribal customs. Many are interested in more modern things. I think it is particularly important for the children to know the tradition. I really want to teach them. When I was young, we all used to get together in the old house and tell stories, about years back...what our grandfathers used to tell us. Now if you try and talk to a little kid, they start laughing. They want to play with their Nintendos and all that sort of stuff. Still there are some that want to learn but it's getting real hard.

Johnny Hisa

They are coming out of the community with St. Anthony coming from the house of the first mayordomo. They are going to go up one of the roads that leads to the mission. Boy! It takes so much preparation to carry out the Feast of St. Anthony. There is just so much. Here the community comes together, once again, every year. Differences are set to the side. They become one big group of folks who recognize that we are Indian people. You lose that throughout the year. You could lose who you really are because you are so caught up in trying to pay bills and get to work, putting your kids through school, the news, the war. It is just so much. Then every June, it just all comes together. We are a community; we are a group of people. We are Indian! I think ties to the Indianness are reestablished every June. 


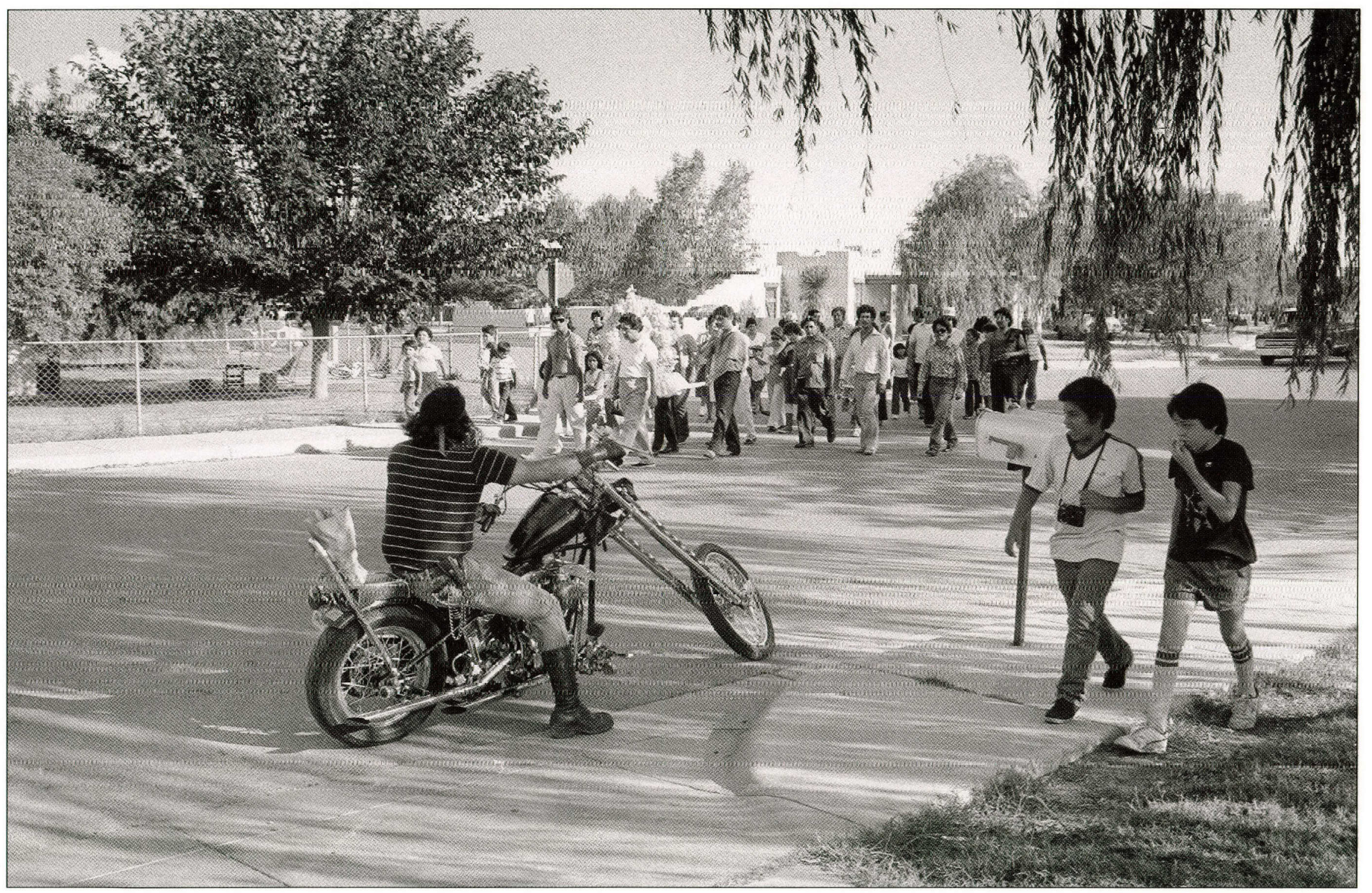


The day before the feast day, the decorated image of the saint is transported to the church where it remains until the celebration. The rifleman marches in the front of the group to call attention to the procession and to call the other Indians to join the group as they march toward the church. Traffic stops as the procession crosses major thoroughfares. Periodically the gun is fired.

Tony can really take some large steps. Tony Granillo is on Granillo street, so Shorty Gomez says, Granillo on Granillo. There goes Tony, he is ready to stop traffic and all. The gun carriers, the pistoleros, are usually chosen by the stewards for the feast day.

Danny Archuleta

The reason the pistoleros shoot their guns as they walk along is for the protection of the dancers. In other words, protection of the tribe. At one time, even in the early 1900s, there were people who did not believe in this tribe. There were people, that if we walked on the streets, they would try to run over the dancers. So the purpose of the gun was for protection. It was our law. We could do anything we want. Today, of course, we have the security guards. The tribal officer is much more beneficial to us. We don't have to worry. We carry blanks in the shotguns.
ANTONIO GRANILLO LEADS THE PROCESSION ON THE EVE OF ST. ANTHONY'S DAY

\section{Manny Silvas}




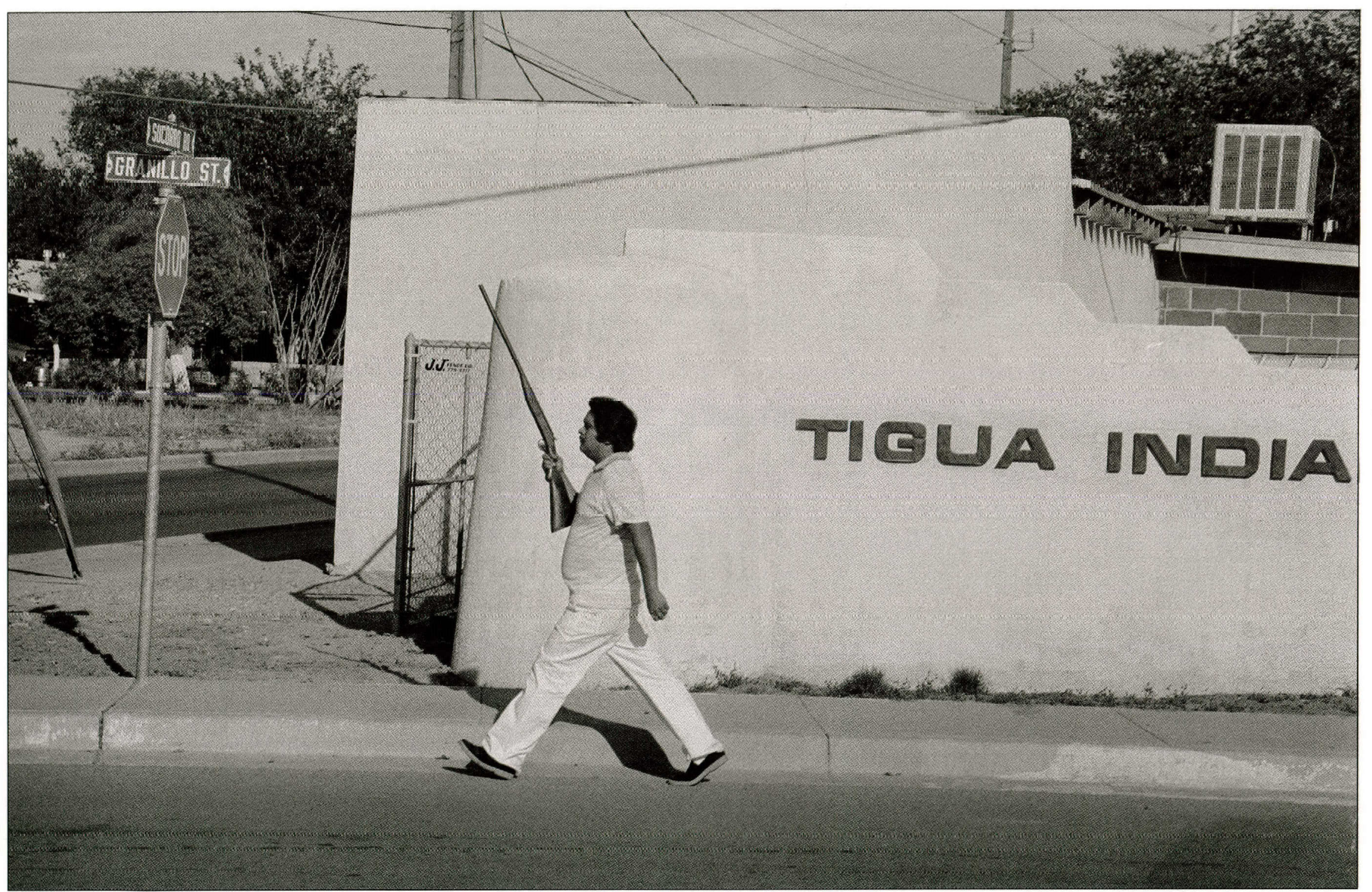


The morning of St. Anthony's Day, 13 June, a procession of tribal members proceeds from the Tuhla in the Old Pueblo to the forecourt of the mission church. A mass is conducted and the celebrants then perform their public dances. In recent years, there has been an emphasis on accuracy of the costume and practice. The dresses with the flower design have been discarded because they are representative of other pueblo peoples rather than Tigua.
On St. Anthony's Day there are many events. The dancing, the community, the feast, the mass, the tired feet at the end of the day. The gathering afterwards, where all the guys get together and talk. The boys and the women get together and talk. So much of the preparation leads to this St. Anthony's Feast Day. The commitment from the dancers... the dancing... the practices... the songs. You can almost feel this energy when you are practicing on the Saturdays. It gives you a second wind. You can hear the drum: boom! boom! boom! As you hear this drum, you can feel its vibration. It is like thunder that is very strong... very strong. You can hear it. You can hear it go boom! boom! boom! The songs. People stop to see what is going on. What are the Indians up to now? They are preparing for St. Anthony's Feast Day. The procession. It's not just a procession they are going through. It is a ceremony! It is the songs! It's the commitment of each individual.

The flower is not a Tigua symbol. You see one of the young Indian ladies here has a picture of the Sun God. The Sun God is honored as a pueblo power. Sky power. Like a kachina almost, a representation of a spirit. But they are not supposed to have these designs on their dresses.

I think we as a people are trying to hold on to our ways. We are trying to make an effort to preserve the correct way, not begin to develop takeoffs from what is traditionally a certain way of being. 


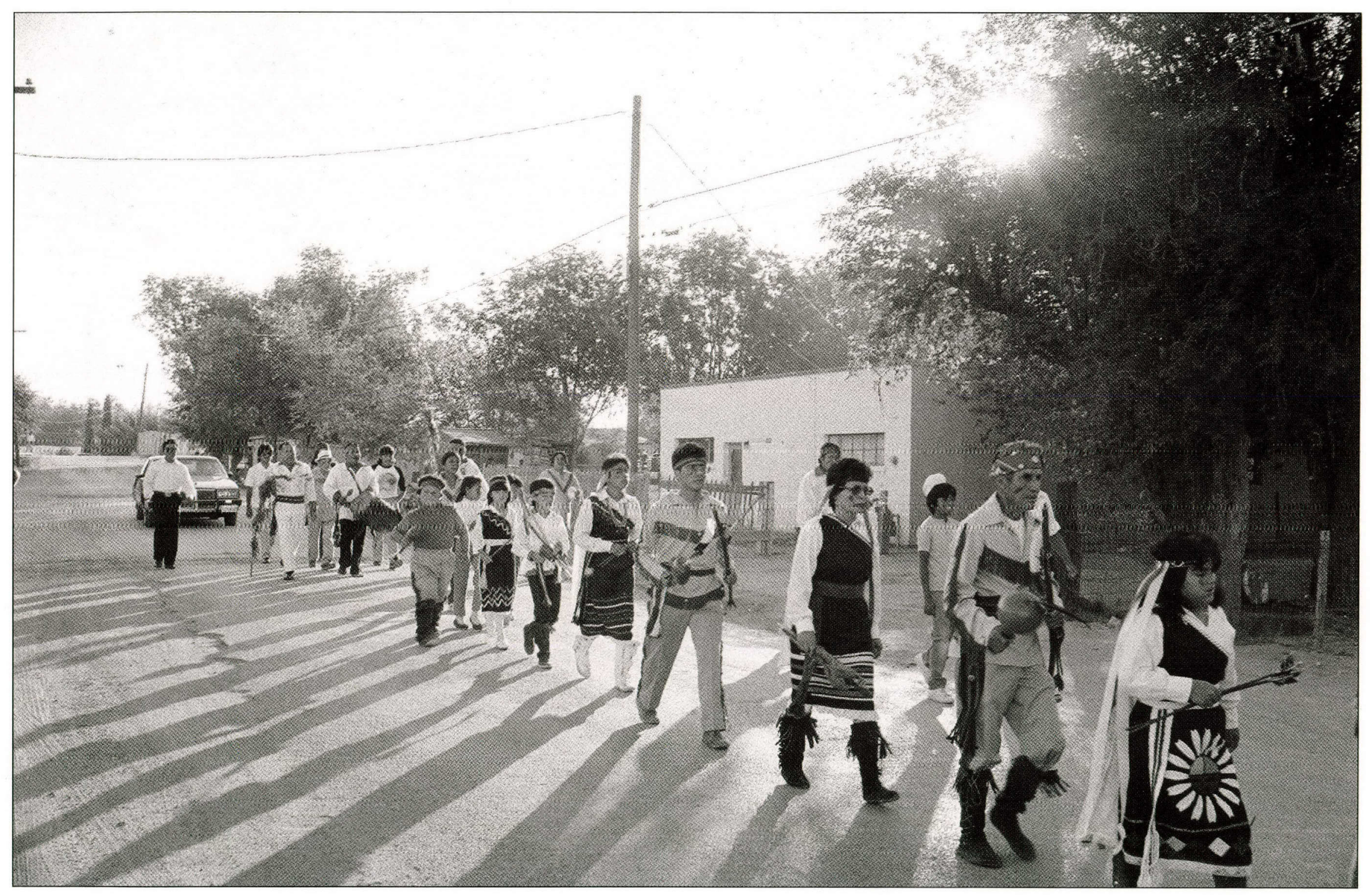


Joe Sierra, one of the older folks now, is teaching his grandson about the lifestyle, the traditional ways. What it is like to be Indian. He is molding him. The little one, he knows what the paints are all about. He is touching the paint, putting it on his grandfather. A little one, on his grandfather. Touching, rubbing it on. It is a very red, red paint. It is a powdered paint. If you get it on your tribal clothing, it doesn't come out. Usually, the women are painted with two dots, one on each cheek, right at their cheekbone. One dot at their left cheek and one dot on the right cheek. The men are painted from the bridge of their nose, between their eyes in a slanted direction, going towards their cheekbone. It looks like an upside down " $\mathrm{V}$ " that is painted onto the men. This rock comes out of the mountains around the Hueco Tanks area. It is hard to locate. They burn this rock, they heat it up and then they grind it down to create the powder. It is this powder that they use to paint the male and the female during the religious ceremonies or other special activities, even funerals. They depict tribal members, the male and female. It designates that group of people. Designation. We recognize each other with this paint on our faces. It is a reminder of what we are traditionally all about. 


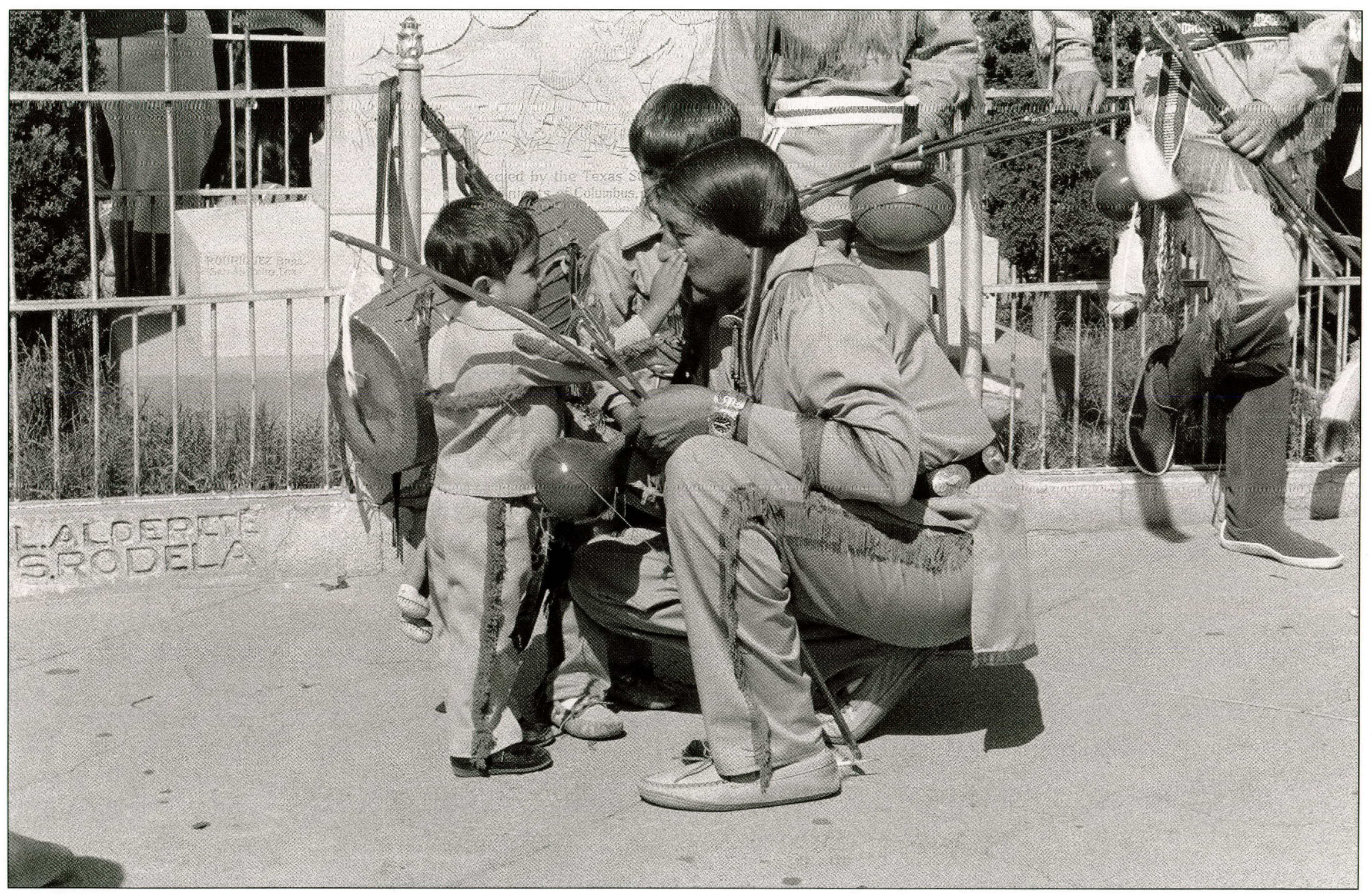


The tribal officers perform this ritual whipping on the steps of the church during the feast day of St. Anthony which occurs each year on 13 June. They are using willow

branches from the Rio Grande which had been cut at 4:00 a.m. the morning of the celebration. They are called varas.

Members of the tribe ask to be whipped in honor of St. Anthony, our patron saint. We are like the messengers from St Anthony. People make promises to him when they have some one sick, and St. Anthony will help them keep their promise. When the individual gets whipped, it's like taking their sins away from them. That's what it means when you whip them. They also take the whipping on behalf of someone else, like Christ took death on behalf of all of us.

Johnny Hisa
I remember being a member of tribal council. When I was a member for three years, I too had the responsibility of standing at the steps of the church. I had a lot of respect for the people who would come up and kneel before us, because I knew that they were kneeling there for a reason. Something was not going right for them. Through their faith, they asked for something. They asked St. Anthony to provide the message to God, to remedy whatever it was that they were facing. Difficulty... challenges... circumstances. We would take turns whipping these people in the back of their legs. I would always walk up to them and tell them, "I just hope that whatever it is that you are asking for, that it has been granted to you. That if it has not been granted to you, that it comes soon. I understand that you seek something and my prayers are with you." I would take my staff and whip them once on the left and once on the right. I would make sure that I would do it hard, not because I wanted to hurt them, but because, just like these people were committing themselves kneeling before me, I was committing my faith. I was whipping them so that God would realize that I was serious about how I wanted to help them get the help that they were seeking. Some people really go through a lot throughout the year. These staffs, these varas that are being used, are gathered from the river. They are broken off by your bare hands, no tools, no nothing. It can get difficult. If you are not careful, you can even fall into the river. But you tear these things off with your bare hands and it gets very difficult, because they are so green and fresh. They are so hard to tear.
LARRY VALLES PERFORMING THE RITUAL WHIPPING OF PENITENT, MARY JOJOLA 


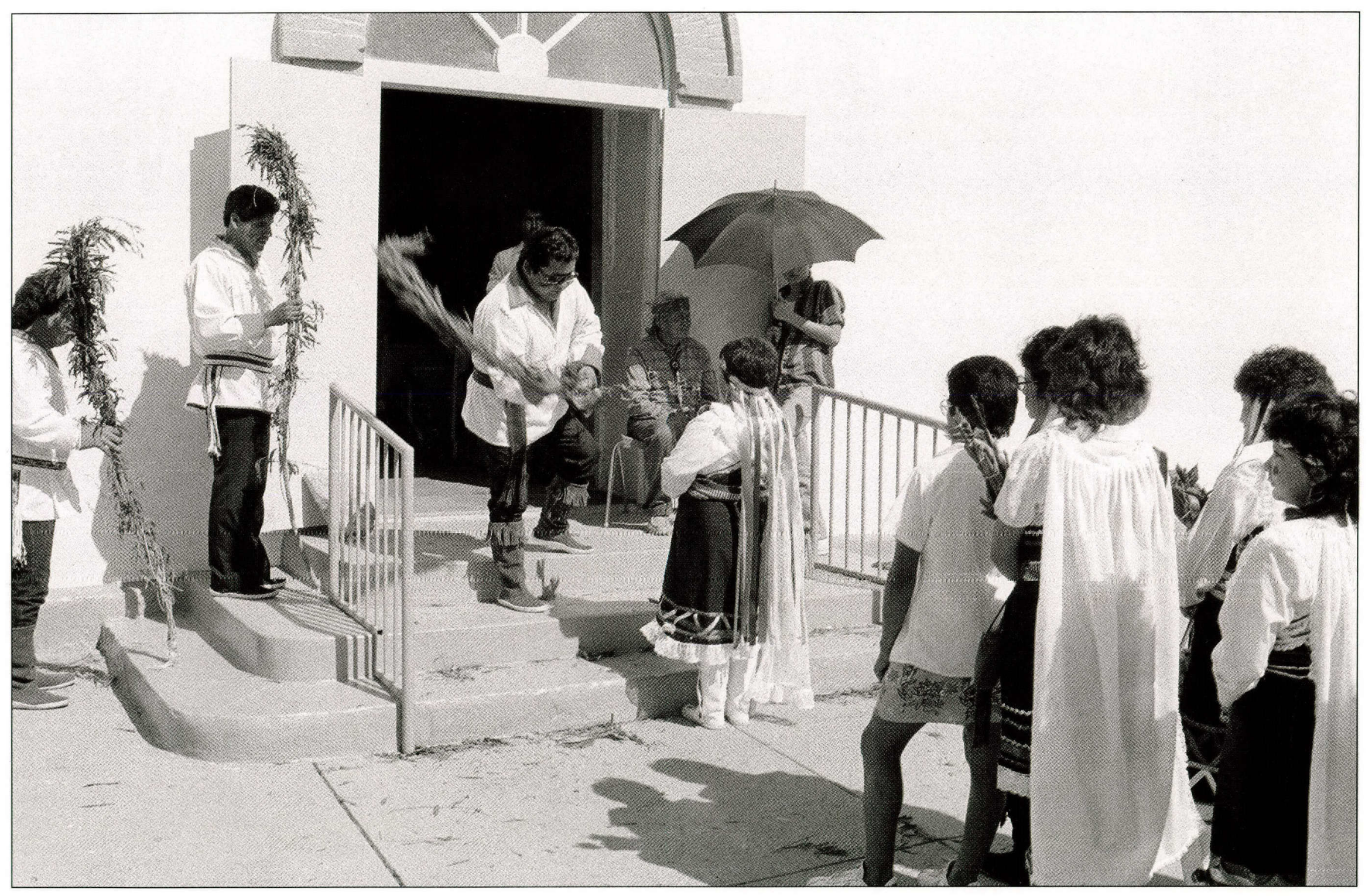


The dances performed for the public are different than the dances performed in the secret rituals observed by the tribe. These public dances are a way of expressing public appreciation for the corn, the air and water, and the other traditional elements of survival. Both women and men dance. The costumes are made by the dancers and represent the traditional clothing worn by the Tigua. The designs are copied from early photographs and clothing handed down by family members.

It takes a lot of strength to dance all day.

St. John's Day. You know, I still remember this day. I remember this day very well. I had a lot on my mind this day. It is a good thing that I was dancing next to my best friend. Because, me and him when we dance, we dance in synch with each other. It kind of kept me in perspective of what we were actually doing and what things were all about. All of the guys, I think all of us give a real sincere effort to dance properly, and honor, not adore! Honor the saints that we dance for. We honor the saints. We adore Jesus. We pay tribute to our Indian ways. 


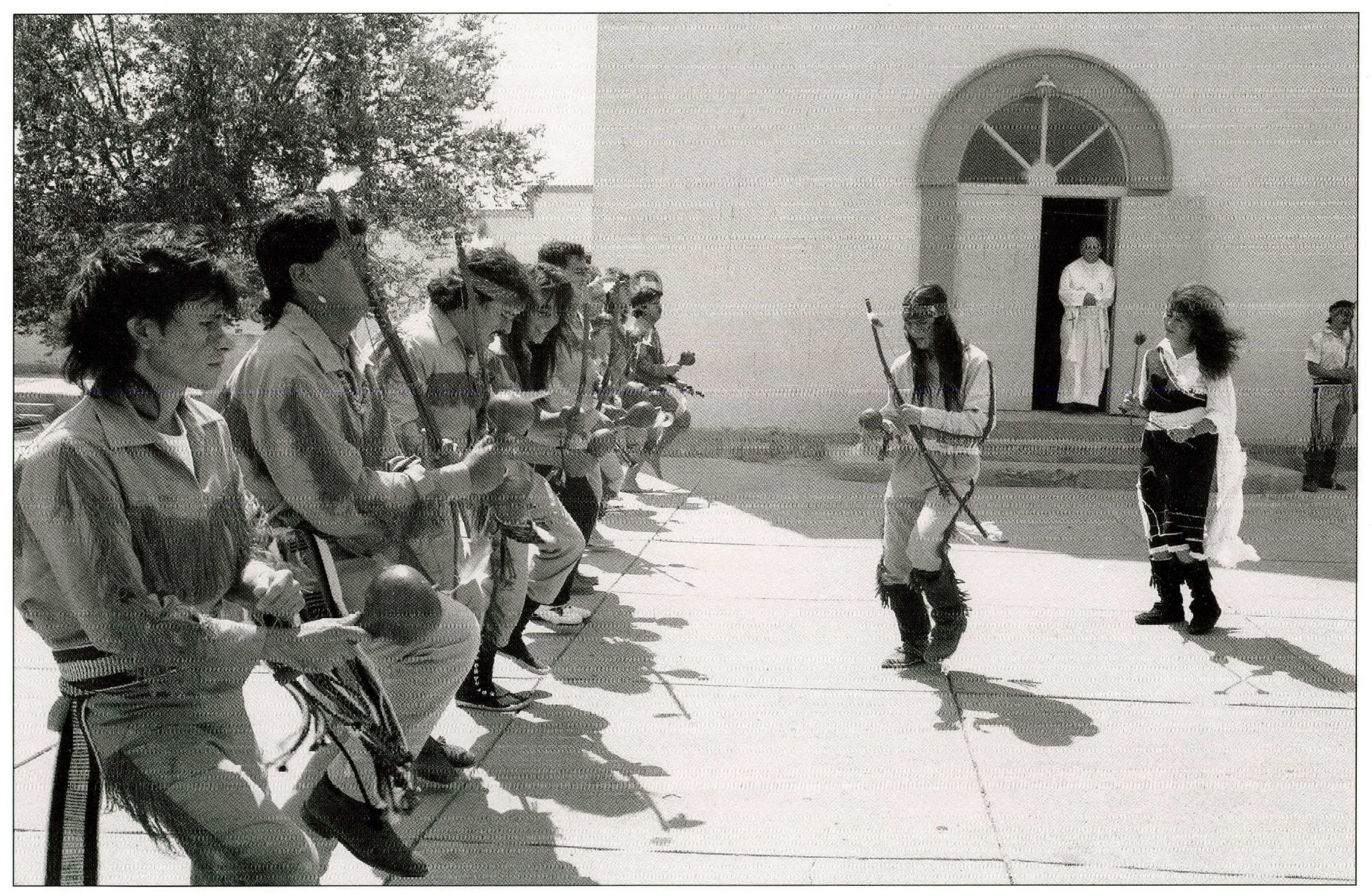


Cory and Rosamaria are skilled dancers and participate in the ceremonial dances on feast days. They made their own costumes and the jewelry was made by Pueblo Indians, in the traditional design of the Pueblos.

SYLVIA CORINA (CORY) APODACA AND ROSAMARIA SILVAS IN DANCE COSTUME

In the late 1500 s, they mainly used the jewelry for ceremonial purposes, for gifts, even for trading. In the 1500s they traded with other pueblos, for food or any thing that they had. It is hard to believe today, because we do the jewelry with ethylene tanks and oxygen and all that. It was a question for me. How could they do this so beautifully at that time? I found out that they did not need a torch. They did it with coal. They already knew what coal was. So they used it. They had the actual pure silver. It was pure silver; it wasn't chemicalized. They flattened the whole piece of silver and made it into a plate, and from that actual plate, they took any design that they wanted. They stamped it with various different kinds of stamp, sharp objects that they had. That is the way they did their silver.

Manny Silvas 


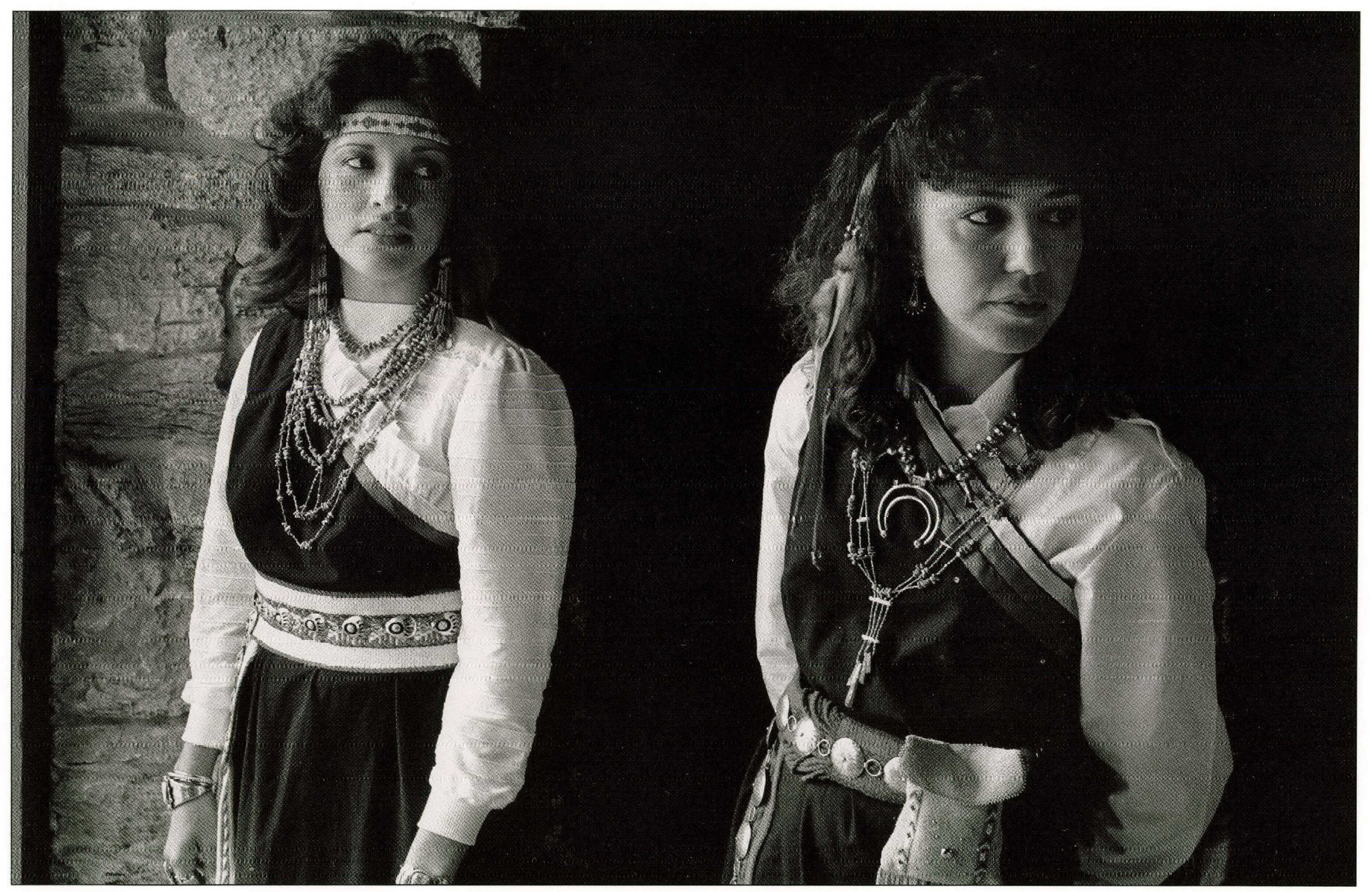


Young Tigua boys and girls begin to learn the dances at an early age. The costumes are modern representations of the old clothing.

Ronnie started very young. He had the opportunity to start young and I think he appreciates who he is, and he is very proud of who he is. He is Indian. He is a young little Indian boy. In the future he will be a young Indian man.

Danny Archuleta 


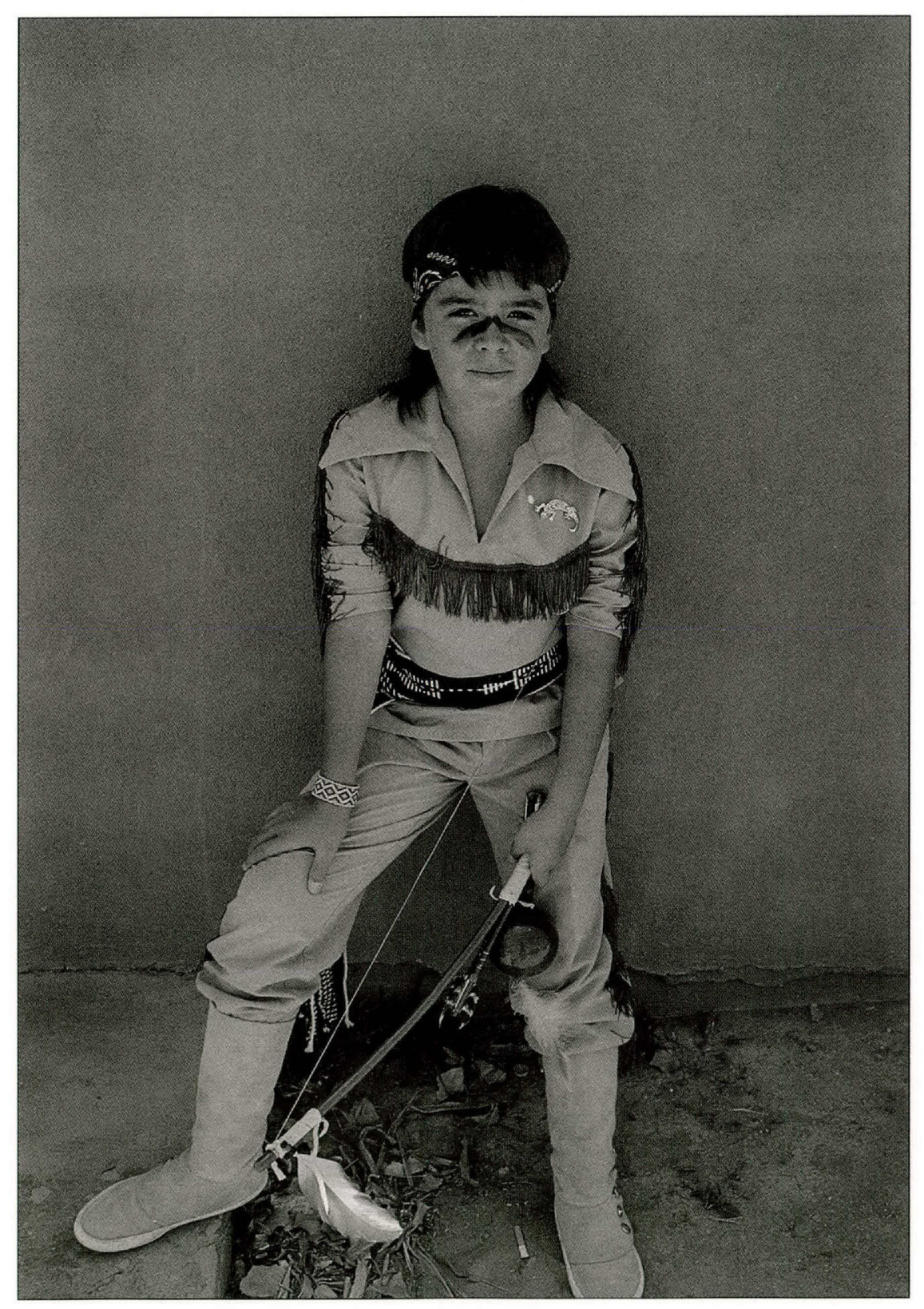


On St. Anthony's Day, 13 June, the tribal members perform the public dances in the forecourt of the mission of Our Lady of Mount Carmel. He is holding varas cut at the river (Rio Grande) to use in the ceremonies.

Our mission, our cacique and spiritual leader, Trinidad Granillo; Trinidad and Mary as dancers, these are all elements that have come together, and depict a lifestyle of our people. The dancing, the songs, the church, Catholicism. The traditional clothing. The leadership, the responsibility, the patience. This is what makes up our people, here at Ysleta del Sur pueblo.
FORMER CACIQUE TRINIDAD GRANILLO AND MARY JOJOLA

Danny Archuleta 


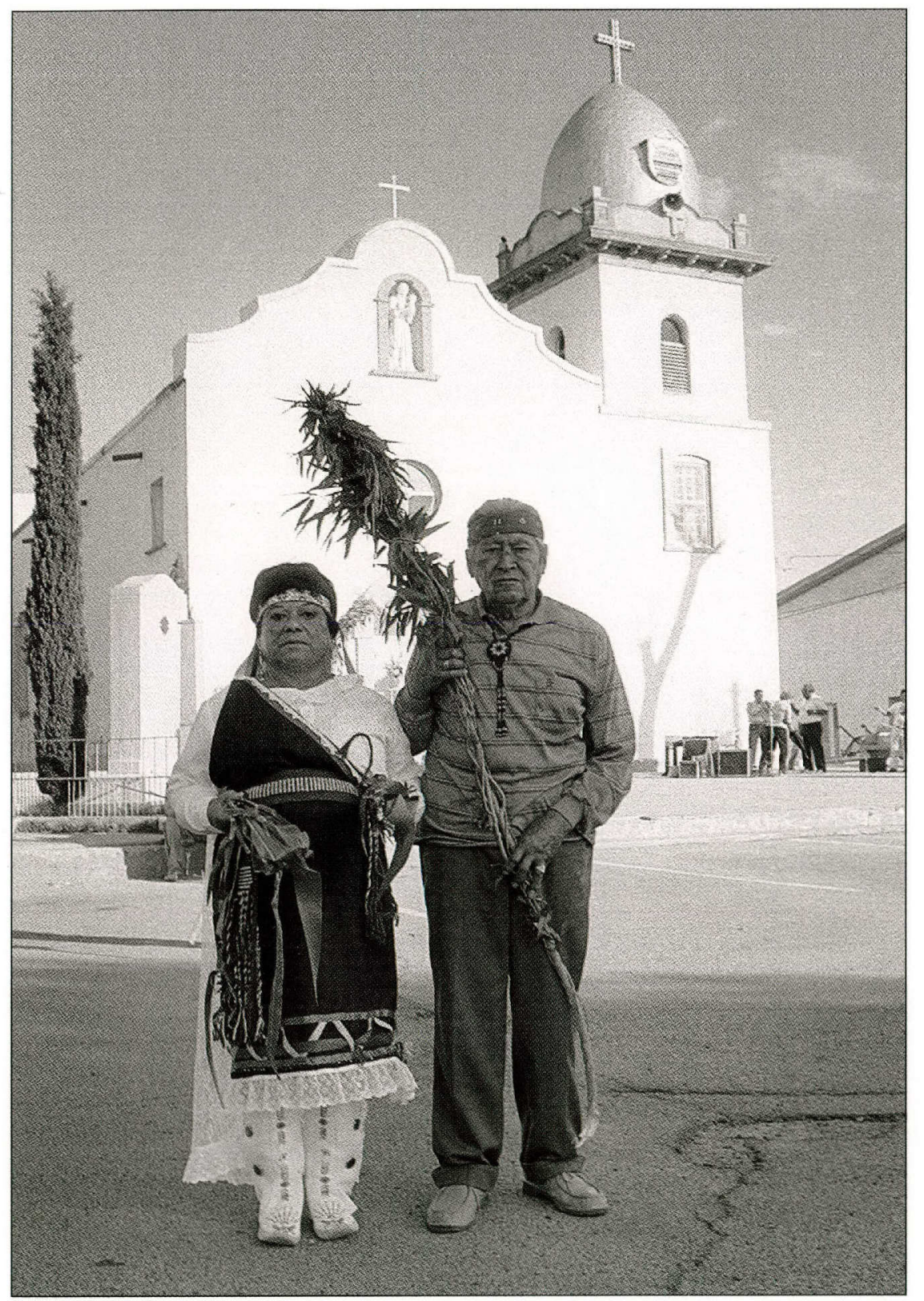


Cacique Enrique Paiz shows the gourds used by the Tigua to make the rattles or guajes, used in the dances. The gourd is cut in the neck, and small pebbles are introduced. A stick to be used as a handle is inserted in the neck and secured with leather thongs and glue. The guajes have religious significance for the tribe.

The rattle or guaje is used in all of the dances. They represent the rain. The rain. I have a whole lot of respect for the rain because it nourishes the ground. Just like words nourish the mind. Too much of something could be bad. Just like too much water could ruin crops, too many words retained in the mind could ruin the point of view that one has for other things.

Danny Archuleta 


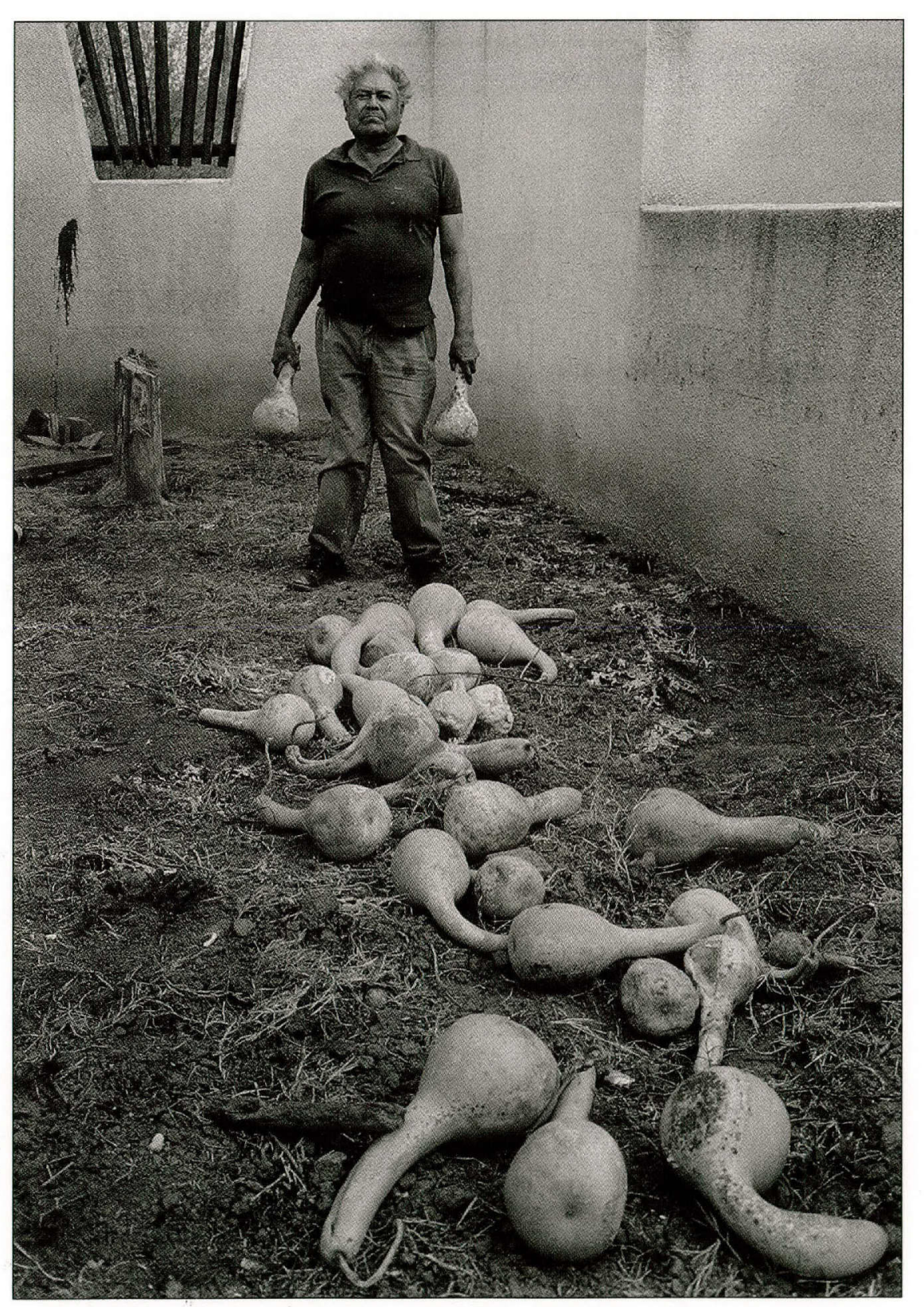





\section{Interview with Tribal Leaders}

JULIAN GRANILLO, GOVERNOR, MANUEL SILVAS, LIEUTENANT GOVERNOR, AND MIGUEL PEDRAZA, FORMER GOVERNOR,

YSLETA DELSUR PUEBLO, 20 JANUARY 1993

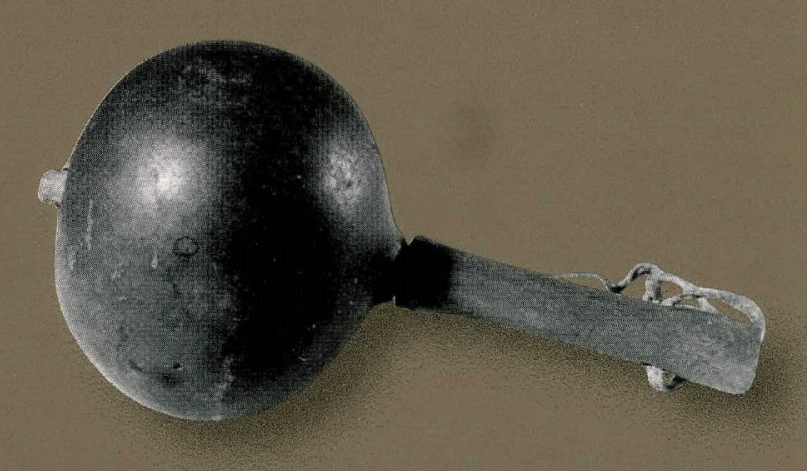



Wright: Congratulations, Julian, on your election as governor of the Tigua tribe at Ysleta. It is a fine honor and carries a great responsibility to your people. What are your plans and hopes for the coming year?

Granillo: Our plans are to get everything in order, starting with the administration. We have had problems getting the social services we were entitled to, available to our people.

Silvas: In the past, our people have not received all the services they were entitled to. Our goal is to provide these services and focus on uniting our people. Then, regardless of the problems of the past, we will be going on to other ventures. We are going to look into new things that will be good for the tribe.

Wright: Why have you not received the social services? Have they not been applied for?

Silvas: No, the application was done. The money was here. It was channeled to other programs instead of using it for services to the people. So Julian's goal right now is to redirect those funds to better serve the people instead of going to those other programs.

Wright: Let's talk about the new ventures the tribe might undertake. I understand that you have signed a contract with a company that will supervise gambling operations for the tribe.

Granillo: We hope gaming will enable us to provide more services to the Tigua people, services that some of our people cannot receive through BIA right now because of the blood quantum requirement. With these gaming monies, we can provide services to the entire Tigua family, not only those who have a blood quantum of one-eighth or more.
Silvas: We consider our tribe as a whole. We don't want to excommunicate a person if they happen to be non-tribal.

This is a family, and we have to try and help that family as a whole.

Wright: In the past, have the federal services been available only for those that have minimum blood quantum? Granillo: Only for those that have one-eighth pure blood. We could have a situation where the father and children could qualify but the wife could not because she was Hispanic, not Indian. Children beneath the one-eighth quantum don't receive any federal services. This is what we are trying to change by creating more income sources for the tribe.

Pedraza: The new council would like to form a financial umbrella for the whole tribe to service not only Indian people, but non-Indians that are living among us. . to give provisions to the family as a whole. The council would like to cover everyone that is within the community: non-Indian spouses, or children who don't qualify for federal support. We are going to be able to service all those people with money that will come in from gaming, instead of coming from the federal government. The federal government will not provide these services, nor the money to do it. But gaming will.

Wright: In other words, by the tribal council's decision, you can eliminate the blood quantum as a requirement for tribal membership, and provide for those tribal members the same services as the government now provides for those who have a blood quantum of one-eighth pure blood or better. 
Granillo: Gaming will not only provide funds for social services, it will provide jobs for our tribe and the entire El Paso area.

Silvas: Everybody is going to benefit from this. You are talking about three thousand employees. The tribe cannot provide so many employees, because we are not that much. Just like Julian was saying, the city of El Paso is going to be affected. Everybody is going to get a piece of it.

Wright: Would you discuss the dissension that has been in the tribe this year? I know that your election promises to bring the tribe together, but what were the factors that divided you this last year?

Silvas: When this council came into office, we felt we needed to make changes, administrative changes, in order to move the tribe ahead and do all that needs to be done. Right? But earlier councils wanted to also destroy members of the tribe, just because they were in power or just because they felt like they didn't vote for them, or they felt something. O.K.? Now Julian came to this office with a different approach than others. I would say the unity of the tribe is more important to him and to the council than their jobs.

We are not firing anybody, we are just telling them this is the way it is going to be. There is not going to be any more abusive behavior from anybody.

Granillo:: We don't want people to be threatened or to feel threatened by this council. We are trying to unite everybody. We have no intention of taking anybody's job. There are needs out there, and as they come before the council, if we can meet those needs, we are going to help those people. We are not going to use social services money for utilities or whatever. That is the purpose of the tribal council account. So we are going to use it for that purpose. We are trying to help the people. We are here for them, not for our own personal thing. The pie is so big everybody can have a little small piece of it. We intend to distribute our resources to everybody in the tribe, regardless of their blood quantum or their participation in the work of the tribe, or their religion. There is a lot of people who do not participate in our religion and ceremonial dances. Regardless of that, they will still get the same.

Pedraza: For example, before Christmas the gaming committee gave the tribal council $\$ 125,000$. For the first time in history, the tribal council divided some of that money and gave each member a gift certificate. This is a small example of what we are trying to do. In the past, all who have benefited from what we have, have been employees or whatever. The people in the back have never gotten anything, and we want to distribute everything.

Wright: Let me ask another question about the gaming. Do you see that it threatens any tribal traditions?

Granillo: It is either we become rich, or we stay poor. One of the two.

Wright: The tradition remains?

Granillo: Nothing is going to change. Tradition is in our hearts, it is here. That is what has kept us a tribe. Most people might think I look like a Mexican or whatever, but deep inside I have always been a full-blooded Indian, even though I am not full-blooded. It comes from the heart; it comes from the tradition, from living with the elders. Long ago, there were not so many Indian families; now we have a 
lot that have enrolled because of the tribe's recognition. But talking for myself, for Manny and for Mike; we feel we are talking from the heart. Since we were in school, we were discriminated against by other kids, by our teachers, by the community. Now everybody wants to be Indian.

Silvas: Let me add something to that. I remember when I was young, we used to have a dirt floor. I remember when we lived in the barrio. They used to chop trees for the wood stove. Outside my house we had a water pump. We lived in several different homes. I tell my kids, at that time we didn't have this or that. I don't blame my dad or I don't say "Dad we could have had more." At least we had a roof. We had a table that had food all of the time. Even if it was beans or tortillas, it was there. It was there three times a day, with no problem. Yes, we were poor... second-hand clothes. That is life.

Granillo: We shared what we had. If we needed food, other Indian families used to come to us. We all shared what we had.

Wright: Do you believe that a sense of community is going to be destroyed when everyone gets involved in the gaming venture and a lot of money is going to be spread around?

Silvas: The tradition will continue. Today, what we have is totally different from those early days, but our customs are more beautiful. Why? Because we have a little bit more. We are talking about three separate families right here that have stuck with tradition, and we have come up from nothing to where we are right now. We are not saying that we have much, but at least we have something, and we can probably say that we have been part of all of this.

Wright: You have all seen a lot of progress. Today your homes are quite a big change from the old barrio. Moving to the government housing was a big step.

Silvas: Yes, but even the BIA is holding us back. They expect us to progress the way the other pueblos do. The other pueblos are going very slow. We are ahead. We make demands, and they don't like that, you know.

Pedraza: One of our big advantages over the other pueblos is that we have always been surrounded by white people. We learned to take the criticism of the white people and live through all of that. We fight back and still keep our own customs.

A few years back, my father was building an addition to his home. He must have been reported or the city found out about it, and the city came over and told him that he could not build unless he got a permit, a city permit. My dad turns around and says "No, this is Indian property. I have lived here all my life, and I consider this as my home, so I don't need a permit." They said well, we are going to stop you. We are going to fine you. Then my dad really got upset about it. He says, "O.k., do you see those telephone poles over there? There are four of them, and that is my property. What I am going to do is get my ax from my house and I am going to chop them down, because they are on my property." Right away, he got on the telephone and called Tom Diamond, and Tom Diamond came over and saw the problem and advised the city that Dad was ready to chop those telephone poles down. That was the end of it.

Wright: Speaking of tradition, I know that at the time that 
the Tiguas were recognized as a tribe here, that there was some opposition from Isleta, New Mexico. How is the present relationship with Isleta, New Mexico?

Silvas: Everything has been O.K. with Isleta. I have a relative who lives there. She is full-blooded Tigua. She lives on the old reservation. People you meet there are friendly the way we are friendly with them. We go to their houses and they will ask us to stay overnight. "Let's have some supper!" If they come down here, we do the same. We are the same family. Two or three years ago, there was a lady governor of Isleta. I don't know how they got her in there. The tribal council made a bad decision in letting women hold that office....

They regret it now. They regret having the constitutional bylaws, because they are tied down to the United States government. We are not.

Granillo: There are only two Pueblo tribes left that are traditional. Ourselves and Santo Domingo. What Manny is saying, is that it is all tribal politics. It depends on who you have in office, and if they want to work with other tribes.

Wright: Let's talk a bit about the recent visit of Columbus relative. I remember that the Tigua officials refused to meet with him when he came to El Paso. What was your reason for snubbing him?

Silvas: He was supposed to be the great-great-greatgrandson, or whatever, of Columbus. He wanted all the tribes to accept him, so it was a big thing nation-wide, for all tribes. Columbus did nothing but destroy America. We spoke with the governors of the northern pueblos and they were all against it. We had to be unified with our other pueblos.

Wright: I know that you have been discriminated against in the past. How do you feel the El Paso community is accepting the tribe today?

Granillo: They should understand that we are accepting them, not them accepting us. That is how I see it. We have been having some problems. We had some meetings with the people that are doing the bingo in town, the non-profit organizations and the Bingo Association of El Paso. They were saying that they were upset with the tribe because we were going to break them.

Silvas: They were only thinking of themselves. But who has considered how we have lived, how we have felt for so many years? Nobody has said what about the Tigua Indians, who is going to help them?

What about the land? Who owns this land, or who used to own this land? Who took it away? They don't see that, they only see themselves. They don't care about the tribe.

Wright: This is just a small group in El Paso, the people that are running the bingo. What about the other people in the city?

Silvas: The majority of the people are with the tribe. This land is tribal land. We are a sovereign tribe, but we are still in compliance with the city. We don't need to tell them of our plans but we still go and say that we are going to do this and that. We want to work together. Ninety-nine percent of the El Paso community is supportive of this tribe and also this tribe to them.

Pedraza: As a courtesy, the tribe met with the Bingo Association and advised them what we were going to do, just 
as a courtesy. We told them we would contribute to all of the charities that they contribute to. There was opposition on their side, and we told them that whether they liked it or not, we were still going to have a casino.

Granillo: What we are trying to do is bring in something that is going to be of general benefit for the city of El Paso, not just for little groups. It is in general, because if we start bringing in people to El Paso's hotels and motels, there is going to be better business. Everything is going to benefit. That is what we are trying to do, not just a venture for the tribe. We are including the whole city of El Paso.

Wright: You know, you mentioned the role of women in the tribe. Presently there is a movement among the women of the tribe to have a greater role in tribal government.

Granillo: The only one I can speak for is myself. I don't know about Manny or Mike. This is the way I feel. You have your traditionalist and you have your non-traditionalist. You are talking about Indian people. The men have traditionally been the leaders. Do you know what I mean? I strongly believe they should continue to be the leaders. I'm not saying that it might not change, but as long as I am here and I am alive, I guess I am going to support what has been tradition. The men are the leaders.

Pedraza: You also have your traditional women who believe the same thing.

They support the tradition.

Silvas: We grew up with tradition. Others who just came in the late seventies, or eighties, who lived all their life in California, were living with women's liberation and so. They want to come here and take over.
Granillo: We don't want to go down as being chauvinist. Silvas: We don't want to keep women out because we don't want them. Women play an important role within our tribe. We are talking here about the council. We are not talking about a group for the Bingo Committee, housing or whatever. Women will have their share of voice in that. As far as the tribal council and so on, it has been men and we plan to stay that way.

Wright: One of the things that I know all of you are very concerned with is the drug problem and the problems of alcoholism and diabetes, the problem of unemployment.

Silvas: We don't have a problem. We have pinpointed the solution which is to try and get those people help.

Granillo: Like Manny had mentioned, as far as unemployment, we don't really have an unemployment problem.

There are a few people not working and we really don't know whether they want to work or not.

Wright: You feel that problem has been solved; there is not a lot of drug use?

Silvas: We have control.

Pedraza: I was going to mention that, yes we did have some problems, but not more than the rest of the communities. We had our share of problems, just like the others, but not any more. It may be less because we are in a group and we know where the problems are.

Granillo: That's the reason we have an elected council ... to try and meet the needs of the people.

Wright: What about education? There was a time when the young people would just quit after high school and drop out. 
Granillo: When we began programs like the JTPA [Job Training Partnership Act] program, a lot of people including myself, went and got a GED, then went on to community college. Now we are trying to work with our kids. We know for a fact that a kid will start planning to drop out when he is about the sixth to eighth grade. They start having a problem. So that is where we try and get into those problems. The ones that need help spend the last two years planning how they are going to drop out when they get to high school, or when they get to that age of eighteen. Our tribal education coordinator will be looking into kids who are having problems in attendance or whatever.

Pedraza: Giving the children and the young adults a direction when they are young, gives them a better opportunity to decide what field they should take. If you let a child go through high school, and they still don't have an idea of what they want to be or want to become, it is going to be hard for them to make that decision. So we are starting at a very early age, making programs and talking to them as they go to high school, giving them suggestions as to what kind of career they are going to take as they move into the outside society.

Wright: Is there a lot of pressure for the young people to stay here?

Granillo: Well I think that the world is open for them. Of course, we would like to see as many of our people as possible stay within the community. But, at the same time, we don't want them to have a closed mind.

Pedraza: Right. In the future we have planned to have total assistance for our tribal members. We will have dentists, optometrists, and so on. There will be opportunities for our people.

Wright: You are not trying to pressure them to stay. They have the opportunity to go anywhere, but you want to create opportunities for them within the pueblo so they can remain within the local area.

Silvas: What we are trying to do is help them to have a better look at the world to see if they want to make something out of themselves. If they do, they have to have school. That is one thing they have to realize. They need an education. That is what we are trying to do, get our people educated. If they decide they want to stay and work for the people, that is great for us, and good for them too. But what we don't want is to have a drop out. If he decides to leave the tribe and go make a living, it is going to be great for him, because then he can be a tribal member that is making it by himself. With tribal help or by himself, we want people to make it.

Wright: Going back to an earlier question, we were talking about the Indian religion and some people are not practicing the Indian religion. How strong is the Tigua native religion today?

Pedraza: It is probably based on the individual person that confronts himself with tradition. If you are a traditional person, the way we were talking, yes it is very strong, something we carry out. Now there are some people, just like any other community or group of people, that don't want to learn. We cannot force them to become the religious people that we are. But take Manny, his whole family, Julian, myself, there is no way out. We do believe in it. We try to 
teach it to our younger tribal members, and we hope that through our knowledge they will continue and follow it and teach it to other members.

Granillo: I want Mike to comment on this. We are not really practicing our real religion, because of what happened to us. You want to tell us more about this Mike? About how the Spaniards came up and introduced Christianity?

Pedraza: Well I was telling Julian that one of the reasons for the pueblo revolt was the Spanish attempt to enforce Christianity. Yes, we went into the practice of Christianity, but in our own way. We fooled the Spanish when we accepted Christianity by having our own way of practicing in front of the churches. They thought we were practicing their religion, and at the same time we were having our own religion going on without them knowing it. We did it because they wouldn't let us do it openly, so we found our own way of doing it. They were happy and we were happy at the same time.

Granillo: If the Spanish caught any tribal member practicing the old religion or the traditional religion, they used to cut off one finger or an ear or some other part of their body to make the Indian understand: you do not practice that kind of religion, you practice ours!

Wright: But today, aren't most Tiguas practicing Catholics?

Granillo: We practice, yeah. This is one of the things I believe. Regardless if you practice Catholic, Christian, Protestant, whatever, we have the same God. You know they used to call him, whatever name they gave him, it was the same one. We call our God in Spanish abuelo, which is really the grandfather. Which is the same name as God. We believe in him.

We pray in church; we also pray in our sacred mountain. Wright: Out at the Hueco Tanks?

Granillo: Yes, we also pray in our house, we pray here, we pray everywhere, and we pray to the same one.

Wright: But you still maintain your shrines at Hueco and at the other sacred places?

Granillo: I mean, I could be driving in a car and just see a mountain, I could just stop and go to the top of the mountain or stay all night, I can clean myself, I can do what ever I want to do. I can pray there. He is all over the place. He is even here.

Wright: Why are mountains special places for worship? Granillo: Didn't Jesus and Moses and so on go up to the mountains to pray, to receive word from God?

Pedraza: Nobody taught us that, it just came natural. I don't know where it came from.

Wright: You were doing that before the Spanish came? Pedraza: Oh yes, way before then. Even the people up north, they have their own sacred mountain. Especially Sandia, who speak the Tigua language. They have their own mountain. They have their own traditional ceremony, where everybody goes and prays in the mountain.

Wright: Someone was telling me that you all still went to the Guadalupe Mountains to gather salt, is that right?

Silvas: Not any more. They used to. I remember my grandpa went and I used to go with him. That was sometime in the eighties up to eighty-four.

Wright: Do you still do the traditional rabbit hunt? 
Granillo: We don't do it as a performance on a special day, the way it was done. We do it on our own. There are a lot of tribal members that go hunting without guns. No guns, just a shovel, that is all they use.

Pedraza: A shovel or a rabbit stick. I have done it. I picked it up from my Dad, at a very early age, when my father was working for the State I Iighway Department, over on Clark Street. He was the first one that I saw hunt. He said you hunt rabbit with a stick and this is the way it is done. He showed me, because at that time it was during the war. We had a victory garden in the back in the sand hills, and I used to go with him out there on Saturdays and we used the rabbit stick. As a matter of fact, I still carry a rabbit stick in my pickup. I don't have it in here or I would show it to you. You would throw it at the rabbit, sideways, and you would hit the rabbit. But that is where I picked it up.

Wright: The big question is, what do you see for the future of the tribe?

Silvas: This is my opinion: you couldn't imagine what I see for this tribe. I see things for the tribe. I see programs for the tribe. I see benefits. I see per capita distribution. I see land. I see houses. I see a lot of things. I know it is going to be rich for this tribe, for every member of this tribe.

Granillo: I will say it in a very few words: With God's help, we hope to be a prosperous tribe, and a united tribe.

Pedraza: I believe that in the very near future, and I am not just making this up, this is going to be the richest tribe in the United States. Not being greedy, but I believe that we can provide education, better health for our children and the elders. That is one of the things that I have been looking forward to providing for our people. That is just about all in the package. With God's help. 


\section{Tribal Officers of Ysleta del Sur, 1680-1993}




\section{Tigua Tribal Officers of Ysleta Del Sur 1680-1993}

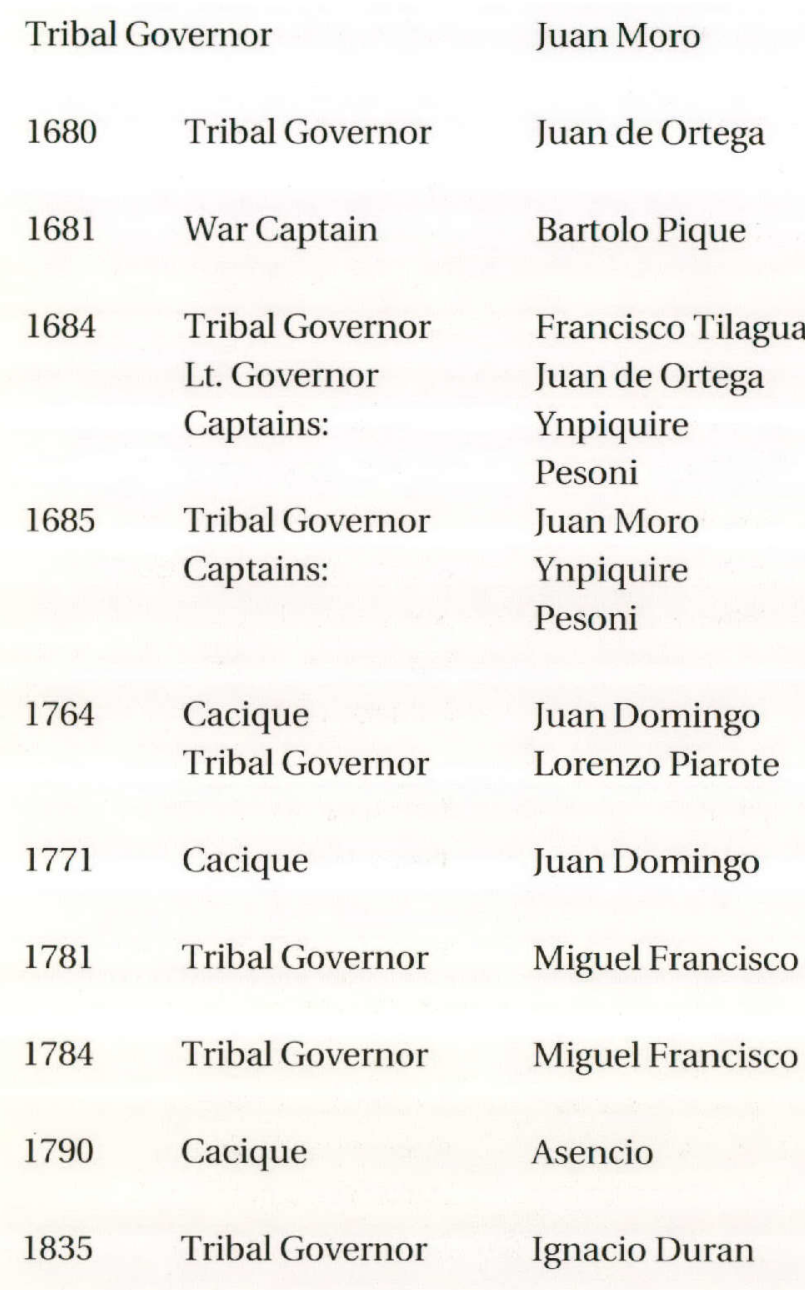

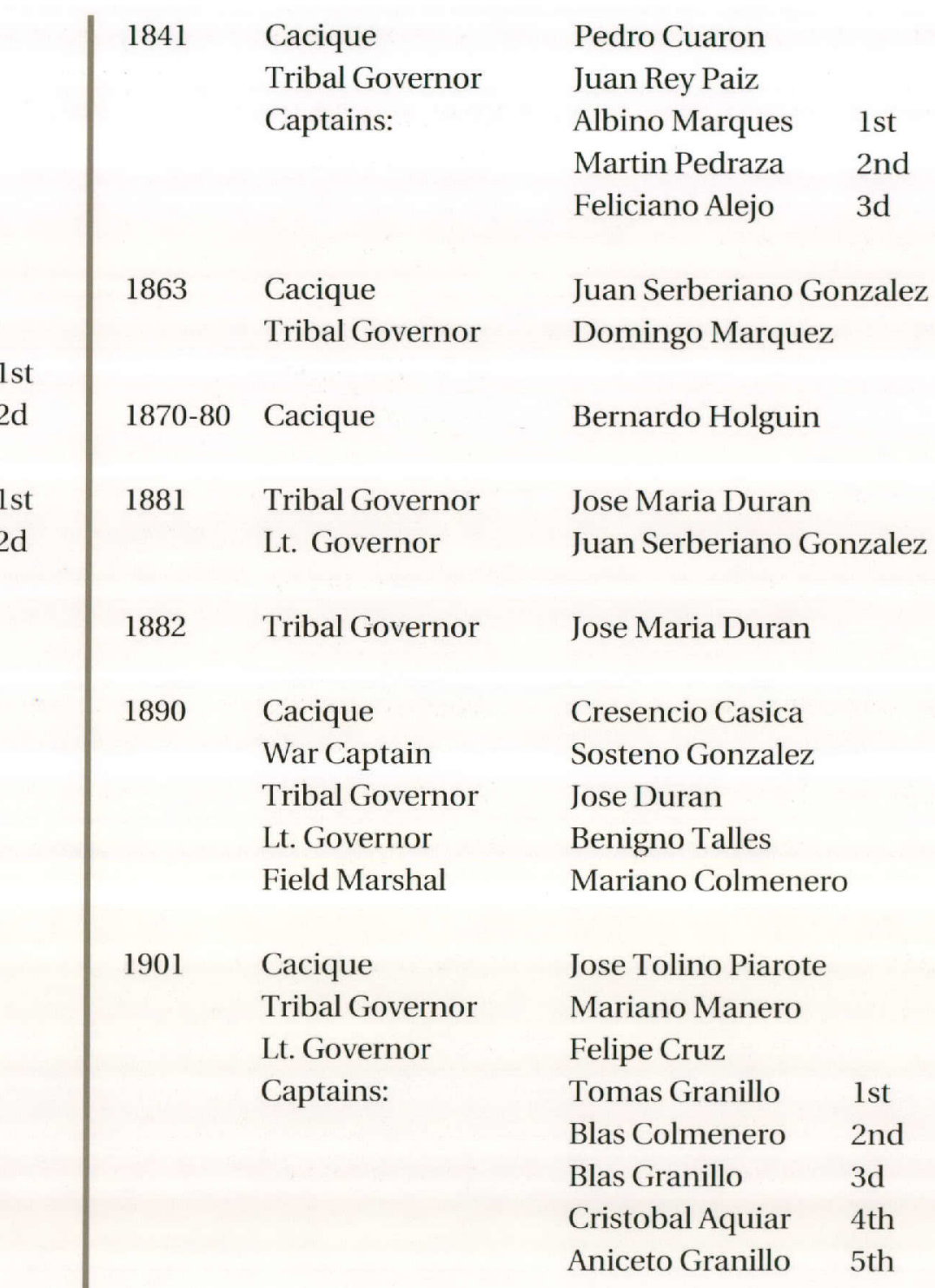




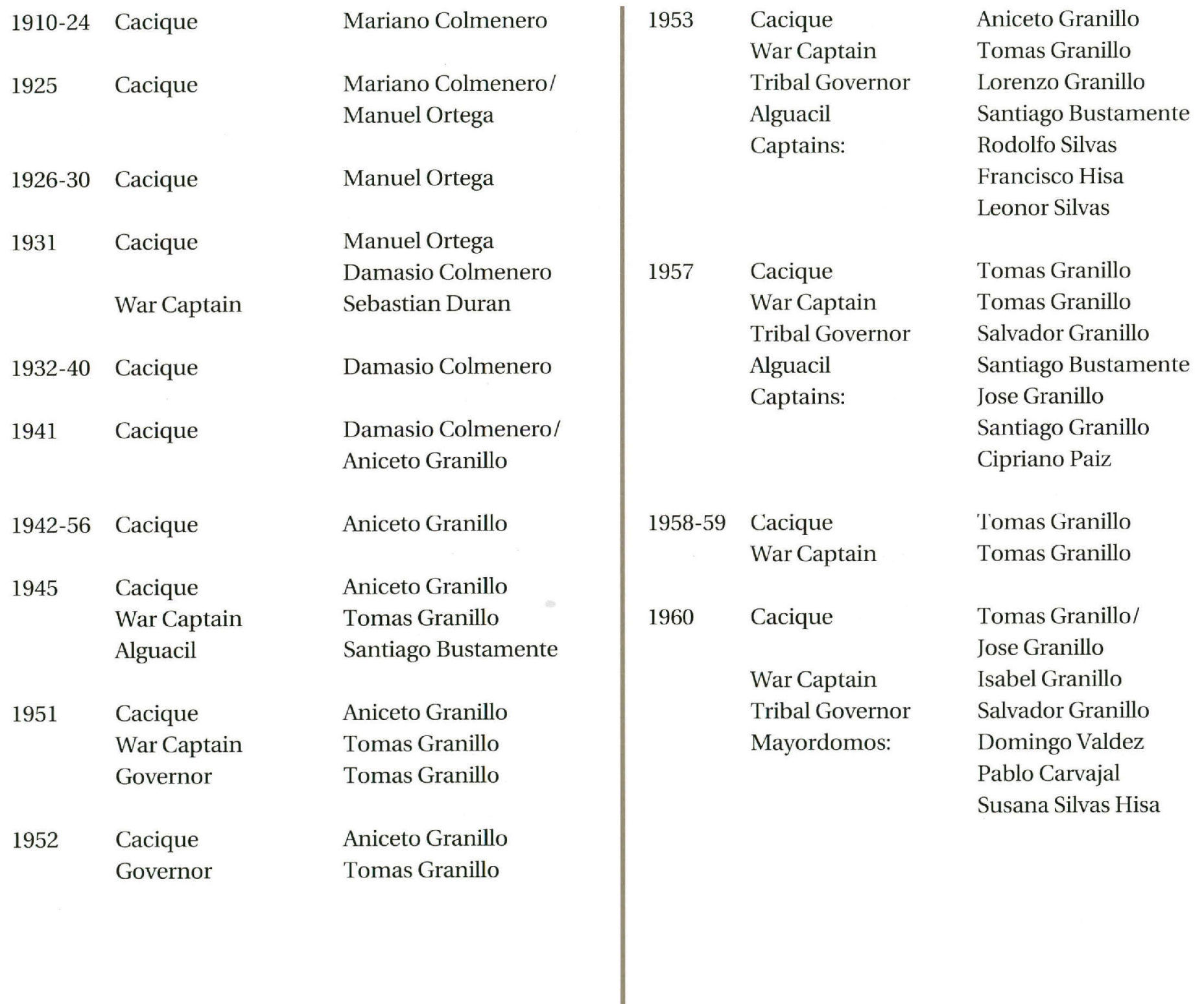




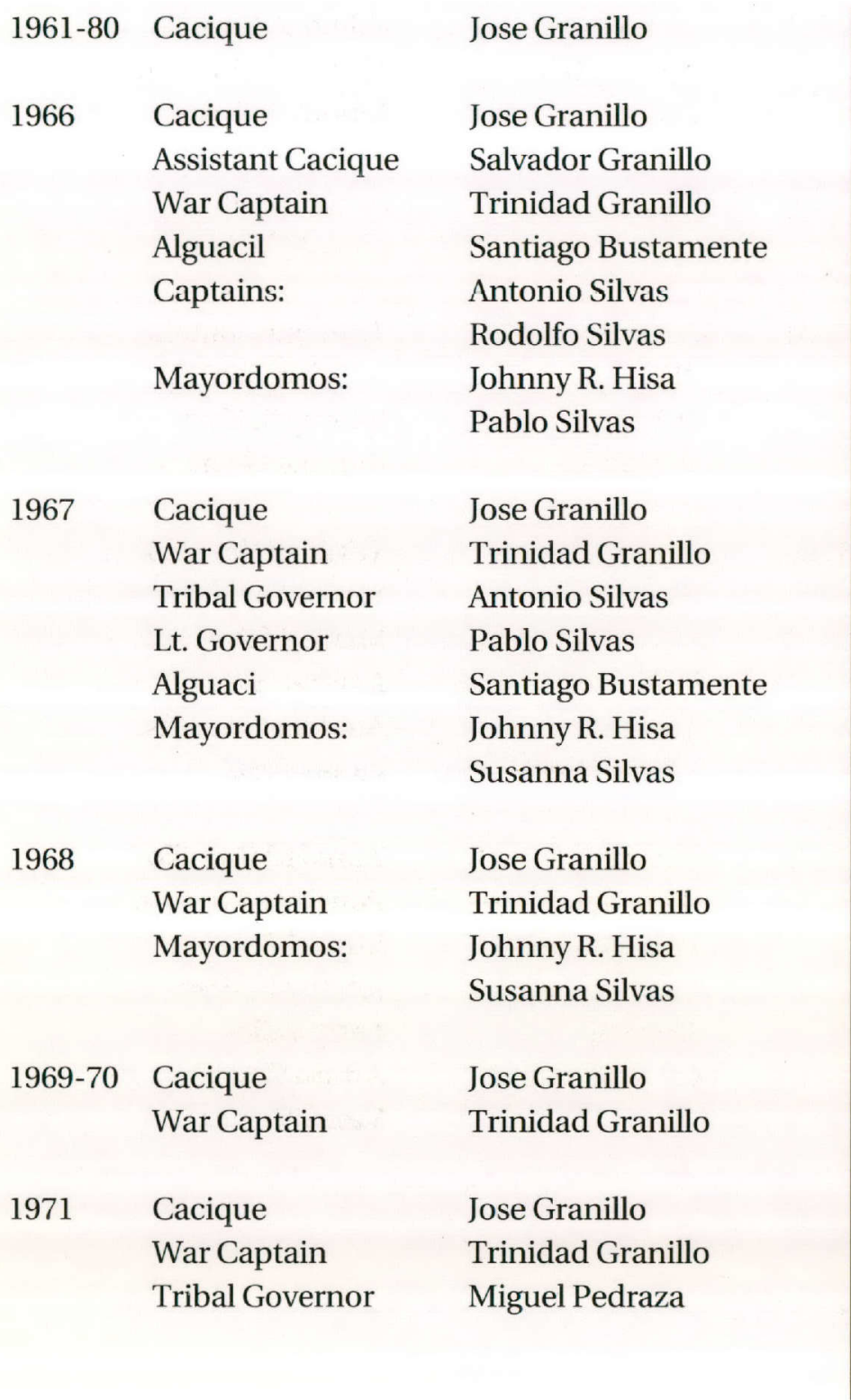

\begin{tabular}{|c|c|c|}
\hline 1972 & $\begin{array}{l}\text { Cacique } \\
\text { Tribal Governor }\end{array}$ & $\begin{array}{l}\text { Jose Granillo } \\
\text { Miguel Pedraza }\end{array}$ \\
\hline 1973 & $\begin{array}{l}\text { Cacique } \\
\text { War Captain } \\
\text { Tribal Governor } \\
\text { Alguacil }\end{array}$ & $\begin{array}{l}\text { Jose Granillo } \\
\text { Trinidad Granillo } \\
\text { Pablo Silvas } \\
\text { Joe Sierra }\end{array}$ \\
\hline 1974 & $\begin{array}{l}\text { Cacique } \\
\text { War Captain } \\
\text { Alguacil }\end{array}$ & $\begin{array}{l}\text { Jose Granillo } \\
\text { Trinidad Granillo } \\
\text { Joe Sierra }\end{array}$ \\
\hline 1975 & $\begin{array}{l}\text { Cacique } \\
\text { War Captain } \\
\text { Councilman }\end{array}$ & $\begin{array}{l}\text { Jose Granillo } \\
\text { Trinidad Granillo } \\
\text { Miguel Pedraza }\end{array}$ \\
\hline 1976 & $\begin{array}{l}\text { Cacique } \\
\text { War Captain } \\
\text { Tribal Governor } \\
\text { Lt. Governor } \\
\text { Alguacil } \\
\text { Councilmen: }\end{array}$ & $\begin{array}{l}\text { Jose Granillo } \\
\text { Trinidad Granillo } \\
\text { Joe Sierra } \\
\text { Antonio Silvas } \\
\text { Pablo Silvas } \\
\text { Miguel Pedraza Jr. } \\
\text { Trinidad Granillo Jr. }\end{array}$ \\
\hline 1977 & $\begin{array}{l}\text { Cacique } \\
\text { War Captain } \\
\text { Tribal Governor } \\
\text { Lt. Governor } \\
\text { Alguacil } \\
\text { Councilmen: }\end{array}$ & $\begin{array}{l}\text { Jose Granillo } \\
\text { Trinidad Granillo Sr. } \\
\text { Joe Sierra } \\
\text { Antonio Silvas Sr. } \\
\text { Trinidad Granillo Jr. } \\
\text { Pablo Silvas } \\
\text { Miguel Pedraza Jr. }\end{array}$ \\
\hline
\end{tabular}




\begin{tabular}{|c|c|c|c|c|c|}
\hline 1978 & $\begin{array}{l}\text { Cacique } \\
\text { War Captain } \\
\text { Tribal Governor } \\
\text { Lt. Governor } \\
\text { Alguacil }\end{array}$ & $\begin{array}{l}\text { Jose Granillo } \\
\text { Trinidad Granillo } \\
\text { Joe Sierra } \\
\text { Antonio Silvas } \\
\text { Pablo Silvas }\end{array}$ & 1983 & $\begin{array}{l}\text { Cacique } \\
\text { War Captain } \\
\text { Tribal Governor } \\
\text { Lt. Governor } \\
\text { Alguacil } \\
\text { Councilman }\end{array}$ & $\begin{array}{l}\text { Trinidad Granillo } \\
\text { Miguel Pedraza Jr. } \\
\text { Johnny R. Hisa } \\
\text { Antonio Silvas Jr. } \\
\text { Arturo Gomez } \\
\text { Vicente Munoz Jr. }\end{array}$ \\
\hline 1979 & $\begin{array}{l}\text { Cacique } \\
\text { War Captain } \\
\text { Tribal Governor } \\
\text { Lt. Governor } \\
\text { Alguacil }\end{array}$ & $\begin{array}{l}\text { Jose Granillo } \\
\text { Trinidad Granillo } \\
\text { Antonio Silvas Sr. } \\
\text { Armando Ortiz } \\
\text { Pablo Silvas }\end{array}$ & 1984 & $\begin{array}{l}\text { Cacique } \\
\text { War Captain } \\
\text { Tribal Governor } \\
\text { Lt. Governor }\end{array}$ & $\begin{array}{l}\text { Trinidad Granillo } \\
\text { Antonio Granillo } \\
\text { Johnny R. Hisa } \\
\text { Antonio Silvas }\end{array}$ \\
\hline 1980 & $\begin{array}{l}\text { Cacique } \\
\text { War Captain } \\
\text { Tribal Governor } \\
\text { Lt. Governor } \\
\text { Alguacil }\end{array}$ & $\begin{array}{l}\text { Jose Granillo } \\
\text { Trinidad Granillo } \\
\text { Antonio Silvas Sr. } \\
\text { Armando Ortiz } \\
\text { Pablo Silvas Sr. }\end{array}$ & 1985 & $\begin{array}{l}\text { Cacique } \\
\text { War Captain } \\
\text { Tribal Governor } \\
\text { Lt. Governor } \\
\text { Alguacil } \\
\text { Councilman }\end{array}$ & $\begin{array}{l}\text { Trinidad Granillo } \\
\text { Santos Sanchez } \\
\text { Manuel Silvas } \\
\text { Antonio Silvas } \\
\text { Antonio Granillo } \\
\text { Lionel Paiz }\end{array}$ \\
\hline 1981 & $\begin{array}{l}\text { Cacique } \\
\text { War Captain } \\
\text { Tribal Governor }\end{array}$ & $\begin{array}{l}\text { Trinidad Granillo } \\
\text { Trinidad Granillo Jr. } \\
\text { Antonio Silvas Sr. }\end{array}$ & 1986 & $\begin{array}{l}\text { Cacique } \\
\text { War Captain } \\
\text { Tribal Governor }\end{array}$ & $\begin{array}{l}\text { Trinidad Granillo } \\
\text { Ponciano Holguin } \\
\text { Miguel Pedraza }\end{array}$ \\
\hline 1982 & $\begin{array}{l}\text { Cacique } \\
\text { War Captain } \\
\text { Tribal Governor } \\
\text { Lt. Governor } \\
\text { Alguacil }\end{array}$ & $\begin{array}{l}\text { Trinidad Granillo } \\
\text { Miguel Pedraza } \\
\text { Johnny R. Hisa } \\
\text { Antonio Silvas Jr. } \\
\text { Arturo Gomez }\end{array}$ & & $\begin{array}{l}\text { Lt. Governor } \\
\text { Alguacil } \\
\text { Councilmen: }\end{array}$ & $\begin{array}{l}\text { Johnny R. Hisa } \\
\text { Larry Valles } \\
\text { Arturo Gomez } \\
\text { Vince Munoz }\end{array}$ \\
\hline
\end{tabular}




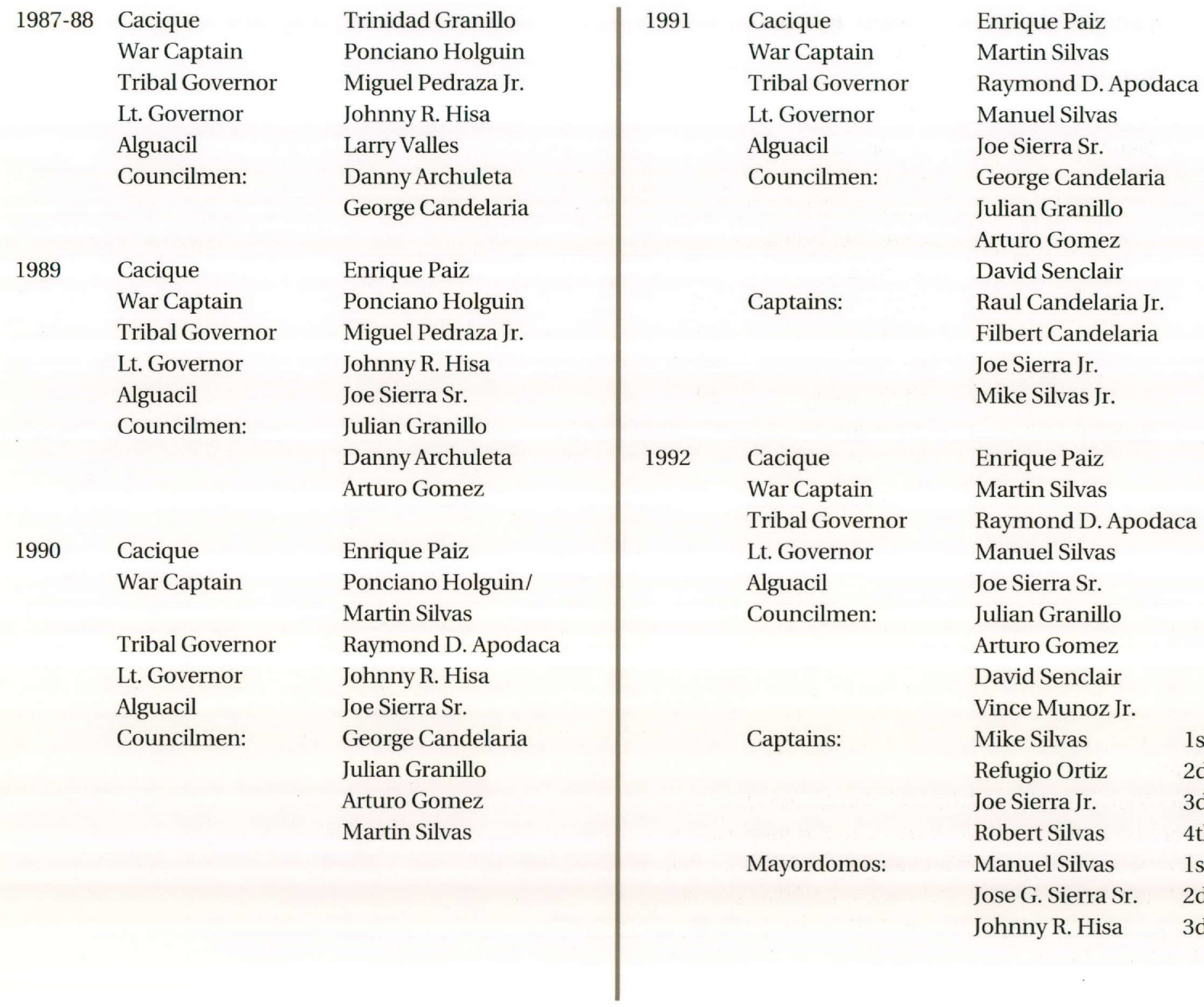




$\begin{array}{lll}\text { Cacique } & \text { Enrique Paiz } & \\ \text { War Captain } & \text { Martin Silvas } & \\ \text { Tribal Governor } & \text { Julian Granillo } & \\ \text { Lt. Governor } & \text { Manuel Silvas } & \\ \text { Alguacil } & \text { Joe Sierra } & \\ \text { Councilmen: } & \text { Arturo Gomez } & \\ & \text { Raul Candelaria Jr. } \\ & \text { George Candelaria } & \\ & \text { Rudy Cruz } & \\ \text { Captains: } & \text { Refugio Ortiz } & 1 \text { st } \\ & \text { Robert Silvas } & 2 \mathrm{~d} \\ & \text { Joe Sierra Jr. } & 3 \mathrm{~d} \\ & \text { Chris Silvas } & 4 \text { th } \\ \text { Mayordomos: } & \text { Alicia Ruiz } & 1 \mathrm{st} \\ & \text { Herminia Silvas } & 2 \mathrm{~d} \\ & \text { Tony Cruz } & 3 \mathrm{~d}\end{array}$

SOURCES:

The Tigua Indians of Ysleta del Sur Pueblo, Texas: Historic Pueblo Immigrants from New Mexico (a report prepared for the Native American Rights Fund, Boulder, Colorado, 1985), pg. 38. Other sources include Debbie Martin (in a personal communication), tribal records, The El Paso Herald-Post, and The El Paso Times. 

Baked the color of sand

and fitted with hemp, it holds

rainfall. It is carried over the adobe

land and hung against sandcolored walls, inside or out, while the sun heats

water to sand, and the sky

thrums overhead, endless

and deep, a great exhalation of breath.

When I run my hand along the once-green

skin, I can feel it breathe. I can

feel sky running through its veins.

When I drink from its heart

and eat the bread baked in the smooth

clay ovens that rise here

like temples, I can taste sunlight ground against sand-colored rock and saltwater flaked from dried

oceans, where men and women formed

a ragged line from the Bering Strait

pulled by a god for whom they had no nameeach night along the way must have been

like no other, a grain of rest

inside the dome of firelight.
Here the very fields know how to wait.

They flare green when they can.

They subside and flare green again

the way this brown fruit holds rain

for months in its fortress shell

until a man's or woman's hands

lift it into use, sand-colored hands

with sand in their creases.

They offer water to the land, they

shape the land into bricks and tilt more

water to their faces, containers of silence

warmed to fine leather from looking

at sky, looking down at sand, looking

at sky again.

Leslie Ullman

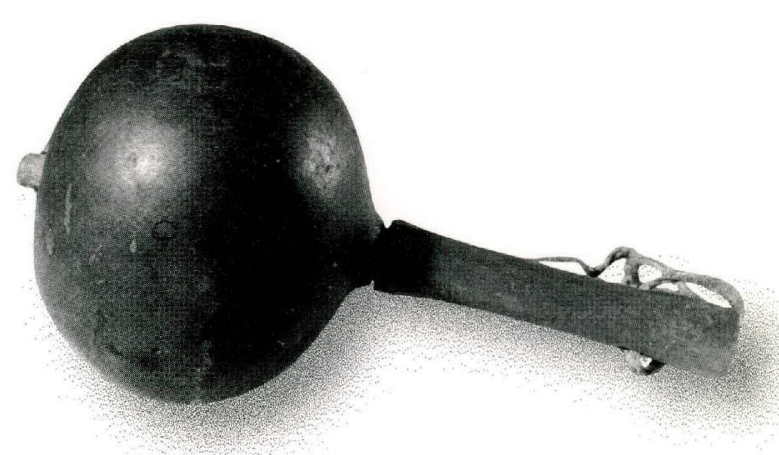



${ }^{1}$ Esteban, or Estebanico of Azemour as he is more accurately called, played a more important role in the exploration of America than previously recognized. Anthropologist Nicholas Houser observes: “Estebanico's cultural (Moroccan) behavior reflected a tribal sense of community and native healing skills, in addition to his affable personality, linguistic abilities, and keen intelligence, which resulted in his immediate acceptance among Native Americans. This is in contrast to the three Europeans (Andres Dorantes, Alonso Castillo, and Cabeza de Vaca) who were reluctant healers and maintained an aloof presence among the Indians. Estebanico's use of colorful adornments (feathers and jewelry) and his two greyhound dogs (which later accompanied him to Zuni) strongly suggest that he recognized the Islamic concept of bakara (a property of holiness or state of grace which affords protection)." Nicholas Houser, "Estebanico of Azemour" (Prepared for the XII Travelers Memorial of the Southwest, An Official Project of the United States Columbus Quincentenary 1 July 1992). Also see Cabeza de Vaca's, Adventures in the Unknown Interior of America, Cyclone Covey, ed. and trans. (University of New Mexico Press, 1988), 65.

${ }^{2}$ The Southwest was linked to Mesoamerica by a series of trails that served as trade routes. For further evidence of the interaction between the cultural groups of North America, see: Carroll L. Riley and Joni L. Manson, "The Cibola-Tiguex Route: Continuity and Change in the Southwest," New Mexico Historical Review 58 (1983): 347.

${ }^{3}$ For further reading about the prehistory of North America, see David J. Meltzer, "Why don't we know when the first people came to North America," American Antiquity 54 (1989) by the Society for American Archaeology. Also Linda S. Cordell, Prehistory of the Southwest (New World archaeological record) (Academic Press, Inc., 1984). Other sources are: Stuart J. Fiedel, Prehistory of the Americas (Cambridge University Press, 1987); Brian M. Fagan, The Great Journey. The peopling of ancient
America (Thames and Hudson, 1987), and Carroll L. Riley, The Frontier People. The Greater Southwest in the Protohistoric Period (University of New Mexico Press, 1987).

4 Castañeda's history of the expedition, narrating the expedition to Cibola, undertaken in 1540, describes all those settlements, ceremonies and customs. Pedro de Castañeda of Naxera, Narratives of the Coronado Expedition, Coronado Historical Series, vol. 2, eds. and trans., George P. Hammond and Agapito Rey (University of New Mexico Press, 1940), 254.

${ }^{5}$ George P. Hammond and Agapito Rey, The Rediscovery of New Mexico 1580-1594 (University of New Mexico Press, 1966), 84-86. From the Gallegos' Relation of the Chamuscado-Rodríguez Expedition.

${ }^{6}$ Ibid., 84.

7 Ibid., 85 .

${ }^{8}$ Ibid., 86.

${ }_{9}$ Because the Rio Grande has changed course many times since the arrival of Oñate, the exact position of the celebration might not have been in present Texas. For more information see: Jack Lowry "Gracias a Dios," Texas Highways (April 1992): 18-21.

${ }^{10}$ Each pueblo had a leader whom the Spanish called cacique, or "Indian chief," a term derived from the name of a leader among the Arawak Indians of the West Indies. Eugene O. Porter, "The Spanish Occupation of West Texas and New Mexico," Password, vol. 10, no. 3 (Fall 1965) : 90. The traditional office was retained, though Oñate established civil governments modeled on the Spanish form which allowed more efficient management of the pueblos. He required the tribe to also name a governor (called gobernadorcillo), a lieutenant governor (teniente), after 1700, an office called war captains (called capitanes de guerra), a sheriff (alguacil), mayor-domos (irrigation ditch bosses) and church wardens (sacristanes). William C. Sturtevant, ed., Handbook of North American Indians, vol. 9, Smithsonian Institution (Washington, D.C., 1979), 178-93. 
${ }^{11}$ Elsie Clews Parsons, The Pueblo of Isleta, Indian Classics Series vol. 1 (University of Albuquerque, 1974), 203. Other studies of the abandonment cite deterioration of agricultural conditions (Steen 1977) and Lummis (1966), 307-08

12 This summary taken from: Vina Walz, "History of the El Paso Area, 1680-1692,” (diss., University of New Mexico, 1951), 65-67.

${ }^{13}$ Dr. W.H. Timmons, "The Spanish Census of Ysleta in 1790 - With a List of the Tiguas," Password, vol. 37, no. 3 (Fall 1992) : 137.

${ }_{14}$ Walz, History of the El Paso Area, 1680-1692, 305.

${ }_{15}$ Manuel J. Espinoza, "First Expedition of Vargas into New Mexico, 1692," Coronado Cuarto Centennial Publications, vol. 10 (University of New Mexico Press, 1940). Some investigations show that the Indians of Ysleta del Sur did not return to their former home. See Eleanor B. Adams and Fray Angelico Chavez, The Missions of New Mexico, 1776: A descrip tion by Fray Francisco Atanasio Dominguez, with Other Contemporary Documents (University of New Mexico Press, 1956): 203. From Myra Jenkins, History and Administration of the Tigua Indians of Ysleta del Sur During the Spanish Colonial Period, 42.

16 Kino's map from Ernest Burrus, Kino and the Cartography of Northeastern New Spain, plate XIII (facing page 50), Bibliotheque

Nationale, Paris (D'Anville collection, Arizona Pioneers Historical Society, Tucson, Arizona)

${ }_{17}$ Myra Ellen Jenkins,"History and Administration of the Tigua Indian of Ysleta del Sur During the Spanish Colonial Period," Aboriginal Use and Occupation by Tigua, Manso, And Suma Indians, ed. Rex E. Gerald (Garland Publishing, Inc., New York and London, 1974), 213-76. Jenkins quotes Vito Alessio Robles, ed., Diario y Derretero de la Caminado, Visto y Observado en la Visita que hizo a los Presidios de la Nueva España Septentrional el Brigadier Pedro de Rivera (Taller Autogrâfico, Mexico, D. F., 1946), 47. Also David Agee Horn, ed., American Indian Ethnohistory,
Indians of the Southwest (Garland Publishing, Inc., New York and London, 1974), 257.

${ }_{18}$ Charles Wilson Hackett, ed., Historical Documents relating to New Mexico, Nueva Vizcaya, and Approaches thereto to 1773, vol. 3 (Carnegie Institution, Washington, D. C., 1937), 377. This information from Jenkins, "History and Administration," 42-43.

${ }^{19}$ Eleanor B. Adams, ed., “Bishop Tamarõn's Visitation of New Mexico, 1760," Publications in History, vol. 15 (University of New Mexico, February 1954).

${ }^{20}$ Dr. W. H. Timmons, "The Spanish Census of Ysleta in 1790," 138

${ }^{21}$ For additional information on the land ownership disputes see Alan Minter, "The Tigua Indians of the Pueblo of Ysleta del Sur," West Texas Historical Association Year Book (1969), 30. Also Charles H. Lange, Carroll L. Riley and Elizabeth M. Lang, eds., The Southwestern Journals of Adolph Bandelier 1889-1892 (University of New Mexico Press, 1984), 404-5. In addition an excellent work is Leon Metz's Border: the U.S.-Mexico Line (Mangan Books, El Paso, 1989). Also J. J. Bowden, Spanish and Mexican Land Grants in the Chihuahuan Acquisition (Texas Western Press, 1971). The history of the adjacent Socorro grant contains much information about Ysleta: Katherine H. White, The Pueblo de Socorro Grant (Katherine Hope Huffman White Memorial Trust, El Paso,1986).

22 This interesting episode in the history of the Tiguas and El Paso is detailed in C. L. Sonnichsen's book, The El Paso Salt War of 1877 (Texas Western Press, 1961).

${ }^{23}$ For Texas Ranger Gillett's full account of the battle and other stories see James B. Gillett, Six Years with The Texas Rangers, 1875 to 1881 (University of Nebraska Press, 1976).

${ }^{24}$ Lansing B. Bloom, ed., Bourke on the Southwest, vol. 13 (New Mexico Historical Review 1938), 205. From Rex E. Gerald, The Tigua Indians of Ysleta del Sur, Texas: Historic Pueblo Immigrants from New Mexico, 16. 
${ }^{25}$ Herman F. C. Ten Kate, Jr., Reizen en Onderzoekingen in NoordAmerika [Travels and Researches in North America] (E. J. Brill, Leiden, The Netherlands, 1885).

${ }^{26}$ For more information regarding the Indian population in Tortugas and the Tigua rabbit hunt refer to the monograph by Patrick $H$. Beckett and Terry L. Corbett, Tortugas, monograph no. 8 (COAS Publishing and Research, Las Cruces, 1990).

${ }^{27}$ Nancy Hamilton, in a personal communication, reported: “In 1974, I interviewed Miguel Pedraza and Alton Griffin about the Márquez family while doing a study of the first mayor of El Paso, who was married to a Tigua woman named Márquez. (Nancy Hamilton, Ben Dowell, El Paso's First Mayor, Texas Western Press, Southwestern Studies Monograph no. 49, 1976). I was told that there were no longer any Márquezes on the Tigua rolls, but they lived in Zaragosa. A descendant of Juana Márquez Dowell and I visited a store facing the square in old Zaragosa (not the part by the border crossing) whose proprietor, Ramón Márquez, strongly resembled photos of Juana." She also reported that a grandson of Juana's John Newton Phillips, wrote a ms., unpublished and undated, which is in the University of Texas Archives, Historical Manuscript Collections, No. 1687. In it, he describes an interview with Manuel Ortega who told him that two nineteenth century caciques were named Márquez, 'El Chapo' Alvino Márquez, after whose death certain tribal papers regarding a government land grant could not be found, and José Domingo Márquez, who, after the Rio Grande boundary was established which divided the Tiguas' Spanish land grant between Mexico and the United States, led his people to the Mexican side and founded the village of Zaragosa about 1862."

${ }^{28}$ For more information on the priest dispute, see Sister M. Lilliana Owens, Carlos M. Pinto, S.J., Apostle of El Paso (Revista Catolica Press, 1951), 47.
${ }^{29}$ Ernest J. Burrus, Outstanding Historical Dates and Events of the Towns, Missions and Churches in the El Paso Valley (Historical Cultural Commision of the Catholic Diocese of El Paso, Texas, 1981). Burrus notes, "The mission caught fire from a pan of burning coals left by a careless sacristan as the Ysletans were preparing to celebrate the Feast of San Isidro" (15 May ). Cleofas Calleros attributes the blaze to accidenta ignition of chemicals.

${ }^{30}$ Cleofas Calleros, Tigua Indians, in collaboration with Marjorie F. Graham (El Paso, Texas, 1953), 15.

${ }^{31}$ For additional bibliographical information, see Bill Wright, Preliminary Bibliographic Information Regarding the Tigua Indians of Ysleta del Sur (Special Collections, University of Texas at El Paso Library, 1992). 



\section{Notes on Historic Photographs}

${ }^{1}$ Source: Arizona State Museum, University of Arizona, accession number 13495. "Abuelo dancers with two Tigua girls. Until some time before 1920 the Abuelo Dance, also called the Turtle Dance (Baile de Tortuga), was danced by two masked men on Christmas afternoon. The buffalo hide masks shown here were still in the tribal kiva or tusla in the 1970 's. Photography by an unknown photographer, probably December 25, about 1912. The girls are Juanita Holguin and Ramona Paiz." Quoted from Nicholas P. Houser, Handbook of North American Indians, vol. 9, William C. Sturtevant, ed. Smithsonian Institution, Washington, D.C., 1979, 339 .

${ }^{2}$ Source: Thomas Branigan Memorial Library, Rio Grande Historical Collections, New Mexico State University Library, ca. 1880. Accession no. A76-157/63.

${ }^{3}$ Archivo General de Indias, Guadalajara 139, Document 4. Land Grant signed by Don Diego de Vargas Zapata Luján Ponce de León, Governor of the Kingdom of Nuevo México. 19 May 1692. Photostatic copy in the U.S. Library of Congress 6135-6143.

${ }^{4}$ Source: Otis A. Aultman Collection, El Paso Public Library, accession no. 1376. Photograph dated 1880. Nestora Piarote is a distant relative of former Tigua Governor Joe Sierra. More information on Nestora's pottery and the other ceramic traditions of Ysleta del Sur may be found in a paper by John A. Hedrick, "Investigations of Tigua Potters and Pottery at Ysleta del Sur, Texas," in the El Paso Archaeological Society's Publication, The Artifact, vol. 9 no. 2 (1971). The Alderete-Candelaria house today serves as an example of Mexican American rural vernacular adobe architecture typical of the West Texas border region. Originally constructed between 1875 and 1877, it consisted of adobe walls without foundation, dirt floors, an enlarged entry to the courtyard and a roof made of dirt supported by round beams, smaller cross poles and dried plants. The Tigua Indian Tribe owns the building. See El Paso Times, Saturday, 8 December 1984 for more information. Also an article by Herbert C. Morrow, "The Study of an Adobe Building in Ysleta, Texas: The Alderete-Candelaria House," The Artifact, vol.16 no. 3 (1978).

${ }^{5}$ Source: Otis A. Aultman Collection, El Paso Public Library, accession no. A5898. Even though Fewkes in 1907 noted that the Ysleta pueblo was single story, the possibility exists that this image was made ca. 1870 and Fewkes was correct in his observation because of changes that occurred in the interim. It is possible that the buildings were located at the site of the present-day Ysleta Health Clinic on old Pueblo Road, which was excavated by Batcho and Kaufman Associates in 1991. The woman with the pot has been identified by Johnny Hisa as his great-great-grandmother, Nestora Piarote, the original photograph having been returned to his family by relatives in Isleta, New Mexico. A copy was made by Aultman and placed in his collection sometime in the early 1900s.

${ }^{6}$ Source: Miguel Pedraza, Wright photo collection no. 873116. Granillo was later killed in a shootout in the sandhills with the Texas Rangers in an alleged dispute over a woman, ca.1880.

${ }^{7}$ Nancy Hamilton details the marriage of Juana and Ben Dowell in her monograph, Ben Dowell, El Paso's First Mayor, Texas Western Press, 1976, Monograph no. 49, 11. Drawing by Norman Booty.

${ }^{8}$ Source: Special Collection, United States Military Academy Library. Sketch dated 11 November 1881.

9 Source: Otis A. Aultman archive, El Paso Public Library. Photograph dated ca. 1880.

${ }^{10}$ Source: Rose Hernandez from a family tintype ca. 1892.

${ }^{11}$ Source of Herman F.C. Ten Kate artifact photos: Rijksmuseum Voor Volkenkunde, Leiden, Netherlands. For more information surrounding the search for these artifacts see: Robert Moore, "Lost Tigua artifacts found in Netherlands," El Paso Times, 23 February 1990, p. 1A.

${ }^{12}$ Ibid. 
${ }^{13}$ Ibid.

${ }^{14}$ Ibid.

15 Source: Arizona State Museum, University of Arizona catalog no. 13496. Celebrants at the Feast Day of St. Anthony, in front of the old Ysleta del Sur church, ca. 1898. The man before the door of the Ysleta Mission Church is Mariano Colmenero, who at the time was governor of the tribe. He served as an Indian scout in the United States Army during the campaigns against renegade Apache Indians, including Victorio's band. In fact, many men in this photograph served as Indian scouts for both the Texas Rangers and the United States Army. To his right, with feather headdress, is José Tolino Piarote, then the cacique. To the left of Mariano is Manuel Ortega. The men in the front of each line, Vicente Paiz and Teodoro Pedraza, are Piro Indians from the Mexican side of the Rio Grande. They had resided in Senecu which today is part of Ciudad Juárez. Piro Indians from Senecu, Mexico, and Socorro, Texas, frequently participated in the social affairs of the Ysleta Indians because of family relationships and of the common Indian affiliation. The Piro man at the right has an elaborate headdress with feathers and what are probably carriage mirrors. He holds a bow and arrow which is still used in the traditional Tigua dances. Tigua men and boys hold a bow and arrow in one hand and a gourd in the other when dancing. Today the bows and arrows are merely representations and could never serve in hunting. The buckskin jackets worn by some of the men are decorated with fringe and beadwork and probably medals received during military service. The tribal drum is held by the man in the center of the picture. Less than ten years after this photograph was taken, the old Ysleta church was destroyed by fire (1907)

${ }^{16}$ Source: Institute of Texan Cultures, No. 71-382, Date 1916, From Calleros Estate, c/o Mrs. Cleofas Calleros, El Paso, Texas.

17 Source: David Sinclair, ca. 1915. Wright Collection no. 911228A.
${ }^{18}$ Source: Arizona State Museum, University of Arizona, catalog no. 13494. Date: July 1914. Ramona's uncle served as an Indian scout for the U.S. cavalry during the Apache campaigns in Texas.

${ }^{19}$ Source: Manny Rodela. Date: ca. 1930. The trailer was a mobile maternity clinic used for delivering babies. Dr. Love charged nineteen dollars for delivery and ten dollars for the use of the trailer. He delivered approximately fifty babies a month and he covered territory from Fort Hancock, Texas, to Deming and Cloudcroft, New Mexico.

${ }^{20}$ Source: Rosemary Hisa, ca. 1930. Other sources cite the battle as between the Kiowa and the Mexicans or the Apaches; however, Tigua oral tradition is explicit. Archaeologist W. W. Newcomb, Jr., The Rock Art of Texas Indians, University of Texas Press, 1967, p. 202, believes the Pueblo Indians were not permanent residents of the Hueco Tanks area but utilized the natural water and used the caves for shrines where prayers and rituals were performed from time to time. The remainder of the paintings at Hueco Tanks were thought to be the work of the Mescalero Apache. Some authorities identify the drawings above as Tigua representations of a famous battle with the Kiowas. Another account of the Kiowa battle and the meaning of the cave art can be found in LaVan Martineau's book, The Rocks Begin To Speak, KC Publications Las Vegas, p. 73-82. Wright Collection no. 870813

${ }^{21}$ Source: Arizona State Museum, University of Arizona, catalog no. 13493.

${ }^{22}$ Source: Institute of Texan Cultures, San Antonio, No. 71-370, Calleros Estate, c/o Mrs. Cleofas Calleros, El Paso, Texas. Date: 1936.

${ }^{23}$ Source: Institute of Texan Cultures, San Antonio, No. 71-375,

Calleros Estate, c/o Mrs. Cleofas Calleros, El Paso, Texas. Date: 12 June 1936.

${ }^{24}$ Source: Rosemary Silvas. Wright Collection no. 870812. Hueco Tanks, July 1959. Cantona Silvas (with drum), Rosalia Granillo (chief's 
wife, non-Indian), Tomas Silvas top right, Guillermo Silvas below right, Mike Silvas bottom center, Ramon Carbajal left bottom right, and Isabel Silvas left bottom left.

25 Source: Miguel Pedraza. Date: 16 May, 1941. Photographer: A.J. Slogeris. Wright Coilection no. 873110.

${ }^{26}$ Source: Nicholas Houser. Date: 1966. Houser reports that Juanita related to him that in her youth the Tigua drum could be heard plainly in Senecu Pueblo, three miles up the river from Ysleta on the Mexican side. Wright Collection no. 881011.

27 Source: Tom Diamond. Photographer: Lee Cain. Date: 1963. This photograph was taken for Tom Diamond when he was attempting to establish a basis for federal and state recognition. Wright Collection no. 882005 .

${ }^{28}$ Source: Herminia Silvas. Date: ca.1969. Wright Collection no. 870829.

29 Source: Leonard G. Garcia. Bicentennial celebration in Dallas 3 July 1968. Informants report that the uniforms and the chief's headdress were provided by Cleofas Calleros. Wright Collection no. 872824.

${ }^{30}$ Source: Tigua Pueblo Administration. Date: ca.1980. Wright Collection no. 911109

${ }_{31}$ Source: Ysleta Pueblo Administration. Date: ca.1983. Wright Collection no. 911010A.

32 Source: Ray Apodaca. Date: 1990. Wright Collection no. 911216A.

${ }^{33}$ Source: Smithsonian Institution. Second annual Festival of American Folklife, 1968. Photographer: Robert Yellin. Accession no. 78-9016-16A. Also see “Tiguas Taking Part in Folk Festival," El Paso Times, 3 July 1968, and "Tiguas in Washington," El Paso Times, 6 July 1968.

${ }_{34}$ Source: Smithsonian Institution. 1968 Festival of American Folklife. Photographer: Robert Yellin. Accession no. 78-9046-9A.

${ }^{35}$ Source: Collection of Joe Sierra. Date: 1988. Wright collection 911216A (original in color).
${ }^{36}$ Source: Bill Wright Photography Collection, negative number 93-511. Julian Granillo in front of the Tigua administration office. He was elected in 1993. 

